INTERDISCIPLINARY STUDIES IN PERFORMANCE 12

Janina Falkowska / Krzysztof Loska (eds.)

\title{
Conflict and Controversy in Small Cinemas
}

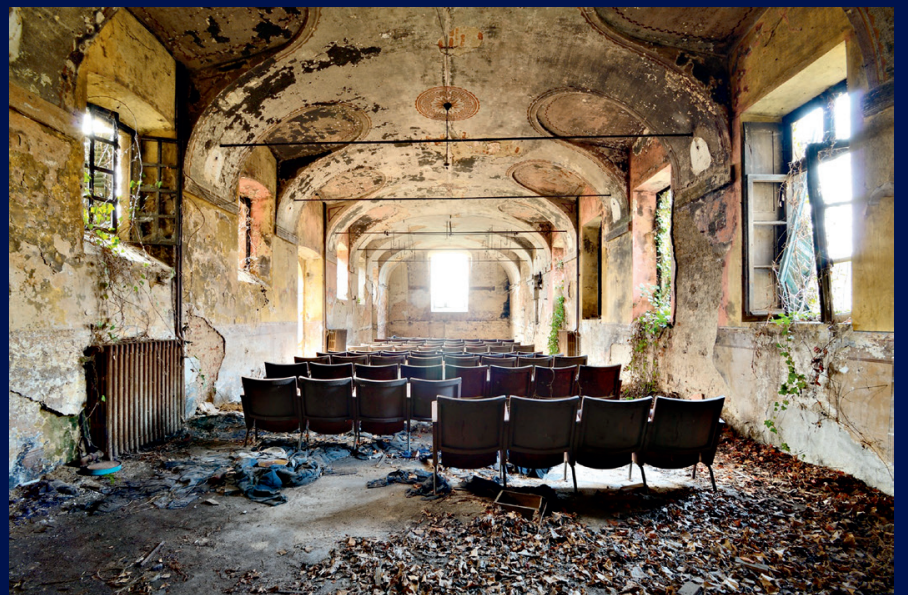

\section{(10)


Janina Falkowska / Krzysztof Loska (eds.)

\section{Conflict and Controversy in Small Cinemas}

This book examines small cinemas and their presentation of society in times of crisis and conflict from an interdisciplinary and intercultural point of view. The authors concentrate on economic, social and political challenges and point to new phenomena which have been exposed by film directors. They present essays on, among others, Basque cinema; gendered controversies in post-communist small cinemas in Slovakia and Czech Republic; ethnic stereotypes in the works of Polish filmmakers; stereotypical representation of women in Japanese avant-garde; post-communist political myths in Hungary; the separatist movements of Catalonia; people in diasporas and during migrations. In view of these timely topics, the book touches on the most serious social and political problems. The films discussed provide an excellent platform for enhancing debates on politics, gender, migration and new aesthetics in cinema at departments of history, sociology, literature and film.

\section{The Author}

Janina Falkowska is a retired professor from the University of Western Ontario in London, Ontario (Canada) and Professor at the University of Economics and Humanities (WSEH) in Bielsko-Biala (Poland). She specializes in East-Central European and Western European cinemas and has published extensively on Polish and East-Central European cinemas in journals and books related to Eastern and Central Europe. She has initiated a series of conferences about small cinemas in Europe and organized workshops and conferences on European cinemas in Canada.

Krzysztof Loska is Professor of Film and Media and the Director of the Institute of Audiovisual Arts at Jagiellonian University in Krakow (Poland). He has written extensively on media, popular culture, film theory and Japanese cinema in various journals and collective works. He is Vice-President of Polish Society for Film and Media Studies, and member of the Editorial Advisory Board of the bi-monthly "Ekrany". 
Conflict and Controversy in Small Cinemas 


\section{INTERDISCIPLINARY STUDIES IN PERFORMANCE HISTORICAL NARRATIVES. THEATER. PUBLIC LIFE}

Edited by Mirosław Kocur

VOL. 12

Zu Qualitätssicherung und Peer Review der vorliegenden Publikation

Die Qualität der in dieser Reihe erscheinenden Arbeiten wird vor der Publikation durch einen externen, von der Herausgeberschaft benannten Gutachter geprüft.
Notes on the quality assurance and peer review of this publication

Prior to publication, the quality of the work published in this series is reviewed by an external referee appointed by the editorship. 
Janina Falkowska / Krzysztof Loska (eds.)

\section{Conflict and Controversy in Small Cinemas}

\section{量 \\ PETER LANG}


Bibliographic Information published by the Deutsche Nationalbibliothek

The Deutsche Nationalbibliothek lists this publication in the Deutsche Nationalbibliografie; detailed bibliographic data is available in the internet at http://dnb.d-nb.de.

Library of Congress Cataloging-in-Publication Data A CIP catalog record for this book has been applied for at the Library of Congress.

This publication was financially supported by the Jagiellonian University of Kraków, Poland.

Cover image: $\odot$ marcobarone / Fotolia.com

ISSN 2364-3919

ISBN 978-3-631-75029-2 (Print)

E-ISBN 978-3-631-75517-4 (E-PDF)

E-ISBN 978-3-631-75518-1 (EPUB)

E-ISBN 978-3-631-75519-8 (MOBI)

DOI 10.3726/ b14031

\section{PETER LANG}
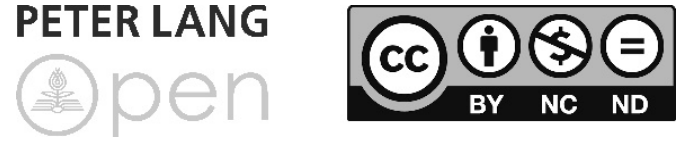

Open Access: This work is licensed under a Creative Commons Attribution Non Commercial No Derivatives 4.0 unported license. To view a copy of this license, visit https://creativecommons.org/licenses/

by-nc-nd/4.0/

(C) Janina Falkowska / Krzysztof Loska (eds.), 2018

Peter Lang GmbH

Internationaler Verlag der Wissenschaften

Berlin 2018

Peter Lang - Berlin · Bern · Bruxelles · New York ·

Oxford $\cdot$ Warszawa $\cdot$ Wien

This publication has been peer reviewed.

www.peterlang.com 


\section{Table of Contents}

Janina Falkowska

Introduction 9

\section{Part 1: Politics in Small Cinemas}

Iwona Kolasińska-Pasterczyk

1. A call for freedom in the Spanish cinema (from a local perspective)

Karolina Kosińska

2. The troubled image: The conflict in Northern Ireland as seen by the Irish and the British

Katixa Agirre

3. Are they terrorists or victims? Basque cinema, violence and memory.

Gorka Etxebarria and Josu Martinez

4. A traditional stereotype for modern Spanish politics: The Basque pro-independence coalition Herri Batasuna and its depiction in cinema ....57

Iratxe Fresneda \& Amaia Nerekan

5. New content and aesthetics in small cinemas: The case of the Basque-language films 80 egunean and Loreak..........................................71

Paulina Cichoń

6. The image of living of local people in the film Timbuktu:

Between the literal and the symbol

\section{Part 2: Gender and Sexuality}

\section{Jana Dudková}

7. Tourists, migrants and travellers:

The role of women in reshaping Slovak (cinematic) identity 101

Katarína Mišíková

8. Reality of corporeality: Female corporeality in recent Slovak social film dramas. 
Sebastian Jagielski

9. Before coming out: Queer representations in contemporary Polish cinema

Bartłomiej Nowak

10. To be or not to be yourself: Turkish diaspora and the foreign land - stereotypes, nation and (hetero)norms

\section{Part 3: Stereotypes and Social Polarities}

Jadwiga Hučková

11. Exposed and concealed Roma conflict: Representation of contemporary

Roma conflicts in Czech Republic, Slovakia, Poland and Hungary

Iwona Grodź

12. Stereotypes and attempts at challenging them in Papusza (2013) by Krzysztof Krauze and Joanna Kos-Krauze.

\section{Part 4: Theory and Small Cinemas}

Krzysztof Loska

13. Migrants and exiles in the films by Katarzyna Klimkiewicz

Agnieszka Kiejziewicz

14. From controversy to contemplation: The thematic areas of the new Japanese avant-garde and experimental film in comparison to the "old masters" of Japanese avant-garde.

Janina Falkowska

15. Mockumentary cinema and its political might: Self-reflexivity and carnivalesque in the films of Michael Moore and Sacha Baron Cohen .... 211

\section{Part 5: Aesthetics of New Small Films}

\section{Phil Mann}

16. De-centered subversion: Hukkle and the challenging of revisionist historiography 
Chris LaLonde

17. "I don't know": Linking past and present, the personal and the nation, and movement in Sterlin Harjo's This May be the Last Time ....................... 235

Ilona Copik

18. Post-industrial landscape in the "Silesian cinema":

Between the aesthetic and cultural experience

245

Marta Stańczyk

19. Once upon a time there used to live a people... Neighborhooders and The Heritage as fairy tales about the Polish "excluded" 



\section{Janina Falkowska}

\section{Introduction}

The book Conflict and Controversy in Small Cinemas explores small cinemas in view of their presentation of the difficult and controversial times we live in today. The authors concentrate on the dysfunctionality of political, economic, and social systems; shifting national identities; the exploitation of women and children; terror and the war on terror; and finally, gender and race stereotypes. These phenomena are studied from the point of view of both interdisciplinary and intercultural studies, social economy, political theory and film studies.

Small, non-commercial cinemas have always had the tenacity and bravery to deal with controversial topics, tackle uncomfortable issues and present them in an uncompromising fashion. Primarily independently funded and not always financed by their governments or big corporations, they can more truthfully address the aforementioned topics compared to Hollywood cinema, which is restricted by its funding policies and political attitudes.

The most distinctive aspect of the book is its timeliness as most chapters deal with controversial and politically loaded subjects and the here and now of lives all over the world in the films that are both frank in content and innovative in aesthetics.

It is worth noting that the two main topics of the book, conflict and controversy, are interpreted in various ways in the selected chapters. The conflicts are not only political in nature as presented in the films (as illustrated in chapters in Part 1), but also they are conflicts between film content and form (as illustrated in chapters in Part 5). Conflicts may be both external and internal, especially in such controversial cases as the presentation of Roma people (in Part 3). Controversies surround the lack of controversy in small avant-garde cinemas; controversies occur in the presentation of gender on the one hand (as analyzed in Part 2) and in the understanding of film genres such as mockumentaries on the other (as discussed in Part 4). We present these areas with full understanding that misunderstanding or hesitation when applying these categories to film analysis may be both annoying and inspiring at the same time.

The chapters we present in the book are first of a kind studies of films that portray events or deal with the facts taking place in the present or in the very recent past. The authors of the chapters point to the new phenomena that have been exposed by film directors. Among the most interesting are the discussions 
on Basque cinema; on gendered controversies in post-communist small cinemas from Slovakia, Czech Republic and Hungary; on ethnic stereotypes in the works of Polish filmmakers; on the stereotypical presentation of women in Japanese avant-garde; on post-communist political myths in Hungary; on the separatist movements of Catalonia; and on people in diasporas and during migrations. Some chapters also deal with the aesthetics of small cinemas, such as the aesthetics in Basque cinema or that of the post-industrial landscape in Silesian cinema.

The book is composed of an introduction and five parts.

Part 1, Politics in Small Cinemas, deals with super-productions in Catalan cinema; Basque conflicts, Basque nationalism and cinema of stereotypes, and local cinema in the Basque region; interpretive anthropology in examining African culture; and finally, Irish cinema and its political content.

In Chapter 1, A call for freedom in the Spanish cinema (from a local perspective), Iwona Kolasińska-Pasterczyk focuses on independence and separatist tendencies of Catalonia and Basque Country in Spain, as well as on national and ethnic stereotypes in Basque and Catalonian identities as expressed in cinema. Two films, Freedom Trilogy (Victoria 1, 2, 3 from 1983 to 1984 by Antoni Ribas), which represents Catalonian regional cinema, and The Price of Freedom (Operación Ogro from 1979 by Gillo Pontecorvo), representing Basque cinema, communicate important independence issues: Freedom Trilogy is a historical fresco dealing with separate national and ethnic identity of Catalonia whereas The Price of Freedom discusses the independence attempts of Basques and the activity of ETA (Euskadi Ta Askatasuna) under the Franco regime.

Karolina Kosińska in The troubled image: The conflict in Northern Ireland as seen by the Irish and the British discusses this conflict not only in a political but also in a national, ethnic, religious, and cultural sense. In her chapter, she addresses the following questions: Is "The Troubles" only an Irish matter? Or, maybe it has a lot to do with the post-colonial issues of the British? Do we deal with the "appropriation" of history here or with a difficult experience shared by both nations?

In Are they terrorist or victims? Basque cinema, violence and memory, Katixa Agirre discusses the film Lasa eta Zabala by Pablo Malo, in which a recent violent past in the Basque Country is revisited on screen. It tells the story of two young ETA militants who become the first victims of the GAL (Grupos Antiterroristas de Liberacion), the state-sponsored death squad that killed 27 people in the 1980s.

While Basque cinema of previous decades often represented ETA sympathetically, now that ETA is defeated this is a difficult topic to engage with: it tells the story of two victims that were originally terrorists. Lasa eta Zabala 
decontextualizes political violence and ends up being too cautious to really venture into the reasons and consequences of these brutal acts.

Gorka Etxebarria and Josu Martinez in A traditional stereotype for modern Spanish politics: The Basque pro-independence coalition Herri Batasuna and its depiction in a cinema analyze the representation made in Basque cinema about Basque "patriotic leftist" politicians. Their hypothesis is that during the last decades, the patriotic left's politician has been regarded as an element that makes a cynical use of its social bases and ETA militants, being much more fanatic than them and without any romantic halo. They analyze five different films made after the approval of 1978 Constitution in order to consider the reasons for this stereotyping.

Iratxe Fresneda and Amaia Nerekan in New content and aesthetics in small cinemas: The case of Basque-language films 80 egunean and Loreak explore how local cinema can become global cinema by analyzing the films 80 egunean and Loreak and examining their content and the aesthetics tied to the production, distribution, and exhibition.

Finally, Paulina Cichon in The image of living of local people in the film Timbuktu: Between the literal and the symbol analyzes Timbuktu, a film made by Abderrahmane Sissako, which breaks the stereotypical portrayal of Islamic fundamentalists and their victims. Using poetic depictions, the film's director translates qualities of other cultures and ways of understanding these cultures into our own language. The unique nature of this intercultural translation consists in the fact that this filmic narration can be compared to Levinas's "look into the face." "Islamist fundamentalism" and its victims demonized in the media become subjects. A different way of illustrating local worlds implies the creation of a new narration when attempting to read meanings and senses hidden in the artistic creation of Abderrahmane Sissako.

Part 2, Gender and Sexuality, discusses gender and sexuality in Slovak cinemas, social drama film in Slovak cinemas, and homosexual portrayals in Polish and Turkish cinemas.

Jana Dudková in Tourists, migrants and travellers: The role of women in reshaping Slovak (cinematic) identity aims to point out the role of migration in reshaping not only the cinematic images of Slovak identity, but also the Slovak cinema as such. Many of these films were made by female scriptwriters/directors, signaling also the appearance of a completely new gender structure of a small national cinema.

Katarína Mišíková in Reality of corporeality: Female corporeality in recent Slovak social film dramas deals with specific ways the experience of female corporeality in crisis is presented by accentuating the relationship between the physical and 
the social bodies. She examines depictions of various physical and social aspects of processes that female characters of recent Slovak social dramas are subject to, such as adolescence, aging, pregnancy and motherhood, physical (self-)abuse and violence.

Sebastian Jagielski in Before coming out: Queer representations in contemporary Polish cinema discusses dominant and marginalized strategies of the reception of LGBTQ (lesbian, gay, bisexual, transgender, and queer) films in the social and historical context of Poland. In 2013, the Polish LGBTQ cinema came out of its hiding place, thanks to two important films, In the Name Of ... made by Małgorzata Szumowska and Burning Skyscrapers made by Tomasz Wasilewski, which have not only situated gay themes in the center of cultural debate in Poland but also moved them to the mainstream, the matters discussed by the author in detail.

Bartłomiej Nowak in To be or not to be yourself: Turkish diaspora and the foreign land - stereotypes, nation and (hetero)norms analyzes a few films of the German-Turkish and Austrian-Turkish cinema directed by Fatih Akın, Kutlug Ataman and Umut Dag. He's interested in the functioning of the Turkish diaspora in the German-language societies of the West, in topics of cultural differences, gender, sexual identity, and transformations of the traditional Turkish family. Discussing such problems as honor killings, patriarchalism and homophobia of Muslim diasporas, Nowak tries to answer the question if diasporic cinema is able to change stereotypical perception of ethnic minorities.

Part 3, Stereotypes and Social Polarities, includes two striking chapters on the presentation of Roma people in film.

Jadwiga Hučková in Exposed and concealed Roma conflict: Representation of contemporary Roma conflicts in Czech Republic, Slovakia, Poland and Hungary discusses Roma conflict as one of the dominant issues that societies and cinemas of Eastern Europe should face. Recently, a variety of deeply touching fiction films have been created like Just the Wind by Benedek Fliegauf and Judgment in Hungary by Eszter Hajdu. Hučková discusses three films in detail: Moving a Settlement or The Roma King by Viliam Poltikovič, Koza by Ivan Ostrochovský, and The Queen of Silence by Agnieszka Zwiefka, and presents various variants of the representation of Roma conflict in these films.

The topic of Chapter 12 by Iwona Grodź presents stereotypes, antagonisms and signs of intolerance related to ethnic minorities in Poland. The references used for this chapter include the film by Krzysztof Krauze, Papusza (where he presents Roma minority). First, the author pays detailed attention to the director's body of work in view of his interest in social problems, conflicts, and controversies in the presentation of minorities. In the later part of the chapter, the author deals with the ways stereotypical presentations are changed in the aforementioned film. 
Part 4, Theory and Small Cinemas, deals with avant-garde in Japan, mockumentary cinema of Michael Moore, and migrants and exiles in Polish cinema.

A methodological starting point of Chapter 13, Migrants and exiles in the films by Katarzyna Klimkiewicz, by Krzysztof Loska is transnationalism as understood by Will Higbee and Song Hwee Lim who claim that the concept does not only refer to co-production or global distribution but also include political, cultural, and social factors that help promote understanding contemporary cinema and the world around us. This is the perspective the author of the chapter assumes when analyzing the films by Katarzyna Klimkiewicz who mainly focuses on ethnic minorities and their problems. Based on the analysis of Klimkiewicz's two films, the author proves that contemporary cinema tackles "a migrant issue" in different ways.

Agnieszka Kiejziewicz in her chapter From controversy to contemplation focuses on the question: why the new generation of the Japanese filmmakers tries to be politically correct while stating that they follow (and even improve) the postulates of the old masters? Analyzing the chosen films, she shows that the lack of controversy can also be controversial, if it is compared to the achievements of the previous generations.

Janina Falkowska in Mockumentary cinema and its political might analyzes Michael Moore and Sacha Baron Cohen who make their films in the manner of mockumentary, each of them using their investigating personas to remake the news across "their own image and agency." Eventually, they create politically powerful and boisterous carnivalesque films far exceeding the effect of a mere presentation of fact. The author is especially interested in the ways these films cross genre boundaries and emerge as a separate small cinema with its own semantics and syntax on the border between documentary and fiction film.

Part 5, Aesthetics of New Small Films, deals with the portrayal of the personal and the nation in American aboriginal cinema, social exclusion in Polish cinema, political myths and restorative nostalgia in Hungarian cinema, and post-industrial landscape in the newest Silesian film.

Phil Mann in De-Centered subversion: Hukkle and the challenging of revisionist historiography seeks to examine the ways in which György Pálfi's Hukkle challenges the politics of memory in contemporary Hungary. Through the film's penetrative cinematography and heightened, manipulated audio, the author argues that Hukkle invites its audience to examine its seemingly bucolic representation of rural Hungary more closely. He views the aesthetic treatment of Hukkle as a metaphor for the manner in which history has been remembered in postcommunist Hungary. 
Chris LaLonde in "I don't know": Linking past and present, the personal and the nation, and movement in Sterlin Harjos This May be the Last Time proposes to discuss how, in the documentary This May be the Last Time (2014), Muscogee Creek-Seminole filmmaker Sterlin Harjo brings together personal history, local history, the history of removal, World War II, the Vietnam War, and congregational line singing in order to articulate connections between past and present and between song and loss in the name of what Gerald Vizenor terms survivance. The stories of movement help link the personal with something larger - a critique of the nation, a recognition of connections, and a celebration of adaptability and community.

Ilona Copik in Post-industrial landscape in the "Silesian cinema": Between the aesthetic and cultural experience discusses contemporary fiction films which represent a particular aspect of Polish cinematography, e.g. "Silesian cinema." The main purpose of the author's analysis is the nature and look of landscape in a small cinema. The author ponders the question how a small cinema reflects on the "local aspect" of landscape and in what sense cultural stereotypes and visual conventions still dominate this landscape.

Marta Stańczyk in Once upon a time there used to live a people ... Neighborhooders and The Heritage as fairy tales about the Polish "excluded" mainly deals with the ways of expression and the poetic language used, including the grotesque, mythologization of discourse, universalization of space, and the use of anachronic narrative formulas (sylves, fairy tales, and ballads) in the presentation of lower classes in Poland. The author looks at two films, Neighbors by Grzegorz Krolikiewicz and Ghosts by Andrzej Baranski, and focuses on a new language of expression to portray the fate of a lower class.

All the aforementioned authors deal with their objects of study in the theoretical framework valid for a vast array of debates in today's world: national identity, ethnic identity, stereotypes, appropriation of history, political violence, international mobility, homophobia, transnationalism, multiculturalism, racism, and discrimination. Supported by thorough research, these unique chapters shed light on contemporary areas of controversy. Their writers show real courage, expertise, knowledge of subject matter, insightfulness, and intelligence when tackling their subject matter.

The book we present for publication has been inspired by the conference on small cinemas in Krakow. The conference in Krakow is the seventh conference in a series of conferences on the same topic. Six conferences have already been organized relating to the subject of small cinemas in Canada, Europe, South America, and the United States. Previous international conferences took place as 
follows: (1) 2010 - European Visions: Small Cinemas in Transition, Department of Film Studies, University of Western Ontario, London, Ontario, 29 June-2 July; (2) 2011 - Small Cinemas: Small, Smaller, Smallest, The State University of New York at Oswego, New York, 16-18 September; (3) 2012 - Small Cinemas: Promotion \& Reception, Timisoara, Romania, 1-3 June; (4) 2013 - Small Cinemas. Crossing Borders, Florianopolis, Brazil, 4-6 September; (5) 2014 - Crisis in Film and Visual Media, Vilnius University, Vilnius, Lithuania, 19-20 September; (6) 2015 Filming Locations. The Fabric of Culture, Myth \& Identity, Valletta, Malta, 24-26 September. The six previous conferences concentrated on their themes, aesthetics, and conditions of production. An important outcome of all these conferences was the publication of two books, European Visions: Small Cinemas in Transition, eds. Janelle Blankenship and Tobias Nagl (Bielefeld, Germany: Transcript Verlag, 2015) and Small Cinemas in Global Markets: Genres, Identities, Narratives, eds. Lenuta Giukin, Janina Falkowska, and David Desser (Lanham, Maryland: Lexington Books, 2015). We hope to continue this trend with the publication of the present book after the conference in Krakow. 



\section{Part 1: Politics in Small Cinemas}





\title{
Iwona Kolasińska-Pasterczyk \\ Instytut Sztuk Audiowizualnych, Uniwersytet Jagielloński, Poland \\ 1. A call for freedom in the Spanish cinema (from a local perspective)
}

\begin{abstract}
My presentation focuses on independence and separatist tendencies of Catalonia in Spain, as well as on national and ethnic stereotypes in Catalonian identities as expressed in cinema. Freedom Trilogy (Victoria 1, 2, and 3 from 1983 to 1984 by Antoni Ribas), which represents Catalonian regional cinema, serves as a basis for understanding of the identification with a community and the perception of the local distinction. The film communicates an important independence issue: Freedom Trilogy is a historical fresco dealing with separate national and ethnic identity of Catalonia.
\end{abstract}

Keywords: Microregionalism, cinema Catalan, national identity, cine autonómico, Catalan identity, Catalan culture, historical super productions, Victoria 1, 2, 3

A historical reconstruction enables the recovery of a lost memory. ${ }^{1}$ In the case of Catalonia, a turn towards the past in the Spanish cinema that started in the so-called "transition period" (1975-1982) had a special significance because of the importance of nationalist tendencies that were present in the region. The Catalan cinema, as a cinematography separate from the national one, first appeared after the first free elections in Spain held on 15 June 1977 and granted some national groups and regions a certain level of autonomy (including Catalonia and the Basque Country). The Catalan Cinema Institute was created by a group of Catalan cinematographers and intellectuals on 20 December 1975, only 1 month after General Francisco Franco's death (20 November 1975). The first commercial success of the Catalan cinema was La ciutat cremada (Burnt City, 1976) directed by Antoni Ribas, set between the years 1899 and 1909. Antoni Ribas revived the Catalonian history with two pieces - the above-mentioned Burnt City and the so-called "freedom trilogy," a historical fresco in three acts, Victoria parts 1, 2, and 3, produced between 1983 and 1984. In 1985, Catalan filmmakers established the Association of the Directors of the Catalan Cinema with Bigas Luna chosen as its president and Antoni Ribas as vice-president.

1 Jean-Claude Seguin, Histoire du cinéma espagnol (Paris: Éditions Nathan, 1994), p. 90. 
"A Call for Freedom" in the Spanish cinema, with its national specifics, is best depicted in the "freedom trilogy" - Victoria parts 1,2, and 3. This film belongs to the cine autonomico (regional cinema) trend presenting the essence of Catalonian "dream of autonomy."

\section{“The Freedom Trilogy"}

Ribas' "freedom trilogy," a historical super-production of the Catalan cinema, consists of three films: Victoria! La gran aventura de un pueblo (Victory! The Great Adventure of the Catalan People) [Victoria! La gran aventura d'un poble], released on 9 September 1983; Victoria!-2 (El frenesi del 17/The Frenzy of the 1917) [Victòria 2: La disbauxa del 17], released on 6 December 1983; and Victoria!-3 (La razón y el arrebato/Victory!-3: Reason and Exultation) [Victoria-3: El seny i la rauxa], released on 3 February 1984. It was produced in two language versions Spanish and Catalan.

Ribas' monumental historical epic poem in three acts (the first part is $142 \mathrm{~min}$ utes long, the second and the third 135 minutes each) reminds the viewer of the beginning of the Restoration Period (1917-1930) in Spain ${ }^{2}$. Precisely, it covers the period between 1917 and the rise of Primo de Rivera's dictatorship (Rivera was the commander of the military district in Catalonia between 1922 and 1923 and the Spanish Prime Minister after a peaceful coup détat that took place on 13 September 1923). The action of all the parts of the film takes place in Barcelona. The main plot is set against the background of World War I (in which Spain was not involved) and develops as an aftermath of the events happening in Russia. Echoes of the victory of the October Revolution reach the anarchists proclaiming revolutionary slogans about liberation. The plot depicts the crisis in the country - a political, ideological, and governmental crisis that culminated between 1917 and 1918- and it illustrates the road of the Catalonians to achieving full autonomy. The fight against centralisation of power in Madrid is symbolised by the preparations to blow up the Montjuic fortress standing on a hill over Barcelona, representing the oppression of the regime. The plan of destroying the fortress links all three parts of the trilogy.

The action of the first part of the trilogy starts in June 1917, the year when a "period of deep upheaval which transformed Spanish society" 3 began. The

2 See Manuel Tuñón de Lara, Julio Valdeón Baruque, Antonio Domínguez Ortiz, Historia Hiszpanii [History of Spain], trans. Szymon Jędrusiak, (Kraków: TAiWPN UNIVERSITAS, 1997), p. 522-544.

3 Manuel Tunón de Lara, Julio Valdeón Baruque, Antonio Domínguez Ortiz, Historia Hiszpanii, p. 522. 
ideological crisis among the ruling class led gradually to the crisis in the country, and it all took place when Spain's economy was affected by World War I - "although Spain did not directly take part in the War, the years 1914-1918 shaped its history throughout the 20th century."

There is a certain analogy between Ribas' epic Catalan tale and Bernardo Bertolucci's Novocento (1976, Twentieth Century, aka 1900). Both directors focused on showing the events of 1 year which caused consequences for the whole of the twentieth century. In Bertolucci's film, the year 1900 was the moment that determined the future for the characters of the film and for Italy. In Ribas' take, the future of the Catalonian people, who are a collective character in his trilogy, was decided in 1917. Bertolucci's monumental spectacle (consisting of two parts - the first that lasts 162 minutes, and the second that lasts 154 minutes) cost \$9,000,000. Victoria, being the biggest and the most lavish historical production of the Catalan cinema, stands the comparison with the Italian piece in the aspect of the immense scale. The budget, originally estimated at 300 million pesetas, finally exceeded 450 million. ${ }^{5}$ Both films tackle the idea of revolution and in both the revolution is postponed until the future - Bertolucci would present "stages of revolutionary utopia"; for Ribas, the revolution was a dream of an anarcho-syndicalist, who was an idealist and pacifist at the same time. Bertolucci's political notion can be put into words: "History is created by every man's desire, but only in the extent to which it is pursued." These words can be also attributed to Jaume Canals (starring Xabier Elorriaga), the main character in Ribas' trilogy, who evolves from a barely noticeable trade unionist smuggling weapons (in the first sequence of the first part) to the leader of all unionists, concluding an alliance with one of the junteros - lieutenant Rodriguez Haro (portrayed by Helmut Berger), despite all divisions between them, to change the course of history (in the third part). Both in the film by Bertolucci and by Ribas, the protagonist impersonates a form of a romantic fight that is doomed to fail. Bertolucci's 1900 was a take on the relation between the past and the present, with the

4 de Lara, Baruque, Ortiz, Historia Hiszpanii, p. 522.

5 “Antoni Ribas estrenó 'Victòria!', la mayor superproducción de la historia del cine catalán,” El Pais (10.09.1983): 15 Sep. 2016, http://elpais.com/diario/1983/09/10/ cultura/431992808_850215.html.

6 Joël Magny, "Polityczny wymiar twórczości Bernarda Bertolucciego od Przed rewolucją do Wieku XX" [The political aspect of Bernardo Bertolucci works from Before the Revolution to Twentieth Century], in: Bernardo Bertolucci w opinii krytyki zagranicznej [Bernardo Bertolucci in the opinion of foreign critique], ed. Tadeusz Miczka (Warszawa: Filmoteka Narodowa, 1993), p. 130.

7 Magny, “Polityczny wymiar twórczości Bernarda Bertolucciego," p. 130. 
plot developing from 1900 to 1945. It was addressed to the viewer from the 1970s. Ribas' trilogy refers to the times that, after a series of conflicts, eventually lead to Catalonia being granted full autonomy. It is known from history that Mancomunitat of Catalonia held an assembly of representatives in Barcelona on 21 December 1918 during which a decision was made to act immediately to acquire full autonomy, and on 26 January 1919, a draft of The Statute of the Autonomy was acclaimed. ${ }^{8}$ But the trilogy was filmed with the perspective of a creator from the post-Franco era: a creator who was aware of the results of Primo de Rivera's dictatorship (the abolishment of all privileges of the Catalonians in 1925) and of the later consequences of General Francisco Franco's victory, which started a long-lasting period of dictatorship (all privileges were cancelled in 1939). ${ }^{9}$

\section{Freedom! A Great Adventure of the Catalan People}

The opening shot in Victoria! A Great Adventure of the Catalan People shows the walls of the Montjuic fortress, which is an army base, located on top of a cliff overlooking the sea between the port and the city. The fortress (now Castell de Montjuic) is a notorious prison where political prisoners were being detained and murdered. Currently, the Catalans consider this place as a symbol of the struggle for independence and liberation. The last shot in the film is a close-up on the intertwined hands of three junteros dressed in civil clothes, including Lieutenant Rodriguez, which symbolise the alliance in the struggle for a new Spain.

The first part of the trilogy sets the socio-political situation in Barcelona against the background of the situation in the whole country determined by Spain's decision to remain neutral in the face of the war in Europe (the decision was declared in Madrid in 1914 by the Prime Minister Eduardo Dato). ${ }^{10}$ It is accentuated that there are diverse social strata and disproportions in the quality of life between those who benefit from the neutrality - entrepreneurs and bourgeoisie earning fortunes from trade and wealthy aristocrats, and the impoverished social groups who earn a stable income, a salary, like the workers in the trade unions, or a soldier's pay, in the case of the army. The disproportions can be noticed already in

8 de Lara, Baruque, Ortiz, Historia Hiszpanii, p. 529.

9 The parliament and Generalitat were liquidated, Catalan language was banned in public places, statute was suspended, national symbols were prohibited, which initiated conspiracy - the Catalan National Front was established (Front Nacional de Catalunya). Retrieved: "Historia Katalonii" [History of Catalonia], Historia Katalonii/Cules/FC Barcelona, 15 Sep. 2016, http://www.blaugrana.pl/cules/historia-kataloni, p. 5.

10 de Lara, Baruque, Ortiz, Historia Hiszpanii, p. 524. 
the first sequence of the film, which takes place by the waterfront in Barcelona. Elegantly dressed members of the high society are leaving the Great Theatre of Catalonia during the "Cinematograph" spectacle, for a more wanton entertainment on the beach. The local inspector Sánchez also enjoys a dissolute company of women of easy virtue who start "a Babylonian bath, Babylonian and shameless." Local poor men arrive at the waterfront to plunder remnants of a scattered shipwreck where they find loot - shoes that leave imprints creating a "lane" in the sand, and that turns out to be made of paper. At the same time, sheltered by the night, a trade unionist Jaume Canals tries to sneak through the Coast Guard controls as he gets weapons smuggled in a box. By dawn, a strange shape emerging from the sea attracts the attention of a woman standing by the waterfront theatre and as she looks through her binoculars she sees other people, with binoculars as well - a short man in a bowling hat carrying a poster advertising a double session of "Cinematograph" at the Great Theatre of Catalonia (Gran Teatre Ctalunya, Sessio doble de CINEMATOGRAF), men in white suits standing on a balcony of the Casino building, one of them making flash signs, a man in a black tuxedo and a top hat on a bridge, a man who has just finished caressing a woman, and then all of them (still in their gala outfits) gather on the shore and look through their binoculars towards the sea. Someone says: "it must be a sea snake," another: "No, it's a whale," and yet another: "It's rather a submarine." Eventually, they recognise: "It is a German submarine. How did it get here?" and they start betting "is it going to shoot or not?" The Chief of the local police, Superintendent Bravo Portillo refuses to believe that the Germans might have entered the neutral waters damaging international relations. When "the observers on Her Majesty's Services" confirm that they have seen the vessel, he threatens them that they will be detained under the charge of being drugged with cocaine. This "violation of Spain's neutrality" by the Germans, as one of the men notices, becomes an impulse for exchanging opinions and expressing slogans that illustrate who supports which political party. Someone shouts: "Long live the freedom of trade!", another: "Long live the allies!", yet another: "Long live the European empires!", someone cries, "Long live the democrats!". And the woman and man who were intimate at night start singing (she in German and he in Spanish) symbolically standing on two sides of a barricade. A worker appears among those "united by emigration" (later it turns out he is a police spy) and accuses the society: "This society is responsible for you being a whore, you being a parasite and you thieves, crooks or smugglers" and then proposes: "War is on the side of those who rule. Let's overthrow the government and put an end to this war!" The ship in the harbour with the word "NEUTRAL" on its side, the submarine emerging from the sea with the German sailors, and a 
small boat carrying a box with weapons transported by Canals and his helpers all symbolise the line dividing society into germanófilos and aliadófilos, according to their political preferences. The initial sequence of the film is audacious in the way it shows the absurdity of the situation, combining the seriousness of political issues with a dose of sense of humour, which is characteristic of the first part of the trilogy.

The next sequences of the film show Barcelona as the centre of political and social events leading to the decentralisation of power (becoming independent of Madrid). Jaume Canals, a trade unionist and activist, collects weapons for his comrades, because the weapons are "the key to the power that the army has over the city." They want to conquer "the line of fortifications, from which the viceking rules Catalonia" and destroy the fortress that the Catalonians have wanted to destroy for a century. He makes a plan to organise a general strike that will prepare the grounds for changes in Spain. Lieutenant Rodríguez Haro, who is a member of the junteros movement, is disappointed with some of the soldiers, because "you cannot identify the whole army and the country with one man" and suggests that there is a need to reform the army to restore the people's trust in it and so that the people stop blaming the army for everything that is wrong in the country. He expresses his concerns during an aristocratic party where many intellectuals are present, including a Catalan nationalist Carlos Roula who blames Madrid politicians for everything, hates the soldiers, and viciously attacks Rodríguez saying: "It is time you start living only off soldier's pay and not be supported by rich fiancés like Cristina Luz." Later, Lieutenant Rodríguez makes an offer to the anarcho-syndicalist Canals to join the forces of the Defence Junta and the trade unionists in a fight for a good cause. This happens after the leader of the Juntas de Defensa (Defence Junta), Colonel Benito Márquez is arrested. Colonel Benito Márquez (played by Francisco Rabal), the chief of the Vergara regiment at the Barcelona garrison and the leader of the junteros in the army, allowed for training that was against the rules and disrespected an order from the military supervisor. When he is summoned to the headquarters, he is ordered by his supervising general to dissolve the juntas, but he refuses to execute it, surrendering to the general as a prisoner. He is arrested for insubordination and transported to the Montjuíc fortress. The colonel tells Rodriguez to respect the law and not to rebel against the given orders - he is more respected among the soldiers than the generals who are not capable of enforcing orders on the army without his support. The soldiers who sympathise with the colonel await his orders. Rodriguez turns to him saying: "Spain needs you," but he goes to the fortress telling them: "I command you to be obedient and to wear your uniforms 
with pride." It is Rodriguez who starts defining the political aims of the junteros after Márquez's arrest. Those aims are the dismissal of all generals, creation of the Nation's Liberation Government, and conciliation with the people. He sees the role of Canals and the alliance with the trade unionists as a means to achieving this last aim: to reconcile soldiers and civilians. This unofficial initiative, supported by the majority of junteros, will be the main theme of the third part of the trilogy. The first part closes with a coalition to overthrow the king and to change the political situation in the country, sealed with a handshake of three junteros.

Antoni Ribas uses a sexual metaphor to minimise the pathos of liberation political ideas pronounced by various social groups. Everyone in the politically diversified society, independently of the social group, represents the same erotic vigour. Eroticism is what unites despite divisions and what defines the temperament of a Catalonian. Sometimes it is bawdy, sometimes deviant, and sometimes touches an obscene note. During the time of pursuit for freedom, eroticism is the only sphere of actual freedom - the liberation from costumes and conventions, which is also a road to social promotion. The shots exhibiting the erotic temperament of the characters are often motivated by the convention of a spectacle and they are used as one of the ways of pointing out Catalan uniqueness. In this sense, an aria in an opera inspires a couple to make love. Police Inspector Sánchez takes part in a public "shameless, Babylonian bath" in the sea accompanied by prostitutes. Canals' spouses, spending most of the time separated (because love has to give way to the "idea"), give free reign to their passion whenever they meet, regardless of the circumstances (although they are being watched). Some of the scenes take place in the Parallel, where the nightlife flourishes and the prostitutes are using their charms to lure the men. Canals, responsible for collecting the weapons for the unionists, although a pacifist by nature, soothes a conflict between a father and his daughter Juanita (debutant Eva Cobo) who has engaged in an affair with her dance teacher, which for her meant a first step in getting away from poverty. And all this is put into the frame of an opera spectacle. Striving for freedom corresponds with an atmosphere of sexual liberation. It is a part of cultural identity. Another facet of this cultural identity can be inferred from the poster held in the opening sequence by the man in the bowling hat, the "Catalonian Méliès" (Gran Teatre Catalunya, Sessio doble de Cinematograf) - it is a hint pointing to the fact that by this time Catalonia already had a film studio (brothers Ricardo and Ramón de Baños established The Royal Films Movie Association in 1916). 


\section{Victory!-2 (The Frenzy of 1917)}

In the film Victory!-2 (The Frenzy of 1917), the frivolous atmosphere is even more accentuated and corresponds with the climate of the political frenzy dominating all conflicted sides. As they stroll through the city and discuss how to reinstall order, Superintendent Bravo Portillo and Inspector Apolinar Sánchez get excited about the news like "round, firm, smooth and curvy breasts," "cassials pills," or an advertisement "do you remember about my insatiable lust," and Superintendent Bravo ponders: "We will not know whether there are any revolutionary slogans amongst these advertisements until we get the code. Fortunately, we have some good spies in the police. Our informer says that he knows the key to the code. However, we need to be careful, so that the unionists don't realise it, because if they did, they would change it." Barcelona becomes an arena for spies on the services of the corrupted police, which support the government, but, as Bravo says: "the governments change, but the police stay."

The city is also full of people willing to provide entertainment for the newly arrived German sailors and where the bribed police turn a blind eye on violating international agreements. Pursuant to the slogan: "Good pornography is also an art," "honourable mothers," encouraged by the owner of a club, talk their daughters into dancing for the drunk German sailors. When they resist, one of the women suggests to her daughter: "show, only the thigh," which is overheard and then repeated by the public: "thigh, thigh..." At this point the mother warns "if you don't go out, I'll do the gig myself." Therefore, plump mature mothers do their frivolous dance as the first ones, and then their innocent daughters, looking like white flowers in white dresses, take their place with full "dignity" as they are encouraged: "show the buttocks, girls, the buttocks" - they gradually uncover everything they can and eventually they start dancing like naked nymphs. One of the German soldiers who used the sexual services in the facility refuses to pay, so the police hold the German government accountable for it, issuing a bill with the title: "expenses for the country and the victory." The students catch their teacher with a prostitute. Surrounding him, they make a toast to their passed exam (which they are only about to take) [this toast is a hidden hint to a film by José Luis Garci Asignatura Pendiente (Unfinished Business, 1977), which compromised the old - in this case Franco's era - moral norms. The film was one of the many in the postFranco period that contested the existing moral order]. ${ }^{11}$

11 Emmanuel Larraz, Le cinéma espagnol des origines à nos jours (Paris: Les Éditions du CERF, 1986), p. 248. 
Sheltered by night, the unionists keep collecting the weapons, continuing the preparations for a general strike. The police superintendent knows about the contraband, but prohibits everyone from doing anything about "the vanishing weapons," because he wants to shift the problem to the military intelligence. In another place, in the evening, an announcer introduces an exciting theatre spectacle: "Ladies and Gentlemen...You are witnessing the greatest controversy that has shaken the foundations of Christianity. Here, in front of you, there it is, the loathed, disputed, defamed, shameless, obscene, plebeian, vulgar, salacious, animalistic, passionate, bawdy and always fantastic...tango." At this moment a couple of dancers - Juanita and her teacher - start performing tango moves to the choir singing of seminary students (which sounds nothing like any dance music) in front of the public composed of prelates. The dance is interrupted: "This cannot be, my children - one of the prelates says - Tango is danced with passion. It is a hot and passionate dance. Or at least that is what they said..." and encourages the dancers: "Forget about the House of God and think that you are in the most deprived cabaret in the fifth quarter. This is at least what I have heard. Tango does not exist in Latin. We are bound by the anthem to be persistent and to pursue so that the master Millet himself approves of this sinful dance. Let's not forget that [a quote in Latin:] 'no one shall say that the Church does not make an effort.' We also still need an accordion in order to make the diocesan committee understand, what tango is." The longer the couple dance the Argentinian tango on the floor, the merrier are the smiles on the faces of this atypical audience. The most frenetic and passionate of all dances, tango in this scene looks like taken straight from a Fellini film that perfectly illustrates the absurdity of the surrounding reality.

The police use the services of a spy to prepare a provocation that should enable them to destroy the unionists and Inspector Sánchez kidnaps Canals' children to get him into a trap. Maria, the mother of Canals' children (played by Norma Duval), blames him for the disappearance of their children and declares she would claim to take them back, as they should be with their mother and not their father's mistress Palmira (played by Carme Elias). The two friends now stand against each other, and Maria warns her rival: "Jauma needs to screw some lass from time to time, and as you well know, this is not how he treats the women of his life." Maria wants to file a lawsuit to strip him of parental rights motivated by the facts that he neglects his family and she is going to marry (for the sake of the children) Mr. Llorenç Vinyes, so that he can take authority over them. When Canals eventually finds Inspector Sánchez to recover his children, the Inspector's mother tells him that they are sleeping like angels, whereas Canals' daughter is being sexually assaulted by the Inspector's brother in an adjacent room. When Canals decides to 
open the door to this room using force, Sánchez points a gun at him. "It is a real hunting gun, isn't it?" Canals asks, making a reference to the memorable film by Carlos Saura The Hunt (La Caza, 1965). ${ }^{12}$

Earlier, Juanita met Lieutenant Rodriguez Haro at a crossroad (the Y-shape symbolising the choice of the road in life) and foretold him that he would need her help. Haro meets with lieutenant colonel and his supporters, and this meeting shows a division among the soldiers. One fraction supports the coup détat and liberating colonel Márquez and the members of the High Junta (as long as he is in prison he cannot be defeated) and the other backs coalition with the people (this is the part of the junteros led by Rodriguez). The first group is afraid that the separatists shall exploit the division in the army in their fight for autonomy. Rodriguez declares: "We do not want another coup, but far-reaching reforms. Can't you see that you are falling into another trap set up by the generals from Madrid?"

Political ideas and main characters of the political plot remain overshadowed by the absurd reality of the second part of trilogy. Colonel Márquez is barely mentioned, Lieutenant Rodriguez gradually matures to take over initiative and a family drama crosses Canals' unionist strike plans. He is abandoned by the mother of his children who is planning to marry his friend (a unionist turned entrepreneur). There are two closing shots. The first one shows a breakup in the family (the son stays with his mother and her husband-to-be and the daughter stays with her father). In the other there is a watchman with gun.

In the second part of Ribas' trilogy, the madness of 1917 is illustrated in situations that reach the limits of absurdity. Those were the circumstances that the Catalans had to endure, deriving from both the crisis in the state and the echoes of shocks that shook Europe (war and revolution). The specific take on this historical issue reveals the temperament of a true Catalan, who keeps his sense of humour even confronted with the absurdity of history.

\section{Victory!-3 (Reason and Exultation)}

As a matter of fact, Victory! by Antoni Ribas is not only a trilogy, but in composition terms it is based on the triptych scheme. All the parts - except for one retrospection in the third one (when Canals recalls April 1904 when for the

12 The Hunt by Saura was showing the times of the Spanish civil war as a source of a national trauma; the rabbit hunting taking place in an empty arrayo has the function of "masking the murderous instincts." Alicja Helman, Ten smutek hiszpański. Konteksty twórczości filmowej Carlosa Saury [This Spanish sadness. Contexts of the film works by Carlos Saura] (Kraków: Rabid, 2005), p. 56. 
first time he shouted: "Long live the anarchy! Away with the king!" during the visit of the king Alfonso XIII) - present the events in the chronological order. However, the relation between each of the parts indicates it is a triptych. There is a specific correspondence in the arrangement between the threesome's stories. Ribas' Victoria! is a set of separate parts, but these parts are also complementary elements of a bigger unit. In the case of a triptych, although the paintings are separated, they are not isolated - they relate between each other. The whole of the triptych should be read simultaneously, not in chronological order. In the case of this triptych trilogy the second, the most shocking part, takes the place of the central piece, translating absurd of history into the language of eroticism. Sociopolitical situation in Barcelona and the present liberation tendencies dominate the first part. They are illustrated, not solely, but with the use of a sexual metaphor. The third part combines the issues of a big-scale (like making the history) with those that are private, personal (like love and death).

First words uttered in Victory!-3 (Reason and Exultation) is the famous quote: "The die is cast." Those are said by an officer (Pablo) approaching Lieutenant Rodriguez Haro as he fastens the buttons of Jaume Canals' uniform. The quote, attributed to Julius Caesar who allegedly said it as he crossed the Rubicon (10 Jan $49 \mathrm{BC}$ ), signified the end to an old republican system and the birth of the Roman Empire. Here it refers to the alliance between a part of the liberal junteros and the unionists, a point of no return. Rodriguez, once standing at the crossroads (as is the scene with Juanita and the second lieutenant), now takes an irrevocable decision - he is going to intervene in the course of history. Jaume Canals says: "The unionists think that Barcelona is a bomb and all that it lacks is a fuse and I think that this city is a fuse and the whole country is a bomb." His companions unionists who object to the war idea - dress up in military uniforms to hide their identities and help Lieutenant Rodriguez Haro and his supporters in an action of not allowing the order of releasing Márquez from reaching the castle. For the unionists, this theatrical gesture (one of them says he looks like a drummer in an operetta) is a test, checking if they can count on a coalition with the army. Simultaneously, another group of unionists mines the Montjuíc hill to set the fortress on fire. The first ones are climbing up the hill to prevent releasing Márquez, the others are placing dynamite to destroy it, as: "Maybe the people will lose fear and they will feel free seeing how the symbol of oppression crumbles down." The first group of the unionists fail their mission. As a result, Rodriguez Haro will face expulsion from the army and Jaume Canals will have to seek shelter in the house of his ex-wife's new husband. 
The political plot is developing from the first part of the trilogy. Now it is completed with the personal perspective - the troubles that started in the second part. The private perspective has a function of a memento mori of its kind. It is developed in grotesque, exaggerated sequences. Three men - a priest, a solicitor, and a doctor - pay their visits to the groom Lloren Vinyes Bajzels before his wedding with Maria Allaga. The first one wants to convince the democrat that he should make his vows before God, and to remind him of his mortality. The second one tells the groom to use the opportunity and write down his last will. The third one visits him because he could never forgive himself if he was not present by his deathbed. The wedding is a pretext to remind of death. The priest says: "Those, who believe, shall not perish but have eternal life, but you are going to die, Lloren Vinyes Bajzels..." and the former unionist who became an entrepreneur and a democrat, thinking about the future, pities that "It may turn out that peace in Europe will lead to our fall or to a civil war." This far-reaching intuition of Vinyes represents the perspective on history adopted in the film.

Maria and Llorenc's wedding party coincides with the great explosion. One of Canals' companions tells him: "We have lit the fuse of revolution" as he points to the Montjuíc castle and the hill shaking from a series of explosions. Although one plan failed (Márquez, afraid of the possible division of the country, did not join separatists and dissidents), the other one worked, strengthening the myth of Agrato Vidal, a fantom anarchist - in the reality Jaume Canals. Two months after the wedding the solicitor, the doctor, and the priest come again to Llorenc Vinyes' house. The first one comes to write down the last will of the dying man, according to his wish. The doctor is told that Vinyes is too ill to talk to him. The third one follows Vinyes who has got up from the deathbed and went out to the streets so that the death would have to chase him. Before his departure, he calls for Canals and explains that he married Maria so that his fortune would not be taken over by the government, but it would be inherited by Maria and her children. This dimension of the plot is completed with two deeds of love: Juanita manages to use some "influential acquaintances" to close the case against Rodriguez and she returns him to Cristina Luz, and Vinyes leaves all his fortune to Maria, which brings the whole family together. In the end of this sequence of grotesque situations, the Police Superintendent Bravo Portillo is shot in the street (on 15 September 1919), Colonel Márquez is dismissed from the army (February 1918), and Maria and Canals visit the astronomical observatory one day before Primo de Rivera overthrows the government (on 12 September 1923). In the guide to the observatory there is information that one of the planets is called Barcelona, so "we have a second Barcelona in the space." And Canals-Agrato Vidal asserts: 
"Our problems are small and insignificant when seen from the perspective of the Universe." His last words in the film seem like a message: "I am sure of one thing though. We cannot allow others to impose their customs, language and laws on us. There is no one who can tell us we shouldn't be ourselves." This is a claim to maintain cultural identity. Although it is said the day before installing military dictatorship by Primo de Rivera, this "dream of autonomy" will be only fulfilled in the post-Franco period.

"The dice is cast" quote, inaugurating the third part, makes the viewer realise that what is present (the autonomy granted after General Franco's death in 1975 and the introduction of a new constitution in Spain in 1978 - the state that was when the film was being produced) many years ago was only the future. The third part presents alternative historical paths for Catalonia and the "victory" - the destruction of the Montjuíc fortress - is a visions of a desired "past" and partly a utopian future (the fortress was never destroyed, but nevertheless it remains as a symbol of the once oppressive rule). In the third part, Antoni Ribas showed the stages of a revolutionary utopia (also through the means of a grotesque exaggeration of the action) with "Barcelona in space" at the dawn of Primo de Rivera's dictatorship.

\section{Conclusion}

Victoria!-1, 2, 3 is the biggest historical production in the local Catalan cinematography. It conveys the vivid culture and temperament of the Catalan people. The seriousness of the theme is mixed with a grotesque perspective. The pathos is minimised by remaining ironically distanced from the situation. It tells about the history from the present-day perspective. It shows that Catalan identity is based most of all on the language and culture and the historical motifs. It refers to "personal mythology" to present the regional history. As a super-production representing cinematography of a micro-region, it stands as a symbol of the domination of Madrid. It is also an evidence of a "new freedom of expression"13 that came with the fall of Franco's dictatorship.

13 Marsha Kinder, Blood Cinema. The Reconstruction of National Identity in Spain [8. Micro- and Macroregionalism in Catalan Cinema, European Coproductions, and Global Television], University of California Press, Berkeley and Los Angeles 1993, p. 395. 


\section{Bibliography}

Antoni Ribas estrenó 'Victòria!', la mayor superproducción de la historia del cine catalán, El Pais 10.09.1983: (15.09.2016) retrieved: http://elpais.com/ diario/1983/09/10/cultura/431992808_850215.html

de Lara, Manuel T., Baruque, Julio V., Ortiz Antonio D. Historia Hiszpanii [History of Spain]. Trans. Szymon Jędrusiak. Kraków: TAiWPN UNIVERSITAS, 1997.

Helman, Alicja. Ten smutek hiszpański. Konteksty twórczości filmowej Carlosa Saury. [This Spanish sadness. Contexts of the film works by Carlos Saura]. Kraków: Rabid, 2005.

Historia Katalonii [History of Catalonia], Historia Katalonii/Cules/FC Barcelona Online, (15.09.2016) retrieved: http://www.blaugrana.pl/cules/historiakataloni.

Kinder, Marsha. Blood Cinema. The Reconstruction of National Identity in Spain. Berkeley and Los Angeles: University of California Press, 1993.

Larraz, Emmanuel. Le cinéma espagnol des origines à nos jours. Paris: Les Éditions du CERF, 1986.

Magny, Joël. "Polityczny wymiar twórczości Bernarda Bertolucciego od Przed rewolucja do Wieku XX." [The political aspect of Bernardo Bertolucci works from Before the Revolution to Twentieth Century], trans. Tadeusz Szczepański In: Bernardo Bertolucci w opinii krytyki zagranicznej [Bernardo Bertolucci in opinion of foreign critique], ed. Tadeusz Miczka. Warszawa: Filmoteka Narodowa, 1993, pp. 111-133.

Seguin, Jean-Claude. Histoire du cinéma espagnol. Paris: Éditions Nathan, 1994. 


\author{
Karolina Kosińska \\ Instytut Sztuki, Polska Akademia Nauk
}

\title{
2. The troubled image: The conflict in Northern Ireland as seen by the Irish and the British ${ }^{1}$
}

\begin{abstract}
The Troubles" - this is the name given to the conflict between Northern Ireland and Great Britain (and, in a sense, between the Irish Republic) which lasted from civil rights protests in the late 1960s up to 1998 Good Friday Agreement. The Troubles significantly dissipated political tensions in that part of Europe. However, this conflict is not only a political one but also national, economic, sectarian and cultural. The approach to this conflict defines issues of Irish identity from the northern part of the island. Cinema is also engaged in this conflict as the Troubles became the subject of films directed by both the Irish filmmakers (Pat O'Connor, Jim Sheridan, Neil Jordan, Terry George) and the British ones (Alan Clarke, Ken Loach, Mike Leigh, Paul Greengrass). The aim of this chapter is to look into these narrative patterns and to the dominating ideological attitudes present in these films.
\end{abstract}

Keywords: Northern Ireland, Troubles, Irish cinema, British cinema, conflict

\section{Introduction}

The cinematic image of the Troubles in Northern Ireland is always troubled, by definition. In all accounts concerning films about this conflict, there is persistent question: 'which side are you on?' Is it the republican or the unionist side that is supported? Is the film made from the Irish, British or Northern Irish point of view? Whose nationality makes the nationality of the film itself: the one of the director, the screenwriter, the producer or the film company? The 'identity' of these films is always disputable. The character of the two-side conflict suggests that it should be quite easy to divide films into two groups - representing prorepublican (Irish) and pro-unionist (British) narration. But it is not. The aim of this chapter is to look into these narrative patterns and to show that even though there are some dominating attitudes, their diversity is more important.

1 This publication had been completed as a part of the project British postwar social cinema financed by Narodowe Centrum Nauki (2014/13/B/HS2/02638). 
It is said the Troubles started in the late 1960s, with the protests against the discrimination of Catholic minority, and lasted until 1998, when the Good Friday Agreement was signed. The events that instigated this phase of conflict were the declaration of war between Irish Republican Army (IRA) and Ulster Volunteer Force and the civil rights march in Derry in October 1968 that was banned by the authorities and eventually evolved into riots. What happened next - the deployment of the British Army, the radicalisation and escalation of the terrorist actions on both sides, and the crucial events of the conflict, such as 'Battle of Bogside', McGurk's bar bombing along with plenty of other bomb attacks, Bloody Sunday, brutal Shankill Butchers murders and hunger strikes in Maze prison -built not only the history of the conflict but also its mythology.

Although some British film critics, as Roy Greenslade suggests ${ }^{2}$, still may have a problem with accepting the dominating cinematic image of their country's role in Northern Ireland as a cruel coloniser or occupant, it would be difficult to find a film - at least in more or less official circulation - that would openly support unionists' cause or justify Britain's politics. Even if IRA in itself is usually shown as a ruthless (even to its members) and criminal organisation, there is always a figure of a pro-republican or of an IRA member that resists the stereotype of a merciless terrorist. He (as it is always a man) feels, thinks and doubts; he ultimately doesn't believe in violence; he is a 'gentle gunman'3 - he saves the good name and represents the real face of republicanism. IRA may be defended or condemned, but there is always some understanding for it. Which cannot be said about the loyalist paramilitaries - although they hardly ever appear on screen. The main protagonist - regardless of the national origin of the production - is nearly always Irish, or republican, or nationalist. So usually these films tell the story of an Irishman as a victim of Britain, in every meaning of this word.

But the shades of this attitude may be numerous and depending on many factors, even if its core is the same. Brian McIlroy in his publication Shooting to Kill argues that "prevailing visualisation of the 'Troubles' in drama and documentary $\ldots$ is dominated by Irish nationalist and republican ideology and that the Protestant community is constantly elided by American, British and Irish filmmakers ... who prefer to accept the anti-imperialist view of Northern Ireland's existence"'.

2 See Roy Greensdale, "Editors as censors: the British press and films about Ireland," Journal of Popular British Cinema, Vol. 3 (1954), pp. 77-92.

3 See John Hill, Cinema and Northern Ireland: Film, Culture and Politics (London: British Film Institute, 2006), pp. 192, 195.

4 Brian McIlroy, Shooting to Kill: Filmmaking and the "Troubles" in Northern Ireland (Richmond: Steveston Press, 2001), p. 11. 
It's hard to disagree: cinema usually takes side of the republican cause and that is an objective observation. But writing about his growing up in Belfast, McIlroy hints at his non-Catholic background. His pro-Protestant attitude soon becomes clear - his arguments and rhetoric only confirm it. Of course, he has an unquestionable right to write in his own voice - especially that such a voice is a rare one in academic writing. But it proves, along with every account concerning films about Northern Ireland, that it is impossible to be apolitical while discussing this subject. It applies to the filmmakers too. And as this whole cinematic image seems to be rather homogenous, at least with respect to the distribution of guilt and harm, it is not that division that decides about the message, but the attitude structuring every level of the narrative.

These attitudes oscillate between the sense of wrong and the feeling of guilt associated, respectively, with the Irish and British attitudes. This pattern proves true regardless of the phase of the conflict during which particular films were made. The Irish (and/or pro-republican) attitude involves the accusation of the British authorities of their colonial cynicism. The British filmmakers admit the British guilt, but their arguments are not so much an apology to the Irish side as the condemnation of the imperial attempts of their country. The crime of imperialism, as these films say, is always a fundament of all terrorism that happens on the Northern Irish ground - no matter if it's on the republican or unionist side.

To illustrate my point, I would like to take into account a few representative films made by Irish, British or Northern Irish filmmakers and produced by Irish or British companies.

That's why I leave aside works such as '71 (2014) directed by Frenchman Yann Demange, American hits such as The Devil's Own (1997) by Alan J. Pakula or genre films just exploiting the subject, such as Resurrection Man by Marc Evans (UK, 1998). I am interested only in these films that were made during the Troubles or directly related to them. The tone and direct slant of these films fully depend on the year of production - which is probably why there was such an outburst of films in mid-1990s, when the ceasefire came into force and the peace process seriously began. These films were part of the more or less free debate on over two decades of terror.

Although it is tempting to recognise particular films as Irish or British, it is not always possible to do this. It may be clearer if the nationality of the filmmaker is self-evident and we are sure he or she is an author fully responsible for the shape of the film, which is the case of Jim Sheridan, Neil Jordan, Mike Leigh, Ken Loach or Steve McQueen. The problems begin with co-productions whereby we have to ask a question: which producer, Irish or British, shall we consider responsible for 
the overall message of the film? And what is the decisive factor concerning the provenance of the film: whether it is who is funding the film, whether what is the country of the production company or what is the nationality of the staff? And to what extent does producing the film by Irish or British institution becomes a political statement? All in all, Northern Ireland is neither Ireland nor Britain. Or maybe it is both at the same time? A similar problem emerges when we consider films made by directors who may be identified just as Northern Irish (such as Terry George, director of Some Mother's Son, 1996; Tom Collins, who made the Irish film Bogwoman, 1997; and Pearse Elliott, director of Irish/British production The Mighty Celt, 2005), and this kind of identity is a fragile one.

Nevertheless, every discussion about cinema and the Troubles must start with the founding myth - the Odd Man Out by Carol Reed (UK, 1947). This masterpiece established the whole pattern of nuanced narrative embracing ambiguity, an interplay of condemn and support, where the covert attitude opposes and dominates the overt one: we know that the main hero, Johnny, is doomed, just like his republican organisation. Still, he is the hero and the audience is somehow forced to sympathise with him, to admire his nobleness. As John Hill stresses, Odd Man Out established a pattern for subsequent Troubles' films in many other respects: it presents the view of the conflict based on fate rather than politics, it clashes public and private spheres, and it gives the whole story a form of classical tragedy.

\section{The Irish: a sense of wrong}

It is surprising how marginalised the political perspective is in the Troubles' films made by Irish directors. The republican/unionist conflict appears here as an internal affair, a purely social issue where the division line is drawn not between the society and the authorities but rather between two sides of the broken community. Both sectarian and nationalist natures of this division seem to be a forgotten source, not a real problem. We don't dwell on a religious matter and we are not given a rational or political cause of this conflict. What Irish films usually present is raw tribalism that has more in common with the sense of invincible fate and not with the explicable, sociopolitical and in consequence economic problem. This kind of attitude is particularly clear in Cal (1984) by Pat O'Connor. The dual nature of tribal conflict helps to give the film the structure of a classical tragedy. In Cal - directed by an Irishman but financed by a British company - an IRA member, Cal (John Lynch), falls in love with the Catholic wife (Helen Mirren)

5 Hill, Cinema and Northern Ireland, p. 191. 
of a Protestant policeman assassinated by him. There are no clear motives, this initial killing has no substantial meaning; it is just an incident that serves as an explanation for the impossibility of the love story. The military conflict or IRA causes are just an obstruction, a curse - Cal doesn't seem to believe in anything, he's bored and apathetic. And the failure of this love affair is not a question of sectarian, class or national differences - it's all about destiny and violence, inevitably interrelated. And it is the question of living in Northern Ireland: this place is tantamount to destiny, you can't escape or change it.

This bleak and firm conviction starts to melt down during the peace process, in mid-1990s. The social division is still overwhelming, but the films express a more optimistic attitude. Although In the Name of the Father, based on the true story of false accusations and imprisonment of 'Guildford Four' supposedly responsible for a pub bombing, is set in the middle of 1970s, its message is closely related to the climate of the 1990s. Sheridan's attitude is not yet conciliatory - not until The Boxer - it mercilessly accuses Britain and calls for justice. But at the same time, it says that the peace process must involve an honest settling of accounts between both sides: Great Britain and IRA. The main protagonists - Gerry Conlon and his father, Giuseppe (Daniel Day-Lewis and Pete Postlethwaite) - are the victims of both IRA and British authorities. The visibility of Britain's law system adds to the political character of Sheridan's film, but it is the emotional load of the family relations that decides about the film's impact. And again, it is politics that seals the heroes' destiny. And the figure of 'family' serves as a symbol for the whole Northern Irish society: it is broken by injustice and politics, both on IRA's and British side. As McIlroy stresses ${ }^{6}$, and as the very title suggests, it is the father figure that is the fundamental subject of this film. Who should the republican Belfast boy rely on? A maniac IRA commander, British authority or Giuseppe, his biological father, straight and upright, a Catholic victim of an exploiting and discriminating system? Proving the convicted innocent certifies both the moral authority of Giuseppe and the innocence of the republican cause. They become synonymous. It is not the republicanism that has to be abandoned, but the methods of terrorists.

Some Mother's Son (1996) by George (formerly involved with the Irish National Liberation Army $)^{7}$ also uses a family melodrama structure. And again, strictly political matters and tensions, this time the infamous hunger strikes of the republican prisoners in British prison, are mapped onto a family dilemmas and, as

6 See McIlroy, Shooting to Kill, pp. 76-77.

7 George co-wrote his film with Jim Sheridan and is also a co-screenwriter of In the Name of the Father and the screenwriter of The Boxer. 
a result, the film's articulation of ceasefire politics is subordinated to the modes of family and romantic melodrama with which it is interwoven ${ }^{8}$. This subordination doesn't mean the political stance is weakened in any way. Quite the contrary - the emotional impact of family distress gives the political attitude more strength. In Some Mother's Son, we watch a 'mother and son' relationship, with the mother becoming an ideologically, religiously and emotionally tinted symbol of both Mother of Christ and Mother Ireland. The strikers are almost invisible here, being vehicles for the tragedy of their mothers: Annie (Fionnula Flanagan), politically committed and fiercely supporting her son, and Kathleen (Helen Mirren), shocked by the very fact her child is into politics (or terrorism). To Kathleen, the biggest challenge is to understand and accept her son's choice and, as a consequence, to make a stand about the political struggle as well. Again, director's target is both the IRA and British justice, the latter, however, being the real source of violence. IRA appears here as both a uniting force and a threat to the local community. The difference in attitudes of Annie and Kathleen has class foundations and that tackles an important question: whose issue is the republican cause, middle or working class? In her everyday life, Kathleen, a middle-class woman, avoids the Troubles by pretending they don't exist. Annie's family experiences worse discrimination as being the lower class and Catholic at once. As such, it is more politically informed and radical. But the activities and causes of IRA are almost erased - it is not important what the strikers are accused of. They are not victims but martyrs, and this aspect is underlined by a clear Christ-like appearance of the inmates, especially the strikers' leader, Bobby Sands (John Lynch). In this light, Kathleen gains the status of Mother of Christ, with one difference: she won't let her son die and will take him out of strike. This failed martyrdom has a political and religious meaning - Ireland wants to have her children alive, regardless of IRA or Britain. That's the first step to reconciliation.

This new conciliatory tone is dominating in The Boxer, made in 1997, while the peace process reached full speed. As a repetition of a Romeo and Juliet structure, with lovers divided by the conflict (although both are on republican side), it can be compared to Cal. But here the main hero, Danny (Daniel Day-Lewis), is - in contrast with Cal - a committed and active one. This development of the protagonist may reflect the change of time: Cal was passive as he couldn't see any future for him and his love, while Danny is in the midst of the transformation of Northern Ireland and he wants to be a part of this process. It is symptomatic

8 Hill, Cinema and Northern Ireland, p. 203. 
that Britain is almost completely eliminated from this image, as if success of the ceasefire was solely the question of internal affairs.

Just like in McIlroy's observation, not only Britain is eradicated in these films, but also the Protestant side of the conflict, unexpressed and invisible. That gives an unjust impression that the Troubles concern only Catholics and republicans with victims being only on this side. There are exceptions - such as Nothing Personal (1995) made by an Irishman, Thaddeus O'Sullivan, as it gives a double portrait of both communities. But still it is just an addition, a completion of the predetermined picture, suggesting a need for a community agreement without offering an opportunity to tell a different story.

\section{The British: the sense of guilt}

Regardless of the official stand of their country, British filmmakers have never justified British military presence in Northern Ireland. It is worth debating for and to whom they direct their films. Is there an internal accusation of home authorities, an anti-imperialistic outcry or an expression of atonement or compensation for all injustice and harm done? Ken Loach in Hidden Agenda (1990), Paul Greengrass in Bloody Sunday (2002), Steve McQueen in Hunger (2008) - all of these are not much on republican or Irish side as they are fiercely against the British forces. Contact (1985) and Elephant (1989) by Alan Clarke are more puzzling cases, as they seem to distillate the very essence of the conflict. It is striking though how British filmmakers, in contrast to the Irish, avoid the private perspective to give way to a more political view.

The exception is Mike Leigh's Four Days in July (1984), a rare attempt at describing down-to-earth existence of Catholics and Protestants. Leigh shows two couples expecting babies - and the delivery date is estimated for the vulnerable days of Northern Irish community: 12th of July is the day of the Protestant parade commemorating the 1688 victory of William of Orange over the Catholic king in Battle of Boyne. During the Troubles, this annual parade often resulted in riots. In Leigh's film, despite the focus on the ordinariness of everyday life, the conflict marks everything - it's in the Catholics' small talk of life in prison and injuries suffered during the bomb attacks, and in distasteful anecdotes of Protestant soldiers about the border patrols. It is also in the narrative structure as Leigh divides the plot between two families letting them meet only in the final scene when babies are born. There is no space for peace or understanding: the children will be given purely Irish or British names, symbolically carrying the war to another generation. But equality in showing two sides doesn't reflect in director's attitude; while the Catholic couple is warm and tender for each other, 
their Protestant counterparts are cold and distanced. It is easy to believe this difference stems from the political and social tensions.

The film that is entirely concerned with politics is Hidden Agenda. Here, in contrast with the Irish cinema, the republican voice is used as a trigger for unveiling the scheming of high-profile British politicians (Loach leads the source of terrorism straight to Margaret Thatcher herself). An American couple, civil rights activists Ingrid Jessner (Frances McDormand) and Paul Sullivan (Brad Dourif) investigate the methods used by the British authorities when interrogating republican prisoners. Just after closing the case, Paul dies in an ambush, while being driven to an IRA quarters and carrying a tape with testimonies dangerous for the British state. Loach leaves out the love affair and IRA issues to focus on the British politics that has the power to break every resistance. Hidden Agenda is a political fiction drama; the events depicted cannot be taken as facts, but the mechanisms are indicated by Loach as believable and realistic.

Films by Greengrass and McQueen are based on true stories - and the ones that are the most susceptible of myth-making. Bloody Sunday recalls the events that took place in Derry, 30 January 1972, when 26 civilians were shot by British forces during the civil rights march. Greengrass uses the convention of the documentary style, covering 24 hours of this ill-fated day. The protesters were Catholic, but their leader, MP Ivan Cooper (James Nesbitt) was a Protestant. What we see here is a bleak, detailed re-enactment of the events, with the chaos, horror and disbelief that accompanied them. Greengrass makes his style austere, but he cannot escape aestheticisation of image and, in consequence, the whole story. The disorder in the frame builds the tension but the good/bad division drawn here is clear. It is the conflict between British and Northern Irish, with the result already determined. The juxtaposition of personal tragedies with the uniformed military actions only deepens the feeling of guilt. But the soldiers have human faces too, and just like in Irish films, republicans were the victims of both IRA and British authorities; here these army boys are victims of their government, thrown in a war they don't really understand or accept. Greengrass' usage of documentary convention somehow legitimises his vision of Bloody Sunday. The ending credits informing the audience reporting the legal actions after this 'Bogside Massacre' and informing that British army bore no consequences for this operation give this depiction a powerful credibility.

While McQueen comes back to the historical events as well, he goes away as far as he can from any documentary convention. To some extent, Hunger recreates the 1981 dirt and hunger strikes, but its idea is to re-imagine the horror of it and not to bring back sheer facts. In contrast to George using the strike as an excuse for the universal narrative, McQueen focuses on it entirely, showing in hypnotising, 
visually sophisticated frames, and shots all the sensual and physical aspects of dirt protests and of suffering hunger. But here Bobby Sands is not the one known from the imagery spread in republican mythology. With the face and body of Michael Fassbender, he becomes a modern, universal figure, taken out from the historical context. But Greengrass, although distancing himself from political accusation, repeats George's strategy in one respect - torture and dying of Bobby Sands is presented like in The Passion of the Christ and this trope determines the meaning of Hunger. The camera caresses every wound, worships the weakening and finally deceasing Sands' body, fitting perfectly in the religious imaginary of republican martyrdom.

McQueen's film is entirely visual, with almost no dialogues. There is, however, one scene set in the middle of the film, breaking this coherence and establishing the centre of gravity. It is the conversation between Sands and the priest, explaining the motivation, consciousness and consequences of the striker's decision of starving himself to death. The reductive minimalism of the set adds to the intensity of words. This dialogue has also religious undertones - in both content and form (Bobby's tale as a parable). It echoes a similar moment from Odd Man Out when Jimmy's girlfriend talks to the priest expressing firmly her stance about Jimmy and the doomed fate of the Organisation's cause. McQueen's film may be seen as incoherent and too formalistic ${ }^{9}$, but it accomplishes an important aim: it attributes the republican cause with a dignity of an almost mystical nature.

In the films by Alan Clarke, there is no dignity at all either in the terrorism or in the fight against it. Clarke, quite surprisingly, given his social realist background, moves towards somehow experimental minimalism. Contact, an adaptation of a once controversial book by Anthony (AFN) Clarke, depicts the routine of British border patrols in Northern Ireland. The director abandons most of the narrative communicativeness of the book leaving just sheer repetitiveness of tours and hunting for unnamed enemy - local terrorists. Narrative information is radically reduced - the dialogue is scarce, we know nothing about the reason of this hunt or psychological motivation of the soldiers. The result is the sense of complete alienation and danger, the reification of fight. This almost behavioural depiction of conflict - from the British perspective - results in a painful question: what is this absurdity about and what are these people (British soldiers) doing here? This question relates both to the narrative and to the conflict in general. Elephant is even more radical as it rejects any narrative. It shows eighteen executions carried by unspecified terrorists - the film consists only of walking and killing, shocking

9 See Tony Rayns, “Hunger," SightðSound, Vol. 18, No. 11 (2008), p. 63. 
in their dull repetitiveness, with no commentary in words or images. The last execution breaks the pattern and wakes up the hypnotised viewer unexpectedly building up an ambiguity of interpretation. Clarke avoids any clear attitude, he's just giving the visual material - the viewers have to decide for themselves.

\section{Other voices}

All of these films were directed by men. And although sometimes they focus on women's experience, the frame perspective is always male. There are a few exceptions though: one of them may be Margo Harkin's Hush-a-Bye Baby (1990), a story about a pregnant teenage girl whose boyfriend is serving a sentence in a British prison. But it is Maeve (1983) directed by Pat Murphy that expresses not only female but also a feminist point of view. It doesn't mean the film is didactic in any sense there is no edifying immediacy here. Murphy presents life in its fluency - as a series of contradictions, choices, a process of engagement and work ${ }^{10}$. She engages various modes of storytelling, equalising life experience with storytelling itself and opening the film structure; the present, the past, reality and myths, all of them entwined. Maeve leaves Belfast and leaves the Troubles. She is haunted by it, but her stance is firm - the conflict is something external, and she opposes it by rejecting any participation in it. That forms her feminism and distinguishes her from typical imagining of a woman in Troubles' narratives as a 'mother of us all'11. This kind of feminism is inevitable as there is a total lack of common ground or space for interaction between republican interests and the feminist cause ${ }^{12}$.

As most of the Troubles' films focus on the conflict, there is only one, I suppose, that gives all attention to the place itself. In I am Belfast (2015), a film essay by Mark Cousins, Belfast is an elderly woman talking with the director and showing him her own space, independent and proud, though traumatised. Although Cousins' work isn't specifically about the Troubles, it lies in the centre of the story as the time of destruction for both the place and the community. What is more important, Cousins, born in Belfast, seems to be the only director that restrains from indicating the guilty side and says: we do it to ourselves. Like in the scene when She-Belfast tells the story of how birds were eating human flesh scattered on the streets after the bombing. She is asking: are we just meat for each other? It's not about the reconciliation, it's about the communal therapy.

10 Janet Hawken, “Maeve,” Undercut, No. 6 (1982-1983), p. 8.

11 See Hill, Cinema and Northern Ireland, pp. 236-242.

12 Hawken, “Maeve," p. 9. 
This tone of I am Belfast may be possible in 2015, when the narrative of the Troubles is in a way closed and the new one, concerning life after the conflict, opens up. One may expect these new accounts would be equally traumatic as the earlier ones, for both the Irish and the British, and especially for the Northern Irish community. The lack of military conflict doesn't mean the end of the Troubles. The violence was, paradoxically, offering a meaning of life for so many. The new essence is still in the process of emerging and needs new ways of cinematic imagining.

\section{Bibliography}

Greensdale, Roy. "Editors as censors: the British press and films about Ireland." Journal of Popular British Cinema, Vol. 3, 2000, pp. 77-92.

Hawken, Janet. “Maeve." Undercut, No. 6, 1982-1983, pp. 8-9.

Hill, John. Cinema and Northern Ireland: Film, Culture and Politics. London: British Film Institute, 2006.

Mcllroy, Brian. Shooting to Kill: Filmmaking and the "Troubles" in Northern Ireland. Richmond: Steveston Press, 2001.

Rayns, Tony. “Hunger." SighteSound, Vol. 18, No. 11, 2008, pp. 63. 



\title{
Katixa Agirre \\ NOR Research Group, University of the Basque Country (UPV/EHU) \\ 3. Are they terrorists or victims? Basque cinema, violence and memory
}

\begin{abstract}
Basque cinema from the last decade has apparently neglected political conflict and recent violence. The film Lasa eta Zabala (2014), by Pablo Malo, is one of the exceptional cases in which Basque recent violent past is revisited on-screen. Starting in 1983, it tells the real story of two young ETA (Euskadi Ta Askatasuna) militants who are refugees in the French Basque Country and are soon to become the first two official victims of the GAL (Grupos Antiterroristas de Liberacion), the state-sponsored death squad that killed 27 people between 1983 and 1987. Lasa and Zabala were kidnapped, tortured for months, and then executed and buried. Lasa eta Zabala engages with a difficult topic, since it tells the story of two victims that were originally - and according to the official memory - terrorists, and their executioners were civil guards, the police force that was for years ETA's primary target.

Based on an in-depth interview with the screenwriter, in this chapter, I present Lasa eta Zabala as a flawed contribution toward a historical memory. Knowing the controversial material they are dealing with, screenwriter and director deploy different strategies to make their film less inflammatory, but the result is incoherent and confusing. As many authors (Labanyi, Crumbaugh, and Verdery) have noted when reflecting on the Spanish civil war and Franco regime's victims, Lasa eta Zabala also decontextualizes political violence, emphasizing the role of the victims, but at the end it ends up being too cautious to really go into the reasons and consequences of these brutal acts.
\end{abstract}

Keywords: Cinema, memory, terrorism, victims, Basque conflict

\section{Basque cinema and historical memory}

In the last decade, Basque cinema has emerged and bloomed. After 12 years of silence, A upa Etxebeste! [Hooray for Etxebeste!] (2005), a comedy shot integrally in Basque language, was released with notable audience success, prompting a humble but steady production flux of Basque films. Coincidentally, the first years of the twenty-first century have also opened a new political cycle in the Basque Country, after the much-awaited decision of separatist group ETA (Euskadi Ta Askatasuna) to put an end to decades of violence. This context has put a new political focus on the necessity of some sort of "grand narrative" to help Basque society understand and remember its violent past. 
It could be expected that these two circumstances - a revitalized Basque cinema and a symbolic battle over the past - would somehow overlap, with films contributing to the task of a narrative-building about the past. However, this is only partially true. Compared to the effervescent post-Franco era in which a thriving cinema industry engaged with a nation-building intent via subsidized cinema (Stone and Rodriguez, 2015: 64), Basque cinema of the twenty-first century has changed its focus and style. On the one hand, the use of Basque language is for the first time in history regular and more natural now. On the other hand, these new films have shifted "its discourse from the violence that marks so much earlier Basque cinema to class, gender, and sexual struggles," ${ }^{1}$ and in general, they have not shown a great interest in the conflictive and violent past.

Indeed, reflection on the Basque conflict has been present in documentary films but it is scarce when it comes to fiction movies. Actually the two more successful films of this last decade of Basque cinema are a comedy: the aforementioned Aupa Etxebeste!, which still holds the box office record among Basque-speaking films, and an exquisite drama - Loreak [Flowers]-, which along with a general critical acclaim was submitted to the Oscars race representing Spain in 2015.

Stone and Rodriguez have pointed at a shift from a cinema of citizens to a cinema of sentiment, ${ }^{2}$ following a global trend that diffuses nationhood - and therefore the nation-building role of cinema - and highlights personhood. As they put it, "contemporary Basque cinema is a cinema of sentiment in which the Basqueness of the protagonist is a detail that does not determine the events of the film."3

However, in this chapter, I would like to discuss a particular film that can be considered an exception inside this new wave of Basque cinema, and indeed an exception to this cinema of sentiment. That film is Lasa eta Zabala, a 2014 movie written by Joanes Urkixo and directed by Pablo Malo.

Lasa eta Zabala can be considered an exception; first from a genre perspective, because this film is a legal thriller based on an actual violent episode. Thriller is perhaps the most neglected genre in this new wave of Basque cinema, more inclined to produce comedies, dramas, and documentaries. But more importantly, as Lasa eta Zabala is set in the 1980s and 1990s, it can be considered a historical film, a movie that openly seeks to contribute to the debate about memory of the recent violent past in the Basque Country.

1 José Colmeiro, Joseba Gabilondo, "Negotiating the local and the global," in A Companion to Spanish Cinema, eds. Jo Labanyi and Tatiana Pavlović (Oxford: Blackwell Publishing Ltd., 2012), pp. 94.

2 Colmeiro, Gabilondo, "Negotiating the local," p. 9.

3 Colmeiro, Gabilondo, "Negotiating the local," p. 10. 
The film tells the actual and well-known story of two young ETA militants who became the first victims of the GAL (Grupos Antiterroristas de Liberacion), the state-sponsored death squad that killed 27 people in the 1980s. In October 1983, Joxean Lasa and Josi Zabala, who were political refugees in the French Basque Country, were kidnapped by civil guards, tortured, and then executed. Their bodies, buried in southern Spain, were not identified until the mid-nineties.

Some authors have described Basque cinema of previous decades as sympathetic to ETA (de Pablo, 2014: 200), linked to the social support that the group still held in the post-Franco time. This support declined dramatically over the years, ${ }^{4}$ and now that ETA is politically and morally defeated, Lasa and Zabala's scandalous case is a difficult topic to engage with: it tells the story of two victims that were originally, and according to the official narrative, terrorists.

And this difficulty, I would contend, is one that the filmmakers have not been able to resolve satisfactorily. Based on an in-depth interview with the screenwriter and promoter of the film, Joanes Urkixo, ${ }^{5}$ together with a film analysis, I will try to explain why I think Lasa eta Zabala is, sadly enough, a flawed contribution to historical memory, drawing on three main reasons: ideological and stylistic discrepancies between screenwriter and director, a desire to avoid any controversy, and an excessive emphasis on the figure of the victim. By doing so, my goal is to exemplify why Basque conflict and the project for a historical memory via cinema is still a challenging and largely uncompleted mission.

\section{Two episodes, two sides, two views}

The project of bringing this terrible story to the screen was first conceived by screenwriter Joanes Urkixo as a two-episode miniseries, but EiTB (Euskal Irrati Telebista), the Basque Public Broadcasting Group, requested a film after the project was pitched. According to the screenwriter, the original idea would count with two main characters. In the first episode, the main character would be Jesús García, an actual police officer who promoted the investigation about two bodies that would be later identified as those of Lasa and Zabala's. The second episode would be led by Iñigo, based on the actual lawyer Iñigo Iruin, who ran the

4 Rafael Leonisio, Raúl López, "Between fear, indignation and indifference. Basque public opinion and socio-political behavior facing terrorism," in ETA's Terrorist Campaign: From Violence to Politics, 1968-2015, eds. Rafael Leonisio, Fernando Molina, and Diego Muro (Oxford: Routledge, 2017), p. 148.

5 This interview took place in Bilbao, 14 July 2015, and was later completed via e-mail and phone. 
investigation and trial of the murders. Once converted into a full-length film, the actual protagonist happens to be Iñigo, the lawyer, while Jesus García only leads a couple of scenes at the beginning. I contend that both characters are actually one, namely, the impersonation of justice and integrity. Just in case we miss the point, both have extremely similar and explicit conversations at two different points of the film.

When Jesus García exits the judge's office, after convincing him to open the case for the found bodies in Alicante, he is confronted by a civil guard. According to this man, García is working in favor of those who would not "hesitate to shoot us both if they had the chance." And when he asks: "Which side are you on?" García replies: "on the side of justice and duty, and so you should be, in case you've forgotten." Also Iñigo the lawyer, later on, has a similar conversation with Fede, his assistant, about the convenience of making a witness commit perjury to win the case. But Fede states, and Iñigo concurs, that breaking the law that way is behaving like them, those who have committed terrible crimes. Their side is that of justice, not revenge.

In both conversations, the idea of the two sides is stressed. But these two sides are not ETA versus GAL, or terrorists versus law enforcement, nor even freedom militants versus corrupt police officers, but rather, justice versus injustice. According to this idea, Iñigo and officer García are on the same side, despite the fact that they are in different contexts, have different ideologies, and even speak different languages. In other words, Iñigo defends ETA militants in court and Jesús García is a police authority fighting ETA, but both are, according to the film, on the same side, since both are working for justice.

This idea, although politically correct, seems at odds with the historical context in which the film is set, and it is actually denied by another sequence of the film, that is, the opening scene. This pre-credit scene is set in 2013 and represents Lasa and Zabala's sisters, now middle-aged, being interviewed in the radio. The radio presenter brings out the "sides" issues, but he does it this way: "Thirty years are gone since the killing of your brothers and now it seems possible for victims of both sides to come together and share experiences" [the emphasis is mine]. And the actress who impersonates Pili Zabala, insists on the same idea: "All of us, from both sides, have justified many injustices."

So there were actually two sides, but they were not the justice/injustice sides that Iñigo and Jesús desired for, but rather two sides at war, justifying and committing injustices equally, according to the radio interview that opens the film.

This radio interview with the victims' sisters is short and only appears before the credits. It is set in the present, unlike the rest of the film; its style and pace 
differ from the other thriller-like scenes; and the characters never appear again. It is certainly a strange sequence, but the screenwriter explained me the reasons. In the original script, the relevance of this interview was much bigger. It was actually the common thread of the film, and it was through the voices of the sisters that the actions unfolded. But the director, Pablo Malo, disagreed with this narrative device and reduced the radio interview to one short scene that would work only as an epilogue. In the last moment, while editing, he decided to make it a prologue instead.

The radio interview was one of the many issues in which the director's and screenwriter's views collided. As it ended being, the radio interview is incoherent inside this film, not only formally but also ideologically, as the different approach to the "both sides" issue shows.

The differences between the director and the screenwriter can be boiled down to one: their aims were different. Always according to the Urkixo, "reconciliation was not Pablo's fight, he always saw the film as a thriller, period." That's why the radio interview and its explicit and ideological message bothered Pablo Malo. He wanted to build a pure thriller, without sending further political messages.

Sticking to the facts did not seem difficult, since, apart from all the necessary elements (violence, conspiracies, seeking of justice by heroes, etc.), this case was one of the very few state terrorism cases that was trialed, and it is therefore very well documented.

\section{The judicial truth as a half lie}

The judicial record of the case was actually one of the main reasons to pick up this story. According to Urkixo, the trial and the sentences were some kind of "safety net" they counted on, since they were going to put on the table a very sensitive and therefore controversial topic. Pablo Malo himself has repeated in every interview that the film is based "on facts proven, judged, and ratified by international courts."

The fear is understandable since the attacks that director Julio Medem faced when he released La pelota vasca, la piel contra la piedra (2003), a documentary about the Basque conflict, were still fresh in the memory. Medem's film, which portrayed not only ETA victims, but also GAL and torture victims, was fiercely attacked by right-wing parties, many media outlets, and some ETA victims' associations, including boycotts, demonstrations, and petitions of withdrawal from the San Sebastian International Film Festival?

6 Rocío García, “Lasa y Zabala, la polémica llega al cine” El País, 14 September 2014.

7 Stone, Rob. Julio Medem. Manchester: Manchester University Press, 2007. P. 229 
To understand this hysteria, it is worth bringing up an idea that Justin Crumbaugh has posed in a different context, that of the Francoist victims in contemporary Spain. That idea is that victims are used as a means of disqualifying opponents' agendas. ETA victims and their political use are a great example of this symbolic dispute. For the Spanish right-wing party, the Partido Popular (PP), ETA victims "have been the perfect tool to transpose historical culpability (from Franco to ETA)." ${ }^{\prime \prime}$ Therefore, when "Franco's victims become publicly constituted as victims, they implicitly enter into an imagined dialogue with the victims of ETA."

If Franco's victims are a potential challenge to the conservative monopoly over victimhood itself, the question becomes even trickier when it comes to ETA militants who are themselves victims of state terrorism. This was the kind of challenge that a film like Lasa eta Zabala might have posed and the danger the filmmakers feared. After all the film flips the victim/terrorist roles: the victims of this case are ETA militants, and they are kidnapped, tortured, and made disappeared by civil guards, historically, the police force that has been a prime target for ETA. That is why the film is so cautious. They stick to the judicial record and rely on the new peace scenario we live in today for a pacific release of the film, a scenario that Medem could not count on when he premiered his risky film.

The screenwriter always knew that he was going to base his story on the judicial record. And he stuck to his decision rigidly. Consequently, outside the judicial truth there is nothing: no interpretation, no speculation, and no wider context. At the end, only one moral message: every victim of every political violence is a victim from the same side, the evil side.

And it is precisely under these two premises: to speak only about what was proved in court and the mantra that "every victim is equal" that the film loses consistency and coherence. It seems quite obvious to say this but the judicial truth is only one part of reality, it can only refer to the facts that were proved and ratified, and when presented isolated, as the film does, they sometimes become incomprehensible, if not bizarre. Many things could not be proved then. The most palpable one is the question about the involvement of the government in the creation, funding, and promotion of the GAL. In the film, Galindo, the infamous colonel in charge of the death squad, tells his men, before committing the crimes: "we've received an order from the government of the nation." And then he repeats: "keep in mind that we work with official backup, we're working with a safety net here."

8 Justin Crumbaugh, "Are we all (still) Miguel Ángel Blanco? Victimhood, the media afterlife, and the challenge for historical memory," Hispanic Review, Vol. 75, No. 4 (2007), p. 368.

9 Crumbaugh, “Are we all (still) Miguel Ángel Blanco?”, p. 367. 
But this is the only reference to a government responsibility for the crimes, the rest of the film avoids this question in a disconcerting way. At one point of the lawyer's investigation, Iñigo is working on a blackboard, trying to build a pyramid of the death squad organization. On top of it, there is a big X. In the final version of the script, as the screenwriter told me, this $\mathrm{X}$ had some relevance, and Iñigo referred to it with the next line: "It's too high, I cannot reach it." But during the shooting, and based on atrezzo problems, the director decided to suppress that line and the $\mathrm{X}$ is almost imperceptible for the viewer. This $\mathrm{X}$ is important because it is a direct reference to $\mathrm{Mr}$. $\mathrm{X}$, as the media and the popular imaginary knew Felipe González, the former president of Spain (1982-1996). Although it remains a mystery today who the person on top of the GAL was, many point their fingers to González, and this case, together with other corruption scandals, costed him his position in 1996.

But, in the film, besides Galindo's initial words and the discreet $\mathrm{X}$ on the blackboard, the film sidesteps the question of the government connection with the crimes in a rather cautious way.

I would like to argue that with this blatant omission, the film becomes incomprehensible for a viewer without previous knowledge about it. According to the story we see on-screen, some civil guards are chosen to "stab ETA on the neck" but they must do it outside the law. The reason for it is never explained. At one point Galindo describes the task ahead: "we need to go to France and do the same things we do here but not legally, because that is not possible." From this line one could infer that in Spain it is actually legal to kidnap, torture, and execute someone, making the body disappear afterward. In the film, the role of France is never explained, and we never learn why Lasa and Zabala have, together with other comrades, refugee status in the neighbor country.

Surprisingly enough, once atrocities are committed - the film is quite explicit in this respect - the state responds according to the law, even though it has been suggested that the state is behind the crimes. There are some aggressions and threats to witnesses, and also a bomb is sent to Iñigo the lawyer, an incident in which his assistant Fede dies; but all these acts are committed by civil guards individually. On the part of the state, there is no pressure, no refusing to collaborate, and the film also forgets the eloquent fact that Colonel Galindo was promoted to general in 1995 by the González government, when he was already on the spot for this case.

The response of the state, as represented in this film, seems nothing but democratic and exemplary. That is why there is another scene that looks, again, quite out of this context. I am referring here to the scene at the cemetery. 
After 12 years missing, the bodies of Lasa and Zabala finally return home for a proper burial. Family and friends await at the gates of the cemetery. A strong police detachment guards the gates. Tension grows as orders arrive saying that only close relatives can enter the cemetery. There are insults and protests, and although Iñigo tries to mediate for a peaceful resolution, finally the police baton charges people gathered around the cemetery.

Even though this is not a key scene from a narrative point of view, I think it is very telling of the limitations of the film. Isolated from its political and social context, only showing patches of chaos and violence and with a poor mise-en-scène, it is a great example of how the representation of a past incident can be completely ahistorical, if the connections between facts and acts are never explained. One cannot help but see the director's reluctance in the poor way the cemetery scene is directed. Again, for the viewer with no previous knowledge of the case, it is difficult to understand why the Basque autonomous police is attacking the families gathered for such a tragic occasion. This is the consequence of omitting the context of political tension and violence of the 1990s in the Basque Country, in which the Basque police was "dealing with a low-intensity war." ${ }^{10}$ Regarding the mise-en-scène, although we see the date of the incident on screen - June 1996 - actors and extras are shot wearing heavy coats and the atmosphere is nothing but gray and obviously wintery. Just a small detail that reveals the sloppy way the scene is directed.

Finally, and as a relative "happy ending" for the hero, Iñigo, the sentences are very high for the civil guards involved. Iñigo takes the sentence to the cemetery, where Fede is buried. Iñigo has had to pay a high token, but, as it is suggested for a moment, justice has been lastly done. But wait, just before the final credits roll up, Iñigo's voice-over recalls that Bayo and Dorado, as authors, only served 6 years of the 67 they were convicted, and Galindo and Elgorriaga, convicted as instigators to 75 years in prison, only served 4 and 1 years each. Who reduced their sentences and why? The film does not talk about it.

\section{Are all victims equal?}

The movie tells us very little about Lasa and Zabala. There are a couple of scenes at the beginning in which we see the two young men in their daily routine as political refugees in the French Basque Country. Their connection to ETA is never explained. In reality, the only action Lasa and Zabala took as ETA members was an attempt to rob a bank. Apart from this first minutes of the film, we only see Lasa

10 Paddy Woodworth, Dirty War, Clean Hands: ETA, the GAL and Spanish Democracy (New Haven and London: Yale University Press, 2002), p. 285. 
and Zabala as victims. They are violently kidnapped, savagely tortured, and then driven $800 \mathrm{~km}$ in the trunk of a car to be, on arrival, shot in the head and buried in quicklime. The representation of these events is explicit, to the point that Lasa and Zabala's parents were prevented from watching the film.

Of course, if we only read this film as a thriller, we do not really need to know much more about the victims, they are there so evil can deploy its power, and they also give the hero a motive to pursue justice. From a historical memory perspective, however, I think showing Lasa and Zabala's terrible suffering is not enough. The problem here is to fall into the kind of issues that Crumbaugh identified when talking about Franco victims, some kind of contest to determine who suffered more and who consequently deserves our memory and attention. In this macabre contest, the film tries to suggest that there is a tie. Everybody suffered, all this was a nonsense, and it is good that we have moved on. This is more or less the message we get from the radio interview. That is why I think the film leans toward what historian Ricard Vinyes has described as simple ecumenism. Simple ecumenism suggests that every dead, tortured, and offended are equal. This being empirically true, turns out to be useless and disconcerting from a historical perspective. According to this vision, the war is "a bunch of confrontation techniques and not the prolongation of social and political relations."

With the idea of both sides - justice and injustice, those who commit crimes and those who suffer them - the film falls into the simple ecumenism described by Vinyes. The story focuses on the victims, the two young boys, but we know nothing about them besides their victim roles. Occasionally, we also see other victims fall: there are seven references to ETA crimes during the film, and we see how the GAL also kills other refugees in the French Basque Country, following the confessions made by Lasa and Zabala during torture. The opening credits, with a Hitchcockian touch, refer to the "years of lead," as the deadliest years of ETA are known: they show car explosions, chaos, and street violence. But everything appears mixed on-screen, lacking any connection or interpretative intent.

This ideological asepsis might very well be interpreted as lack of courage. Reality reminds us that not all victims are equal, or at least not all victims are treated equally. In the summer of 2015, a Spanish court ratified the Ministry of Interior's decision to refuse compensation to GAL victims if they had themselves participated in organized crime. On the same line, only a few months earlier, a pacifist event that was going to take place in the Congress of Spain, and in which victims of ETA and GAL were going to take part together, was vetoed by the two main political parties, PP (Partido Popular) and PSOE (Partido Socialista Obrero Español). Even more recently, the unstable identity of GAL victims was 
put on the table at prime time: during a televised debate prior to the last Basque Government elections, in September 2016, Pili Zabala, one of Zabala's sisters and now running for lehendakari (president of the Basque government) was denied her victim condition by another candidate, that of the PP, Alfonso Alonso. This tense anecdote - Zabala sent Alonso a frosty stare that made him babbled was the highlight of the TV debate, profusely commented on social media and discussed by every political party.

\section{Conclusion}

It is obvious that the film dealt with a highly inflammable material, even from a contemporary perspective. Unfortunately, the attempt ended up caught in its own contradictions and limitations.

The alleged intention of both producer and screenwriter was to send "a political message of memory and reconciliation." But at the same time, they commissioned the project to a director known for his thrillers and his ideological neutrality. "We chose him because he was not politically marked" said Urkixo. Predictably, this director reduced the political content and emphasized the thriller tone of the story, but let the story halfway. If it is a thriller, there are many avoidable scenes - like the radio interview -, if it really wants to talk about historical memory, a wider context is required. But screenwriter's and director's erratic movements to reach a compromise decontextualized violence and isolated this particular case, making a poor contribution to historical memory, and also, if I might say, a poor thriller.

But there is a problem in the original script as well: strictly sticking to the judicial record narrows the focus so much that many of the narrated things seem incomprehensible, if not grotesque.

I believe that our violent past deserves more audacity and more confidence in a mature viewer, a viewer able to understand that, beyond all the respect that any victim deserves, contextualizing and establishing connections does not mean to justify violence. As I see it, a more audacious approach would have been an invitation to a deeper reflection on violence, its causes and consequences.

The new wave of Basque cinema is focusing on making more personal films and, with the mentioned exceptions, sidestepping the question of historical memory/ memories. I suspect there is some kind of exhaustion behind this artistic trend: Basque conflict has been an overwhelming and suffocating issue for too many decades in the Basque Country. But there is also a limit to freedom of speech, and controversy will haunt every film that defies the official narrative. But controversy, even boycott, is a danger that requires courage. We need to come to terms with the fact that denial or self-censorship will not be the path to follow. As Jo Labanyi has stated 
when speaking about the Francoist victims, "there is no one historical memory but rather a conflict of memories."11 The same goes for the Basque conflict. Cinema should acknowledge this conflict of memories, not refuse it, if it wishes to become an agent of the project for a sincere historical memory and a true reconciliation.

\section{Bibliography}

Colmeiro, José and Gabilondo, Joseba. "Negotiating the local and the global." In: A Companion to Spanish Cinema, eds. Jo Labanyi and Tatiana Pavlović. Oxford: Blackwell Publishing Ltd., 2012, pp. 81-110.

Crumbaugh, Justin. "Are we all (still) Miguel Ángel Blanco? Victimhood, the media afterlife, and the challenge for historical memory." Hispanic Review, Vol. 75, No. 4, 2007, pp. 365-384.

de Pablo, Santiago. "Cine y nacionalismo vasco: el caso de ETA político-militar y Euskadiko Ezkerra." In: Hacer historia con imágenes, eds. Hueso Montón and Camarero Gómez. Madrid: Síntesis, 2014, pp. 199-220.

García, Rocío. “Lasa y Zabala, la polémica llega al cine.” El País, 14.09.2014.

Labanyi, Jo. "Historias de víctimas: la memoria histórica y el testimonio en la España contemporánea." Iberoamericana, Vol. 6, No. 24, 2006, pp. 87-98.

Leonisio, Rafael and López, Raúl. "Between fear, indignation and indifference. Basque public opinion and socio-political behavior facing terrorism." In: ETA's Terrorist Campaign: From Violence to Politics, 1968-2015, eds. Rafael Leonisio, Fernando Molina, and Diego Muro. Oxford: Routledge, 2017, pp. 143-161.

Marull, David Ruiz. "Feliz González: Nunca hemos tenido peor resultado en el País Vasco pese a las cosas que hicimos," La Vanguardia, 2016. 07 December 2016. http://www.lavanguardia.com/politica/20160928/41635221724/felipegonzalez-pais-vasco-gal.html.

Millás, Juan José. “Pude volar a la cúpula de ETA," El País, 2010. 17 August 2016. http://elpais.com/diario/2010/11/07/domingo/1289105554_850215.html

Stone, Rob. Julio Medem. Manchester: Manchester University Press, 2007.

Stone, Rob and Rodríguez, María Pilar. Basque Cinema: A Cultural and Political History. London: IB Tauris, 2015.

Vinyes, Ricard. "La reconciliación como ideología." El País, 12.08.2010.

Woodworth, Paddy. Dirty War, Clean Hands: ETA, the GAL and Spanish Democracy. New Haven and London: Yale University Press, 2002.

11 Labanyi, Jo . "Historias de víctimas: la memoria histórica y el testimonio en la España contemporánea." Iberoamericana, Vol. 6, No. 24, 2006, p. 89. 

Gorka Etxebarria and Josu Martinez

University of the Basque Country

\title{
4. A traditional stereotype for modern Spanish politics: The Basque pro-independence coalition Herri Batasuna and its depiction in cinema
}

\begin{abstract}
This chapter shows an approach to national stereotypes in the Basque Country, through four different films. It analyses how the pro-independence coalition Herri Batasuna (People's Unity) was portrayed in films in which their plots took place in the 1980s. We propose that its characterisation is ruralised, traditional and irrational, and is built in connection with the new Spanish modern-democratic identity, as its opposite pole.
\end{abstract}

Keywords: National identities, cinema stereotypes, Basque nationalism, 1980s

The aim of this chapter is to propose an interpretation about how the Basque cinema has dealt with national stereotypes in the Basque Country. For that purpose, we will analyse how the Basque pro-independence coalition Herri Batasuna (People's Unity) has been portrayed in four different films.

Herri Batasuna was formed in 1978, opposed to the approval of the Spanish Constitution. Three years after Franco's death, the Constitution was negotiated among the former Francoist government and the opposition parties that were elected in June 1977. It established the continuity of the Francoist monarchy, the Army, police forces and administration, but assured the multi-party election system and the human and civil rights.

Herri Batasuna characterised the very same Constitution as anti-Basque and antiworkers, arguing that it did not accept Basque people's right for self-determination and that it declared capitalism as the only possible economic system. From the beginning, Herri Batasuna assumed a violent campaign of ETA (Euskadi Ta Askatasuna, Basque Country and Freedom) and supported armed organisation's militants and prisoners.

ETA was an armed organisation founded in 1959. During Francoism, influenced by Cypriot and Algerian independence, and Cuban Revolution, they pretended to encourage a revolutionary mass movement towards an independent and socialist Basque Country. After Franco's death, ETA escalated its killing action, in search for what they called a real breakup with the dictatorship. ${ }^{1}$

1 José María Garmendia, Historia de ETA (Donostia: Haranburu, 1996); Francisco Letamendia, Historia del nacionalismo vasco y de ETA (San Sebastián: R\&B, 1994); José 
In January 1978, ETA announced a five-point programme that included the conditions for a ceasefire: 1) amnesty for political prisoners, 2) legalisation of every political party (pro-independence parties were not legal), 3) expulsion of former-Francoist police forces from the Basque territory, 4) approval of the working and popular classes' concerns as expressed by their own organisations, and 5) an autonomous government for the Basque Country with the control over Spanish Army in the territory and the right to organise an independence referendum.

The five points were an updated statement from the one presented in 1976: the KAS Alternative (Koordinadora Abertzale Sozialista, Patriotic Socialist Coordination). That alternative was felt as a common-sense proposal, because most opposition parties accepted those terms in 1976. But the situation had changed after the first multi-party elections in 1977, and especially once the Constitution was accepted.

During the 1980s, Herri Batasuna refused to participate in the Spanish parliament or any autonomous parliament, unless the KAS Alternative was accepted by the government. This was a decade led by the political leaders that emerged during the last years of Francoism. In that sense, the 1980s were the context in which a generation that had been politically brought up during the dictatorial rule landed in a Constitutional Monarchy. Both ETA and Herri Batasuna understood that the political reform, led by Francoist government, ended in a covered dictatorship. However, the rest of anti-Francoist main parties accepted the Constitution as the best democracy that could have been achieved.

That is why we have chosen films in which their plot takes place in the 1980s: Erreporteroak (The Reporter, Iñaki Aizpuru, 1983), La muerte de Mikel (Mikel's Death, Imanol Uribe, 1984), Ke arteko egunak (Smoky Days, Antxon Ezeiza, 1989), and Yoyes (Helena Taberna, 2000). As can be noticed, the films are from different epochs. Hence, we should analyse each of the films related to their own historical context.

The main political difference in the 1980s was about the essence of the Constitutional Monarchy established in 1978: democracy for most, but covered dictatorship for some. Herri Batasuna contested elections in 1979 for the first time, and their big support in the Basque Country surprised the Spanish public opinion. That difference between the Basque Country and the Spanish public opinion has a lot to do with the national issue, as we will see.

Félix Azurmendi, ETA de principio a fin. Crónica documentada de un relato (Donostia: Ttartalo, 2014). 
That is to say, we will see how stereotypes on national characters were used and which characteristics were added to each national identity, through the chosen films. We will argue that Herri Batasuna was conceptualised as the negative pole in relation with the new Spain that aroused after 40 years of military and conservative dictatorship.

In that sense, another principal idea we will defend is that national identities are built and reproduced in a metaphoric dialogue with other nations. A national definition, as any definition, implies a differentiation. That is to say, to be part of a nation, France for instance, means the denial of the French being German, English, Spanish, etc. The national identity is part of a dynamic process that includes a self-identification (a definition of one's nation) and a categorisation of the others (usually neighbour nations). In other words, every nation is defined in relation to other nations. ${ }^{2}$

Thereby, we will deal with both the self-definition process and the categorisation of the other process regarding national identity that took place in post-Franco Spain, and specially, in the Basque Country. We have to be aware of both national identities, if we want to understand how national stereotypes are reproduced through the cinema, and, also, how the cinema dealt with the exceptional situation in the Basque Country.

We must remember that Basque society has been exposed to a dual national interpellation since the end of the nineteenth century, when Basque nationalism appeared as a political movement. It was a fin de siècle bourgeois-racialist, antisocialist and ultra-catholic movement in its beginnings, in the vein of French Barresianism and German völkisch movement. ${ }^{3}$ During the first third of the twentieth century, the Basque national identity spread out from its initial narrowness, and different liberal and even leftist political parties defined themselves as nationally Basque. ${ }^{4}$

2 Juan García, "Nación, identidad y paradoja. Una perspectiva relacional para el estudio del nacionalismo," Reis: Revista española de investigaciones sociológicas, No. 67 (1994), pp. 165-186; Chris Lorenz, "Representations of Identity: Ethnicity, Race, Class, Gender and Religion. An Introduction to Conceptual History," in: The Contested Nation. Ethnicity, Class, Religion and Gender in National Histories, ed. Stefan Berger and Chirs Lorenz (New York: Palgrave Macmillan, 2011), pp. 24-59.

3 Azurmendi, ETA de principio a fin; Javier Díaz Freire, "El cuerpo de Aitor: emoción y discurso en la creación de la comunidad nacional vasca," Historia Social, No. 40 (2001), pp. 79-96; Pedro José Chacón, "Introducción al estudio de la etapa barcelonesa de Sabino Arana Goiri (1883-1888)”, Letras de Deusto, Vol. 42, No. 134 (2012), pp. 155-182.

4 Santiago de Pablo and Ludger Mees, El péndulo patriótico. Historia del Partido Nacionalista Vasco (1895-2005) (Barcelona: Crítica, 2005). 
In the late 1960s, the Basque nationalist discourse became hegemonic among the anti-Franco movement in the Basque Country, and the idea of a dichotomy between a Basque-progressive-democratic people and an antiquated-fascist-dictatorial Spain was widely assumed by the Basque society. ${ }^{5}$ Both the appropriation of Spanish identity by Franco's dictatorship, ${ }^{6}$ on the one hand, and ETA's violent campaign against the dictatorship and its socialist rhetoric, on the other, were the key elements to the assumption of that national dichotomy in the Basque Country. ${ }^{7}$

It is widely accepted that what was called the Spanish Transition implied an enormous transformation of Spanish national self-identification. Especially after the June 1977 elections, the period between Franco's death and the arrival of the first socialist government (1975-1982) was transmitted by the main media, the government, and the major parties in a very specific way. The period of 1975-1982 was explained as a lineal path that, after four decades of dictatorship, had achieved the emergence of a modern and democratic Spanish nation. ${ }^{8}$ In that sense, key elements were eluded from the Spanish Transition's main narration, such as the government's authoritarian practice that guided the process and the multiple-sourced violence that accompanied that time. ${ }^{9}$ However, it was a very successful narrative.

In the aforementioned context, Herri Batasuna, stuck in the demand that the government must accept the KAS Alternative to be considered democratic, was isolated from the Spanish widely accepted narration of those same years.

5 Francisco Letamendia, Historia del nacionalismo vasco y de ETA.

6 Ismael Saz, "Las culturas de los nacionalismos franquistas," Ayer, No.71 (2008), pp. 153-174.

7 Mikel Arriaga, Y nosotros que éramos de HB: sociología de una heterodoxia abertzale (San Sebastian: Haranburu, 1997).

8 Sebastian Balfour and Alejandro Quiroga, España reinventada. Nación e identidad desde la Transición (Barcelona: Ediciones Península, 2007); Jordi Muñoz, La construcción política de la identidad española: ¿del nacionalcatolicismo al patriotismo democrático? (Madrid: Centro de Investigaciones Sociológicas, 2012).

9 Ferran Gallego, El mito de la Transición. La crisis del franquismo y los orígenes de la democracia (1973-1977) (Barcelona: Crítica, 2008) Gonzalo Wilhelmi, Romper el consenso. La izquierda radical en la Transición española (1975-1982) (Madrid: Siglo XXI de España, 2016); Sophie Baby, "Volver sobre la Inmaculada Transición. El mito de una transición pacífica en España," in: La transición española. Nuevos enfoques para un viejo debate, ed. Marie-Claude Chaput and Julio Pérez Serrano (Madrid: Biblioteca Nueva, 2015), pp. 75-92. 
Moreover, the isolation of Herri Batasuna grew ever larger because they accepted ETA's violence until what they understood as a real breakdown with Francoism was to be achieved.

Herri Batasuna was, according to itself, the heir of the wide anti-Franco movement in the Basque Country and was based on the idea of a dichotomy between a Basque-progressive-democratic people and an antiquated-fascistdictatorial Spain. Its large support in every election proved that it represented a considerable feeling among Basque society at the time. But after the approval of the 1978 Constitution, a mutual and constant misunderstanding was the rule between Herri Batasuna's self-image and Spanish public opinion, as we will explain.

The first film we will introduce precisely contextualises that breakdown between Herri Batasuna and the widely accepted public opinion. The story told in Erreporteroak (1983) shows how this trend in public opinion appeared. Though its quality is not brilliant, we think the film shows in a sincere way the mood of the time and that it has a considerable symbolic importance.

It is the story of two reporters, good friends and flatmates, during 1980 and 1981. But the political developments during that time will put a great strain on their relationship. We will highlight two ideas that are developed in the film: 1) ETA as something from the past, and 2) Herri Batasuna's position as being irrational and non-political.

Once the socialist party reached the government in 1982, the previously explained idea of a modern and democratic Spain was widely accepted. It finally arrived, with the young socialists' government. In that sense, ETA, which appeared during Francoism, was felt as the last breath of a sad past.

Thus, if Spain had obtained finally a democratic political system, the past was a pre-political period. And ETA was categorised as an irrational organisation, something from the pre-political and violent past (the dictatorship). According to Spanish public opinion, ETA was acceptable before, but not in the new political and rational Spain. In a very interesting turn of events, ETA, obsessed with the effective breakup with Francoism through the KAS Alternative, filled the vacuum of fascism left behind by Franco, according to public opinion.

Thereby, Herri Batasuna, which supported KAS Alternative, became the social symbol of the maintenance of ETA, a pre-political, irrational, and fascist phenomenon once Franco died. This process is conceptualised in Erreporteroak, where the protagonists part company after the failed Spanish military coup d'état on 23 February 1981, and a difference of opinion leads to one of them joining Herri Batasuna. "You're losing the plot!" is his former friend's answer to that decision. 
Furthermore, another idea that we must emphasise from Erreporteroak is that Basques are seen as a traditional rural community in the modern Spain, as shown through the relationship that both protagonists have with two Spanish girls that are filming a documentary about the Basque people. "For them, the Basque people... in the mountain and the sea," criticises the one linked to Herri Batasuna, referring ironically to the Basque society of the time that was in fact highly industrialised.

That rural image had been exploited by official media during Franco's time: it had presented the Basques' as noble people, ancient because of their languageBasque is the only pre-Indo-European language spoken in Western Europeand traditions. But the same stereotype had also been used in Basque nationalist imaginary: they were not Spanish, because they were there, before the Spanish came. Indeed, what is interesting for our analysis is how the ruralised and traditional image created a powerful symbolic link between the past, Franco for Spanish public opinion, and those who claimed to be the real defenders of the Basque people, Herri Batasuna, in the new modern Spain of the 1980s.

La muerte de Mikel (1984), the second film we have chosen for this chapter, is the story of Mikel, a homosexual Herri Batasuna militant. The plot emphasises the political isolation of the coalition, as it was the fact for the mid-1980s. It also highlights the importance of Spanish police's violence in the Basque Country, which in fact was one of the determining factors that made Herri Batasuna's discourse credible. But the film gives the impression that their claim of this police's violence as proof of the continuity of Francoism only nourished the violent situation.

The main idea is maintained during the movie: normal Basque people are in the middle, surrounded by two alien elements, two obstacles from the past-the Spanish police's violence and Herri Batasuna's attitude. This is the most important image of the film, constructed step by step during the sequence of Mikel's funeral. His former comrades are gathered outside the church, and Spanish police is located in front of them. Allegorically, the mass becomes a celebration of Spanish modernity, in spite of the people that, outside the church, oppose the new political system.

Overall, Mikel's problem of accepting his homosexuality, and making himself accepted, is only a metaphor of that image. His exclusion from Herri Batasuna's city council candidacy is presented as the proof that the coalition does not accept the modernisation of society and that it is clinging to the past. It is presented again as something from the past, an agent who feeds violence and, furthermore, is intolerant to people's personal decisions. 
The director of the film, Imanol Uribe, has recently admitted that he invented the plot to focus on criticising Herri Batasuna's attitude (La 2, 2013). He explained that he heard something about a person excluded from the coalition because of a drug addiction. Nevertheless, he thought that the gay issue would be better for a film, forgetting the fact that the Herri Batasuna was among those political parties that had supported the gay liberation movement since the late 1970s.

A very obvious visual link was constructed in La muerte de Mikel that highlighted the stereotyped traditional image of Herri Batasuna: Mikel kisses his boyfriend to say goodbye in his town, and the camera focuses on some old men who wear traditional clothes, behind the gay couple. Upfront, the next scene occurs in Herri Batasuna's headquarters, where Mikel is told that he is not going to be part of the candidacy. He answers angrily: "You're such a priest!" That is to say, the film emphasises the idea that Herri Batasuna is, along with the catholic clergy, an antique obstacle to the modernisation of society.

We can contextualise Uribe's position in the shift that occurred among the public opinion from the late 1970s onwards, regarding ETA's violence. His first film, El proceso de Burgos (1979) (Burgos Trial), was a documentary about ETA members that were judged in 1970 by a Spanish military court. And his message was not far from Herri Batasuna's discourse. Two years later, he released La Fuga de Segovia (1981) (Flight from Segovia), an action film based on a real escape from Segovia prison that ETA members organized in 1976. In the film, he shared the idea of ETA as something that should have disappeared after Franco. With La muerte de Mikel, Imanol Uribe reached the definitive breakdown with the political culture represented by Herri Batasuna. ${ }^{10}$

The next film we will analyse tells the story of Dolores González Yoyes. A former prominent member of ETA, Yoyes left the organisation in 1979. In 1985 she came home from exile. She did not formally accept the terms of government's reintegration policy, but she was still an important symbol both for the Spanish Government and for ETA. The Spanish media presented her return as a victory and she was ultimately assassinated shortly after she had returned to her home town. Yoyes' assassination was one of the most controversial murders committed by ETA. Yoyes' story being very well known in the Basque Country-the viewer knows how the film will end-, the interesting thing about the movie is how the characters and the main symbolic elements are presented.

10 Larreta C. Roldán, “Una apuesta suicida; ETA en el cine de Euskadi,” Ikusgaiak, No. 5 (2001), pp. 181-205. 
The film Yoyes (2000) starts with a robbery committed by ETA during Franco's epoch. The plot assumes the aforementioned idea that ETA should have become extinct after Franco's death. Yoyes is presented as an individual who in 1979 realises this historical destiny. In this case, the film does not present any difference between ETA-embodied by her former male comrades-and Herri Batasunaembodied by her own brother. We should take into account that the film was made towards the late 1990s, when the Spanish Government and the media fully adopted the idea that Herri Batasuna was part of ETA and started a series of procedures to outlaw the political coalition.

The film reconstructs an interview between Yoyes and her former comrades where, after asking them, she decided to return home without their permission. However, at home, ETA's voice is still present. His brother is a Herri Batasuna councillor in the town and criticises his sister's decision during a family meal. The idea is that there is a continuum between ETA and Herri Batasuna, through men who are rude to independent women. Another member of the family emphasises the idea of the sole commitment to violence, when he assures: "you [Herri Batasuna] run in the elections, but you don't show up at parliament, not even to defend your thing." In concordance with public opinion during the late 1990s, in Yoyes, Herri Batasuna is just a loudspeaker for ETA. They are both the same thing.

The director Helena Taberna made a similar use of the character that Uribe made in Mikel's death. She presents a feminist narrative where the protagonist fights against intolerant men. In fact, Yoyes was committed to feminist issues during her ETA leadership time. ${ }^{11}$ But eluding the interesting discussion about revolutionary membership and feminism, a discussion present in every revolutionary organization during the 1970 s, ${ }^{12}$ ETA's male leadership is just shown as an obstacle to Yoyes' personal dignity during the entire plot of the film. The protagonists are presented unambiguously and appear as flat two-dimensional characters.

In essence, the film shows Herri Batasuna-ETA to be intolerant and reinforces the idea of ETA being something from the past. In this case, they were an obstacle for women's liberation. Nevertheless, far from taking into account the feminist critic to the traditional genre and family roles, the film emphasises Yoyes' role as a mother and devoted wife, and her public political commitment is seen as an obstacle to her real happiness.

11 Elixabete Lasa et al., Yoyes. Desde su ventana (Garrasi: Alberdania, 1987).

12 Cinzia Arruzza, Las sin parte. Matrimonios y divorcios entre feminismo y marxismo (Es: Crítica \& Alternativa, 2015). 
That apart, the final sequence is well constructed, in which Yoyes' assassination is represented as a ritual tribal sacrifice. Another link between ETA and the past. The idea is that the scene, set during a day celebrating Basque traditions, is a performance. Everybody knows that the traditional representation of the village is fake: Yoyes was assassinated in 1985. People were dressed as if it was a traditional society, but they knew it was not.

Nevertheless, according to the film's sequence, ETA feels that Yoyes is tainting the traditional celebration and arrives to the decision she must be sacrificed. In that long sequence, traditional musical instruments are heard for the first time in the film, louder and louder. And Yoyes' killer appears to be the priest who is committed to do a human sacrifice to ensure his tribe's ancestral life.

Returning to our argumentation about national stereotypes, Yoyes film presents Basque nationalists as the defenders of a lost paradise, a tribal antiquity that in the 1980s can only be represented as a celebration day. Once again, Herri Batasuna appears to be rural and traditional. We must notice that a rural and traditional image of the Basque Country was also recreated by the conservative Euzko Alderdi Jeltzalea (Basque Nationalist Party) that led the autonomous government during the 1980s and 1990s. Even if we acknowledge that the traditional imaginary was at some point present in Herri Batasuna's image-as in every nationalist movement-, it cannot be escaped that precisely thanks to Yoyes feminist issues appeared for the first time in ETA leadership's publications, and her own sister was deeply involved in the creation of a feminist organisation linked to ETA in 1978: KAS-Emakumeak (KAS-Women).

The last film we will analyse is a unique exception in the Basque filmography from the 1980s, because it does not reproduce the usual stereotype about Herri Batasuna. Ke arteko egunak (1989) was directed by Antton Ezeiza. Previously linked to the Communist Party of Spain (PCE) and one of the protagonists of the so-called Spanish New Cinema during the 1960s, Ezeiza became sympathetic with ETA during the early1970s. Exiled in 1973, after his return in 1977, he was involved in the creation of a Basque national cinema. ${ }^{13}$

Ke arteko egunak was the first film in Basque language that was accepted in the San Sebastian Film Festival's Official Selection. The plot is based on Pedro's return from Mexico to the Basque Country in the 1980s. Nevertheless, far from reproducing Herri Batasuna's stereotype as other films from the 1980s did, such as Golfo de Vizcaya (Bay of Biscay, Javier Rebollo, 1985) or Ander eta Yul (Ander

13 Josu Martinez, “Ikuska saila: ostarte bat laino itsasoan,” Jakin, No. 200 (2014), pp. 95-113. 
and Yul, Ana Diez, 1988), it seems that the director's aim is to make explicit the inevitable existence of the coalition in the modern Basque society.

It is an exception among the series of films that were produced, thanks to Basque autonomous government subsidies during the 1980s, in the so-called Basque cinema's growth. And it is also an exception compared to the films released during the 1990s and 2000s, when ETA members were usually represented as purely fanatic terrorists: Días contados (The Days Are Numbered, Imanol Uribe, 1994), El viaje de Arian (Arian's Trip, Eduard Bosch, 2000), Todos estamos invitados (We Are all Invited, Manuel Gutierrez Aragon, 2008), and so on. Let us explain the idea developed in Ke arteko egunak.

As most of the films that deal with Basque politics, Ke arteko egunak includes a reference to Francoism. Linked to the idea that armed organisations should have disappeared along with Franco, both the films (La muerte de Mikel and Yoyes) were obliged to represent, in a way, the popular acceptance of ETA during that epoch, and oppose that to the post-Franco modern Spain.

But in this case, the reference to Francoism is not about ETA. It is about the protagonist's father, who appears to be a prisoner arrested by the Civil Guard during the old times. The symbolical link is made with the protagonist's daughter, who is in prison for being a member of ETA. Thereby, the past-present connection is not symbolised by ETA. On the contrary, it is symbolised by the imprisonment of Basque people. That is to say, the film assumes the continuity of the aforementioned dichotomy between a Basque-progressive-democratic people and an antiquated-fascist-dictatorial Spain.

However, far from simply reproducing that dichotomy, the interest of the film rests on its conflictive approach to the idea through the protagonist, who is an alcoholic unable to maintain social relationships and is a newcomer to the Basque Country in the 1980s. The main theme is that there is a political problem in the Basque Country hard to solve, whether it suits us or not.

It is Pedro's former partner who makes Pedro and the spectator aware of the existence of a political culture linked to her daughter in prison (Herri Batasua). It is not clear if she is of the same opinion or not, but she acknowledges this possibility. Later, by chance, Pedro meets a couple who are Herri Batasuna sympathisers and makes them the centre of his new network of friends. Nevertheless, while he is distracted by his addiction to alcohol, politics is changing the world in which he resides. We must also highlight the fact that the film takes place in an entirely urban environment where, contrary to the ruralised stereotype, in this case, Herri Batasuna is totally integrated in modern society. 
The idea of Herri Batasuna as an obstacle to the end of ETA is also present. It is stated that "they do not let" Pedro's daughter reintegrate, following the government's policy regarding ETA prisoners since 1984. But one of the main characters, Kepa, pledges that "no one can stop this train," because politics is bigger than politicians. So, the film runs away from the idea of attributing Herri Batasuna a certain task. What is more, at the end of the film, Kepa joins Herri Batasuna, just as they are organizing Pedro's daughter's welcome home event, after her final release from prison. It is also important that Kepa's militancy starts just when he breaks up with his girlfriend. There is a key moment in the film when Pedro asks Kepa: "So, you are interested in politics?" and Kepa answers: "I can't escape politics."

In the final sequence, the welcome home event, there is a parallel to that of Mikel's funeral. We see a crowd in front of the police. A crowd, a gathering, in which Kepa becomes another anonymous face among Herri Batasuna sympathisers, whereas Pedro marginalises himself in the cocoon of his alcoholism. Overall, the film highlights the isolated position of Herri Batasuna in society too, but in this case, not as an obstacle to normality as in other films. Quite the opposite, Herri Batasuna is understood as the proof of an exceptional political situation.

After having analysed those four films, it is time for conclusions. First of all, we must underline that Herri Batasuna's stereotype as something from the past, traditional and irrational, was an image built in a confident relationship with the Spanish political developments during the late 1970s and early 1980s. Herri Batasuna had a discourse based on the anti-Francoist opposition from the late 1970s, but once the Constitution was ruling, the very same discourse was seen as an obstacle to the established democracy. That is why Herri Batasuna was stereotyped as something from the past, the B side of the modern Spain. If Spain had become a democratic, rational and modern democracy, Herri Batasuna, who opposed the Constitutional monarchy, was felt as fascist, traditional and irrational by Spanish public opinion. That is the process that appears in Erreporteroak and it represents the breakdown between a part of the Basque society and the main Spanish national narration.

In that sense, for those who shared the idea of an emerging modern Spain, Herri Batasuna was conceptualised as its negative pole. Precisely, the opposition of Herri Batasuna and ETA's violent campaign functioned for the Spanish identity as proof of the new modern Spain. On the contrary, Franco's heritage, such as the Monarchy, the Army, the Civil Guard and the Spanish indivisibility written in stone in the 1978 Constitution, was for Herri Batasuna the proof that they continued fighting against a conservative-dictatorial Spain, and that they represented the progressive-democratic Basque people. Then, we should understand both 
positions' own identification and categorisation of the other, as a reflection of the symbolic dialogue that happens upon every national identification.

Second, we must highlight that ETA's armed campaign made Herri Batasuna unable to challenge the symbolic bond between their political positions and the traditional-irrational stereotype. The bombs and murders were theorised by ETA as the unassimilable element for the bourgeoisie and the necessary element for a revolutionary position. But, in fact, it functioned as an element that created mutual misunderstanding between Herri Batasuna and the Spanish public opinion.

Third, in some films, that stereotype was used as an important cinematic element. But it created inconsistent plots where the stereotyped image was overwhelming and shadowed interesting issues such as gay and women's liberation, which were supposed to be the key elements in those movies.

After the end of ETA's violent campaign in 2011, and the emergence of political movements in Spain that challenge the official narration about the Spanish Transition, we hope that Basque cinema will be able to escape insurmountable mutual national stereotyping.

\section{Bibliography}

Arriaga, Mikel. Y nosotros que éramos de HB: sociología de una heterodoxia abertzale. San Sebastian: Haranburu, 1997.

Arruzza, Cinzia. Las sin parte. Matrimonios y divorcios entre feminismo y marxismo. Es: Crítica \& Alternativa, 2015.

Azurmendi, José Félix, ETA de principio a fin. Crónica documentada de un relato. Donostia: Ttartalo, 2014.

Azurmendi, Joxe. Volksgeist, Herri Gogoa. Ilustraziotik nazismora. Es: Elkar, 2007.

Baby, Sophie. "Volver sobre la Inmaculada Transición. El mito de una transición pacífica en España." In: La transición española. Nuevos enfoques para un viejo debate, ed. Marie-Claude Chaput and Julio Pérez Serrano. Madrid: Biblioteca Nueva, 2015, pp. 75-92.

Balfour, Sebastian and Quiroga, Alejandro. España reinventada. Nación e identidad desde la Transición. Barcelona: Ediciones Península, 2007.

Chacón, Pedro José. "Introducción al estudio de la etapa barcelonesa de Sabino Arana Goiri (1883-1888)." Letras de Deusto, Vol. 42, No. 134, 2012, pp. 155-182.

De Pablo, Santiago and Mees, Ludger. El péndulo patriótico. Historia del Partido Nacionalista Vasco (1895-2005). Barcelona: Crítica, 2005.

Díaz Freire, Javier. "El cuerpo de Aitor: emoción y discurso en la creación de la comunidad nacional vasca." Historia Social, No. 40, 2001, pp. 79-96. 
Fernández Soldevilla, Gaizka. Héroes, heterodoxos, traidores: historia de Euskadiko Ezkerra (1974-1994). Madrid: Tecnos, 2013.

Gallego, Ferran. El mito de la Transición. La crisis del franquismo y los orígenes de la democracia (1973-1977). Barcelona: Crítica, 2008.

García, Juan. "Nación, identidad y paradoja. Una perspectiva relacional para el estudio del nacionalismo." Reis: Revista española de investigaciones sociológicas, No. 67, 1994, pp. 165-186.

Garmendia, José María. Historia de ETA. Donostia: Haranburu, 1996.

Lasa, Elixabete; González Katarain, Glori; González Katarain, Ana; Garmendia Lasa, Juli; Dorronsoro, Juango. Yoyes. Desde su ventana. Garrasi: Alberdania, 1987.

Letamendia, Francisco, Historia del nacionalismo vasco y de ETA. San Sebastián: $\mathrm{R} \& \mathrm{~B}, 1994$.

Letamendia, Francisco. Juego de espejos. Conflictos nacionales centro-periferia. Donostia: Trotta, 1997.

López Romo, Raúl. Del gueto a la calle. El movimiento gay y lesbiano en el País Vasco y Navarra, 1975-1983. San Sebastian: Tercera Prensa, 2008.

Lorenz, Chris. "Representations of Identity: Ethnicity, Race, Class, Gender and Religion. An Introduction to Conceptual History." In: The Contested Nation. Ethnicity, Class, Religion and Gender in National Histories, ed. Stefan Berger and Chirs Lorenz. New York: Palgrave Macmillan, 2011, pp. 24-59.

Martinez, Josu. "Ikuska saila: ostarte bat laino itsasoan." Jakin, No. 200, 2014, pp. 95-113.

Muñoz, Jordi. La construcción política de la identidad española: ¿del nacionalcatolicismo al patriotismo democrático? Madrid: Centro de Investigaciones Sociológicas, 2012.

Roldán, Larreta, C. “Una apuesta suicida; ETA en el cine de Euskadi.” Ikusgaiak, No. 5, 2001, pp. 181-205.

Saz, Ismael. "Las culturas de los nacionalismos franquistas." Ayer, No.71, 2008, pp. 153-174.

Saz, Ismael. "Regeneracionismos y nuevos nacionalismos. El caso español en una perspectiva europea." In: Estudios sobre nacionalismo y nación en la España contemporánea, ed. Ismael Saz Campos and Ferran Archilés. Zaragoza: Prensas Universitarias de Zaragoza, 2011, pp. 55-78.

Wilhelmi, Gonzalo. Romper el consenso. La izquierda radical en la Transición española (1975-1982). Madrid: Siglo XXI de España, 2016. 

Iratxe Fresneda

University of the Basque Country UPV/EHU

Audiovisual Communication Department

Amaia Nerekan

University of the Basque Country UPV/EHU

\title{
5. New content and aesthetics in small cinemas: The case of the Basque-language films 80 egunean and Loreak
}

\begin{abstract}
In 2015, at the 63rd San Sebastian International Film Festival, cultural policy makers from 15 countries and regions where non-hegemonic languages are spoken issued the manifesto, Glocal Cinema: Big Stories, Small Countries. This manifesto seeks to promote and showcase the value of the work of professionals from these Small Cinemas. Together with this, 2005 can be considered a turning point in Basque-language cinematography, which is included in the Small Cinemas group. This year saw a substantial growth in the production of Basque films that turn from content typecast under the Basque Conflict, demonstrating the emergence of new aesthetics, content, and formats of audiovisual production. Moreover, the films directed by Jon Goenaga and Jose Mari Garaño attained international recognition, winning many international awards, and one of these films was selected to compete at the Oscar Awards. This chapter explores how local cinema become Global Cinema, analyzing the films 80 egunean and Loreak and examining their content and the aesthetics tied to their successful production, distribution, and exhibition.
\end{abstract}

Keywords: Basque cinema, Glocal cinema, small cinema, cinema in the Basque language, 80 egunean, Loreak

\section{Introduction}

Multilingualism is one of the main characteristics of the cultural diversity of the European Union (EU). The key aims of the EU specified in the Treaty on European Union (TEU) include that of respecting "its rich cultural and linguistic diversity" and ensuring that "Europe's cultural heritage is safeguarded and enhanced" (article 3, TEU). According to the European Commission, the EU has 500 million citizens 
and 24 official languages, ${ }^{1}$ a figure that is lower than that of member states, which is 28 , since several share the same language. But alongside the official languages, there are over 60 regional or autochthonous minority languages in the EU, with a total of some 40 million speakers, almost $10 \%$ of EU citizens. These minority languages include Euskera, the Basque language.

Conscious of this cultural and linguistic diversity, many initiatives have been set underway in recent years. At the 63rd San Sebastian International Film Festival (Zinemaldia), a total of 15 European regions, including the Basque Country, signed the manifesto "Glocal cinema: big stories, small countries," to encourage cinema in non-hegemonic languages. As the manifesto states, despite the increasing market share of European films and the growing weight of internal production in the European market, "if we take a look at the most seen films in Europe in 2014, 18 of the top 20 are in English, French, German or Spanish.” This makes it patently clear that European filmographies produced in non-hegemonic languages require special attention and public support.

This chapter explores how the local cinema can become Global Cinema by analyzing the films 80 egunean and Loreak and by examining their content and the aesthetic tied to the independent production and coproduction as keys of success.

For that purpose, this chapter first provides a survey of fiction feature films made in Euskera up to the end of 2015, making use of the database of rated films of the Ministry of Culture and taking account of the different publications on the question and the abovementioned manifesto "Glocal cinema: big stories, small countries." Finally, it focuses on two Basque-language feature films that have achieved international success in recent years: 80 egunean ( 80 Days) and Loreak (Flowers), directed by Jose Mari Goenaga and Jon Garaño. These directors have a long and successful career and are one of the main referents in the New Basque Cinema.

\section{Manifesto: Glocal cinema: big stories, small countries ${ }^{2}$}

The manifesto "Glocal cinema: big stories, small countries" was presented on 21 September 2015 during the 63rd San Sebastian International Film Festival. This was signed by 15 European regions, ${ }^{3}$ including the Basque Country. The main aim

1 The 24 official working languages are Bulgarian, Croatian, Czech, Danish, Dutch, English, Estonian, Finnish, French, German, Greek, Hungarian, Irish, Italian, Latvian, Lithuanian, Maltese, Polish, Portuguese, Romanian, Slovak, Slovene, Spanish, and Swedish.

2 Manifiesto available online at the following link: http://www.glocalcinema.com/pages/ manifesto.

3 Wales, Sweden, Slovenia, Finland, Poland, Norway, Latvia, Ireland, Iceland, Hungary, Italy, Fruili, Estonia, Denmark, and the Basque Country. 
of this initiative is to encourage cinema in non-hegemonic European languages, by which is meant European cinema not filmed in English, French, German, Spanish, or Italian.

The manifesto, which extols the value of Europe's cultural and linguistic diversity, aims to "reinforce the value of another cultural map of Europe, with the distribution and exhibition of films in languages other than the louder European languages" and calls for "public support for this important issue." There are many filmmakers who decide to make their films in minority languages, although this entails positioning themselves in a very small market and creates difficulties for funding, distributing, and screening those films. Institutional support becomes especially important in this case. The manifesto aims to raise awareness of the importance of small cinemas, due to "the need of every community to tell its own stories in its own languages."

The document contains a four-point agenda, with the aim of strengthening the activities of the cinematographic industry in small- and medium-sized languages: ${ }^{4}$

1. To create a formal workgroup.

2. To support meetings and cooperation among filmmakers.

3. To increase knowledge of the linguistic diversity of European cinema.

4. To increase the visibility of small cinemas.

The signatories agree to meet periodically in the framework of the European film festivals. Following the first meeting, the workgroup met again at the 66th edition of the Berlinale and will do so again at the next edition to set the roadmap for 2018. The Glocal Cinemas Network also participated in the European Film Forum held in Brussels in December 2016. ${ }^{5}$

4 A novel feature of the last edition of the San Sebastian Festival with respect to the industry was the Focus on Glocal Cinemas, held during the V Europe-Latin America Co-production Forum. This was a meeting of professionals, set up in collaboration with the Glocal Cinemas Network, and is the starting point for creating a new activity in the industry in 2017. This will consist in screening European films in non-hegemonic languages in post-production to an audience of producers, distributers, sales agents, and programmers who can contribute to their completion and international circulation. This new activity will be called Glocal in Progress.

5 Information from an online interview with Jara Ayucar, coordinator of the Glocal Cinema project, during the 64th San Sebastian Festival. 


\section{Cinema made in Basque}

\section{Basque cinema or cinema made in Basque? To be or not to be}

Although this chapter focuses on fiction feature films in Euskera (Basque), the first film made in that language (partly in Spanish) was not fiction, but the documentary Ama Lur (Tierra Madre) (Néstor Basterretxea and Fernando Larruquert). ${ }^{6}$ It was premiered in 1968 during the debate over what should be considered Basque cinema. ${ }^{7}$ For some the language employed is, from the outset, the key factor in defense of a Basque cinematography. One author who defended this position was Antton Ezeiza, a filmmaker from San Sebastian recently returned from exile, who "argue[d] for a Basque national filmography whose first condition is Euskera” (Roldán, 1996: 166). An initial step in developing this Basque-language cinematography was the production of the series Ikuska, produced between 1978 and 1984 by the producer Bertan Filmeak. This series was coordinated by Ezeiza himself and consisted of 20 shorts directed by different Basque directors.

A decade after the premiere of Ama Lur, the first Basque-language fiction feature film, Balantzatxoa, reached the cinemas. From then until 2015 a total of 38 fiction films were produced in Euskera. The production and development of Basque-language cinematography is uneven, with periods of scant production and others that are more fruitful, directly related to the cultural policies in effect in each period.

6 It is worth highlighting the recent discovery by Josu Martínez, a researcher at the University of the Basque Country (UPV/EHU), who found a mute copy of a documentary feature film titled Gure sor lekua (Our Birthplace), which can be considered the first film shot in Euskera in the late 1950s and was believed lost. It was directed by General André Madré, who was born in Hazparne. According to Josu Martínez, this is the first film in Euskera, although it must be said that in researching his doctoral thesis, later published as a book (Martínez, 2015), he was unable to find the film's soundtrack, which would have provided irrefutable proof that this is the first film shot in Euskera.

7 There are many publications defending various positions on the debate over the existence of a Basque Cinema and what its characteristics should be, a debate that was fervent in the 1970s and, above all, after the end of Francoism. There are more general publications, like those of Zunzunegui (1985), Unsain (1985),De Pablo (1996), and others, that focus more on the importance of Euskera in that definition of Basque Cinema, such as the articles by Roldán Larreta (1996 and 1997). It is also worth highlighting the work of Torrado (2004), who traces the evolution of the concept of Basque cinema through the bibliography, and one of the most recent articles published on the subject, Macías (2011). 
Without going into whether or not the language defines a film as "Basque," it is unquestionable that the development of cinema in Euskera has been (and currently continues to be) dependent on the mechanisms of protecting and funding the language. ${ }^{8}$ In Josu Barambones's analysis of Basque-language cinema, he observes that during the 1980s cinema made in Euskera "experienced what can be called 'the golden age of Basque cinema'" (Barambones, 2011: 6). He attributes this boom in production to the grants policy established by the Basque government at that time, together with the grants awarded by the Spanish state, from the Ministry directed by Pilar Miró:

Within this context of institutional support, in 1982 the Department of Culture of the Basque government set up a project aimed at producing, with technical personnel from the Basque Country, six films based on literary works by Basque authors who write in Euskera. From this initial project, three medium-length films emerged during 1985 lasting approximately 55 minutes: Zergatik Panpox (Why Cutie) (1985), directed by Xabier Elorriaga and based on the novel by the writer Arantxa Urretabizkaia; Ehun metro (One Hundred Meters) (1985), by Alfonso Ungria, based on the novel by Ramon Saizarbitoria; and Hamaseigarrenean aidanez (It Happened on the Sixteenth) (1985) directed by Angel Lertxundi and based on his own novel (Barambones, 2011: 7).

These three films were joined by another two films shot in the late 1980s: Oraingoz izen gabe (Still Nameless) (1986) by José Julián Bakedano with a screenplay by Bernardo Atxaga and Kareletik (Overboard) (1987) directed by Angel Lertxundi; these were followed by Ander eta Yul (Ander and Yul, Ana Díez, 1988) and Ke arteko egunak (Days of Smoke, 1989, Antton Ezeiza).

The 1980s, an exciting decade in terms of the number of productions, were followed by years when the production of films in Euskera virtually ceased. During the 1990s only three feature films were released, compared to the nine films shot in the previous decade: Offeko maitasuna (Amor en Off) (Koldo Izagirre, 1992), Urte ilunak (The Dark Years) (Arantxa Lazkano, 1993), and Maitè, a Basque-Cuban coproduction directed by Carlos Zabala and Eneko Olasagasti, where the Basque characters speak Euskera among themselves and Spanish with the Cubans on the island. Following the release of Maitè in 1994, no film was shot for over a decade due in large part to the "Basque government's disastrous policy of subsidies" (Barambones, 2011: 7). During a large part of the 1990s, Euskal Media (Basque Government's public society) ignored incomprehensibly the most interesting

8 Miren Manias Muñoz has researched the production and funding of cinema in Euskera. In her doctoral thesis "Euskarazko zinemaren produkzioa eta finantziazioa (2005-2012): hamaika fikziozko film luzeren azterketa ekonomikoa," she makes an economic analysis of 11 feature films produced in Euskera. 
and box office projects of the Basque filmmakers, forcing many directors to disassociate themselves from Basque Country. There are cases of successes such as Mutant Action (1993) by Alex de la Iglesia, Squirrels (1993) by Julio Medem, Stories of the Kronen (1995) by Montxo Armendáriz, The Day of the Beast (1995) by Alex de la Iglesia, and Tierra (1996) by Julio Medem.

\section{Aupa Etxebeste! Go, cinema in Basque, go!}

The release of the film Aupa Etxebeste! (Go Etxebeste!), the first work by Telmo Esnal and Asier Altuna in 2005, was a turning point in the production of feature films in Euskera for several reasons. After more than 10 years without the release of any films shot entirely in Euskera, the commercial success it achieved, with 71,972 spectators and box office takings of $€ 341,462.88$, encouraged many other creators to produce in Euskera, since "films like Aupa Etxebeste! demonstrate that if the public is offered a quality product and it is suitably promoted, the spectators will respond" (Barambones, 2011: 8). Screened in cinemas in the original version with subtitles in Spanish, Aupa Etxebeste! was selected for several international festivals and won prizes.

This film's genre was also completely novel in Basque-language cinema. While the films from the 1980s and 1990s had mainly been dramas, Esnal and Altuna chose to produce a comedy, ${ }^{9}$ with a fresher and more cheerful subject, removed from the socio-political problems that had been so prevalent in Basque cinema in previous decades, in both Euskera and Spanish. This was cinema whose subject matter was less politicized than that of earlier years:

[I]t is true that at first nationalist ideology loomed over the field in a truly obsessive way, and it was really difficult to find a film that was not focused on the convulsive reality of the country or that did not return to the past to delve into its historical origins. But this is something that was to be lost as time passed and the political situation was normalized (Roldán Larreta, 1999: 9).

From 2005 onward, at least one film in Euskera was made each year (except in 2008), thanks to the agreement signed by the associations of Basque producers (Association of Independent Audiovisual Producers of the Basque Country

9 Previously only one comedy had been produced, Maitè, a Basque-Cuban coproduction by Carlos Zabala and Eneko Olasagasti, in 1994. Following the release of Aupa Etxebeste! in 2005, the tendency changed and other comedies were released in Euskera: Kutsidazu bidea, Ixabel (Follow The Way, Ixabel) (2006), Eutsi! (Hold On!) (2007), Sukalde kontuak (Cooking Secrets) (2009), Zigortzaileak (The Punishers) (2010), Urteberri on, Amona! (Happy New Year, Granma!) (2011), and Bypass (2012). 
[IBAIA] and Basque Producers Association [EPE-APV]), the Basque government and the Basque public broadcasting corporation (EITB). This agreement established a production quota of one feature film in Euskera per year. This was widened in the agreement of 2008, which established that at least two films should be made in Euskera in subsequent years. In her research on the funding of Basque-language cinema, Miren Manías highlights the contribution of EITB, which she considers "has been a fundamental source of funding for the development of cinematography in recent years" (Manías, 2015: 92). The increase in the production of Basque-language cinema was notable in this final stage, and as many as five films in Euskera were released in 2011. Some authors cautiously speak of a "recovery of cinema in Euskera" and note that public investments in the creative, technical, and economic fields are of great help in laying solid foundations that will give long-term continuity to Basque-language cinema. However, they warn about the fragility of that recovery and that there is a danger of a drop in institutional support due to the cutbacks derived from the economic crisis (Manías, 2013).

Together with production, this last period has seen a notable increase in the technical and artistic quality of the films shot in Euskera. Young directors are starting to make a name for themselves, such as Asier Altuna (Aupa Etxebeste! 2005, Amama [Amama - When a Tree Falls] 2016), Telmo Esnal (Aupa Etxebeste! 2005, Urteberri on, Amona! 2011), and Jon Garaño and Jose Mari Goenega (80 egunean 2010, Loreak 2014). A new crop of filmmakers who are opting, in spite of the difficulties, to make high-quality cinema in Euskera is receiving considerable recognition at festivals - even internationally in some cases - although without repeating the box office figures achieved in 2015 by Aupa Etxebeste! This is the case of 80 egunean and Loreak.

\section{Case study of 80 egunean ( 80 Days): The film's authors (directors and screenwriters)}

Jon Garaño (San Sebastian, 1974) and José Mari Goenaga (Ordizia, 1976) studied together in San Sebastian at the Sarobe Film School. In 2001, after completing their studies, they formed the Moriarti production company together with another four colleagues: Xabier Berzosa, Aitor Arregi, Asier Acha, and Jorge Gil Munarriz. Together and separately they have directed successful works, including the prizewinning shorts Tercero B, Sintonía, and Lagun Mina, which between them have won over 150 prizes. The animated feature Supertramps (nominated for the Goya award for Best Animated Film in 2005) and the feature-length documentary Lucio (premiered at the San Sebastian International Film Festival and nominated for 
the Goya award for Best Documentary Film in 2007) were key works when it came to securing a place for the work of young Basque filmmakers in the Basque and European audiovisual market. 80 egunean and Loreak are thus the result of a solid trajectory.

\section{0 egunean}

The plot: Axun is a 70-year-old woman who reencounters her great friend from adolescence, Maite, a music teacher who lives outside the conventions of the women of her generation.

Filmed entirely in Basque, this is the only representation to date in Basque cinema of "older" women belonging to the LGBTI collective. It deals with the friendship that has existed between the protagonists since their childhood, their sexual attraction in the third age and the consequences of this on their family environment.

\section{"Risky" cinema}

There is a common and inherent feature in making any film: the economic risk entailed in investing time and money in a highly uncertain market. In the case of 80 egunean, the linguistic option - choosing a minority language as a vehicle generates another series of difficulties. But in addition to the risk involved in producing a film in a non-hegemonic language, 80 egunean adds other "risks" in the choice of subject and the profile of its characters: The protagonists are elderly, as well as being women who love other women with whom they have sexual relations (this is not a pornographic film). As Andrea Francisco observes in an interesting article on sexual diversity and educational inclusion "since the beginning of cinema and television, lesbian and bisexual characters have been almost non-existent and when a love story between two women was presented, it always ended in tragedy, depression, madness or perversion" (Amat Francisco and Moliner Miravet, 2011: 155).

\section{Subject versus form}

Some of the main issues dealt with in the story of 80 egunean emerge from the universal duality, life and death, to frame the story and differentiate between men and women, the countryside and cosmopolitanism, but above all to highlight the friction between the private and public spaces. The characters of Axun and Maite are constructed in that context. Axun is a housewife who feels desire for another woman, but she is married, attached to tradition and religion. Maite is a political 
lesbian, a music teacher, single, empowered, and liberated. Both are portrayed by means of close-ups that underline their psychology. There are frequent shots in which both are in the same frame, stressing their emotional proximity. The camera also observes the characters from afar, in exterior space and into the public sphere. The form speaks of intimacy, the importance of liberation in the private space to achieve freedom in the public space.

This melodrama, a film about everyday life, generates a two-way flow between collective conflict and the individual. On the one hand, we have the conflict between the hegemonic sexuality versus out-of-system sexualities, and on the other hand, we have the individual fighting with socio-political issues in Basque Country.

At the end of 80 egunean, in the last sequence, Mikel's funeral is portrayed as a kind of liberation from the Basque Conflict theme connecting with La muerte de Mikel (1984) by Imanol Uribe. Both films are tied with the link of LGBT characters in intimidating communities.

In La muerte the Mikel, we see a man, a left nationalist pharmacist, who is in love with a drag woman in a heteronormative society, fighting for his sexual identity.

In 80 egunean, two women are in love in, also, a heteronormative society fighting for their love.

Thirty years later 80 egunean works as a kind of relief from the past. Metaphorically it tells us that a new way of making cinema, with new themes, is just arriving when they buried Mikel in 80 egunean (they are also burying the past that La muerte de Mikel represents), also a new society is arriving hopefully.

\section{Case study of Loreak (Flowers): Glocal cinema destined for the red carpet}

Loreak is the second fiction feature film directed by the duo Garaño-Goenaga and, like 80 egunean, female characters are the protagonists. Loreak tells the story of three women whose lives are emotionally affected by the appearance of mysterious bouquets of flowers. It is a simple, moving film, completely shot in Euskera. Its unprecedented success makes it a landmark in Basque-language cinema.

Since it was premiered at Zinemaldia in 2014, the trajectory of Loreak has been intense: forty festivals, nominated as best film for the Goya awards and screened at a dozen festivals in the United States, amongst many other nominations, prizes and events. The result in terms of prizes has been lower than one might expect from the film's reception. Indeed, the film has been widely praised by the critics, who have described it as: "A true jewel of sensitivity, intelligence and beauty" (Fotogramas), "magnificent, simplicity made 
into art" (El Mundo), "prodigious narrative" (Gara), "notable delicacy, sensitivity and poetry" (El País), a "superb” film (Deia) or "cinema in capital letters" (El Diario Vasco) (Rincón, 2016: 2).

With nearly twice as many spectators as the previous film $(47,099)$ and nearly double the box office takings (€254,400.83), Loreak marks a turning point in Basque-language cinema for several reasons: It was the first film shot entirely in Euskera to be selected for the Official Section of the San Sebastian International Film Festival ${ }^{10}$ and it was shortlisted by the Academy of Cinematographic Arts and Sciences to represent Spain for the Oscar for Best Foreign Language Film, although it was not finally selected. This circumstance was described as an "historic event" by the Basque government.

This news was greeted with surprise and great enthusiasm by everyone who formed part of the project. Selection for the prizes of the Hollywood Cinema Academy was described as an "historical event" by Cristina Uriarte, Counselor for Culture of the Basque government, at the briefing by the autonomous government's spokesperson, Josu Erkoreka, which she interrupted to make the news known (Rincón, 2016: 2).

The decision by the directors to film in Euskera occurred as something "natural," as they themselves have stated more than once. It was also conditioned by the cultural and subsidy policies of the public institutions, which carry out positive discrimination in favor of productions in Euskera. ${ }^{11}$

In the Basque Country, above all EITB, they carry out positive discrimination in favor of films in Euskera, and support them with greater subsidies, so it is true that perhaps one loses on one side, or it is more difficult to obtain funding through some channels, but one opens up others. Moreover, in this case, we were lucky in that the Ministry of Culture got involved, as did Spanish Television... it is a film that a priori, in spite of being in Euskera, has been well supported in terms of funding. Later on, the effect this might have on box office takings, we're aware that this could somewhat restrict the takings in Spanish territory. But it is also true, for example, that if there is a vocation to reach other countries and for the film to be distributed elsewhere, then the language does not have such an effect. You go to international festivals and it doesn't matter if the film is in Czech or in Romanian, in Euskera or in Spanish, they are going to treat you the same.

10 Loreak opened up a path that was continued in the next edition of Zinemaldi, at which another film in Euskera also took part in the Official Section: Amama (Asier Altuna, 2015).

11 Source: José Mari Goenaga and Jon Garaño interviewed by Eloy Cabacas for Lgecine, available online at the following link: http://lgecine.org/2014/10/entrevista-jose-mariagoenaga-y-jon-garano-directores-de-loreak/. 
Furthermore, if it is a film in a minority language, that can even be a point in its favor (Cabacas, 2014, my translation).

Besides the language, another characteristic that defines Loreak is its simplicity with respect to both its content and form. Loreak is an intimate drama, but at the same time an "emotional thriller." A mysterious bouquet of flowers serves as an excuse to unite the story of the three women protagonists. On one side, there is Ane (Nagore Aranburu), a young woman with a sad appearance, whose life changes unexpectedly when she begins to receive a bouquet of flowers each week from an unknown sender. The flowers contribute illusion to her gray and monotonous married life. On the other side, there are Tere (Itziar Aizpuru) and Lourdes (Itziar Ituño), whose lives are also affected by some flowers. Every week an unknown person places a bouquet at the site where someone of great importance to them died in a traffic accident (Tere's son and Lourdes's husband). In this case the meaning of flowers is very different; these flowers are for remembering, for not forgetting. This is the underlying theme in Loreak. It speaks of memory, of the conflict between remembering and forgetting. One of the characters chooses to preserve memories, while another believes that forgetting is the best way to heal wounds. The position of the film's characters, with its clear political background, can be extrapolated to what is happening today in the Spanish state. Far from remaining at the local level, Loreak is a film that deals with a global, universal issue, that of (historical) memory.

Simplicity is a part of Goenaga and Garaño's formal wager. With Loreak, they propose a cinematographic aesthetic where less is more, restrained like the film's characters, carrying out a game of mirrors among the protagonists and through the framing. The composition of the majority of the shots used to portray the characters is symmetrical. Empty rooms, dim lights, rain, calm, impenetrability, secrecy, solitude. The female characters appear isolated, incommunicado, and encapsulated. Notable in this respect is the choice of locations, since two of the female characters work in cabins, in capsules, in small glass cages. They are characters who look inward, who seek within themselves and have problems communicating with the exterior. Sometimes it is the framing itself that isolates or oppresses the character.

Films like Loreak make it clear that small cinemas can go a long way, even reaching the edge of the red carpet, and that in spite of the difficulties involved in choosing to film in a minority language, they can aspire to a successful international trajectory. 


\section{Conclusions: Toward a thematic and aesthetic evolution}

\section{Thematic evolution}

80 egunean contributes to creating a positive image that fights against the invisibility of lesbians in film, a novel undertaking that is linked to making visible and normalizing the image of the so-called "third age," giving the characters desires and concerns as active beings.

Loreak addresses the need to remember in both the personal and collective fields, and makes a gesture toward the debate on historical memory in the Spanish state.

Women are the protagonists in both films, which deal with the characters' place and role in the public and private spheres. The issues addressed have political and social importance (lesbianism, elderly people as active subjects, etc.), but at the same time they distance themselves from the issue of the Basque conflict or terrorism.

\section{Evolution of production processes}

One of the most important features in the production processes of the films analyzed is the important presence of Basque production companies (Irusoin, Moriarti, and Txintxua) which, besides being relatively new, are based in the Basque Autonomous Community.

Irusoin is an independent production and post-production company located in Bilbao and San Sebastian founded in 1982. Loreak (Flowers) has managed to become the first entirely Basque-spoken film to compete in the San Sebastian International Film Festival and to represent Spain in the Oscar Academy Awards 2016. Their previous film For 80 days ( 80 egunean) has competed in more than 130 international festivals, and Handia directed by Aitor Arregi and Jon Garaño won The Special jury Prize 2017 in San Sebastian Film Festival.

Moriarti is an independent film Production company founded in 2001 by Jon Garaño, Jose Mari Goenaga, and Aitor Arregi among others. They produced and coproduced films and documentaries such as Handia (2017), Loreak (2015), Lucio (2017) or 80 egunean (2010) together with Irusoin.

Txintxua Films S.L. is a film production company created in 2008 by Director and Screenwriter Asier Altuna and Producer Marian Fernandez Pascal. The company is based in Trintxerpe-Pasaia, near San Sebastian, and it produced films such as Amama by Asier Altuna (scored in 2015 in San Sebastian competition), Ghost Ship by Koldo Almandoz (scored in 2016 in Zabaltegi-Tabakalera San Sebastian Film Festival), and Dantza directed by Telmo Esnal (awarded with Glocal In Progress award 2017 in San Sebastian International Film Festival among others). 
On the other hand, we would suggest that some of the Basque government's measures of positive discrimination in favor of films shot in Basque have contributed to the production of both films, together with EITB's coproduction.

\section{Aesthetic evolution}

As a result of the evolution in both the subjects addressed and the production processes, there has been a notable change in the aesthetic of the films.

The audiovisual identity of the two films meets the requirements of formal minimalism (here the work of Javier Aguirre, cinematography, and Mike Serrano, art direction, should be underscored) and moves away from the more baroque proposals we find in other Basque films.

Finally, we can affirm that it is the confluence of everything described above that has led to the commercial success and international recognition of the two films (above all Loreak).

\section{Bibliography}

Amat Francisco, A. and L. Moliner Miravet. "Porque la visibilidad importa: una propuesta para trabajar la diversidad sexual en la ESO a través de la educación en medios." Revista de Educación Inclusiva, Vol. 4, 2011, pp. 149-160.

Barambones Zubiria, J. "Una mirada telescópica al cine en euskera: versiones originales, dobladas y subtituladas." Hermeneus: Revista de la Facultad de Traducción e Interpretación de Soria, Vol. 13, 2011, pp. 25-59.

De Pablo, S. Cien años de cine en el País Vasco. Vitoria: Diputación Foral de Álava, 1996.

Díez, A. R. "Loreak [Reseña de la película" Loreak" de Jon Garaño y José Mari Goenaga]." Papeles del CEIC, International Journal on Collective Identity Research, Vol. 1, 2016, pp. 17.

Macías, J. “Cine vasco: ¿Un debate cerrado?.” Zer-Revista de Estudios de Comunicación, Vol. 15(28), 2011, pp. 31-48.

Manias, M. "Euskerazko fikziozko zinemaren susperraldi hauskorra (2005-2012)." Ikusgaiak Cuadernos de cinematografía, Vol. 8, 2013, pp. 85-108.

Martínez, Josu. Gure (zinemaren) sor lekua: euskarazko lehen filmaren aurkikuntza, historia eta analisia. Bilbao: UPV/EHU Argitalpen zerbitzua/Servicio Editorial, 2015.

Morales, S. T. "Ni tiranos ni esclavos. Ama Lur (1968-2008)." Revista internacional de los estudios vascos RIEV, Vol. 54(1), 2009, pp. 117-145. 
Rincón, A. "Loreak. Un film de Jon Garañano y José Mari Goenaga (2015)" [Reseña audiovisual]. Papeles del CEIC, International Journal on Collective Identity Research, Vol. 17(1), 2016.

Roldán Larreta, C. “Antton Ezeiza en el debate Cine-Euskera.” Fontes linguae vasconum: Studia et documenta, Vol. 29(74), 1997, pp. 129-142.

Roldán Larreta, C. "Euskera y cine: una relación conflictiva." Fontes Linguae Vasconum, Vol. 71, 1996, pp.163-176.

Roldán Larreta, C. El cine en el País Vasco; desde Ama Lur (1968) a Airbag (1997). Donostia: Ikusgaiak. Cuadernos de cinematografía 3, 1999.

Torrado, S. "La evolución histórica del concepto de cine vasco a través de la bibliografía." Sancho el Sabio, Vol. 21, 2004, pp. 183-210.

Unsain, J. M. El cine y los vascos. San Sebastián: Eusko Ikaskuntza/Sociedad de Estudios Vascos, 1985.

Zunzunegui, S. El cine en el País Vasco: historia, práctica, teoría. Bilbao: Diputación Foral de Vizcaya, 1985.

\section{Internet sources}

Cabacas, E. (2014). “En los festivales internacionales no les importa si la película es en checo, en rumano, en euskera o en castellano, te van a tratar por igual". Lgecine. http://lgecine.org/2014/10/entrevista-jose-maria-goenaga-y-jongarano-directores-deloreak/ (3 August. 2016).

Siadeco/Basque Goverment. "Informe del Valor e Impacto Económico del Euskera”. 2015. http://www.euskara.euskadi.eus/contenidos/noticia/euskara_pib_4_2/ es_def/adjuntos/Euskararen_\%20eragin_ekonomikoa_Txostena_20151026. pdf. (3 August. 2016)

Muñoz, J. "Manifiesto Glocal Cinema: big stories, small countries". 2015. https:// www.irekia.euskadi.eus/uploads/attachments/6938/Manifestua_gaztelaniaz_. pdf?1442915013. (4 August. 2016)

"Lisbon Treaty". 2017. https://www.boe.es/legislacion/enlaces/documentos/ue/ Trat_lisboa.pdf. (5 August. 2016)

Website of the film Loreak: http://www.loreakfilm.com/es/. (2 September. 2016)

Website of Glocal Cinemas network: http://www.glocalcinema.com/. (12 July. 2016)

Ph.D. Thesis

Manías, M. (2015). Euskarazko zinemaren produkzioa eta finantziazioa (20052012): hamaika fikziozko film luzeren azterketa ekonomikoa. 


\author{
Paulina Cichoń \\ Institute of Ethnology and Cultural Anthropology, \\ University of Lodz, Lodz, Poland
}

\title{
6. The image of living of local people in the film Timbuktu: Between the literal and the symbol
}

\begin{abstract}
This chapter is an analysis of the Abderrahmane Sissako latest movie Timbuktu in the perspective of symbolic and interpretive anthropology. The author analyzes the meanings and symbols referring to myths, African traditional beliefs and contemporaneity hidden in the poetics of images. This analysis in view of a deeper cultural understanding ends with a conclusion that Timbuktu carries a universal content: it speaks to us, but also it says something about us.
\end{abstract}

Keywords: Timbuktu, Abderrahmane Sissako, interpretive anthropology, symbol, myth, African culture, terrorism

\section{Introduction}

Vivian Sobchack, film theoretician writing on the phenomenology of cinema, in one of her latest book says that:

Whether or not we go to the movies... we are all part of moving-image culture and we live cinematic and electronic lives. Indeed, it is not an exaggeration to claim that none of us can escape daily encounters - both direct and indirect - with the objective phenomena of photography, cinematic, televisual and computer technologies and the network of communication and texts they produce. It is also not an extravagance to suggest in the most profound, socially pervasive, and yet personal way, these objective encounters transform us as embodied subject ${ }^{1}$.

In other words, "moving-image culture" has an enormous impact on our daily life. Not only does it affect our imagination, but it also defines what is important and what is not. It sets the trends and living standards and influences our beliefs, opinions and identity - the way we see "Ourselves" and "The Others." What should be emphasized- texts that contemporary media produce "transform us as

1 Vivian Sobchack, Carnal Thoughts: Embodiment and Moving Image Culture (Berkeley: University of California Press, 2004), s. 136: 20 Jan. 2017 https://monoskop.org/ images/5/58/Sobchack_Vivian_Carol_Carnal_Thoughts_Embodiment_and_Mov ing_Image_Culture.pdf 
embodied subjects." This statement provokes the question "how deeply can this transformation change individuals and society"; in fact, this is an important question about the role of "moving-image culture" in general - can it be a powerful tool for emancipation or does it rather strengthen stereotypes and exclusion? In this chapter, I would like to look at the story of local people told by Abderrahmane Sissako - a Mauritanian director, whose all cinematographic works aim at eliciting the shared destiny of Africans in the present, a destiny linked to a deterritorialized identity ${ }^{2}$. As Douglas Kelner notes:

Media culture can be an impediment to democracy to the extent that it reproduces reactionary discourses, promoting racism, sexism, ageism, classism, and other forms of prejudice. But media culture can also advance the interests of oppressed groups if it attacks such things as racism or sexism, or at least undermines them with more positive representations of race and gender ${ }^{3}$.

The story that Abderrahmane Sissako tells in Timbuktu, his latest film nominated for an Oscar, fulfills this second role mentioned in the previous quotation - that art is the way to create a universal language, common for every human being. Despite the fact that the plot is set in the exotic context of Mali, the director translates the events in the film in such a poetic and convincing way that the lives of the protagonists and the hardships they go through are convincing and effective in the emotional power they represent. Thus, his work, using the term proposed by Mary Louise Pratt, can be named as an "autoetnography" world. Global/local, center/periphery, national/transnational, outsiders/insiders, "postcolonial identity," the making of homes away of homes, language barriers all of these transcultural predicaments for the modernity are contemplated in Sissako movies. This dilemma is close to contemporary anthropology as it postulates a more reflective and deeper, cultural understanding of the identities in the context of globalization ${ }^{5}$. The question is: what new anthropological perspective

2 Michelle Stewart, "Abderrahmane Sissako: Les Lieux Provisoires of Transnational Cinema," in: Film, History, and Cultural Citizenship, ed. Tina Chen and David Churchill (New York: Routledge, 2007), pp. 199-216.

3 Douglas Kellner, Media Culture: Cultural Studies, Identity and Politics between the Modern and Postmodern (London; New York: Routledge, 2003), p. 4.

4 See Mary Louise Pratt, Imperial Eyes: Travel Writing and Transculturation (New York: Routledge, 2008).

5 See Clifford Geertz, Local Knowledge: Further Essays in Interpretive Anthropology (New York: Basic Book, 1983) or James Clifford, Routes. Travel and Translation in the Late Twentieth Century (Cambridge, Massachusetts; London, England: Harvard University Press, 1997). 
can be provided to film's interpretation or to what extent can a movie be an interesting material to research for anthropology? The simplest answer seems to be that cinema is a part of culture. As noted by Aleksander Jackiewicz, precursor of anthropology of film in Poland:

The material of the film are the images of registered reality... In this material, not only in ways of operating them, there are a lot of 'traces' of man, his world, culture. So literally impressed human fate in work, with all the biological, natural characteristic, there is in no art. If anthropology is one of the forms of our kind's awareness, the film can be valuable material for her ${ }^{6}$.

Anthropological perspective can also be valuable in interpretation, because of:

...specific bipolar nature of anthropological perception simultaneously focused on the archaics, the structure of long duration, and the contemporary. In this case too we are not dealing with the blurring of differences and extremities, just as in the equally concise definition of ethnography: Ethnography is a science about that, which connects people of different societies, cultures and epochs ${ }^{7}$.

Taking the above statements into account, the aim of this chapter is to look at the film Timbuktu not only as a record of contemporaneity but foremost to show what eternal mythological motifs and deep symbolic structures are hidden behind the poetics of images. In other words, what happened on the screen - the sensual experiencing of the actual perception of things (literal) and what goes beyond the frame of the movie and leads to something else (symbol).

\section{In the "real" and symbolic worlds}

When in 2012 the eyes of the world turned to the Olympic Games in London, in one of local newspapers Sissako read about the public execution of the woman and the man who were sentenced to death by stoning for having children outside wedlock - one of the heaviest sins according to the terrorist organization Ansar al-Dine. Ansar Dine (Ançar Dine, Ansar al-Din, Ansar ul-Din) is an armed Islamist movement of the Salafi-jihadi strain, formed toward the end of 2011 by a veteran Tuareg rebel leader of 1990s named Iyad ag Ghaly. Ansar Dine fought in 2012 along with the National Liberation Movement of Azawad (MNLA) in the uprising in Mali. However, the Ansar al-Din in contrast to MNLA hadn't

6 Aleksander Jackiewicz, Antropologia filmu (Kraków: Wydawnictwo Literackie, 1975), p. 15.

7 Zbigniew Benedyktowicz, "Antropologia filmu," Kwartalnik Filmowy, Vol. 2 (1993), p. 17. 
fought for the independence of Azwad but to establish Sharia law in Mali. In 2012, the organization took hostage most cities in Mali, including the historical city Timbuktu. ${ }^{8}$. The public execution of the couple became a direct inspiration for Abderrahmane Sissako to portray life under terror experienced every day. As the director says in one of the interviews:

Their execution was posted online and this unspeakable atrocity took place without the media or the world noticing. This couple whose names we don't even know became a symbol. There is little interest in a tragedy that happens so far away, but not to pay attention would be to ignore that the earth is round; what happens far away isn't that far from home. People say: it's a scandal, why aren't people talking about this but they don't know what to do about it. I am one of those people that complains that no one is exposing such horrors but I'm also an artist, a filmmaker and my role is to be a conduit for some of that collective conscience of rebellion ${ }^{9}$.

Someone might think that the film will be another brutal drama about barbarian terrorism and its victims. Mostly, in media discourse, the phenomenon of religious terrorism and the heinous actions that it carries is considered in the context of numbers, places and new attacks. The numbers frighten and evoke a sense of fear and terror in us. We are overwhelmed by news about furious people, who in the name of religion dedicate lives to taking away the right to life of innocent victims. So, it is a discourse based on what Said called figuration - "we-they"10. In the world dominated by the media, this opposition seems to be simple - terrorists are Said's "they" - irrational, impetuous and unpredictable barbarians coming from the circles of Islam culture. We are a rational world of the West, whose mission is to fight terrorism, the mission intensifying when terrorism crosses its borders and directly threatens interests of the West. Mass media which belong to the "tests of culture" creating the knowledge of the world play a crucial role in the projecting of the figure "we-they." By essentializing and exaggerating the nature of "the other," they promote a specific vision of the world and influence the collective image of Islam, which treated as a monolith connotes an obvious association with terrorism. However, as Sissako shows, reality is more complicated internal conflicts, mass reconfigurations of human world resulting in new forms

8 For the insightful analysis of the conflict in Mali, see: Krzysztof Danielowicz Terroryzm w Afryce: geneza oraz przebieg konfliktu w Mali w latach 2012-2014 (Oświęcim: Napoleon V, 2016).

9 Abderrahmane Sissako, "An interview" (2015): 20 Jan. 2017 http://www.con versationsaboutcinema.co.uk/ioc/timbuktu/671/a-film-is-a-conversationinterview-with-abderrahmane-sissako/

10 Edward Said, Orientalism (London: Penguin Group, 2003). 
of citizenship and belonging, ethnic and religious divisions, local beliefs and above local content exchanges evade precise definitions and descriptions. They need another language, a deeper reflection and a search for new forms of expression in order to think about "We" and "They" in the context of the ambiguity of this dichotomy.

Media moreover, do not explain, do not problematize reality, but deal with guilt and responsibility. In other words, media coverage concerning religious terrorism is totally dehumanized. Abderrahmane Sissako in his work reverses this narrative. Not only does he show what is hidden behind numbers - ordinary people with their needs, beliefs, passion forced to live against their tradition (what usually escapes the attention of the media) - but also he "gives face" to "Islamic fundamentalism" and individuals, who withstand the terror, so demonized in the media. He both undermines Western stereotypes about Islam, jihad or Islamic fundamentalists and emphasizes what is universal to all, regardless of race, religion or language. Changing the optics in the way of presentation, the conflict portrayed in the film destabilizes our ideas about Islam, forces us to reinterpret them and leads us to deeper reflection. As was written in one of the film reviews:

Timbuktu is a film that should be urgently seen by audiences everywhere as it engages with a range of pressing issues, not least the application of laws justified by extremist religious doctrine. Now, over a year since its acclaimed screening at the Cannes film festival, it is a work that gains added pertinence with the growth of religious extremism across the globe. What is particularly interesting to us is that rather than choosing to create a film of great drama and conflict, in Timbuktu even a potentially tense scene of the transfer of a western hostage is given the aura of being an unremarkable and commonplace activity, Abderrahmane Sissako has chosen to create a work that focuses on the imposition of a version of Islamic law on the everyday, almost banal, aspects of daily life in and around Timbuktu ${ }^{11}$.

Those "banal aspects" of daily life - singing together, playing football, praying to one's "own" gods, eating dinner with family - merge and interlace in reality, which gives spectators a feeling that what is so far away is paradoxically close at the same time. By connecting us to different stories of "ordinary people," on the one hand, the director creates an impression that everyone can relate to the protagonists' life, and, on the other hand, he draws global attention to the suffering of the local people.

11 Andy Wills and Shivani Pall, "Timbuktu" (2015): 20 Jan. 2017 http://www.con versationsaboutcinema.co.uk/ioc/timbuktu/711/culture-under-siege-everydaylife-in-timbuktu/ 
Not coincidentally the plot of the story is set in Timbuktu - an intellectual and spiritual capital and a center for the propagation of Islam throughout Africa in the fifteenth and sixteenth centuries, and the UNESCO World Heritage Site. An old Islamic proverb from West Africa proclaims: "Salt comes from the north, gold from the south, and the word of God and the treasures of wisdom from Timbuktu"12. According to one tradition, Timbuktu was named for an old woman left to oversee the camp while the Tuareg roamed the Sahara. Her name (variously given as Tomboutou, Timbuktu or Buctoo) meant "mother with a large navel"13. That myth seems to be possible, because in traditional beliefs omphalos was the center of the body. The world in an archaic culture has its own navel, the central point from which began and spread further space. In that place, there was a central axis and people saw opening communication between the three levels of space: the earth, the sky and the realm of the underworld. The center of the world (axis mundi) is not a geographical place but mental and symbolic ${ }^{14}$. To destroy the culture, first strike its symbol.

Symbols have always played a tremendous part in the cultural and social lives of specific communities, be it territorial, religious, cultural or other. The consistency of symbolic universe is a need of every human being as it guarantees the order of reality and a feeling that one occupies one's own world. Although symbols are individually interpreted, in traditional cultures they are manifested and experienced communally. The breakdown of a symbolic universe results in the loss of sense and quality as well as the communal meaning, the expression of which are symbols. Depriving of a human being of "the sense of being in the world" means the creation of a new order anew. So, the attack on Timbuktu - a cultural symbol of Mali - is not associated only with a physical invasion and takeover of the city but also with the destruction of the spiritual and material continuity of the city community.

The film is about a family from Tuareg who lead a quiet life at the outskirts of the city. The director shows us the beauty of the deserts at the borders of which they live. The family composed of Kidane (Ibrahim Ahmed) the shepherd, his wife Satima (Toulou Kiki) and his beloved daughter (Layla Walet Mohamed) take care of everyday duties during the day while they spend their evenings

12 Wojciech Pastuszka, “Timbuktu. Miasto tysięcy manuskryptów” (2006): 20 Jan. 2017 https://archeowiesci.pl/2006/11/12/timbuktu-miasto-tysiecy-manuskryptow/

13 Michał Tymowski, Dzieje Timbuktu (Wrocław: Zakład Narodowy imienia Ossolińskich, 1979), p. 14.

14 Mircea Eliade, Traktat o historii religii, trans. Jan Wierusz-Kowalski (Łódź: Wydawnictwo Opus, 1993), pp. 356-367. 
singing, dancing and enjoying conversations under starry skies. Sissako builds this intimate portrait of a happy family living in peace and in harmony with nature by applying artistic shots, slow camera movement, quiet music fading into the background and short almost whispered dialogues. However, in later film sequences, the spectator realizes that behind these idyllic scenes with all their symbolic and poetic layers, dramatic stories hide. Slowly, the reality of horror reaches Kidane family as well: all the prohibitions exert a huge impact on all the inhabitants of Timbuktu, including Kidane family. Newly enforced rigorous Sharia law acquires the look and feel of a grotesque aptly illustrated by a scene when a fish merchant is ordered to wear gloves when selling fish. She asks a question: "to put gloves on when selling fish? So how can I pour water on this fish with my gloves on?" (dialogue from Timbuktu).

Sissako seems to be condemning literal interpretations of Koran by oppressors. Peace and an idyllic portrayal of the shepherd family, who appear a metonymy of life in harmony with the rhythm of the desert, gives way to fear for one's life. The internal anxiety of Kidane and Satima grows almost in a linear fashion along the power of terror when the initial timidity of oppressors changes into cruelty. The only person who is spared is the local shaman woman. It seems that oppression will not reach the family because they live at the outskirts of the city where the desert constitutes a protective barrier. This safe status of the family is maintained until Kidane gets into conflict with Amadou, the fisherman whom he accidentally fatally hurts. Despite the fact that Kidane repeats constantly that one cannot escape fate and that everything lies in the hands of God (Timbuktu), right after the accidental death of the fisherman, the fate of Kidane depends on the fighters who rely on their own code of rules. As already noted, Kidane family life constitutes the main axis of the plot, nevertheless the director skillfully introduces other subplots, other stories that illustrate the conditions of life under terror experienced by the inhabitants of Timbuktu every day. These stories not only draw our attention to the real events that took place in northern Mali, but also reveal other content, senses and symbolic meanings. The film becomes doubly referential. According to the double-track anthropological perspective, whereby one track deals with the archaic, with the structure of longevity, and the other with contemporaneity, I will try to interpret the symbolic layers of Sissako's film.

Timbuktu begins with silence and the sound of wind in the desert. The camera lens moves to the running antelope. It seems that we hear her breathing rapidly (il.1). In the background someone utters the words - "Do not kill, only torment." The next scene shows a series of shots pointed at African cult figures. 
As Sławomir Sikora, writing on visual anthropology, especially photography, noted about photographs, the observation that can be easily applied to film shots:

Some photographs are symbolizations as they transcend its realistic qualities, not losing it after all. In this duality they become specific symbols, whereby the meaning of the first image is necessary to understand the meaning of the second one $\mathrm{e}^{15}$.

As far as the interpretation of film images is concerned, we may say that what happens on the screen goes beyond the frame and causes a whole range of reactions, meanings and values. Semantic openness and variation in the image creates multiplicity of meanings one can deduct from them. When reading a scene in a more obvious way, we can presume that a running antelope might symbolize freedom for local people who are forbidden music, dance, a sense of security, integrity and identity. But why did the director start the film story from an image of an antelope, not any other animal? This image may lead us to traditional beliefs and meanings ascribed to an antelope in local mythology. According to one legend of Bambara people - an ethnic group living at the borderland of Mauritania and Mali - one day there appeared an antelope Cziwara - a mythical creature, half human and half animal. She came down from heaven to teach people how to grow grain. But people forgot about her charitable deeds and the angry Cziwara hid in a deep pit. To appease it, the Bambara tribe began to make masks symbolizing the sacred animal. Antelope's ears represent the songs sung by women during the most difficult time for the tribe, the aim of which is to help survive hard times ${ }^{16}$. Both scenes, one with an antelope and the other with figures of cult, might signify not only a symbolic shooting but also an escape from an unsuccessful process of decolonization and from internal divisions.

Internal conflicts present in Malian society are also gently outlined by Sissako. The symbol of division between Tuaregs who live in the North (represented by Kidane, a herdsman) and ethnic groups of Black Africa in the South (represented by Amadou, a fisherman) became a river - a border between our world and an alien world.

In traditional, archaic cultures based on magical thinking, a person who crossed the river, a border between "orbis interior" ("our world") and "orbis exterior" ("foreign world"), risked some sort of danger. Borders are often thought to be ambivalent - transcendental and demonic at the same time, and, human order

15 Sławomir Sikora, Fotografia: między dokumentem a symbolem (Warszawa: Świat Literacki, 2004), p. 99.

16 For insightful myth knowledge, see: Zygmunt Komorowski, Kultury Czarnej Afryki (Wrocław: Ossolineum, 1994). 
does not apply to them. A man on the border finds himself in a "borderline" place signed by "tabu." As Kowalski puts it "A hasty, illegal crossing of the border has to end for the risk-taker with the worst consequences: death, insanity or sinking in alien world and assuming its identity" ${ }^{17}$. Probably Satima, the shepherd's wife, anticipated inevitable consequences when in the scene preceding the incident taking place at the Niger river, she asks her husband not to take any weapons but only to talk to the fisherman.

Music, as Bambara's myth, can help survive hard times and as such it constitutes a significant part of the film serving as an exemplification of peaceful resistance to the regime's torturers. Dunduzu Chisiza one of African's politicians says:

Another outstanding characteristic of our culture is our love for music, dance and rhythm. Our throats are deep with music, our legs full of dance while our bodies tremor with rhythm. The proper subtitle for Africa should have been "Land of music, dance and rhythm". This three-pronged phenomenon is indeed the spice of our life ${ }^{18}$.

Dance and music - a tribute to local heritage, an everyday expression of feeling, a key part of the culture of nomadic people in the region - can be purifying and liberating. Once again, the director refers to spiritual beliefs by presenting Zabou, possibly a local shamanistic priestess walking around in brightly covered robes with her head and hands uncovered and a cockerel on her shoulder.

Zabou, a transcendent figure - a mediator between earthly world and underworld - is the only woman Jihadi soldiers allow not to cover her hands and head. The scene during which we get to know Zabou is greatly symbolic. The warriors get into town and begin to "patrol" Timbuktu's streets. In one of the streets a shaman woman stands with spread arms against the car of the warriors. It would seem that the warriors are not going to pay attention to the shaman woman and will fulfill their patrolling mission nevertheless. However, when the fearless Zabou does not withdraw, they slowly go away. We could limit our interpretation of Zabou's role as that of resistance and rebellion, but such a reading of this scene seems insufficient. The director shows the power of resistance in many other scenes in the film; likewise, Zabou also appears in another powerful scene. In the reading

17 Piotr Kowalski, "Niezróżnicowanie, czyli nasza byle jaka katastrofa," in: Powodzie, plagi, życie i inne katastrofy, ed. Konarska Katarzyna (Wrocław: Colloquia Anthropologica et Communicatica, 2012), pp. 7-26.

18 Dunduzu Kaluli Chisiza, "The Temper, Aspiration and Problems of Contemporary Africa," Nyasaland Economic Symposium, July 18-28, 1962, as cited in Primus, "African Dance," in: African Dance. An Artistic, Historical, and Philosophical Inquiry, ed. K. W. Asante (Canada: Africa World Press, 1996), p. 9. 
of this particular figure, we have to turn to the area of bipolar anthropological view, that is, magical thinking. This is not about obvious analogies but rather, as Piotr Kowalski notes, "The discovery of cultural mechanisms which, in the changing historical conditions, construct the world anew" ${ }^{19}$. The borderline figure of Zabou has the power characteristic of those who are "in between," those who are in contact with "sacrum." In archaic cultures, "the other" generate ambivalent feelings because they represent the state of matters that are not contained by the order of this world and, moreover, nobody knows where this "otherness" comes from. These matters cause fear and fascination at the same time because sacrum itself is frightening, it is holy and demonic simultaneously, good and bad at the same time. Everything that happens to be "in between" is hybrid and constitutes a threat to the real tidy world. Initially, the warriors try to evade the woman, but for one of them, the fascination with sacrum is stronger than he thought. There is one scene in the film, which can be interpreted as "a rite de passage," when one of the soldiers, away from his comrades, performs an expressive barefooted dance that seems to represent a kind of primeval connection, a spiritual desire to clean himself. He engages in an ecstatic dance that would illustrate a symbolic meaning of "ecstasy which is the time of exceptional rapture during which no conditions of ordinary everyday life are important any more (...) a human being in the state of ecstasy is someone who went beyond his body and the physical limitations of his body"20.

This "initiation" comes in the presence of the woman, just after she has broken a mirror. According to traditional beliefs a broken mirror is not an ominous prophecy but it heralds things much worse - the smashing of mirrors, breaking into pieces the image contained therein, means damage to man or the world ${ }^{21}$. In this damaged world, the only thing that is left is the power of imagination - here we come to the much-commented scene that shows a group of young men playing football match without a ball in a totally committed way. Abderrahmane Sissako comments on this part of the film in an interview:

Imagination is the last weapon for people who have lost all their bearings. This is what keeps them alive because nobody can do anything about it; it's the ultimate hope ${ }^{22}$.

19 Kowalski, "Niezróżnicowanie, czyli nasza byle jaka katastrofa," p. 11.

20 Kowalski, "Niezróżnicowanie, czyli nasza byle jaka katastrofa”" p. 9.

21 Piotr Kowalski, Kultura magiczna. Omen, przesąd, znaczenie (Warszawa: Wydawnictwo Naukowe PWN, 2007), p. 290.

22 Sissako, "An interview." 
Sissako not only portrays various peaceful forms of resistance of those who refuse to submit to a religious devotion hijacked by fanatic interpretation of Sharia law but also depicts jihadists as morally complex people, and exposes internal conflicts and hypocritical behavior in various forms. In the scene of recording propaganda film to gain new recruits, a young boy, who used to be a rapper, is trying to convince (perhaps more himself) that he walked a path of sin. He says that to the camera with a complete lack of conviction and to the question of older soldiers, "Does he believe in what he says" he replies, "I do not think so." This image seems to say with the words of Miron Białoszewski: "Look at me, so I guess I have a face. Of all the familiar faces I remember my own the least"23. The overall message of the film seemed controversial, but Sissako explains in one of his interviews for $\mathrm{Al}$ Jazeera:

The movie aims at condemning all forms of barbarism and efforts to cover up the truth. These people are condemned because of what they do. But I gave them some humanity because if you don't, the risk is that you will lose your own humanity... In my opinion there is always something to be saved in a human. Art must recognize what can save someone from going down the wrong path. But the group effect is condemnable (Sissako, Talk to Al Jazeera)

Finally, one of the most important protagonists in the film is the local Imam mediator between local residents and terrorists. When a jihadist enters the mosque with weapons, he addresses them in the following way:

Here in Timbuktu, people who devote themselves to religion fill it with the head, not weapons. Stop your jihad. You dishonor Islam and others. Where is your mercy? Where is your forgiveness? ${ }^{24}$

This dialogue is not just a story about the real meaning of Islam for Muslims, but about Islam for the world and especially about religion for fundamentalists.

\section{Conclusion}

At the end of the chapter once again I would like to quote Sikora:

The film can be a very interesting means of exploration of cultural boundaries in the modern world. Because it allows dissect the boundaries between what is local and what is global; or rather, different levels of interpenetration of local and global; allows to observe the centrifugal and centripetal movement ${ }^{25}$.

23 Miron Białoszewski, Autoportret odczuwalny, Obroty Rzeczy (Warszawa: Państwowy Instytut Wydawniczy, 1957).

24 Dialogue from Timbuktu.

25 Sikora, Fotografia: między dokumentem a symbolem, p. 183. 
Despite its local context, Timbuktu carries universal content: not only does it speak to us, but it also communicates something about us. The images that emerge from the frames painted by the director's sensibility become stories about the human experience of the world, its fragmentation, the lost unity and the integrity of being. In the final scene of the film, the running antelope appears in the frame again. It runs for a moment as if running failed to exhaust her as it runs toward freedom. A film is always only a reflection of reality, its metonymic reflection, but the work of Abderrahmane Sissako is a whole "book of quotations" from which everyone can choose the one most moving to him and everyone can read it in their own way. Timbuktu is an invitation to a dialogue - so much needed in today's world full of conflicts and mutual prejudices.

\section{Bibliography}

Benedyktowicz, Zbigniew. "Antropologia filmu," Kwartalnik Filmowy, Vol. 2, 1993, p. 17.

Białoszewski, Miron. Autoportret odczuwalny, Obroty Rzeczy. Warszawa: Państwowy Instytut Wydawniczy, 1957.

Chisiza, Kaluli, Dunduzu. "The Temper, Aspiration and Problems of Contemporary Africa," Nyasaland Economic Symposium, July 18-28, 1962, as cited in Primus, "African Dance." In: African Dance. An Artistic, Historical, and Philosophical Inquiry, ed. K. W. Asante, Canada: Africa World Press, 1996, p. 9.

Clifford, James. Routes. Travel and Translation in the Late Twentieth Century. Cambridge, Massachusetts; London, England: Harvard University Press, 1997.

Danielowicz, Krzysztof. Terroryzm w Afryce: geneza oraz przebieg konfliktu w Mali w latach 2012-2014, Oświęcim: Napoleon V, 2016.

Eliade, Mircea. Traktat o historii religii. Trans. Jan Wierusz-Kowalski. Łódź: Wydawnictwo Opus, 1993.

Geertz, Clifford. Local Knowledge: Further Essays in Interpretive Anthropology. New York: Basic Book, 1983.

Jackiewicz, Aleksander. Antropologia filmu. Kraków: Wydawnictwo Literackie, 1975.

Kellner, Douglas. Media Culture: Cultural Studies, Identity and Politics between the Modern and Postmodern. London; New York: Routledge, 2003.

Komorowski, Zygmunt. Kultury Czarnej Afryki. Wrocław: Ossolineum, 1994.

Kowalski, Piotr. Kultura magiczna. Omen, przesą, znaczenie. Warszawa: Wydawnictwo Naukowe PWN, 2007. 
Kowalski, Piotr. "Niezróżnicowanie, czyli nasza byle jaka katastrofa." In: Powodzie, plagi, życie i inne katastrofy, ed. Konarska Katarzyna. Wrocław: Colloquia Anthropologica et Communicatica, 2012, pp. 7-26.

Pastuszka, Wojciech. “Timbuktu. Miasto tysięcy manuskryptów”, 12 Nov. 2006, https://archeowiesci.pl/2006/11/12/timbuktu-miasto-tysiecy-manuskryptow/ (20 Jan. 2017)

Pratt, Mary, Louise. Imperial Eyes: Travel Writing and Transculturation. New York: Routledge, 2008.

Said, Edward. Orientalism. London: Penguin Group, 2003.

Sobchack, Vivian. Carnal Thoughts: Embodiment and Moving Image Culture, Berkeley: University of California Press, 2004. https://monoskop.org/ images/5/58/Sobchack_Vivian_Carol_Carnal_Thoughts_Embodiment_and_ Moving_Image_Culture.pdf (20 Jan. 2017).

Sikora, Sławomir. Film i paradoksy wizualności. Praktykowanie antropologii, Warszawa: Wydawnictwo DiG, 2012.

Sikora, Sławomir. Fotografia: między dokumentem a symbolem, Warszawa: Świat Literacki, 2004.

Sissako, Abderrahmane. "An interview," 28 May 2015, http://www.conver sationsaboutcinema.co.uk/ioc/timbuktu/671/a-film-is-a-conversationinterview-with-abderrahmane-sissako/ (20 Jan. 2017)

Sissako, Abderrahmane. “Talk to Al Jazeera, Timbuktu: Was Islam taken hostage," 30 Aug. 2015, http://www.aljazeera.com/programmes/talktojazeera/2015/08/ sissako-islam-timbuktu-hostage-150828072104792.html (15 Jan. 2017)

Stewart, Michelle. "Abderrahmane Sissako: Les Lieux Provisoires of Transnational Cinema." In: Film, History, and Cultural Citizenship, eds. Tina Chen, David Churchill. New York: Routledge, 2007, pp. 199-216.

Tymowski, Michał. Dzieje Timbuktu, Wrocław: Zakład Narodowy imienia Ossolińskich, 1979.

Wills, Andy and Pal, Shivani. “Timbuktu”, 1 June 2015, http://www.con versationsaboutcinema.co.uk/ioc/timbuktu/711/culture-under-siegeeveryday-life-in-timbuktu/ (20 Jan. 2017) 



\section{Part 2: Gender and Sexuality}





\title{
Jana Dudková
}

\section{Institute of Theatre and Film Research, Slovak Academy of Sciences}

\section{Tourists, migrants and travellers: The role of women in reshaping Slovak (cinematic) identity ${ }^{1}$}

\begin{abstract}
The chapter focuses on changes in representations of (or attitudes to) journeying and international mobility as seen through post-socialist phase of the Slovak cinema, namely its fiction film. These changes were made more visible especially through generational exchanges, thanks particularly to debuts and second films by debutants of the respective decades. What is particularly interesting here is, nevertheless, the role of women in shaping new attitudes to international mobility. Due to the crisis of Slovak cinema during the 1990s, many male directors ended up in advertising industry, leaving the space for the emergence of the first two strong generations of female directors in the history of Slovak cinema. The chapter examines how these women responded to the image of national cinema built up by debutants of the 1990s, how they abandoned (but at the same time made indirect homages to) generations of their teachers and how they intuitively used their female, cautious and existential stance to the new possibilities of East-West mobility - but at the same time indirectly helped to establish more assertive images of international travellers.
\end{abstract}

Keywords: Women directors, images of journeying, international mobility, post-socialist cinemas, Slovak cinema, generational exchanges, debuts

The negative experience of travelling, migration and international mobility is a common feature of most of the cinemas of Eastern and South-Eastern Europe. In some cases, the concept of migration as a traumatic experience, together with unclear regional identity (mostly shaped by Western optic and even Western travelogues), paradoxically leads to a frequent exploitation of journey, travelogue or diaspora narratives. ${ }^{2}$ In others, the traditionally sedentary way of life motivates the hesitation to travel.

In her article "Staying Home and Safe: Czech Cinema and the Refusal to be Transnational," film scholar Petra Hanáková points out "the notable and surprising

1 This work was supported by the Slovak Research and Development Agency under the contract no. APVV-0797-12.

2 Dina Iordanova, Cinema of Flames. Balkan Film, Culture and the Media (London: British Film Institute, 2001), p. 263. 
absence or a conspicuous stigmatisation of motifs and themes dealing with international travel or migration in Czech, or more broadly Czechoslovak, cinema," and suggests a peculiar tendency to employ "confused wandering and even an essential disposition towards stasis" as "the core of the movements and travels" depicted already in the films of the Czechoslovak new wave in the 1960s. ${ }^{3}$

In this chapter, I would like to examine the topic of international migration and travelling in Slovak films after 1989, especially with regard to the role of women in reshaping the Slovak cinema. The reason is that the more positive approach to travelling appears not earlier than in new millennium, with emergence of a new generation of female debutants. At the time when international travelling starts to be perceived as more natural by younger generations of Slovaks, most of the male directors move to television or advertising industries. Nevertheless, even the female stories share some marks of hesitation to travel typical for older, almost exclusively men-directed narratives. Thus, even these stories prove the dominance of traditional, at the same time patriarchal and isolationist rhetoric of Slovak cinema.

On the one hand, it is tempting to link this hesitation to see international mobility and travelling as a positive experience with post-World War II history of the region when travelling abroad was often politically stigmatised. But as Petra Hanáková suggests, the more important roots of it could be found in historically much deeper patterns of thinking, including the revivalist imagination with its figure of a nation as a garden and intellectual/artist as a gardener. ${ }^{4}$

The most explicit example of the interrogation of this tradition, within the whole "Czecho-Slovak" film context, is the 1995 Slovak film Záhrada (The Garden) by Martin Šulík with its intertextual references to various national revivalist texts as well as to famous figures of "western" European modernism (Rousseau, Wittgenstein, St. Benedict, etc.). ${ }^{5}$

3 Petra Hanáková, "Staying Home and Safe: Czech Cinema and the Refusal to be Transnational," in: European Cinema after the Wall: Screening East-West Mobility, eds. Leen Engelen and Kris van Heuckelom (Lanham: Rowman \& Littlefield, 2013), p. 113 and onwards.

4 Hanáková, "Staying Home."

5 For more about this topic see Zuzana Gindl-Tatárová, “The Garden," in: The Cinema of Central Europe, ed. Peter Hames (London, New York: Wallflower Press, 2004), pp. 245-253; for more about the idyllic nature of the central spatial metaphor in Šulík's third film see: Vlastimil Zuska, "Topos zahrady v Zahradě a jeho časoznakové implikace," in: Svet v pohyblivých obrazoch Martina Šulíka, ed. Marián Brázda (Bratislava: Slovenský filmový ústav, 2000), pp. 122-147, and Jana Dudková, Slovenský film v ére 
Similar to other post-socialist cinemas, the Slovak one also appeared sceptical when it came to a more positive embracing of the topic of international mobility even after the "opening of borders" in 1989. An entire generation of debutants from the 1990s reacted to the new travel opportunities with particularly strong scepticism, most systematically expressed in the films by Martin Šulík but obvious also in most of the other debuts of the decade. This is partly due to the fact that the first debuts still mirrored a feeling of inner paralysis typical for the late socialism and chaos of transformational times. That applies not only to those debuts that were indebted to dramaturgical plans of the ending 1980s (i.e. 1990 Okresné blues - District Blues by Juraj Bindzár and R.S.C. by Martin Valent), but also to Martin Šulík's debut Neha (Tenderness, 1991). Nevertheless, a more positive approach to travelling wasn't introduced into following debuts either, which can be interpreted also as a result of identification with a new "lost generation." ${ }^{6}$ In fact, the rest of debutants already entered a collapsing industry, in times of the increasing nationalism and political isolationism of authoritative Vladimír Mečiar's government (1992-1998, with a short pause in 1994). What appears striking here are, nevertheless, gender and generational differences (but also similarities) in approaching the topic of international mobility, as well as the case of what we can label as "symbolic capital" of feature-length fiction debuts.

transkulturality (Bratislava: Drewo a srd - Vysoká škola múzických umení, 2011), pp. 46-55; and for more about the impact of Šulík's conception of the garden on the contemporary Slovak cinema, see Jana Dudková, "Between the Center and the Margin: The Notion of Central Europe in Slovak Cinema After 1989," Iluminace, Vol. 25, No. 4 (2013), pp. 7-94 (especially the section "From Irony to Cynicism: From Gardens to Non-Places," pp. 82-87).

6 The term is, nevertheless, suggested by a journalist Miloš Krekovič post-festum, e.g. in a 2010 and 2012 articles on the phenomenon: Miloš Krekovič, "Stratená generácia?” SME (2010), 11 July 2017, https://kultura.sme.sk/c/5264969/stratena-generacia. html\#axzz4mXXL3U9j; and Miloš Krekovič, "Ako vzniká hit: Na krásnom modrom Dunaji,” SME (2012), 11 July 2017, https://kultura.sme.sk/c/6333328/ako-vznika-hitna-krasnom-modrom-dunaji.html\#axzz4m5AGELA6.

7 Slovak cinema was in transparently privatised since 1991 - with Šulík's debut as the last one produced by the state-run Koliba Film Studios. For more on the topic of political and economic history of privatisation of "Koliba," see Václav Macek, "1 297 254000 Sk," Kino-Ikon, Vol. 14, No. 1 (2010), pp. 125-154; and Martin Šmatlák, "Slovak Audiovisual Fund - A Brief History of Prolonged Time," in: Transformation Processes in Post-Socialist Screen Media, eds. Jana Dudková and Katarína Mišíková (Bratislava: Vysoká škola múzických umení v Bratislave - Ústav divadelnej vedy SAV, 2016b), pp. 11-20. 
In the group consisting of altogether nine debuts 8 and four "further" films by 1990s debutants made during the period 1990-2000 (actually, all of the latter being directed by Martin Šulík), the only film made by a woman is 1997 Modré $z$ neba (Blue Heaven) by Eva Borušovičová, conceived as a female variation on the plot of Šulík's third film The Garden.

Most of these films depict isolated and elitist social groups (artists, intellectuals, students, bohemians, flaneurs), and are driven by a hesitant or sceptical attitude to new possibilities of international mobility - expressed explicitly, indirectly by the plots (about voluntary isolation), or by introducing metonymical and thus unreal presence of supposed emigrants - such as Andy Warhol who appears as a symbolic "Slovak" ex-patriate in no less than two films, Šulík's second film Everything I Like and Semjan's debut On the Beautiful Blue Danube.

The most explicit expression of a hesitant stance towards international mobility can be found in Šulík's Everything I Like, where generational dilemmas of people who grew up in socialism are explained through the cameo role of writer Rudolf Sloboda who, in several staged pseudo-documentarian monologues, refers to unnecessary, tiring or even dangerous nature of travelling, while combining examples of Goethe or Immanuel Kant with experiences of his own acquaintances, or even his own catastrophic dreams (e.g. about getting lost and robbed in New York).

However hesitant the directors may be about the topic, Slovak cinema of the 1990s, nevertheless, does offer motives related to international mobility, travelling or intercultural exchange. It is just that most of them appear in films by older directors who managed to make their debuts in various periods before $1989 .{ }^{10}$ A star of the 1960s' Slovak New Wave, Juraj Jakubisko, in his Lepšie byt' bohatý a zdravý ako chudobný a chorý (It's Better to Be Rich and Healthy than Poor and

8 As a matter of fact, two of the 1990s' debuts were prepared in the pre-1989 period: District Blues and R.S.C. As the first genuinely post-communist debut, there appears Martin Šulík's debut Neha (Tenderness, 1991), followed by Na krásnom modrom Dunaji (On the Beautiful Blue Danube, 1994, dir. Štefan Semjan), Vášnivý bozk (Passionate Kiss, 1994, dir. Miroslav Šindelka), Hazard (1995, dir. Roman Petrenko), Modré z neba (Blue Heaven, 1997, dir. Eva Borušovičová), Tábor padlých žien (The Camp of Fallen Women, 1997, dir. Laco Halama) and, finally, Všetci moji blízki (All My Loved Ones, 1999, dir. Matej Mináč).

9 Andy Warhol is, nevertheless, an ethnic Ruthenian and his discovery by "patriotic" post-1989 public discourse in Slovakia is mocked in both of the films.

10 The only exception among the debuts is Martin Valent's R.S.C. which, in the manner of late socialism, refers to the decadent nature of East-West mobility, and to the topic of gastarbeiters abandoning their children, who, despite living in relative luxury, turn to moral decay. 
Ill, 1992) confronts emigration before and after the fall of the "iron curtain." In each case, it is motivated by the adventurous and fickle nature of the main male protagonist, albeit being justified by political attempts at restricting human freedom, including the rise of nationalism in public life at the beginning of the 1900s.

On the other hand, the box-office hits by Dušan Rapoš, Fontána pre Zuzanu 2 (The Fountain for Suzanne 2,1993) and 3 (1999) are also fixated on the topic of travelling. The first film transforms the original 1985 story of a socialist housing estate beauty Suzanne into a tale of truck drivers who are permanently on the road, including even a trip to Russia, while the second sequel offers a quasi-colonial narrative on Suzanne's journey to Africa with an "African-turned-Slovak" who tries to avoid his prearranged marriage with a local girl.

It is important to understand these are no exceptions. The entire decade is, in fact, characteristic for its absence of images of travelling as a natural phenomenon. In general, filmic Slovaks of the 1990s still do not feel like travelling, they search for freedom in their private, closed worlds. The topics of a life-on-the-road, migration or even emigration concern only adventurers or foreigners, who are clearly different from the rest of the population literally at first sight or by their accent (typical examples include the character of English lover from Everything I Like, or the "black-skinned" character portrayed by dancer and singer Ibrahim Maiga in The Fountain for Suzanne 2 and 3). The idea or prospect of moving to a different country is interpreted as a traumatic dilemma, a crisis, overcoming of which usually results in the decision to stay put (Tenderness, Everything I Like).

\section{Lightness of tourism with a touch of trauma}

This situation changes only at the turn of the millennium. Starting with Vadí nevadí (Truth or Dare, 2001) by Eva Borušovičová, the attitude to travelling and mobility frees itself from stories of hesitation, albeit not from the potential of trauma.

Truth or Dare continues in the almost forgotten direction of Štefan Semjan's debut On the Beautiful Blue Danube. Its characters are young bohemians living in loose, open relationships, but tied to the capital city and mostly its night life. Characters of Borušovičovás film are, nevertheless, constantly confronted with the topic of emigration or tourism. They share a flat with a couple of never-present globetrotters, or, as a part of film's crime plotline, make verbal jokes about running abroad from the law. ${ }^{11}$

11 This could be understood as a continuation of the socialistic paradigm, when the characters travelling abroad were often associated with crime or moral decline (as Petra 
This, however, also means that none of the characters depicted in the film really travels. During the first decade of the new millennium, the films by upcoming generation of female directors offer a symptomatic paradigm where desire to travel occurs more naturally than in films by 1990s' male debutants, but, on the other hand, travelling itself remains either imagined (as in Truth or Dare) or presented as a carefree whim inevitably followed by a harsh fall. In her second film Nebo, peklo ... zem (Heaven, Hell ... Earth, 2009), Laura Siváková for example tells the story of a ballet dancer who receives an offer to dance in one of the best ensembles in the world - but, shortly before making the trip, she breaks her leg and spends long months re-evaluating her past life and her attitude to men. The film itself is thus constructed as a narrative about a long process of reconciliation and self-reflection, and the scenes of heroine's leaving the country appear not earlier than in its finale.

A debut by another young female director Katarína Šulajová, $O$ dve slabiky pozadu (Two Syllables Behind, 2004), offers an autobiographically motivated main character (portrayed by the director's sister) hysterically fluctuating between middle-European past of her city and more globalised world she tries to integrate in. Her travelling to Paris for a weekend, which should signal a carefree lifestyle of the youth, becomes the beginning of a traumatic experience instead: confronted with disillusion in her Parisian love affair, the heroine blames her post-socialist identity as the basis of her uprootedness in the Western world.

What is common for all of the three films is that they are all made by young graduates of Dramaturgy and Scriptwriting from the Academy of Performing Arts in Bratislava (VŠMU). All of the mentioned films are also part of a trend branded by Slovak film critics as "urban lifestyle film," ${ }^{2}$ usually taking place in urban settings of country's capital and focusing on art students or the upper middle class often employed in show business, television or advertising industry. According to Martin Šmatlák, this type of film "does not attempt to portray either the contemporary or the historic social context"; at the same time, it is emphasising

Hanáková shows taking the example of Czech cinema, see Petra Hanáková, "Staying Home and Safe: Czech Cinema and the Refusal to be Transnational," in: European Cinema after the Wall: Screening East-West Mobility, eds. Leen Engelen and Kris van Heuckelom (Lanham: Rowman \& Littlefield, 2013), pp. 113-124).

12 This term was for the first time coined by Juraj Malíček in his review of Katarína Šulajovás debut film (Juraj Malíček, "Pop po domácky," Slovo, Vol. 7, No. 9 (2005), p. 16), and soon after re-used by several other authors, e.g. Martin Šmatlák, "Hladanie vlastnej cesty," Kino-Ikon, Vol. 12, No. 1 (2008), p. 135-147; Jana Dudková, Slovenský film v ére transkulturality (Bratislava: Drewo a srd - Vysoká škola múzických umení, 2011). 
"music-video-style" or visually segmented storytelling, as well as "several other external characteristics (emphasised by J.D.) of contemporary world, such as cars and drugs, businessmen and bars, ubiquitous telly, dubbing or intrusive adverts, well-known city figures, socialites, petty celebrities and local wannabes [...]."'13

Even if more conservative critics and historians like Šmatlák perceive the trend as detached from life and meaningless, the trend actually meant a progressive distancing from even more "detached" films of Martin Šulík and his epigones, usually taking place in isolated, heterotopic or idyllic places - gardens and countryside family residences.

In other words, the transition to urban lifestyle films was the result of the need to change the dominant paradigm of Slovak art-house cinema represented predominantly by early Martin Šulík's films and oriented more to the festival audiences and universal artistic values but ignoring "the pulse of the times." ${ }^{14}$

This can be interpreted as a generational gesture (since these films usually deal with generational dilemmas of young artists), as well as an attempt to transform the Slovak cinema in order to be more attractive to (young) domestic audience. That is why these films often resemble Czech commercially successful ones, ${ }^{15}$ even though their success with the audience was actually negligible. It is important to stress that the trend of "urban lifestyle film," which starts in 2001, with Eva Borušovičovás Truth or Dare and her classmate Vladimír Adásek’s Hana a jej bratia (Hannah and Her Brothers), did not become the domain of female directors, and not even of the new generation of debutants. Miroslav Šindelka, one of the debutants from the 1990s, made his second film in this fashion (Zostane to medzi name - It Will Stay Between Us, 2003) and even Miloslav Luther, who usually makes classical historical narratives, made his Tango s komármi (Mosquitoe's Tango, 2009) as an "urban lifestyle film."

The style, however, appeared during the continuing crisis of Slovak cinema when many young male directors ended up in advertising industry or television, and when more persistence in their film-making efforts was demonstrated by young female graduates. As I already pointed out, all of them were graduated scriptwriters, ${ }^{16}$ faced with the lack of potential directors who would share their sensibility or generational perspective, and finally encouraged by their teachers to

13 Šmatlák, "Hladanie vlastnej cesty," p. 145.

14 Malíček, "Pop po domácky."

15 For example, Truth or Dare shares similar motifs with David Ondříček's cult movie Samotári (Loners, 2000).

16 Eva Borušovičová is the only one to have graduated also in directing from the same school. 
direct their own scripts ${ }^{17}$ (in a similar fashion, yet another graduated scriptwriter, Zuzana Liová, became a pioneer of another genre - social drama).

What is, nevertheless, quite symptomatic here, is the fact that some of them, i.e. Eva Borušovičová and Laura Siváková, even debuted within the very paradigm of The Garden, ${ }^{18}$ using the element of an isolated family settlement as the dominant topos. ${ }^{19}$

Thus, the "urban lifestyle film" didn't appear as a radical opposition to cinema of the 1990s. In a way, behind it even stayed some of the most prominent creators of the 1990s' paradigm of "hanging gardens" ${ }^{20}$ : Peter Šulaj, one of the scriptwriters of The Garden, who is not only the father of the debuting Katarína Šulajová but, together with Martin Šulík, was also one of the most prominent teachers at the Academy of Performing Arts at the time when the mentioned generation studied there; or Rudolf Biermann, who appeared as the producer of Eva Borušovičovás and Laura Sivákovás debut films Blue Heaven and Quartétto, ${ }^{21}$ in response to which both female directors continued their careers in a different, "urban lifestyle" trend. The most prominent filmmakers of the 1990s not only shared their knowhow or co-workers with their students but also, indirectly, encouraged some major changes in Slovak cinema, ${ }^{22}$ including its metaphors and allusions representing the relation between the search for national identity and the opening to the world.

17 The only exception is once again Eva Borušovičová and her directorial debut whose script was written in collaboration with a young graduate from scriptwriting, Jana Skořepová, according to Skořepovás autobiographical master's script.

18 This is true namely for Borušovičovás debut Blue Heaven as a direct female reaction to The Garden, but also for Sivákovás Quartétto (2002) as an inter-generational family drama of a dying mother and her three daughters, who meet in an isolated family residence.

19 A similar topos is characteristic also for the post-November Czech cinema - emphasised e.g. by Jan Čulík, Jací jsme: Česká společnost v hraném filmu devadesátých a nultých let (Brno: Host, 2007).

20 The term was coined by Zuzana Tatárová in her review of Blue Heaven, as a reference to the ironic attitude of some critics to a trend fostered by Martin Šulík's early films. See Zuzana Tatárová, “Visuté záhrady Slovenska," Kino-Ikon, Vol. 2, No. 4 (1998), pp. 75-76.

21 Biermann produced Šulík's films for more than 10 years (starting already with Šulík's debut Tenderness, still within the frame of state-run cinema, and continuing as an independent producer). Besides this, he also produced some other debuts that followed Šulík's powerful garden metaphor, such as Miroslav Šindelka's 1994 Passionate Kiss, prepared and released in the time when Šulík already worked on The Garden.

22 Martin Šulík was considered even as the potential director of the television film Ticho (Silence, 2005) which eventually became the directorial debut of Zuzana Liová, and 
In contrast with debutants of the 1990s who question the sense of leaving the country, female debutants of the 2000s represent travelling abroad as a natural part of the new lifestyles. Unlike early films by Martin Šulík, millennial debuts and second films by young filmmakers also shift their focus more to young female or even transgender characters (e.g. the playfully semi-autobiographical character of a transgender singer Hannah played by the director himself in Vladimír Adásek's debut Hannah and Her Brothers). The decade of reconciling with societal changes influences also the works of older directors at least in the sense of accepting the international mobility as a basis of changing social environment with increasing presence of immigrants from various parts of the world (mostly the "third" one, though: e.g. in films such as Mosquitoe's Tango, Ženy môjho muža-My Husband's Women, 2009, dir. Ivan Vojnár, but also Two Syllables Behind).

On the other hand, the millennial debutants reproduce two important features that are characteristic also for the films of Sulík's generation: isolation of the cultural elite, and perception of the new travel opportunities as a test or even a trauma. In all of the "urban lifestyle films," there is a remarkable focus not only on artists, art students and creative industry workers, but also on the upper class or members of show business. Unlike the films of a bit older directors who also embraced this style, films by upcoming debutants such as Truth or Dare, Hannah and Her Brothers and Two Syllables Behind go beyond this attractive surface and suggest the intergenerational solidarity between artists, ${ }^{23}$ thus modifying the idea of intellectual as a gardener (whose role is to cultivate and protect the real humanistic values despite the disfavour of the political establishment) - and propose an idea of an isolated professional community instead.

together with his own Slnečný štát (The City of the Sun, 2005), the first Slovak contemporary social drama.

23 For example, the cast of Truth or Dare and Hannah and Her Brothers include numerous classmates or teachers of their authors from both Theatre and Film and Television Faculty of the Academy of Performing Arts in Bratislava, while, in its conclusion, Two Syllables Behind features one of the most respected authors of psychological drama in Slovak cinema between 1962 and 1989, the director Martin Hollý (1931-2004) in a cameo role of an empathetic dubbing director. The relationship between the film's heroine, a dubbing actress, and Martin Hollý refers to an unfulfilled need of debuting generations of film authors, a need to stay connected to or even taught by professionals of the previous era, since most of the older directors got completely lost after the collapse of post-1989 Slovak cinema, occasionally working in other spheres of the industry like in the aforementioned dubbing. 


\section{Every day in the lives of the uprooted ones}

Within less than a decade, the situation changes again, and - peculiarly enough again the change is mostly brought about by female directors and their films about young heroines in search of their place in the world. But instead of "urban lifestyle film," the new debuts place emphasis on "minimalistic" narration that fares better with international festival trends (abandoning thus the idea of focusing predominantly on domestic cinemagoers) and draw attention to the social, existential and economic aspects of migration: to issues of poverty, and conception of journeying as a metaphor of essential uprooting in contemporary world.

In 2009, Prague-based FAMU (Filmová a televizní fakulta Akademie múzických umění v Praze) graduate Mira Fornay makes the first "Slovak" debut ${ }^{24}$ to have made it into the official selection at a major film festival (namely, IFF Venice). Lištičky (Foxes) is also the first film that deals predominantly with the experiences of Slovak economic migrants. It tells the story of two sisters trying to integrate in Ireland: the older, Tina, is getting married to a successful Irish businessman while having also a love affair with a young Pakistani, and the younger, Betka, still tries to find her place while at the same time furiously refusing the sister's help. The film demonstrates not only solidarity among the uprooted ones, ${ }^{25}$ but also mutual exploitation between minorities (e.g. Betka becomes a throwaway toy in the hands of a "negro" businessman). Within Slovak cinema, Foxes is the first example of a film that thematises uprooting of Slovak economic émigrés, their feelings of frustration and tenacious efforts to be included into the new society.

In her cinematic debut Dom (The House, 2011), Zuzana Liová uses the topic of a generational conflict between the desire to support a family - literally to build a house for each child - and the desire of a young protagonist to move to England. The film ends with a hint at a reconciliation between a father and a daughter, opening up the possibility the daughter will finally manage to leave her birthplace. On the other hand, focusing on the desire of moving away - and not on the moving away itself - can be interpreted as a sign of a continuing paradigm, in which each journey is preceded by a long process of deliberation, long (and often hidden) preparations, and inter-generational negotiations.

Iveta Grófovás debut $A \check{z}$ do mesta Ař (Made in Ash, 2012), a combination of liveaction, documentary and animated film, returns to the topic of Slovak economic migrants living "west" of their homeland. It, however, does not offer a confrontation

24 In fact, it is a Czecho-Slovak-Irish co-production.

25 For example the relationship of a Slovak girl and a Pakistani, or the Polish-SlovakCzech attempts at establishing a contact. 
with the well-functioning, metropolitan world, as is the case in Foxes, but rather a continuous picture of social decline at a periphery, regardless of the point of reference. The main character Dorotka moves from a Romani settlement to a borderline Czech city of Aš (pronounced as "ash"). Despite of her Romani origin, here she becomes literally referred to as one of the many other "Slovak" girls and many more from the East (i.e. from former Soviet republics, or even Mongolia) who, after losing their poor jobs in the declining textile factories, end up in the hands of pimps or elderly German men looking for a second chance before their retirement.

Made in Ash suggests a meaning of the journey as an attempt to escape from a hopeless situation one couldn't change in his or her original environment. While Dorotka and other immigrants come to Aš looking for work, elderly German men criss-cross the streets in hope of meeting a girl not only for amusement but also in order to have someone to spend their approaching old age with. Instead of fulfilling their dreams, both groups experience rather various forms of displacement, losing the support of their languages, family ties or authentic feelings.

After Made in Ash, the topic of international mobility completely moves from "women's" hands and becomes the domain of male directors. A "scenario" from the turn of the millennium is being repeated where stories about women, written and directed by women, only helped to change the dominant paradigm of Slovak cinema - but their continuation was not so dependent on female authorship. What is interesting here, though, is the fact that male films dealing with journeying, mobility or migration are usually made by renowned directors. Despite of that, they still continue to refer to a "symbolic capital" of fiction debuts. In other words, the topic appears exclusively in the first fiction films by documentary directors.

Not all of these films offer the topic of international travelling, but most of them make use of topics of journeying and escape. Already the very first of these "debuts," Zázrak (Miracle, 2013) by Juraj Lehotský, brings the story of a girl running away from a detention centre. Maratón (Marathon), an episode from another live-action debut by documentary director, Deti (Children, 2014) by Jaro Vojtek, starts as an existential journey narrative and portrays an escape of a Romani prisoner through a snow-covered landscape, in order to embrace his wife and son once more. In both cases, the protagonists are eventually captured and returned to the disciplinary or correction institutions from which they had fled - while at the same time they discover that their dreams of love or family happiness have crumbled, their lovers or wives cheat on them and their children do not even recognise them. Thus, both films continue the paradigm of an existential scepticism typical for the first Slovak "social dramas." In both of them, trips are conceived as possible and even liberating, yet both remain sceptical about the possibility of improvement or happiness as the final goal of moving. 
A small step apart from this scepticism appears only in 2015, when the first two Slovak variations on the road movie were made. The first one is Koza, a fiction debut by yet another documentary director Ivan Ostrochovský, a fusion of road movie and social drama about the unsuccessful tour of a former Olympic boxer (today an outcast living in a Romani settlement). The second one is a directorial debut by scriptwriter Rastislav Boroš Stanko, telling the story of a petty criminal returning to Slovakia with a task to bring along pretty local girls for his Italian Mafioso boss. As a permanent loser, he manages to get only a naive Gypsy girl who believes he will take her to her mother in France.

The journeying theme is also key for another 2015 live-action debut by a documentarian, Eva Nová by Marko Škop. In this film, the main protagonist obstinately shuffles between her tediously empty flat in the capital and a family house somewhere in eastern Slovakia in a desperate attempt to reunite with her son, whom she had abandoned years ago. Images of the protagonist in an old-fashioned dress, repeatedly pulling her wheeled suitcase, refer to the burden of the past she carries with her, preventing her from starting anew. Similarly, like Foxes, Eva Nová introduces the motive of work-related migration. However, instead of the topic of uprootedness in the foreign world, it focuses on the issue of leaving the nest and the decay of family ties.

Instead of a sceptical approach repeated in multiple variations throughout the whole history of Slovak post-socialist cinema, both Eva Nová and Koza choose a parable of journey as a calvary. Koza literally "creates a parallel between Christ's calvary and the last tour of a former Olympic champion" ${ }^{26}$ by using several visual references to the biblical story: before departing to his tour, Koza rests with his girlfriend creating a visual paraphrase of Michelangelo's Pietà; while training, he drags a wheel resembling Christ carrying his cross etc. ${ }^{27}$ Similar visual parallels can be found in the trope of dragging a suitcase (= the burden of the past) along in Eva Nová.

While in the social dramas from previous period (Made in Ash, Miracle, Children etc.), the journey was still perceived as an unsuccessful (or traumatic Foxes) escape, with the exception of Zuzana Liovás The House, which refers to an even older paradigm of conceiving the journey only as a dream or desire (and not reality), films released in 2015 also break through the sceptical attitude towards the

26 Katarína Mišíková “The Real Story: Indexing Strategies of Slovak Social Film Dramas,” in: Transformation Processes in Post-Socialist Screen Media, eds. Jana Dudková and Katarína Mišíková (Bratislava: Vysoká škola múzických umení v Bratislave - Ústav divadelnej vedy SAV, 2016a), pp. 60-76.

27 See also Katarína Mišíková “Žánrové križovatky a rekordy slovenského hraného filmu roku 2015," Kino-Ikon, Vol. 20, No. 2 (2016b), p. 97. 
possibility of change and a proactive attitude on the part of their protagonists. All of them are possible to be understood also as stories about revealing of empathy: the Romani girl in Stanko, boxer Koza and the former actress and alcoholic Eva Nová are all Christ-like figures who - through their own suffering - bring empathy to the world. During his journey, the main character of Koza changes the cynical nature of his manager, the Romany girl alters the character of the petty criminal Stanko, and, in the end, Eva Nová cracks the rejecting mask of her son.

Strangely enough, this transformation of the typical paradigm could be perceived exactly through the lenses of a traditional dichotomy between male rationality and female emotionality. Starting with Eva Borušovičovás debut Blue Heaven, Slovak producers continued to invest in female debutants perspective, which, in the end and often in contrast with their original intentions, resulted in overcoming the limits of metaphorical male gardens. But - not surprisingly all of the crucial and most inspiring transformations of dominant paradigms were actually brought about by abandoning the father/teacher patterns as well as the stereotypical division into "male" and "female." After 2009, the journey finally starts to be associated with crossing the boundaries, not only those between nations and cultures, but eventually also those between human beings. What is also interesting here is the fact that the latter tendency was preferred more by men even though it had been provoked by female debutants and their harsh scepticism. So, while "urban lifestyle films" often refer to the aesthetics of "coolness," ${ }^{28}$ and first "social dramas" by female directors are sceptical depictions of cruel, emotionless world (unlike the much more sentimental attempts on the genre by Martin Šulík, i.e. his Cigán - Gypsy, 2011), only a new type of debuts - fiction debuts by already renowned documentarians such as the aforementioned Children, Eva Nová, Miracle or Koza - bring these two polarities together.

\section{Bibliography}

Čulík, Jan. Jací jsme: Česká společnost v hraném filmu devadesátých a nultých let. Brno: Host, 2007.

Dudková, Jana. Slovenský film v ére transkulturality. Bratislava: Drewo a srd Vysoká škola múzických umení, 2011.

28 See, e.g. the title of Martin Šmatlák's review of It Will Stay Between Us (Martin Šmatlák, "Cool XXL," Domino fórum, Vol. 12, No. 42 (2003), p. 26); for more about the domestic perception of "urban lifestyle films" within the intuitive frame of the aesthetics of coolness, see Jana Dudková, Slovenský film $v$ ére transkulturality (Bratislava: Drewo a srd - VŠMU, 2011), pp. 75-76. 
Dudková, Jana. "Between the Center and the Margin: The Notion of Central Europe in Slovak Cinema After 1989." Iluminace, Vol. 25, No. 4, 2013, pp. 7-94. Gindl-Tatárová, Zuzana. “The Garden.” In: The Cinema of Central Europe, ed. Peter Hames. London, New York: Wallflower Press, 2004, pp. 245-253.

Hanáková, Petra. "Staying Home and Safe: Czech Cinema and the Refusal to be Transnational." In: European Cinema after the Wall: Screening East-West Mobility, eds. Leen Engelen and Kris van Heuckelom. Lanham: Rowman \& Littlefield, 2013, pp. 113-124.

Iordanova, Dina. Cinema of Flames. Balkan Film, Culture and the Media. London: British Film Institute, 2001.

Krekovič, Miloš. “Stratená generácia?” SME, 4 March 2010. https://kultura.sme. sk/c/5264969/stratena-generacia.html\#axzz4mXXL3U9j (11 July 2017).

Krekovič, Miloš. "Ako vzniká hit: Na krásnom modrom Dunaji." SME, 12 April 2012. https://kultura.sme.sk/c/6333328/ako-vznika-hit-na-krasnom-modromdunaji.html\#axzz4m5AGELA6 (11 July 2017).

Macek, Václav. “1 297254000 Sk.” Kino-Ikon, Vol. 14, No. 1, 2010, pp. 125-154.

Malíček, Juraj. “Pop po domácky.” Slovo, Vol. 7, No. 9, 2005, p. 16.

Mišíková, Katarína. “The Real Story: Indexing Strategies of Slovak Social Film Dramas." In: Transformation Processes in Post-Socialist Screen Media, eds. Jana Dudková and Katarína Mišíková. Bratislava: Vysoká škola múzických umení v Bratislave - Ústav divadelnej vedy SAV, 2016a, pp. 60-76.

Mišíková, Katarína. "Žánrové križovatky a rekordy slovenského hraného filmu roku 2015." Kino-Ikon, Vol. 20, No. 2, 2016b, pp. 85-99.

Šmatlák, Martin. “Cool XXL.” Domino fórum, Vol. 12, No. 42, 2003, p. 26.

Šmatlák, Martin. "Hladanie vlastnej cesty." Kino-Ikon, Vol. 12, No. 1, 2008, pp. 135-147.

Šmatlák, Martin. "Dlhý čas ožívania. Dvadsat rokov na ceste k odštátneniu slovenskej kinematografie." Kino-Ikon, Vol. 20, No. 2, 2016a, pp. 5-50.

Šmatlák, Martin. "Slovak Audiovisual Fund - A Brief History of Prolonged Time." In: Transformation Processes in Post-Socialist Screen Media, eds. Jana Dudková and Katarína Mišíková. Bratislava: Vysoká škola múzických umení v Bratislave Ústav divadelnej vedy SAV, 2016b, pp. 11-20.

Tatárová, Zuzana. "Visuté záhrady Slovenska." Kino-Ikon, Vol. 2, No. 4, 1998, pp. 75-76.

Zuska, Vlastimil. “Topos zahrady v Zahradě a jeho časoznakové implikace.” In: Svet v pohyblivých obrazoch Martina Šulika, ed. Marián Brázda. Bratislava: Slovenský filmový ústav, 2000, pp. 122-147. 


\title{
Katarína Mišíková \\ Academy of Perfoming Arts in Bratislava, Slovakia \\ 8. Reality of corporeality: Female corporeality in recent Slovak social film dramas
}

\begin{abstract}
The most distinctive cinematic trend of contemporary Slovak cinema, labeled as social drama, is characterized by current topics, such as racism, relationship between majority and minority, disintegration of family relations, changes in the ethical values of a society undergoing constant economical transformations, prostitution, unemployment, and poverty. Although it is a stylistically rather heterogeneous body of films, it can be described by a prominent realistic tendency. Several of these films are fiction debuts of documentary filmmakers who draw heavily from non-fiction and observational realism conventions, one of these being the portrayal of physical experience. My chapter deals with specific ways the experience of female corporeality in crisis as presented by accentuating the relationship between the physical and the social body. It examines depictions of various physical and social aspects of processes that female characters of recent Slovak social dramas are subject to, such as adolescence, aging, pregnancy and motherhood, physical (self-)abuse, and violence.
\end{abstract}

Keywords: Slovak cinema, corporeality, realism, female characters

Democratic processes of the 1990s in East-Central Europe and following European integration introduced several new topics into Slovak cinema. One of them was reconsideration of traditional female archetypes and stereotypes in the light of gender studies. In times when turbulent transition to market economy lured away many talented filmmakers among male providers into commercial sphere, a significant trend of female scriptwriters and directors came to the forefront. Eva Filová in her "gender history" of Slovak cinema Eros, sexus, gender in Slovak Cinema divides the work of female authors who emerged at the turn of the millennium - Eva Borušovičovás Blue Heaven (Modré z neba, 1997) and Truth or Dare (Vadí nevadí, 2001); Laura Sivákovás Quartétto (2002) and Heaven, Hell... Earth (Nebo, peklo... zem, 2009); Katarína Šulajovás Two Syllables Behind (O dve slabiky pozadu, 2004); Zuzana Liovás Silence (Ticho, 2005) ${ }^{1}$ and The House (Dom, 2011); and Mira Fornay’s² Foxes (Lištičky, 2009) - into three groups: “1) lifestyle stories

1 Liová made her feature-length debut as a TV film produced by the Slovak Television.

2 Although of Slovak origin, Fornay is the only one among mentioned female directors who did not graduate from scriptwriting at the Film and Television Faculty at the 
about independent young women, 2) stories of female genealogy, stigmatised by motherhood, 3) stories of bad girls - revolting nature of feminist." ${ }^{3}$ Filová explores how this "feminization" of Slovak cinema reflected current feminist trends and brought about new types of heroines, who in various degrees and ways questioned the role of woman-body and woman-mother, and sought to introduce woman subject into Slovak cinema.

My chapter deals in somewhat more modest and less political way with different aspects of female heroines in contemporary Slovak cinema, which concern 1) the relationship between the social and physical female body and 2) the ways of realistic depiction of socially determined emotional and physical states and sensation of female characters by means of poetic tropes. The changed social situation of women in contemporary Slovak cinema is, on the one hand, connected to gradual (however, still somehow gentle) sensitization to gender issues, and, on the other hand, to new economic opportunities of Slovak citizens in the European Union. A traditional role of a woman, tied to land and family, ${ }^{4}$ is thus changing and we can witness a growing number of migrating women characters. However, this new female mobility does not only bring positive values in the form of social or economic capital, it is often accompanied by social and physical degradation or destruction of heroines.

The films I am going to analyze are part of the social film drama trend that is currently the most consistent trend of Slovak art-house cinema. Social dramas are not the kinds of films, whose domain is female imagination; they do not primarily concern relationships between women and men or issues of female identity. They are rather concerned with reflection on current phenomena of post-socialist reality: disintegration of traditional family relations, economic migration, socially underprivileged groups, racial intolerance, etc. Therefore, we can hardly describe social drama as a feminist film trend - neither from the aspect of frequent character types nor from the aspect of authorial background. Only three women are active among social drama directors (Mira Fornay, Zuzana Liová, and Iveta Grófová), and although the main characters of their films are usually women (with the exception of My Dog Killer [Môj pes Killer, 2013] by Mira Fornay),

Academy of Performing Arts in Bratislava, but studied film directing at the Film and TV School of the Academy of Performing Arts in Prague.

3 Eva Filová, Eros, sexus, gender v slovenskom filme (Bratislava: Slovenský filmový ústav, 2013), p. 199.

4 The female archetype of a woman grounded in and tied to an enclosed rural residence is prominent in films such as The Garden (Záhrada, 1995) by Martin Šulík or Blue Heaven by Eva Borušovičová. 
the reflection on female fate is not their central subject. However, I will claim, that what these films have in common, is a transformational crisis of female characters. Each of them undergoes a series of social and physical transformations, which are an important part of the realistic representation of the actual reality. This distinguishes them from all three groups of female films from the millennial turn as identified by Filová. Those connected female view of reality mainly with the sphere of imagination and dreams and in this way separated it from the public sphere and hence current social situation. ${ }^{5}$ Nevertheless, not all analyzed films are stories of bad girls, rather they propose an interpretation of social reality by means of current subject matter and realistically motivated poetic tropes.

\section{Realism and corporeality}

Current social issues are a common thematic motif of realist cinema ${ }^{6}$; however, realism is not easily defined by a certain group of narrative and stylistic devices. Techniques of evoking the reality effect can vary from hand-held camera to extreme long shots, from featuring amateur actors to professionals, and from long shots to jump cuts. ${ }^{7}$ A recurring technique of the realist style is the portrayal of emotional states of characters as physical states. Let us consider two examples in which long shot as a seemingly unmanipulated representation of reality evokes an impression of reality. Film Koza (2015) by Ivan Ostrochovský about the last tour of a former boxing champion is shot predominantly in static long shots that cue the viewer to take part in physical suffering of the main character. When portraying the physical suffering of the boxer during and after his fights, the camera dwells on the image of the boxer scapegoat, ${ }^{8}$ thus cueing the viewer to take part in the protagonist's martyrdom. Similar device is used in the film Made in Ash ( $A z z$ do mesta $A \check{s}, 2012$ ) by Iveta Grófová, when the viewer is indirectly witnessing a real piercing of heroine's lower lip and almost perceives her pain from the needle

5 See Filová, Eros, p. 206.

6 Kristin Thompson, "Realism in Cinema: Bicycle Thieves," in: Breaking the Glass Armour. Neoformalist Film Analysis (Princeton: Princeton University Press, 1988), pp. 197-217.

7 For detailed narrative and stylistic analysis of the social film drama trend, see Katarína Mišíková, "Hladanie žánru v súčasnom slovenskom hranom filme," in: Nový slovenský film. Produkčné, estetické, distribučné a kritické východiská, eds. Katarína Mišíková and Mária Ferenčuhová (Bratislava: Vysoká škola múzických umení, Filmová a televízna fakulta, 2015), pp. 9-36.

8 "Koza" means "goat" in Slovak. It is the nickname of the real-life Roma protagonist of this film, former Olympic boxing champion Peter Baláž. 
in the lip in a literary way. These devices emphasize the ontology of cinematic image as an actual image of pro-filmic reality by evoking visceral experiences of characters. Social drama films featuring female characters can provide even more complex instances of demonstrating the relationship between the social and the physical body of protagonists, because they depict emotional and psychological transformations of characters as physical states.

\section{Transformational crisis of female characters in social dramas}

The analyzed body of films presents various types of migrating women, who are forced by their social situation to move from one place to another, and in this process, undergo also complex physical and psychological transformations. Their horizontal movement is motivated by problematic family and economic background. Similar to men, they are looking for job opportunities in more prosperous regions of Europe, where they assume economic responsibility of themselves in typical female occupations as caretakers. Betka, the protagonist of film Foxes by Mira Fornay, left her provincial birthplace because of the lack of job opportunities and followed her elder sister to Ireland in order to work as an au pair. Similarly, in the film Eva Nová (2015) by Marko Škop the daughter-in-law of the main character leaves her drunkard husband and moves to Austria, where she works as a home nurse. Dorotka, the heroine of Made in Ash, was a good student, but straight after her A-levels she is forced by the social situation of her family living in Romani settlement in Eastern Slovakia to leave for the Czech town of Aš and together with other Eastern European and Asian girls to work as a seamstress in a textile factory. Other characters are forced to leave their homes because of broken family ties or because of problems with alcohol and drugs. A restless adolescent Ela from the film Miracle (Zázrak, 2013) by Juraj Lehotský was sent to the detention center by her mother, who lives with a younger boyfriend. From there, Ela flees to her drug-addicted boyfriend, who sells her as a white slave to gangsters, and after her escape she finds - at least temporarily - peace at the institution for pregnant adolescents. An aging former actress Eva Nová from the eponymous film is leaving the alcoholic rehab for the third time, she goes from one inferior job to another, and in a quest for a renewal of the relationship to her estranged son, she repeatedly travels from the city to her birthplace in rural Slovakia. Eva, heroine from The House, is trying to get away from her native home in a small town and from her authoritative father in order to study and work in England.

These female characters are moving not only horizontally but also climb or fall in the social hierarchy. Eva Nová used to be a prominent actress of the socialist era, but after the break-up with her partner and director and after the change of 
regime, she fell under the spell of alcohol, which got her to her knees. She has no ambition to get back into the spotlight; she just wants to defend her right to get a second chance, mainly in relation with her son, whom she neglected in her heyday. Inadaptable and aggressive Betka from Foxes becomes a second-rate citizen in Ireland, one of many Eastern European girls, who might be useful for work and fun, but are not suitable for the acceptance in society. Heroines of films Made in Ash and Miracle reach the very bottom of social hierarchy. Dorotka from Made in Ash loses her job at the factory and struggles along in bars until her more experienced friend finds a German sex tourist for her. Ela from Miracle wants to save her boyfriend from debts and agrees to be sold to gangsters as a prostitute; they rape and beat her and only after her escape she finds out that her boyfriend actually does not care for her at all. Relatively secure is the social situation of Eva from The House; however, she manages to fly away from the family nest in the end and has to look for her own place in the world.

As we can see, these are stories of socially motivated migrations, the ups and downs of heroines. All of them are stories of transformational crisis, in which the social and physical frames of migrating women change: they undergo the process of coming of age, aging, pregnancy and motherhood, physical abuse, and violence. In order to emphasize the psychological aspects of these physical transformations, the films deploy a wide array of stylistic devices, from observational realism to complex poetic figures. According to the conceptual metaphor theory by George Lakoff and Mark Johnson as proposed in their Metaphors We Live By, ${ }^{9}$ poetic tropes provide abstract concepts with factual reality and give symbolic structure to material reality. In these films, the metaphorical images are not only organically integrated into a realistic discourse, but they are also directly connected to the physical and emotional states of the protagonists. In this way, they support Lakoff and Johnson's claims that metaphors enable us to comprehend human experience by means of metaphorical projection, in which we grasp abstract concepts using the concepts that stem from a physical base.

The social film drama trend in Slovak cinema typically concentrates on subjects such as economic transformation of post-socialist reality, multiculturalism, globalization, and disadvantaged social groups. These subjects are predominantly portrayed through stories of decaying family relations: female protagonists lose their safe domestic harbor and have to face their crisis alone. While all these themes of female transformations deal with the impact of crisis on protagonists'

9 George Lakoff and Mark Johnson, Metaphors We Live By (Chicago: University of Chicago Press, 1980). 
psychological and social status, they are rendered through a series of embodied metaphors. The theme of coming of age corresponds to tropes associated with the dialectics of freedom and stability; the theme of violence and (self)abuse is evoked by tropes of victims; the theme of aging is emphasized by images of physical decay of objects; and the theme of motherhood makes use of aquatic metaphors, evoking images of amniotic fluid.

\section{Coming of age}

In the fragile phase of adolescence, the heroines negotiate between the need to be independent and the need to feel safe. Their process of coming of age is marked by conflicts with parents who are reluctant to respect this dialectic.

In The House, high school student Eva takes cleaning jobs in order to save enough money for her ticket to England, and she spends all her free time helping her father to construct a house she has no intention to live in. She experiences a brief, but intense love affair with her teacher, and in the end, is able to set herself free from her birthplace and leave for England. The figure of windows cleaning points to Eva's need to broaden her horizons, to see the world with her own eyes. The house in the process of construction is both a complex metonymy and a metaphor. It is a metonymy of a family that suffers from the lack of affection by the father who tries to secure only material needs of his daughter. It is also a metaphor of Slovakia - a country still "under construction." Finally, the rural residence metaphorically points to the tradition that restrains the character instead of providing her with safety.

The heroine of film Miracle experiences a drastically accelerated process of coming of age, when she is separated from her family and soon loses also her somewhat childish ideas about romantic relationships. Ela is still a child and she longs for someone who is going to take care of her. Before she leaves with the gangsters, she asks her boyfriend to teach her to swim, which is something that children are usually taught by their parents. The figure of swimming is an embodied metaphor that describes Ela's situation: she wants somebody to teach her to swim in the deep waters of life, but people on whom she relies only let her drown.

\section{Violence/(self-)abuse}

Prostitution as the ultimate survival strategy of women living on the edge is a recurrent social drama motif; however, it is not the only way in which female bodies are subjected to oppression. Excluded from safe family relations, the disillusioned heroines often undergo the process of self-abuse in an elusive hope for better lives. 
In Foxes, the protagonist Betka is always getting into conflicts with other people. She is visually compared to stray foxes that wander around the streets of Dublin in search for something to eat and spread dangerous disease. Betka is handled by other people as a stray fox, they rarely miss an opportunity to show her their social dominance: may it be the family she works for, her new boss, or a lover. In a series of violent confrontations, she gradually loses everything and self-destructively tries to defend herself by destroying her sister, the only person who always helped her.

In Miracle, Ela experiences a common training of future prostitutes by a couple of gangsters, who test new material themselves before selling it. Her boyfriend drives her to his drug dealer, who traps Ela in a somber apartment, where she is forced to get naked in front of three gangsters, is raped by them, and on the way to another country manages to escape from the car and flee back to her lover.

In Made in Ash, Iveta Grófová has combined a documentary footage, shots from security cameras and mobiles phones with staged para documentary scenes, subjective defocused shots, and dream-like animation sequences in order to create a richly structured record of her protagonist's emotions and sensations. In intimate sex scenes, blurred images simulate subjective perceptions of physical trauma. An embodied metaphor of a stripper, "crucified" to a pole, is a representation of many girls, who on the symbolical end of post-socialist world become cheap entertainment for Western sex tourists.

\section{Aging}

While coming of age is an accelerated process of making a place for oneself in the world, aging is a gradual process of becoming irrelevant, almost invisible. Women stripped of their physical attractiveness lose their social roles outside of motherhood.

All analyzed films present young protagonists, the only exception being Eva Nová, where the heroine observes her process of aging. The story of once famous actress, who got old and weary in the struggle with alcoholism, and after years spent in rehab, tries to re-establish both her life and relationship with her estranged son, represents her crisis by several embodied metaphors. Škop develops the psychology of her character by recurrent portraits of her face that is constantly confronted with other people, her own reflection in mirrors, and old photographs from her past. Her fate is also embedded in her name: Eva Nová, New Eve. She is already old, but wants to make a new woman of herself. Eva carries the burden of the past, which the narration reveals very sparingly. The carry-on, which she takes with her on several occasions, is a metaphor of this burden. She is well aware 
of the fact that she is old and useless just like spoilt fruit she sorts in her new job in a supermarket, but she still tries to carry on with her life and therefore plants new flowers in her flat in place of those that dried completely during her absence.

\section{Motherhood}

Given that the majority of Slovak social film dramas are portrayals of dysfunctional and disintegrated families, one of the recurrent motifs is traumatized motherhood. Only toward the end of Foxes, a flashback reveals the true reason for Betka's hysterical behavior: she accidentally gets pregnant by her future brother-in-law and tries to get rid of the baby with a pair of scissors.

In Miracle, the underaged Ela is pregnant and decides to give birth to the unwanted child even though her mother warns her of spoiling her life in exactly the same way as she once did. In the end, Ela gives the baby for adoption. The last shot of the film shows Ela looking at the newborn baby that already does not belong to her. Tenderness on her face is a miracle, to which the film's title refers, as she never got any tenderness from anybody.

The most complex portrayal of traumatized motherhood represents Eva Nová. Because of her acting career she left her son in the care of her single sister. When she tries to become close with him after years, he refuses her. The film's closing is both a symbolic fight and an embrace of the mother with her son in an inflatable swimming pool. Its circular shape refers to their disintegrated family. The son bought the swimming pool for his wife, who has left him and has a swimming pool in her new Austrian home. This swimming pool is much larger; however, there is no water in it. The water in the inflatable swimming pool metaphorically refers to oblivion that both mother and son searched in alcoholism. In connection to the relationship between the mother and her son, the circular swimming pool also evokes mother's womb with amniotic fluid, in which their bond - at least temporarily - is reborn.

\section{Conclusion}

We can conclude that even though gender and feminist issues are not prominent in the social drama trend, these films present complex portrayals of several gender issues by emphasizing the relation between the physical and social bodies of female characters. Contrary to the feminine trend from the millennial turn, they do not reserve these subjects to the sphere of imagination, but make them a part of realistic representation of actual reality. Even though the stylistics of the films is predominantly realistic, these films do not stay away from poetic tropes, but 
deploy mainly figures that have an embodied quality to them and evoke emotional states of protagonists through the portrayal of physical processes and sensations.

This work was supported by the Slovak Research and Development Agency under the contract no. APVV-0797-12.

\section{Bibliography}

Filová, Eva. Eros, sexus, gender v slovenskom filme. Bratislava: Slovenský filmový ústav, 2013.

Lakoff, George and Johnson, Mark. Metaphors We Live By. Chicago: University of Chicago Press, 1980.

Mišíková, Katarína and Ferenčuhová, Mária, eds. Nový slovenský film. Produkčné, estetické, distribučné a kritické východiská. Bratislava: Vysoká škola múzických umení Bratislava, Filmová a televízna fakulta, 2015.

Thompson, Kristin. Breaking the Glass Armour. Neoformalist Film Analysis. Princeton: Princeton University Press, 1988. 



\title{
Sebastian Jagielski
}

Instytut Sztuk Audiowizualnych, Uniwersytet Jagielloński, Poland

\section{Before coming out: Queer representations in contemporary Polish cinema}

\begin{abstract}
In 2013, Polish cinema - owing to two popular films: In the Name Of... by Małgorzata Szumowska and Floating Skyscrapers by Tomasz Wasilewski - came out of the closet, which does not mean that queer issues had hitherto been absent in Polish cinema. The subject of this chapter will be the representations of non-normative men placed within the socio-cultural context of the latest Polish mainstream cinema. First, we will concentrate on popular romantic comedies that attempt to carry out affirmative politics. Next, let us look in detail, at the film Suicide Room (2011) by Jan Komasa, a film that directly preceded the premiere of Szumowska's and Wasilewski's movies, which clearly oversteps such identity politics, rejecting the stable and irrefutable identity for liquid identity, which does not come down to a choice between hetero- and homosexuality, but attempts to extract the plurality of its kinds.
\end{abstract}

Keywords: Polish cinema, queer cinema, queer representations, homosexuality, Suicide Room

In 2013, Polish cinema - owing to two popular films: In the Name Of... (W imię...) by Małgorzata Szumowska and Floating Skyscrapers (Płynace wieżowce) by Tomasz Wasilewski - came out of the closet $^{1}$, which does not mean that queer issues had hitherto been absent in Polish cinema. It is worth taking into consideration what preceded such a coming out. The subject of our interest will be the representations of non-normative men placed within the socio-cultural context of the latest Polish mainstream cinema. First, we will concentrate on popular romantic comedies that attempt to carry out - via images of white, asexual and monogamous, well-situated middle class gays - affirmative politics, based on the assumption that the more homosexuals resemble heterosexuals, the easier it will be for society to accept them. Let us look in detail, however, at the film Suicide Room (Sala samobójców, 2011) by Jan Komasa, a film that directly preceded the premiere of Szumowska's and Wasilewski's movies, which clearly oversteps such identity politics, rejecting

1 Michael Brooke, “Poland's coming out." Sight and Sound (2014): 1 Feb. 2017 http:// www.bfi.org.uk/news-opinion/sight-sound-magazine/features/poland-s-coming-out. 
the stable and irrefutable identity for liquid identity, which does not come down to a choice between hetero- and homosexuality, but attempts to extract the plurality of its hues. The rejection by the Polish directors of stereotypical, domesticated, bourgeois images of gays in exchange for representations glorifying the diversity and plurality of sexuality has meant that critics - as I will attempt to demonstrate have begun to manipulate the subversive potential contained in the texts, to conceal their true content so as to reclaim these films for the wider audience, simultaneously gaining power over them in order to support, and not destabilise, the dominant order.

\section{Towards emancipation}

After 1989, Polish gays and lesbians come out of the closet. Their disclosure, initially timid, over time more and more daring and liberating, is the consequence of the political system transformation. In communist Poland, the issue of homosexuality was devoid of its representation in the public discourse and, without any representation, it did not actually exist in the collective awareness. In the West, we witnessed a linear emancipative narration that led from the essentialist homogeneous movement of the 1950s through the gay-lesbian movement of the 1970s to the constructivist queer theory in the 1990s and 2000s. It was unlike in Poland where "the communist past created different social structures and modalities. Visually, this [the functioning of homosexuals in Poland and in the West - SJ] can be presented as two separated geopolitical and temporal modalities/temporalities/ time-images that function in a somehow parallel manner; and when one of them ends in 1989 the other one begins to be universal"2. Admittedly, the history of emancipation of lesbians and gays in Poland dates back to the 1980s but it was the early 1990s that brought some liberated animation along with the abolition of censorship. It did not last long, however, because the 1990s "saw the return of the worst kind of nationalistic and religious traditionalism"3, and capitalist

2 Joanna Mizielińska, „Idee pogubione w czasie - polityka LGBT vs teoria queer w Polsce i na Zachodzie" [Ideas Lost in Time: LGBT Politics vs. Queer Theory and Practice in Poland and in the 'West'], Przegląd Kulturoznawczy, Vol. 13, No. 3 (2012), p. 289. See also: De-Centring Western Sexualities: Central and Eastern European Perspectives, ed. Robert Kulpa and Joanna Mizielińska (Surrey: Ashgate, 2011); Łukasz Szulc, "Queer in Poland: Under Construction”, in: Queer in Europe: Contemporary Case Studies, ed. Lisa Downing, Rober Gillett (Surrey: Ashgate, 2011), pp. 159-172.

3 Paweł Leszkowicz and Tomek Kitliński, Miłość i demokracja. Rozważania o kwestii homoseksualnej $w$ Polsce [Love and democracy. Reflections on the homosexual question in Poland] (Kraków: Aureus, 2005), pp. 55-56. 
Poland turned out to be exclusively male and heterosexual. The second wave of emancipation dates to the turn of the twentieth and twenty-first centuries ${ }^{4}$ when the lesbian-gay organisation Kampania Przeciw Homofobii (Campaign Against Homophobia) is established and the first pride parade, called Parada Równości (Equality Parade) takes place, and the first draft law on homo- and heterosexual partnerships is prepared. However, it was first in 2003 that the lesbian-gay issue got into the public discourse with the symbolic collective coming out - the social campaign Let Them See Us (Niech nas zobacza) (the slogan itself conveys well the lack of visibility of gays and lesbians in the public space), which consisted of an exhibition of photographs by Karolina Breguła depicting 30 lesbian and gay couples holding each other's hands. The exhibition was intended to be first shown at a gallery and then on billboards in the larger cities of Poland. But following a smear campaign in the press and homophobic attacks by right-wing politicians, who did not perceive the action as promotion of tolerance and equality but as the promotion of homosexuality, galleries withdrew from earlier agreements and the billboards were devastated. Kitliński and Leszkowicz, who took part in the campaign by appearing in one of the photographs, remark, "The photographs displayed that which people were unable to talk about, which was outside the boundaries of the official language and image. (...) The portraits restore visibility to the invisible citizens and fill the ideological schemes with real people"5.

We witnessed absolute anti-homosexual panic, the escalation of violence and the language of hatred along with the subsequent Tolerance/Equality Marches that took place - or were illegally banned by city mayors - in Cracow, Warsaw or Poznan. A particularly animated media coverage illustrated the famous 2004 Tolerance March in Cracow supported by the Nobel Prize winners Czesław Miłosz and Wisława Szymborska, during which the participants were attacked outside the Wawel Castle and in the Cracow Main Square by right-wing militants, and the Church called the peaceful march a "provocation". Politicians noticed that they could gain political capital on homophobic slogans and they were not going to give

4 Zbyszek Sypniewski and Błażej Warkocki, „Wstęp“ [Introduction], in: Homofobia po polsku [Homophobia the Polish way], ed. Zbyszek Sypniewski and Błażej Warkocki (Warszawa: Sic!, 2004), p. 8. "The basic difference between the first and the second wave is the fact that the latter managed to penetrate the public discourse, and not necessarily as an exciting curiosity at that but as political and legal demands".

5 Paweł Leszkowicz and Tomek Kitliński, Miłość i demokracja, p. 20.

6 Cf. Błażej Warkocki, „Biedni Polacy patrzą na homoseksualistów“ [Poor Poles watch homosexuals], in: Homofobia po polsku [Homophobia the Polish way], ed. Zbyszek Sypniewski and Błażej Warkocki (Warszawa: Sic!, 2004), pp. 151-169. 
it up. Especially after 2005, the gay - who according to the right-wing discourse came to Poland from the West and thus was alien to the essence of the Polish national identity - was perceived in the public debate as a national enemy ${ }^{7}$. Right-wing politicians' anti-homosexual actions (the banning of the 2004 Warsaw Equality Parade by Lech Kaczyński, homophobic activity of the then Minister of Education Roman Giertych as well as of other Liga Polskich Rodzin [League of Polish Families] and Law and Justice politicians), attacks by right-wing militants during the peaceful marches (both literal and symbolic, to mention the telling shouts, "We'll do to you what Hitler did to the Jews", "Gas the faggots!", "Lesbians to labour camps!"8) and - a bit later (2012-2015) - seven arson attacks on the Rainbow (Tęcza) artistic construction by Julita Wójcik located in the Saviour Square in Warsaw and symbolising equality of rights of the LGBTQ (lesbian, gay, bisexual, transgender, queer) community, caused that the postulates of the sexual minorities gained allies among the defenders of the broadly understood freedom. Thus, lesbians and gays found themselves in a better social and legal situation than in the early 2000s. They appeared in the social awareness, for which much credit has to be given to the media, above all. The media provided wide coverage of not only the Tolerance/Equality Marches but also the phenomenon of the Polish gay literature (Michał Witkowski, Bartosz Żurawiecki, Marcin Szczygielski) or the high-profile coming-outs of some public persons (Krystian Lupa, Maria Janion, Michał Głowiński). Thereby, after 1989 in Poland, we experience the resignation from hiding, which was characteristic of the communist period, influenced not only by communism but also by Catholicism, for the benefit of overt confrontation and battle of the LGBTQ community for their rights. It seems that only visibility, social activism and defiance - both in the West as well as in Poland - can push forward the emancipatory endeavours of sexual minorities.

7 Agnieszka Graff, Rykoszetem. Rzecz o płci, seksualności i narodzie [By a Ricochet. On gender, sexuality and nation] (Warszawa: W.A.B., 2008), pp. 33-68.

8 Agnieszka Graff, Rykoszetem, p. 113. Graff analyses the collocation "gay i.e. Jew" as a code of vernacular culture, a mental shortcut that breeds aggression: "Judaisation of the enemy provides a handy tool because it actuates loads of contempt and fear in people who have similar views. There is no need to build anything - emotions and 'arguments' are ready-made. This is also a shortcut to violence: since 'they' are like the Jews, then they are everywhere and plotting against 'us.' And if so, the you not only can but have to defend yourself. With stones, for example." 


\section{The gay of fashion}

Those events have their part in the changes in the images of the LGBTQ community in Polish cinema. The late 1980s and early 1990s, along with the abolition of censorship and an eruption - albeit momentary, as it was to turn out of emancipation, brought the increase in the representation of sexual minorities in the Polish cinema. Gays (lesbians were only shown sporadically in the domestic films ${ }^{9}$ ) marked their presence above all in the heritage films (e.g. Farewell to Autumn, Pożegnanie jesieni, Mariusz Treliński, 1990; Horror in Happy Swamp, Horror w Wesolych Bagniskach, Andrzej Barański, 1995), while their appearance in films with contemporary settings was only occasional (e.g. Time for Witches, Pora na czarownice, Piotr Łazarkiewicz, 1993). The thriving of the gangster cinema and the reign of the strong manhood caused that the images of gays were then dominated by shameful stereotypes, a "faggot" (Krugerandy, Wojciech Nowak, 1999), a dangerous deviant (Deborah, Ryszard Brylski, 1995; Weekend Stories: Harlot Charm, Opowieści weekendowe: Urok wszeteczny, Krzysztof Zanussi, 1996) or a suffering decadent artist (Nocturnal Birds, Nocne ptaki, Andrzej Domalik, 1992; Egoists, Egoiści, Mariusz Treliński, 2000). Gays disappear from the Polish screens together with the fading away of the momentum of the first wave of emancipation in the mid-1990s, but they return in the 2000s when the macho type was put out to pasture and was replaced by a man who did not fulfil himself in dominance and aggression. The slightly greater visibility and greater diversity in creating queer images were influenced by a lot of interrelated factors. Firstly, the political and social activism of the sexual minorities prompted by the discriminating policy of the Law and Justice (2005-2007, 2015-). Secondly, the transformation of the understanding of the human gender and sexuality, inspired by considerations in the style of gender studies and queer theory developing in the West. Thirdly, the blossoming of the queer cinema and unprecedented diversity of images of the LGBTQ people in the American and West European mainstream cinema.

9 Representation of lesbians in the Polish cinema after 1989 is definitely less common and typically episodic; however, like gays, lesbians do appear on the Polish screens along with the emancipative waves of the early 1990s and late 2000s, to mention such films as: Femina (Piotr Szulkin, 1990), In Flagranti (Wojciech Biedroń, 1991), White Marriage (Białe małżeństwo, Magdalena Łazarkiewicz, 1992), Two Moons (Dwa księżyce, Andrzej Barański, 1993), Seven Stops on the Way to the Paradise (Siedem przystanków na drodze do raju, Ryszard Maciej Nyczka, 2003), Aria Diva (Agnieszka Smoczyńska, 2007), The Perfect Guy for My Girlfriend (Idealny facet dla mojej dziewczyny, Tomasz Konecki, 2009) or Oh, Charles! 2 (Och Karol 2, Piotr Wereśniak, 2011). 
The fear-provoking, depraved "faggot" or the grotesque old queer occupying railway stations and parks were replaced in the 2000s by other images in the films serving the affirmative policy-telling stories of the coming out of the closet - the independent Homo Father (2005) by Piotr Matwiejczyk and the short story Sleepiness (Senność, 2008) by Magdalena Piekorz. In both of them, homosexual couples resemble ordinary heterosexual couples, in both of them gays are persecuted and in both of them there appear strong accents targeted at the homophobic right wing. But it was not those quasi-emancipative films - of limited distribution, let us add - that showed gays to both Polish men and women. They saw the gay first of all in popular romantic comedies in which he appeared as the bourgeois gay of fashion. He can be tolerated but only when he conforms to the prevailing norm. No way for him to be himself. Marcel (Marcin Bosak) from Expecting Love (Mała wielka miłość, 2008) by Łukasz Karwowski dresses up in colourful things and when a friend (Agnieszka Grochowska) begins to give birth, he unexpectedly passes out (his maternal instinct is stronger than that of the future mother). The man, as befits a new buddy film, does everything in his power so that his friend may finally find her Prince Charming. But should he find his own Prince Charming is of no interest to the director. Marcel, whose life we know nothing about, only exists to such an extent that is needed by his female friend. In Female-Male War (Wojna żeńsko-męska, 2011) by Łukasz Palkowski, in turn, the thirty-year-old gay "Pe" (Wojciech Mecwaldowski) is - indeed - the best friend to women but only to those with traumatic experiences: forty-year-old Barbara (Sonia Bohosiewicz) and "Baba" in her mid-fifties (Grażyna Szapołowska). What do they have in common? Women after forty, as he explains, have "the same chances of finding a husband as myself in this country." What is more, he discusses with them ladies' jackets, high heels and neckerchiefs. He advises them not only on what they should wear ("you look like the Old Town after a bomb raid", he says to Barbara) but also on how to effectively pick up a man. Also "Pe" himself is successful in this task and he enters a relationship with the bossy Bartek (Tomasz Kot), editor of the Perverse Magazine for Ladies in which Barbara achieves success with her column in which she diagnoses men's personalities based on the size and shape of their penises. "Pe" does his best to keep his lover with him (he irons, cooks, wears G-strings, etc.), however to no avail. Gays, unlike forty-year-old women, are not meant to be happy in this world. In another comedy, Ladies (Lejdis, 2008) by Tomasz Konecki, the gay character played by Piotr Adamczyk is equally stereotypical and episodic. Artur is a member of the European Parliament and husband of one of the title "ladies", Gośka (Izabela Kuna), who wants to become pregnant by him. However, the repeated attempts fail. Nothing helps, whether fresh strawberries 
or champagne, incense sticks and even, as Gośka puts it, "whore thongs". Artur is ailing and that's that. At last, Gośka realises what it is all about: "Darling, I can't get a dick of my own", she says outraged. They split up but Artur soon returns in order to cry on her shoulder because his guy left him. So, the wife brews fresh mint for him. Well, a gay is a woman's best friend, even if he happens to be her husband too. With Karwowski, the gay of fashion is merely a trinket shimmering with colours; with Palkowski and Konecki, he already has some story, experiences ups and downs but all of this is free of any genuineness, anyway.

The homosexual in the latest popular Polish cinema will either be domesticated and devoured (he will be like the hetero) or he will be no more at all (at the best, he will be degraded to homophobic jokes, as in Weekend, Cezary Pazura, 2010). Gays on the screen are thus polite and do not have sex, nay! they do not even kiss. As in the Christmastime Letters to Santa (Listy do M., 2011) by Mitja Okorn where Wladi (Paweł Małaszyński) is looking for a girl who would be willing to assume the role of his fiancée during the family dinner on Christmas Eve. At the moment when Doris (Roma Gąsiorowska) leaves him in the lurch, he decides to come out and invites his partner, which is unexpectedly received with full acceptance by the family. Gays here are colourless, stiff and banal, albeit handsome. In the last scene, when love triumphs and all the heterosexual couples appear on the screen, that gay one is missing. As if the image of men in love were to annihilate the joy of the Christmas morning. The filmmakers expelled the gay couple from the film space, which did not prevent them from including the gay anthem Over the Rainbow in the soundtrack. Thereby, on the one hand, the domestication of the gay in romantic comedies causes him to be absorbed, devoured by the heteronormative system, but on the other hand, it contributes - despite the stereotypical aspect of those representations - to a greater visibility of homosexuals in the public sphere and thus to a greater social acceptance.

\section{Suicide Room}

It is from the emancipative policy of identity towards the queer-like understanding of diversity that Jan Komasa traverses in his debut Suicide Room. The director rejects the essentialist model based on the sharing by all gays and lesbians of a stable homosexual identity - a genesis searched for in common experience: desiring someone of the same sex and social oppression - for the benefit of the queer perspective, destabilising normative identity and questioning any and all actions founded on a stable and rigid identity, and demonstrating that such identities are performatively construed, manufactured, fabricated and generated through rituals 
of bodily symbols ${ }^{10}$. Thereby Komasa does not aim so much for the change of the negative approach of the heteronormative society towards gays and lesbians typical of politics of positive identity - as for the glorification of sexual diversity, so characteristic of the queer perspective.

The central narrative structure here - as in the case of In the Name of... and Floating Skyscrapers - is the motive of coming out of the closet. Dominik (Jakub Gierszał), the son of a high-ranking official in the Ministry of Finances (Krzysztof Pieczyński) and mother (Agata Kulesza) making career in the advertising industry, is in the final year at secondary school. He lives in a villa, a chauffeur drives him to private school, he often attends the opera (Orpheus and Eurydice by Gluck) with his parents. But everything is changed by his apparently innocent kiss with Aleks (Bartosz Gelner), which was meant to be a school-ball joke. However, during a judo training session when the boys' bodies are intertwined, Dominik has an erection. His body, so to say, speaks for him or rather - speaks in defiance of him. Roland Barthes wrote, "I can do everything with my language, but not with my body. What I hide by my language, my body utters"11. The class, who watched their colleagues' transgression at the ball with amusement and applauded, now humiliate, deride and reject the boy. The homophobic stigmatisation contributes to Dominik's being forced into a new "social constitution"12, a new social position that of subordination. Because an injurious word, as Butler writes, "does not only name something but also, in a sense, performs something, and in particular, (...) performs what it names"13. In Didier Eribon's opinion, gay identity is initiated by a stigmatising and excluding "word of insult" (e.g. "You faggot"), "The one who uses an insult makes me realise that they captured me and have power over me and that it is above all the power of injuring. The power of injuring my consciousness by inscribing shame into the deepest corners of the soul. This injured consciousness, being ashamed of itself, becomes the constitutive element of my identity"14.

10 Cf. Judith Butler, Gender Trouble. Feminism and the Subversion of Identity (London and New York: Routledge, 1990); Eve Kosofsky Sedgwick, The Epistemology of the Closet (Berkeley and Los Angeles: University of California Press, 1990); Judith Butler, Bodies that Matter. On the Discursive Limits of "Sex." (London and New York: Routledge, 1993).

11 Roland Barthes, A Lover's Discourse: Fragments, trans. Richard Howard (London and New York: Penguin Books, 1990), p. 44.

12 Judith Butler, Excitable Speech. A Politics of the Performative (London and New York: Routledge, 1997), p. 18.

13 Judith Butler, Excitable Speech, p. 43.

14 Didier Eribon, Réflexions sur la question gay (Paris: Fayard, 1999), p. 30. 
Gay identity is constituted through a performative act of putting someone to shame $^{15}$. Before he moves to the virtual world of avatars, Dominik will boldly challenge the stigmatisation. He will defy the school persecution with the queer strategy of "combat makeup"16. Because, as Butler remarks, "the injurious address may appear to fix or paralyze the one it hails, but it may also produce an unexpected and enabling response"17. Dominik's response will be a provocative rejection of the obligatory heterosexuality. Dark makeup and black nail varnish provide the strategy of resistance staged on the surface of the body, a way of expressing his rebellion, his dissent to the school oppression; it is a way to manifest his self-confidence even if this self-confidence were to be merely a mask hiding pain and fear. The strategy proves effective as no one dares to insult the boy in public, and Aleks does not even look him in the eyes. Queer strategies will prove helpful again when Dominik comes out at the opera. The coming out is here a subversive, strongly theatricalised performance rather than a painful confession: Having confessed the truth, Dominik demonstratively kisses a Greek statue on the lips. This confession is so conspicuous that the parents and their friends accompanying them mistake it for a juvenile prank. The mother talks about "a fashion for gayness" and the father advises him that, if he actually is a gay, he should keep it to himself. Dominik then locks himself in his room, escaping the reality into the world of virtual avatars. This escape essentially closes the gay narrative and opens a narrative that belongs to a heterosexual romance, albeit virtual. Virtual, i.e. unreal. Dominik falls in love with a phantom girl. If they met in reality, the affection would probably burst as quickly as a soap bubble. But the second (heterosexual) part of the film does not by any means negate the first (gay) one, nor does it break with the queer view of the world, which emphasises the instability and fluidity of sexual identity. The director himself talked about it, "I have a problem with the terms homo or hetero. I think this is so fluid. (...) Those who depart from the norm are very many, a certain queer style has formed now. We observed such situations at a school-ballgay narrative. We attended such a ball

15 Cf. Eve Kosofsky Sedgwick, Touching Feeling. Affect, Pedagogy, Performativity (Durham and London: Duke University Press, 2003), pp. 35-66; Heather Love, Feeling Backward. Loss and the Politics of Queer History (Cambridge, Massachusetts and London: Harvard University Press, 2007).

16 Błażej Warkocki, Różowy język. Literatura i polityka kultury na początku wieku [Pink tongue. Literature and cultural policy at the beginning of the century] (Warszawa: Wydawnictwo Krytyki Politycznej, 2013), p. 234.

17 Judith Butler, Excitable Speech, p. 2. 
before the film and I decided to recreate such things"18. But nothing of this kind can be found in reviews published by the papers. There, the Suicide Room turns out to be a completely heterosexual film.

It was accurately captured by Błażej Warkocki,

When (...) I was walking out of the cinema after the screening of the Suicide Room, my primary thoughts were that I had just seen the first Polish gay film, and not a bad one at that. With a full house and the silent but noticeable approval of the young audience. However, it soon turned out that I was wrong. Listening to the actors' statements, watching the trailer, reading the reviews or interviews with the director, I was convinced that the film was universal. In short, it sounded like this: parents, go with your children to see the Suicide Room and you will see the effects of the lack of communication and the dangers lurking on the Internet for sensitive young souls. The gayness has either disappeared altogether or it appeared to be there after all but with absolutely no significance because it is not what the film is about ${ }^{19}$.

An example of the former of the strategies recalled by Warkocki is a review published in the Kino [Cinema] monthly where the reviewer does not mention the gay thread at all, which is obviously not easy because the entire dramatic structure of the work relies ${ }^{20}$ on it. Yet we read, "Because the director asked before the screening not to reveal too many details of the plot, I will but mention that one day Dominik will find himself on a shaky ground"21. The reviewer notes that Komasa made an "important" film as it shows the problem of Internet addiction. The gay issue disappears completely from the plot in this approach. The latter strategy, which is aimed at proving that the homosexuality that is present in the film is void of meaning, is excellently illustrated by the review by Tadeusz Sobolewski. Admittedly, the reviewer of the Gazeta Wyborcza [Electoral Newspaper] daily notices that this thread is essential, "The key but hardly touched upon psychological thread of the Suicide Room is related to Dominik's 'gayness' sealed

18 This comment is taken from TV programme shown on TVP 2, recorded soon after the Gdynia Film Festival, where the Suicide Room won the Silver Lion prize. In earlier interviews, the director was silent about Dominik's sexual identity.

19 Błażej Warkocki, Różowy język, p. 232.

20 Also the film distributor did of great job here when he wrote in promotional materials, "Dominik (...) has a lot of friends, dates the prettiest girl at school (...) and one day one kiss changes everything." These materials, deliberately of course, mislead the spectator suggesting the hero's heterosexuality. In the film, there is no mention of Dominik having a girlfriend. These materials deliberately fail to inform that the said kiss is not heterosexual.

21 Piotr Śmiałowski, „Sala samobójców“ [Suicide Room], Kino, No. 3 (2011), pp. 70-71. 
with a sort of rape - to what extent assumed and to what genuine?"22. The word "gayness" was put in inverted commas, which suggests to us that the gayness was only pretended here; that it is a mask covering something else; that it is just a pretext. "Well, indeed", continues Sobolewski, "Here lies the heart of the drama: the moment when the immature boy, deprived of any contact with his father, assumes the homosexual role imposed upon him by the milieu; what is more, he attempts to play the game in his rebellion against his parents" 23 . Thus, homosexuality turns out to be a mere game and a way to attract the parent's attention. According to the critic, Dominik does not fall in love with his classmate; quite contrary, he experiences "genuine love" for a girl: "The desperateness of his situation (...) consists in that taking part in an insane game [the virtual reality of avatars - SJ], the boy experiences genuine love, such as he never experienced in the real world"24. The reader of Sobolewski's review has thus no doubts any more. A film that became a box-office hit in Poland could not be gay after all. The gay reception of the Suicide Room is altogether different. Krzysztof Tomasik asserts that Komasa has treated the gay thread schematically and marginally to abandon

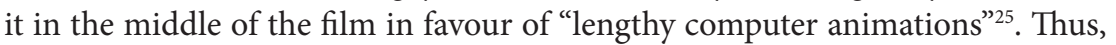
the columnist did not find in this film the expected traditional gay narrative. Warkocki, in turn, commented on the film, "we received a not so bad Polish semigay film with a queer solution and one leg in the closet" 26 . The literature reviewer criticises the metamorphosis of the gay narrative into a universal narrative but, contrary to Tomasik, paradoxically points to its advantages: "A universal film is likely to attract more people than a gay one. School homophobia (...) can be defined as a universal problem. And this is at least something - in circumstances where Polish pedagogues just wash their hands"27.

\section{Conclusion}

The Polish cinema increasingly less commonly puts the gay to death, increasingly less commonly punishes and stigmatises him. And it less commonly makes fun of him. However, both the depraved "faggot" and the dandified gay of fashion are

22 Tadeusz Sobolewski, „Emo hipnotyczny i martwy“ [Emo hypnotic and dead], Gazeta Wyborcza, 3.03.2011, p. 14.

23 Tadeusz Sobolewski, "Emo hipnotyczny," p. 14.

24 Tadeusz Sobolewski, "Emo hipnotyczny," p. 14.

25 Krzysztof Tomasik, "Sala samobójców” [Suicide Room], Replika, No. 30 (2011), p. 24.

26 Błażej Warkocki, Różowy język, p. 236.

27 Błażej Warkocki, Różowy język, p. 236. 
equally unrepresentative. The ideal, thus, is such diversity that would reflect the complexity of the non-normative experience ${ }^{28}$. Even if the Polish cinema more and more frequently assimilates queers, it does so on its own (normative) terms. In Magdalena Podsiadło's opinion, "the society of ostensible tolerance (...) would be happy to get rid of the queer but it falls victim to the schemes and norms including the declared tolerance of the post-emancipative society that is merely a theory while people know better anyway" 29 . The fashionable gay, well, why not, but only as a walk-on part; on the other hand, a story about gay-bashing will probably be touching to the more enlightened part of the audience sensitive to harm done to others. There's not a scintilla of truth in it. But at least no one will be able to accuse the Polish cinema of promoting homophobia.

Thus, what is the epochal character of Szumowska's and Wasilewski's films actually based on? Above all, In the Name Of... and Floating Skyscrapers are films that place gay problematics at the centre of narration and are brimming with particularly in the case of Wasilewski's film - gay stylistics and erotica. The central narrative structure of both films presents the process of coming out of the closet. Coming out, on the one hand, signifies recognition of the truth about oneself, the truth hidden thus far, forced out or altogether subconscious or barely sensed, and on the other hand, it signifies the revealing of the truth about one's own sexuality before others. Because queers, in order to avoid being excluded and stigmatised (or sentenced to prison), were for years forced to hide their sexual identity ${ }^{30}$. The

28 Harry Benshoff, "(Broke)back to the mainstream: queer theory and queer cinemas today," in: Film Theory and Contemporary Hollywood Movies, ed. Warren Buckland (New York and London: Routledge, 2009), pp. 193.

29 Magdalena Podsiadło, „Kochający inaczej. Homoseksualizm na ekranie“ [Those who love differently. Homosexuality on the screen], in: Odwieczne od nowa. Wielkie tematy w kinie przełomu wieków [The timeless anew. Great topics in the cinema at the turn of the century], ed. Tadeusz Lubelski (Kraków: Rabid, 2004), pp. 143. Cf. also: Suzanna Danuta Walters, All The Rage: The Story of Gay Visibility in America (Chicago: University of Chicago Press, 2001), p. 161; Harry Benshoff and Sean Griffin, Queer Images. A History of Gay and Lesbian Film in America (Oxford: Rowman \& Littlefield Publishers, 2006), p. 261.

30 Tomasz Basiuk, "Coming out po polsku" [Coming out the Polish way], in: Queer studies. Podręcznik kursu [Queer studies. Course handbook], ed. Jacek Kochanowski, Marta Abramowicz, Robert Biedroń (Warszawa: Kampania Przeciw Homofobii, 2010), pp. 115,121 . Basiuk notes that, "a coming out typically has a narrative character, even dramatic - it is a confession of a breakthrough, describing the discovery of the truth about oneself where this truth concerns sexuality." It is no wonder then that the gay and lesbian cinema based its narrative structures above all on the formula of coming 
action of In the Name of... is set in motion by the scene in which the priest Adam (Andrzej Chyra) is watching from a concealed place as his pupils are having sex. After this shock, he falls into alcoholism, seeks assistance in a church but this is locked, weeps to his sister, who knows better that he cannot be a "faggot" because he always used to like girls. It is first an ordinary lad from a village in the Masurian Lake District, nicknamed “Dynia” [lit. "Pumpkin”] (Mateusz Kościukiewicz), that gets him out of the crisis and unexpectedly follows in his footsteps. So, there will be no happy ending: although it would be consistent with the emancipative narration, it would not prove likely in the Polish provincial reality. In the last scene we see "Dynia" in a seminary.

The Floating Skyscrapers in turn tells the story of a traumatic coming out of the closet of two boys in love with each other: Michał (Bartosz Gelner) and Kuba (Mateusz Banasiuk). But the profound pessimism of the film is not so much related to the overt homophobia depicted here but rather to the lack of space for expressing oneself, one's emotions and desires. A quick fellatio in the swimming pool toilet, anal sex in an archway (shown explicitly and not merely suggested), passionate kisses in front of the block of flats but never inside flats where it is only heterosexual love that can be pursued. Even Michał's conversations with his mother about his sexuality, which precede the coming out before his father, take place in a car. For the LGBTQ there is no place anywhere. Poland, the director seems to suggest, is not a place for queers.

However, the ground-breaking character of In the Name Of... and Floating Skyscrapers is also based on the fact that the movies actually made it into the mainstream. Mainly due to their awards at international festivals (Teddy Awards at the Berlinale for the film by Szumowska, the Grand Prize at the East of the West competition at the Karlovy Vary International Film Festival for Wasilewski) and the distribution and reception abroad, thanks to which they could not be ignored. These films may be banned (the right-wing party Prawo i Sprawiedliwość [Law and Justice], after regaining power in 2015 and taking control over the public media, forbade the film by Szumowska to be shown on public television) but they cannot be passed over in silence. Furthermore, Wasilewski and Szumowska were followed by other directors. Since the premieres of In the Name of... and Floating Skyscrapers, there have appeared several important and esteemed films that place non-normative sexuality and non-normative lust - especially, which

out of the closet. A coming out is usually depicted as a liminal and breakthrough moment, and thus "burdened with risk and requiring courage". However, the revealing of the truth about one's own sexuality usually bears the fruit of social integration and acceptance, however uneasy that might be. 
is essential, between women - in the very centre of the narration, among others in The Lure (Córki dancingu, Agnieszka Smoczyńska, 2015), United States of Love (Zjednoczone stany miłości, Tomasz Wasilewski, 2016) or Nude Area (Strefa nagości, Urszula Antoniak, 2014). To the young Polish filmmakers - Agnieszka Smoczyńska, Tomasz Wasilewski, Kuba Czekaj or Małgorzata Szumowska - it is obvious that the diversity of gays and lesbians, the style of our culture can have a positive and refreshing effect on the development of the cinema and the entire culture. Thus, the diversity and distinctiveness of the LGBTQ community is not something that should be overcome but a strength that should be exploited.

\section{Bibliography}

Barthes, Roland. A Lover's Discourse: Fragments, trans. Richard Howard. London and New York: Penguin Books, 1990.

Basiuk, Tomasz. "Coming out po polsku”. In: Queer Studies. Podręcznik, ed. Jacek Kochanowski, Marta Abramowicz, Robert Biedroń. Warszawa: Kampania Przeciw Homofobii, 2010, pp. 115-124.

Benshoff, Harry. "(Broke)back to the mainstream: Queer theory and queer cinemas today". In: Film Theory and Contemporary Hollywood Movies, ed. Warren Buckland. London and New York: Routledge, 2009, pp. 192-213.

Benshoff, Harry, Sean Griffin. Queer Images. A History of Gay and Lesbian Film in America. Oxford: Rowman \& Littlefield Publishers, 2006.

Brooke, Michael. "Poland'scoming out". Sight and Sound, 18.02.2014, http://www.bfi. org.uk/news-opinion/sight-sound-magazine/features/poland-s-coming-out. (1 Feb. 2017).

Butler, Judith. Bodies That Matter. On the Discursive Limits of "Sex". London and New York: Routledge, 1993.

Butler, Judith. Excitable Speech. A Politics of the Performative. London and New York: Routledge, 1997.

Butler, Judith. Gender Trouble. Feminism and the Subversion of Identity. London and New York: Routledge, 1990.

Eribon, Didier. Réflexions sur la question gay. Paris: Fayard, 1999.

Graff, Agnieszka. Rykoszetem. Rzecz o płci, seksualności i narodzie. Warszawa: W.A.B., 2008.

Kosofsky Sedgwick, Eve. The Epistemology of the Closet. Berkeley and Los Angeles: University of California Press, 1990.

Kosofsky Sedgwick, Eve. Touching Feeling. Affect, Pedagogy, Performativity. Durham and London: Duke University Press, 2003. 
Kulpa, Robert, Joanna Mizielińska. (eds). De-Centring Western Sexualities: Central and Eastern European Perspectives. Surrey: Ashgate, 2011.

Leszkowicz, Paweł, Tomek Kitliński. Miłość i demokracja. Rozważania o kwestii homoseksualnej w Polsce. Kraków: Aureus, 2005.

Love, Heather. Feeling Backward. Loss and the Politics of Queer History. Cambridge, Massachusetts and London: Harvard University Press, 2007.

Mizielińska, Joanna. "Idee pogubione w czasie - polityka LGBT vs teoria queer w Polsce i na Zachodzie”. Przegląd Kulturoznawczy, Vol. 13, No. 3, 2012, pp. 287-301.

Podsiadło, Magdalena. "Kochający inaczej. Homoseksualizm na ekranie”. In: Odwieczne od nowa. Wielkie tematy $w$ kinie przełomu wieków ed. Tadeusz Lubelski. Kraków: Rabid, 2004, pp. 139-159.

Sobolewski, Tadeusz. "Emo hipnotyczny i martwy”. Gazeta Wyborcza, 3.03.2011, p. 14.

Sypniewski, Zbyszek, Błażej Warkocki. "Wstęp”. In: Homofobia po polsku, ed. Zbyszek Sypniewski, Błażej Warkocki. Warszawa: Sic!, 2004, pp. 5-13.

Szulc, Łukasz. "Queer in Poland: under construction”. In: Queer in Europe: Contemporary Case Studies, ed. Lisa Downing, Rober Gillett, Surrey: Ashgate, 2011, pp. 159-172.

Śmiałowski, Piotr. “Sala samobójców.” Kino, No. 3, 2011, pp. 70-71.

Tomasik, Krzysztof. “Sala samobójców." Replika, No. 30, 2011, p. 24.

Walters, Suzanna Danuta. All the Rage: The Story of Gay Visibility in America. Chicago: University of Chicago Press, 2001.

Warkocki, Błażej. "Biedni Polacy patrzą na homoseksualistów.” In: Homofobia po polsku, ed. Zbyszek Sypniewski, Błażej Warkocki. Warszawa: Sic!, 2004, pp. $151-169$.

Warkocki, Błażej. Różowy język. Literatura i polityka kultury na początku wieku. Warszawa: Wydawnictwo Krytyki Politycznej, 2013, pp. 231-236. 



\author{
Bartłomiej Nowak
}

Uniwersytet Jagielloński

\title{
10. To be or not to be yourself: Turkish diaspora and the foreign land - stereotypes, nation and (hetero)norms
}

\begin{abstract}
The author analyses a few films of the German-Turkish and Austrian-Turkish cinema directed by Fatih Akın, Kutluğ Ataman and Umut Dag. He's interested in the functioning of the Turkish diaspora in the German-language societies of the West, and in topics of cultural differences, gender, sexual identity and changes of the forms of traditional Turkish family.

Discussing such problems as honour killings, patriarchalism and homophobia of Muslim diasporas, he tries to answer the question if diasporic cinema is able to change stereotypical perception of the ethnic minorities. Can it play with the meaning of such concepts as "family" and "nation"?
\end{abstract}

Keywords: German-Turkish, Austrian-Turkish cinema, gender, sexual orientation, stereotypes, identity

In this short chapter, I will analyse a few films directed by Fatih Akın, Kutluğ Ataman and Umut Dag dealing with the functioning of the Turkish diaspora in the German-language societies of the West. I'll try to answer the question if diasporic cinema can change stereotypical perception of the ethnic minorities and redefine categories of "family" and "nation."

Films such as Akın's The Edge of Heaven (Auf der anderen Seite, 2007), Ataman's Lola + Bilidikid (Lola and Billy the Kid, 1999) and Dag's Kuma (2012) show that "clash of civilisations" should not be perceived in the categories derived from the classical theoretical work of Samuel P. Huntington who treated these words quite literally, foreseeing real face-offs of cultures built on different foundations, beliefs and meanings, but the ones closer to the current cross-cultural dialogue that takes place in a more private space. I'll try to check if heteronormativity and gender norms of the Turkish diaspora play the significant role in the life of the films' protagonists or if the Western context changes significantly the way in which they perceive themselves.

Let me begin with Kuma. The main protagonist of this film, Ayse (Begüm Akkaya), is a young woman who in the first scenes of the film (which take place in Turkey) is wed to the young and handsome Hasan (Murathan Muslu) with 
whom she later moves to Vienna. Though the title of the film (which literally means "concubine" or "second wife") doesn't hide the true role of Ayse in the Hasan's family, the first scenes of the film do not explain if Ayse is aware of this role and whether she knows that her marriage to Hasan is just a guise to bring her to Austria as the concubine of Hasan's father whose first wife, Fatma (Nihal G. Koldas), supposedly terminally ill, wants to be sure that her children won't be motherless after her death.

For quite some time, Dag doesn't reveal Hasan's motives to agree to such a marriage. The viewers are confronted with the truth when Ayse, who falls in love with Hasan, is informed by him that he is not interested in women. However, it is unclear till the end of the film if his parents were aware of his homosexuality when they decided to arrange his marriage and if this marriage was planned to hide his true sexual leanings from the local Turkish community.

When, quite unexpectedly, Hasan's father passes away, Ayse's position in the family changes and she has to start working in the local store. There she starts an affair with a young Turkish man. She spends her time off with Hasan's mother, Fatma, looking after her, even sleeping with her in the same bed. Their relation is full of kindness, mutual respect, even intimacy. It changes when Ayse is caught in the store in flagrante with her young lover. The feeling of betrayal overwhelms Fatma, who turns against Ayse, beats her with fury and wants to chase her away from their apartment. One of the reasons of her anger is the fact that her daughterin-law's adultery was witnessed by the store's owner so there's a whiff of scandal in the story which may dishonour her son. Honour of the family is very important for the Muslim diasporas all over the world, the topic I will come back to later.

Ultimately, it is Hasan who helps his wife to stay in the family and probably - it is uncertain due to the open ending in the final scene - alleviates the crisis. This stabilisation is connected, though, with the need to continually lie about Hasan's and Ayse's marriage. This lie is from the beginning present in her relationship with her lover: she may consider herself a widow (after Hasan's father's death) but for her diaspora she's a woman betraying her husband.

Films about young Turkish women and their situation in the patriarchal surroundings of their families have been made by the German-language cinema for years. Ewa Fiuk in her Polish text about German-Turkish cinema cites Forty Square Meters of Germany (40 Quadratmeter Deutschland, 1985), directed by Tevfik Baser, about a wife kept by her husband in their apartment to - as he claims - guard her from the allegedly demoralising influence of the German reality. The same topic is present in Head-On (Gegen die Wand, 2004), directed by Fatih Akin, which probably is still the most widely known film of the German-Turkish 
cinema. The main female protagonist of the film, Sibel (Sibel Kekilli) meets Cahit (Birol Ünel) and marries him to escape the patriarchalism of her family. After some time, it becomes clear that Cahit, allegedly as rebellious as his wife against their diaspora's norms, is as patriarchal as (we may assume) Sibel's father. His patriarchal jealousy is one of the reasons why he kills one of his wife's lovers.

In Kuma, this topic is treated differently, mainly because of Hasan's homosexuality, which interferes with the codified family's relations and at the same time (especially in the final scenes of the film) is the guarantor that lets the family keep its status quo. Hasan does not want to reveal his sexual orientation (to "come out of the closet") so he does not strive to defend the family's honour by banishing Ayse from his family. The wives' adulteries in the Muslim communities of the West are very often punished by the so-called "honour killings." They are notorious among the members of the Turkish diaspora in the German-language countries. Between 1996 and 2005, there were as many as fifty-five honour killings in Austria and their number does not change from year to year. They take place as often in Turkey as in the Turkish communities all over the world. Monika Lisiewicz (2012) in Polish text Społeczności LGBT w Turcji: między kemalizmem a westernizacja (LGBT communities in Turkey: between Kemalism and westernisation) claims:

The last research commissioned by the Turkish government showed that there are on average one thousand victims of the honour killings every year - compare it with sixtysix people murdered in 2002 [data from 2011]. Usually the victims are young women murdered by their male relatives for having extramarital relations, talking with strangers or being rape victims ${ }^{1}$.

Homosexuality is another important reason for "honour killings"; therefore, it might be said that Hasan's situation in the community of Austrian Turkish diaspora is very similar to Ayse's situation. This might explain why Hasan defended Ayse when Fatma became aware of her extramarital affair.

The "honour killing" of the homosexual young man is one of the subjects of the film Lola + Bilidikid. This film about homosexual and transgender Turkish Germans tells a story of three brothers and their attitude to their sexual orientation. When writing about the sexuality of the Turks, Lisiewicz writes: "As the results of research of the Turkish society's sexuality suggest, $25 \%$ of the people under the age of 30 felt or still feel sexual attraction to the person of the same sex" ${ }^{2}$ and

1 Monika Lisiewicz, "Społeczności LGBT w Turcji: między kemalizmem a westernizacją," in: Queer a islam. Alternatywna seksualność w kulturach muzutmańskich, ed. Katarzyna Górak-Sosnowska (Sopot: Smak Słowa, 2012), p. 189.

2 Lisiewicz, “Społeczności LGBT," p. 195. 
there is no reason, I suppose, to think that this percent is lower for members of the Turkish diaspora living outside Turkey. Additionally, it is worth remembering that honour killings of the homosexual men are very often committed by men who - as Lisiewicz writes - "had sexual intercourse with their victims"3. Attitude to homosexuality is quite different in Turkey than in the West and these differences might explain why we've read here about percentage as high as $25 \%$ (when most of the research in the West claim that only around 5\% of people are gay). I'll come back to this topic once again later.

The youngest of three brothers portrayed in Lola + Bilidikid, Murat (Baki Davrak), has just started his adolescence and seeks his first erotic experiences. The oldest one, Osman (Hasan Ali Mete), gives the impression of the heterosexual macho and the homophobe. Suspecting that Murat is gay, Osman tries to force him to have sex with a prostitute. However, it is later revealed that Osman, when informed about homosexuality of his second brother, Lola (Gandi Mukli), raped him. Later in the film, when Lola, previously banished from the family, meets and befriends Murat, Osman murders her, presumably to hide his own homosexual tendencies, which might have been revealed if Lola told his family about being raped by her brother. As I've written before (citing Lisiewicz), such murders are very often committed as attempts to hide the murderer's sexual experiences.

When Murat meets Lola, she performs as a drag queen in gay clubs and lives with Bilidikid (Erdal Yildiz) who sells himself to other men for Deutschmarks. "Selling himself" means here that he lets other men perform fellatio on his penis but does not do anything else. His treatment of his own sexuality is another subject. He clearly loves Lola but at the same time is ashamed of living with a man. He tries to convince Lola to move to Turkey and pursue sex reassignment surgery (and marry him later). This clearly contradicts with her wishes: despite being transgender, Lola does not want to change her sex surgically. She even foresees that if she decided for such a step, Bilidikid would leave her for not being built like a man anymore.

An attitude to homosexuality in Turkey (and therefore in Turkish diaspora) was formed not only by Islam but also by Atatürk's cultural revolution and the influence of the modern Western discourse about gender and sexual identity. Obviously, the Western context and Western customs cannot be forgotten when someone tries to talk about the subject of life and identity of German-Turkish men having sex with other men. Lisiewicz writes:

3 Lisiewicz, “Społeczności LGBT,” p. 190. 
In the Muslim world ... there was ... a wide margin of freedom for crossing borders of heteronormativity. It had its roots in the legacy of the classical Islam which sanctioned roles for transgender persons and also in the influence of the local customs and cults present on these lands before Islam ${ }^{4}$.

It might be suggested ${ }^{5}$ that changes introduced in Turkey after Atatürk's cultural revolution, which tried to incorporate Western customs into Turkish society, were among the reasons behind the change in the attitude of Turks toward gender, masculinity and femininity. All departures from gender or sexual norms (and by "norms" I mean, among others, borders between masculinity and femininity that allegedly should not be transgressed) were seen as "part of the past". Nonheteronormative sexuality is defined in Turkish language in various terms but for us the most interesting information should be this: long are traditions of different perceptions of passive and active partners in sex. Only passive ones were perceived as "unmanly", and this asymmetrical perception results from the cultural belief that man is the one who, during sexual intercourse, penetrates the body of his lover and woman is the one who is penetrated (so the act of being penetrated is always feminine and therefore unmanly).

This belief might explain why Bilidikid does not perceive himself as homosexual. We cannot be sure but his "macho" style and the fact that he wants to convince Lola to sex reassignment surgery suggest that he might be an active partner in sex and therefore in his own eyes (and as a result of the aforementioned perception of male homosexuality in Turkey and Turkish diaspora) he isn't "unmanly." Heteronorms of the Turkish diaspora, not necessarily identical as hetero-norms of the Western world, connect with his identity and let him perceive himself as the "real man," even if he's in love with another man.

Homosexuality (but this time lesbian) and the situation of women in the Muslim communities are two of many subjects of The Edge of Heaven. The female protagonist from Turkey, Ayten (Nurgül Yeşilçay), is Kurdish. When she escapes from Turkey and seeks asylum in Germany, she meets Lotte (Patrycja Ziółkowska). The women fall in love with each other. When Ayten is expelled from Germany, Lotte travels after her to Turkey. This is one of many subplots of Akin's film but the one representative for its themes of cultural identity and Eastern/Western dichotomy. When writing about the film, Ewa Fiuk draws our attention to the fact that Akin shows both sociological and political problems of Turkey and does

4 Lisiewicz, “Społeczności LGBT,” p. 184.

5 Lisiewicz, “Społeczności LGBT," p. 185.

6 Lisiewicz, “Społeczności LGBT," p. 185.

7 Lisiewicz, "Społeczności LGBT,” p. 186. 
not forget about exclusions still existing in the Western societies. Despite the fact that Ayten is in love with a German female citizen, she can't receive German citizenship through marriage with her beloved because gay marriages aren't legally established yet ${ }^{8}$. Paradoxically, the victim of this social injustice is German: Lotte travels to Istanbul after Ayten and she is killed there mainly because Ayten could not stay in Lotte's homeland.

There's also another story told in The Edge of Heaven: the one of Yeter (Nursel Köse), Ayten's mother, a prostitute who abandons her profession to live with Ali Aksu (Tuncel Kurtiz), an older man who is aware of her past and seems to accept it but later is jealous of her alleged (but non-existing) relationship with his son, Nejat (Baki Davrak). Yeter dies in an accident, which happens during a quarrel with Ali. His rage is unsubstantiated and irrational but is undoubtedly connected with his patriarchal upbringing. Her profession of sex worker was good enough for him as long as her sexual experience could be tamed and used only for his own pleasure. When his "ownership" of woman's body is called into question, rules of patriarchy prevail. The situation of women in Turkish family is treated here in a similar way to the one in Kuma and many other films dealing with the identity of Muslim diasporas all over the world: Akın shows that traditional ways of living of the Muslim communities might change in the Western context but the Turkish identity is still the result of a dialogue between two cultures and two types of thinking about gender, sex, family etc. It is almost impossible (or at least very difficult) to forget about one's upbringing, religion, and a way of thinking, and assimilate with the Western society in a way that would eliminate all differences. People belonging to Muslim diasporas create their identity as a bridge between two river banks of two different cultural worlds.

The "marginalisation" of the films' protagonists mentioned in this chapter is the result of their ethnic roots, their gender or their sexual orientation. An American female theoretician, bell hooks, claims that marginality is not "a site of deprivation" but it can be "the site of radical possibility, a space of resistance"10 and from this "site" people of margins can talk about their life, their world and their experiences: marginality may be "a central location for the production of

8 Ewa Fiuk, "Kobieta - Inna, Obca. Bohaterki i autorki współczesnego niemieckiego kina migracyjnego," in: Między filmem a teatrem II. Napięcie i poznanie. O inter-, multi- i transkulturowej komunikacji w sztukach audiowizualnych, eds. Sławomir Bobowski and Piotr Rudzki (Wrocław: Wydawnictwo Uniwersytetu Wrocławskiego, 2014), pp. 159-160.

9 bell hooks, "Marginality as site of resistance," in: Out There: Marginalization and Contemporary Cultures, eds. Russell Ferguson and others (Cambridge: MIT Press, 1990), p. 341.

10 hooks, "Marginality," p. 341. 
a counter-hegemonic discourse that is not just found in words but in habits of being and the way one lives"11. We should ask if the aforementioned films try to be "the site of radical possibility, a space of resistance", if they let margins to find their own voice, to show how they see and understand the world.

Homi K. Bhabha adds to these hooks' observations that the space of nation, though it is seemingly formed in opposition to other nations and in a way, tries to overlook marginal groups that live in this space, cannot (even if it wants) ignore those that step in its borders: The Others. The cultural otherness has to be an issue when the subject of nation is analysed and nation itself is defined ${ }^{12}$. Films about national "otherness" very often (as we've seen already in this chapter) have protagonists that are "other" in many ways: their gender or sexual identity is usually an issue that can put their cultural, ethnic and national identity into question, that can show cultural inadequacies and the enslaving nature of cultural norms.

The narrative of the nation is very often one-sided - and it does not matter if this sentence is used for the nation of diaspora or for the one of the country in which it settles. It's true in both cases. Diasporic films show "scratches" existing on the surfaces of these narratives and show that national discourse (very often connected with the gender discourse), enforcing its authority, its power, is at the same time condemned to failure in its pursuance to create one image of nation. In Kuma, the rules of "typical" Muslim family are supposedly followed or at least it should look like this to the accidental people. Dag lets us peep into Fatma's and Ayse's family, to stalk their privacy and because of this the viewer is informed that behind the veil of norms that they supposedly follow is another reality of lies and suppressed desires. The same accumulation of lies and conflicts is shown in Lola + Bilidikid and a result of the ferocious fight between personal needs and the cultural norms is there even more dreadful than in Kuma: Lola is murdered by her brother. We've also analysed the relation between Yeter and Ali Aksu in The Edge of Heaven and I've mentioned a few other examples (such as Head-On or Forty Square Meters of Germany) that show the same fight between traditional patriarchy and the authenticity of the gender and sexual needs.

Another topic very often touched upon by the diasporic cinema are generational differences. The older generation is (or at least should be) the bulwark of tradition. Mother of three brothers, main protagonists of Lola + Bilidikid, and Fatma in Kuma are such bulwarks. The younger generations are very often more

11 hooks, "Marginality," p. 341.

12 Homi K. Bhabha, Miejsca kultury, trans. Tomasz Dobrogoszcz (Kraków: Wydawnictwo Uniwersytetu Jagiellońskiego, 2010), p. 158. 
willing to find compromise between their needs, the realities of living in the West and the traditions of their diaspora. Lola from Ataman's film cuts herself off (or rather is cut off) from her family and her diaspora's traditional way of life. In Kuma, this discussion between the Western realities and the Eastern traditions is constantly ongoing (and - mainly because of the fact that Eastern norms are still respected and celebrated by the people of diaspora - needed to survive in the context in which the chains of norms are part of everyday life). This "discussion" takes place on someone's body, in the realm of gender and sexuality. Judith Butler (2010) in her well-known book Gender Trouble claimed that gender is "performed." I think that this statement should be enough for us here and I don't want to go any further into summarising her theory. Let me just say that functioning of gender and sexuality in the aforementioned films very often shows validity of Butler's views. Kuma's protagonists deceive people who do not belong to their family by performing (sic!) their gender roles for the outside world. It is also clear from the stories told in those films that gender roles are created (and written on someone's body) as heterosexual. Therefore, homosexuality of Hasan is hidden behind the costume of heterosexual role of Ayse's husband: his true nature is non-normative and therefore Hasan has to play someone else to be able to find himself in the "right" position in his diaspora. Lola, one of the title characters of Lola + Bilidikid, works on stage as a drag queen, literally performing in the costume of the female gender and at the same time showing that gender is only a costume. Films mentioned here show that playing parts is the everyday reality of the people belonging to different generations of the German Turks. Women have to play roles of wives, daughters and mothers, men of husbands, sons and fathers, but first and foremost all of them have to play their gender - even when their real selves remonstrate. Younger generation may treat norms that define gender and sexuality more liberally than the older one but even they cannot escape from them - they need to debate with them and create themselves in the realm of their power. When they rebel - they are victims of their culture, which leaves its marks on them. Fight between culture and identity is part of life of every human being who does not subordinate to the norms that captivate his true self - so this sentence may be used to describe the situation of people in Poland as well as in Germany, Austria or everywhere else - but the more conservative the culture, the greater is the need to pursue one's identity in a way that would let keep up oppressive appearances of the traditional gender and family roles.

All films mentioned in this chapter try to crack down stereotypes. But do they succeed? They show small, private "clashes of civilisations" happening in the everyday life of their protagonists and at the same time teach that one-sided perception 
of people belonging to "civilisation" is false, even impossible, and therefore that stereotypes are false, distorted visions of far more complicated human beings. The need to redefine themselves, their identity, is part of everyday life of main and supporting characters of Kuma, Lola + Bilidikid and The Edge of Heaven. Their identity is created at the point of contact of two different cultures. This need, even necessity is the site of such clashes that happen in the private space which at the same time coexists with the space of nation.

\section{Bibliography}

Bhabha, Homi K. Miejsca kultury. Trans. Tomasz Dobrogoszcz. Kraków: Wydawnictwo Uniwersytetu Jagiellońskiego, 2010.

Fiuk, Ewa. "Kobieta - Inna, Obca. Bohaterki i autorki współczesnego niemieckiego kina migracyjnego.” In: Między filmem a teatrem II. Napięcie i poznanie. O inter-, multi- $i$ transkulturowej komunikacji w sztukach audiowizualnych, eds. Sławomir Bobowski and Piotr Rudzki. Wrocław: Wydawnictwo Uniwersytetu Wrocławskiego, 2014, pp. 155-169.

hooks, bell. "Marginality as site of resistance." In: Out There: Marginalization and Contemporary Cultures, eds. Russell Ferguson and others. Cambridge: MIT Press, 1990, pp. 341-343.

Lisiewicz, Monika. "Społeczności LGBT w Turcji: między kemalizmem a westernizacją." In: Queer a islam. Alternatywna seksualność w kulturach muzułmańskich, ed. Katarzyna Górak-Sosnowska. Sopot: Smak Słowa, 2012, pp. 183-196. 



\section{Part 3: Stereotypes and Social Polarities}





\author{
Jadwiga Hučková
}

Instytut Sztuk Audiowizualnych, Uniwersytet Jagielloński, Poland

\title{
11. Exposed and concealed Roma conflict: Representation of contemporary Roma conflicts in Czech Republic, Slovakia, Poland and Hungary
}

\begin{abstract}
Roma conflict is one of the dominant issues that societies and cinemas of Eastern Europe should face. Recently, a variety of deeply touching films have been created such as Just the Wind (dir. Benedek Fliegauf) and Judgement in Hungary (dir. Eszter Hajdú). While the films show disgruntlement or even large-scale protests and riots, the films' plots rarely present the causes of such events.

Documentary film projects with sociological ambitions, however, stand out above these films, they are knowledgeable and insightful but their range is only local. There are some exceptional cases that overthrow this rule, such as Moving a Settlement or The Roma King (dir. Viliam Poltikovič). On the other hand, the superproductions such as Koza (dir. Ivan Ostrochovský) or The Queen of Silence (dir. Agnieszka Zwiefka) mainly concentrate on the formal side at the expense of the simplification of the film's content. My purpose is to present various variants of the representation of Roma conflict in these films.
\end{abstract}

Keywords: Roma, Central Europe, film, politics

"Roma Issue" has progressed to become one of the most serious areas related to Central Europe since the beginning of 1990s. The time of political transformation has created a new context for the issue present in the collective consciousness for many decades. This context is connected to an assumption about a contemporary solidifying of conflicts resulting from ethnic diversities. I am stressing the position of Piotr Balcerowicz who has tried to destroy two myths related to this matter: The first one claims that the number of ethnic conflicts has been rising steadily in the world, especially in the last decades, while the second one claims that the reasons for ethnic conflicts lie in ethnic, religious or cultural differences. ${ }^{1}$

1 Piotr Balcerowicz, "Czy istnieją konflikty etniczne i religijne?” (“Do Ethnic and Religious Conflicts Exist?”), in: Zaawansowane zapobieganie konfliktom [Advanced Conflict Prevention], ed. Wojciech Kostecki (Warsaw: Katedra Stosunków Międzynarodowych, Szkoła Wyższa Psychologii Społecznej, 2011), pp. 29-62. http://www.balcerowicz.eu/ texts/konflikty_etniczne.pdf. 
The author notes a discrepancy in judgment, which he elaborates in the following way:

(...) the conclusion that it is difficult to explain a distinct increase in the number of ethnic conflicts in recent decades is problematic in view of the feelings expressed by the Western World, who, following the ideas and representations created by the superficially educated representatives of mass media and politicians (at least in the area of methodology indispensable to the conflict analysis or the analysis of intercultural relations), or in view of a schematic assessment of empirical data - are convinced that the most recent several years have brought a virtual wave of threats to which we have to ascribe the conflicts of religious and ethnic nature. ${ }^{2}$

These "common feelings" are influenced by visual representations (media, film among others) that change with time. It is important to note that media influence the shape of representations of ethnic and national minorities but not everyday encounters with their representatives. Before 1989, Roma minority has not been shown in the context of conflict or confrontation in Central Europe (which is particularly interesting in view of the fact that conflict helps construct dramaturgy of a document by itself). Roma people were observed with curiosity through the prism of otherness and uniqueness. Well-known documentary films Before Leaves Fall (Zanim opadna liście, Władysław Ślesicki, Poland, 1964) and Gypsies (Cigányok, Sándor Sára, Hungary, 1963), and fiction films - Rosy Dreams (Ružové sny, Dušan Hanák, Slovakia, 1977) - attest to these claims. There were also propaganda documents (documentary film Upre Roma, Dimitrij Plichta, Slovakia, 1955), but the representations of Roma peoples were relatively varied because they were based on the direct observation of this minority through years of coexistence. For instance, the prohibition to migrate from place to place has become a pretext for immortalization of this Roma custom in the film Before Leaves Fall, which has become an important document of Roma people migrating in summer for the last time.

After years of coexistence under the conditions of Socialism, which functioned as a unifying factor for various social phenomena, even ethnic varieties, in 1989, there appeared political system changes whose consequences, especially rampant unemployment, touched Roma communities as well. ${ }^{3}$ In this context, we could

2 Balcerowicz, "Czy istnieją konflikty," p. 7.

3 "The reasons for the strengthening of this radical attitude within society are manifold, and I do not claim to propose an explanation for them. However, many researchers locate the origins of post-1989 anti-Roma sentiment in the forced assimilatory programs at the workplace under the Socialist regime, during which Roma were employed in unskilled positions of the lowest prestige and pay" Laszlo Strausz, "Producing prejudice: 
ask: Where do the causes of conflict with Roma people lie? It is worth remembering at this point that the genesis of these conflicts has always been associated with ethnic or religious diversity, which Balcerowicz divides into four categories: (1) Bad living conditions and extreme poverty, (2) repressive political system and especially the exclusion of some groups defined by their ethnicity, (3) destruction of natural resources and (4) cognitive dissonance. Another important factor leading to ethnic conflicts is a feeling of threat to the identity of the group. In reality, however, the four factors form a combination that includes number five as one of the four factors. ${ }^{4}$

During the process of political transformation, Roma people have seen their situation more acutely - they experienced a cognitive dissonance. ${ }^{5}$ At the same time, they learned how their communities lived in the Western countries. Their exodus, especially of Czech Roma people, to Canada has had far-reaching repercussions. Canada's refusal to grant these Roma people political asylum has been well known as well as the circumstances of Roma people return to Europe. ${ }^{6}$

"To sum it up: it is not ethnic, cultural or religious diversity as such which creates reasons for conflict, it becomes an element of the process of the rationalization of conflict at the basis of which lies a sense of injustice and harm." ${ }^{.7}$ This sense of injustice is one of the elements underlined by the protagonists of documentaries. Even if we assume that the number of conflicts has not grown - the certainty that Roma people have suffered past humiliations is constantly heard by the viewers of television programs.

The rhetoric of discourses in and around current films on Roma-Hungarian interethnic relations," Romani Studies: Journal of the Gypsy Lore Society, Vol. 24, No. 1 (2014), pp. 1-24.

4 Balcerowicz, “Czy istnieją konflikty,” p. 37.

5 Balcerowicz, "Czy istnieją konflikty," p. 38. "For decades, a specific group can live in extremely modest social conditions and be convinced that a possibility for change is very small or the change of these conditions is not objectively possible. As a result, what I see as a critical change/turning point, there comes a whirl of dramatic changes followed by a different view of the group on their own previous situation."

6 "Odchod Romu do Kanady," Kanada na vlastni oci (2000): 9 Jun. 2017, http://romove. radio.cz/cz/clanek/18731. Television NOVA has emitted a reportage within their program With My Own Eyes about carefree life of Czech Romas in Canada. Its message was: Roma people pack-up and come to Canada. Several hundred Roma from many Czech towns started selling their possessions in order to buy an air ticket behind the ocean.

7 Balcerowicz, "Czy istnieją konflikty," p. 40. 
Media and the film industries of V4 countries cannot ignore the opinions or be dismissive about local conflicts. It is not by mistake that the bloody attacks on Roma people took place during the economic crisis of 2008, which coincided with both the government and the financial ones. Very soon, the deeply touching films on this topic emerged such as a fictional film Just the Wind (Csak a szél, Benedek Fliegauf, 2012) or a documentary film Judgement in Hungary (Ittélet Magyarországon, Eszter Hajdú, 2013). I concentrate on these films because I am interested in a conflict shown from the inside with full understanding of its genesis, possible conditions and outcomes. The ambition of these films is to reveal that the conflict exists all the time while it remains hidden from view. Its explosion is potentially possible in view of the social conflicts present in a particular country. A proper recognition of the essence of these conflicts has been a crucial problem in recent years. The discourse about national minorities has been greatly tangled up in politics, the demonstration of which we see in film reviews as well. Such an entanglement is not conducive to the objectivity of expressed opinions. Neither is it conducive to noticing a universal conflict in the situation of national minorities' characteristic of any groups or individuals excluded or marginalized for any reason. Slovak film Gypsy (Cigán, Martin Šulik, 2011) is a good example of the presentation of one Roma boy in its universal aspect.

Among films illustrating spectacular conflicts, the documentary projects of the sociological ambition merit careful attention despite the fact that they reach only local audiences. Czech documentaries such as The Resettlement (Stěhováni osady, 1992) and The Roma King (Romský král, 2009), both made by Viliam Poltikovič, are remarkable examples as far as audiences are concerned. In general, sociological documentaries underline civilization conflicts existing at present but possible to be moderated.

I would also like to examine fiction films on the border between fiction and document such as Koza (dir. Ivan Ostrochovský, 2015) and The Queen of Silence (Królowa ciszy, Agnieszka Zwiefka, 2014) ${ }^{8}$ duly noted and rewarded both in their countries and abroad. It is worth asking, however, whether concentration on the formal aspects of the films does not take place at the expense of the simplification of content and the dismissal of the crux of the problem. Another question concerns the avoidance of conflict or even the creation of a supplementary conflict. Protagonists of the films employing these strategies become media celebrities because they have been allowed to shine in the framework of big cultural or sport

8 At the International Documentary Film Festival "Flahertiana” (Perm, Russia), the film was awarded Big Golden Nanook. 
projects, the process that does not solve their problems at all. The success goes to the creator of the film though.

\section{Latent conflict}

In the films devoted to the topic of Roma people, we can identify several ways of the presentation of conflicts. One of the most objective approaches is paying attention to the existing problems but absent from or eliminated from the present discourse and pushed into the subconsciousness. This intention is vivid in the film Just the Wind, ${ }^{9}$ which from the beginning of its production in political conflicts. ${ }^{10}$ Just this fact has been noted by critics:

"In Flieghauf's film it is the synergy between the actants who are invisible in the film like the wind and society whose representatives they feel they are, which is most frightening. The danger is more real the greater social permission for violence in society." 11

"The atmosphere of the omnipresent xenophobia fueled by the nationalist tirades of Orban, Prime Minister of Hungary, makes the concern that former murderers will be followed by enthusiastic copycats quite credible." 12

The film is quite exceptional in Hungarian cinema. According to Strausz, "Fliegauf's feature bonds the viewer first visually, and as a result, emotionally, with the Roma victims; a characteristic seen rarely in Hungarian fiction films."13

Just the Wind reveals the present state and possible consequences, conflicts and threat unceasingly hanging in the air. As Strausz sees it, "Thus, the central dramatic question of the film - when will the attack against the family take place keeps audiences at the edge of their seats. It is obvious that the assault will happen,

9 The film refers to the events from 2008/2009 when six Roma people were murdered in Hungary.

10 Strausz, "Producing prejudice," p. 3. "The premiere of the film in Berlin triggered a remarkable reaction by the Hungarian authorities (Ministry of Public Administration and Justice), which partially financed the production. At the press-showing of the film on February 16, 2012, the Ministry distributed a leaflet that suggested to the reporters and journalists how to interpret the film."

11 Adam Kruk, "To tylko wiatr/It is only Wind" Benedek Fliegauf (2012): 11 Aug. 2016, http://www.dwutygodnik.com/artykul/4158-to-tylko-wiatr-rez-benedek-fliegauf.html.

12 Piotr Czerkawski, "To tylko wiatr - produkt cynicznie skalkulowany" [It is Only a Wind - a cynically calculated product] (2012): 13 Jul. 2016, http://film.dziennik.pl/ recenzje/artykuly/412867,to-tylko-wiatr-recenzja.html.

13 Strausz, "Producing prejudice," p. 8-9. 
and the alignment of the audience with members of the family results in an effect of suspense, withholding information about the already suspected outcome." ${ }^{14}$

The atmosphere of fear is presented in an incredibly suggestive manner due to the construction of the film in a convention of a thriller. The director states that, "the perspective of the camera is taken directly from nature films. When (...) Attenborough tells about animals, he usually concentrates on those who are victims. The camera is not a weapon by itself - it only follows the protagonists under threat, and observes fear against the beast which may appear soon." 15

In the case of this particular film, the attitude to the topic, the awareness of the historical content, the expert preparation of the film content but also its final rejection function towards the presentation of an individual human drama. As Felis notes:

It is impossible to look at the murders and attacks as if it were a situation isolated from its context. What happened is closely related to the history of Roma people in Europe and Hungary accompanied by a long history of xenophobia and nationalist aggression, pseudo tolerance, mental prejudices and racial stereotypes. I have read numerous books, essays and articles about these issues but, at a certain moment, I had to discard this knowledge, reset mentally and concentrate on an individual human drama. Only this kind of drama can function in cinema, after all. ${ }^{16}$

According to Strausz, "Fliegauf's film thereby constructs positive character engagement by allowing audiences to consecutively move through the phases of recognition, alignment and allegiance bonding them with Roma protagonists." ${ }^{17}$

What does the director pay attention to, and what was impossible to be shown in the film? Exactly this hidden conflict that waits half-asleep to burst out at the end. The film convention did not allow for the conflict to burst out openly, although it is precisely this conflict that stays in the spectators' memory. There was no space in the film to reveal the roots of what took place in contemporary times in the middle of Europe. Fliegauf openly states:

The characteristic of racist, religious and xenophobic prejudices is such that they function well when hidden from view. They rule in language use, jokes in the context where seemingly they do not harm anyone. However, it takes only a spark for them to burst into flame, Hungary and Poland being clear examples of that. One should hear what people

14 Strausz, "Producing prejudice," p. 20.

15 Paweł T. Felis, "Film To tylko wiatr o atakach na węgierskich Romów. Tańczymy na beczce prochu" [It is only a wind about attacks on Hungarian Roma. We dance on the powder keg] Wyborcza.pl (2012): 13 Jul. 2016.

16 Felis, "Film To tylko wiatr."

17 Strausz, "Producing prejudice," p. 21. 
in different parts of the world say about my film after screening. It is necessary to travel around cities, small towns and villages, in so called "civilized" European countries to experience the level of contamination with stereotypical, racist and totally nationalistic thinking which is truly striking and horrifying today. It seems that we are all dancing on a powder keg not knowing about it. ${ }^{18}$

Despite all the criticism, Just the Wind is an excellent example of a film that sensitizes its audiences to the threats present in contemporary times, the threats that result from confrontations and reveal their dimension. Just the Wind is often compared to the film Gypsy by Šlík the director who shows greater understanding for the specificity of the culture of Roma people than Fliegauf. ${ }^{19}$ The director and the screenwriter of the film from Slovakia have concluded that the worlds of Roma and the world of "white people" do not differ that much after all:

We did not want to mythologise, folklorise or romanticise Roma people. We wanted to show their lives in a natural way because life in a Roma settlement mirrors our world. The only difference lies in intensity: everything is more emotional, sharper and more instantaneous. ${ }^{20}$

\section{Universal conflict}

Gypsy has a universal message as it tells the story of a man in an uncomfortable existential situation. In settlements in eastern Slovakia, their problem is not of national nature but rather of social nature. It is a problem of misery, lack of education and poverty, says the film director. Ghettoes emerge as they do in every other part of the world as marginalized societies reflect on the value system in every country.

"Of course, a ghetto creates its own, tough principles. Poverty and hunger have never formed good people. The survival instinct often forces people to break the law. Adam, the main character in our film, is similar to any other young member of society who struggles to live one's life. Inside, he does not agree with the world

18 Felis, "Film To tylko wiatr."

19 Piotr Czerkawski, "Publicystyka przebrana za sztukę - recenzja To tylko wiatr," [Journalism in the disguise of art. A film review of It is only a Wind] Cinemaenchante (2012): 13 Jul. 2016, http://cinemaenchante.blogspot.hu/2012/12/publicystyka-prze brana-za-sztuke.html.

20 [without the author] "Rozhovor s Martinom Šulíkom a Markom Leščákom" (2011): 20 Aug. 2016, http://www.ceskatelevize.cz/porady/10368608938-cigan/211 51212083/5130-martin-sulik-a-marek-lescak/. 
he sees around him but it is very difficult to find another way. He faces not only difficult social conditions but also the deformed ghetto rules." 21

This film, played in Roma language and with Roma actors, is part and parcel of the Slovak film tradition while it simultaneously enriches it. The Slovak film tradition implied wandering all over Slovakia in search of heroes, realistic locations and local customs. No theaters were avoided, including amateur theaters, schools, folklore sing-and-dance groups nor the artistic interest groups. Šulík states that this kind of work included another system of engagement with social groups based on establishing contacts, joining the group for a cup of coffee, getting to know who has been born, who died and who was arrested and learning about the incredible wealth of social levels at which Roma people function. The author shares with us a story of bricklayers who were never paid for their effort after finishing the job; he also tells us a story of a girl who was sold three times by her parents and who left her owners and studies now. The director knows more about Roma than he showed in his film. Thanks to this kind of approach, there is no feeling of artificiality or lack of adequacy in the means used in the film. The knowledge of Roma reality does not exclude the magic of visuals ${ }^{22}$ while the universalism of experience is an obvious good characteristic of the film.

\section{Civilization conflict}

Under the framework of the Czech group, Film and Sociology, ${ }^{23}$ two documents, The Resettlement and The Roma King by Poltikovič, have been created. The starting point for the story in the first film was the resettlement of Roma people to condominium blocks, the matter of particular interest from the sociological point of view. The film is not only about complex ethnic relations but also about political decisions. The decision about the construction of these condominiums was taken during the time of socialism and signaled the central solution to social problems. The construction project was finished but Roma people suffered from unemployment, a predicament more pervasive in the case of Roma than in the case of Czechs and Slovaks. The Roma King constitutes an extension of The Resettlement. Thanks to

21 "Rozhovor s Martinom Šulíkom a Markom Leščákom."

22 The film has been accepted by Roma themselves, which I experienced personally participating in the film screening for Roma people in their own natural environment nearby Roma settlements.

23 The activities of F\&S was the subject of my book: Jadwiga Głowa, Film Documentary in the Epoch of Havel (Krakow: Rabid, 2005). I refer to one of the films discussed in that book. 
the use of archival material, we witness a certain process. The starting point is the present time in poor settlements. The way media wrote about the film resembled an embellished advertisement of a fictional emigration office:

The more ambitious and diligent Roma people leave for England where they find a new and noble life; the traditionally cosmopolitan society accepts them and they can live better lives there. There is also another factor which is important for seemingly unresolvable situation of Roma. The missionaries of new Christian churches (...) managed to convince Roma people that God is everywhere, and, if they do not want to go to Hell after death but to Heaven, to Jesus, then they have to follow his path and abide by his rules. The transformation of thousands of Roma people is unbelievable - the end of alcoholism, crime, usury, promiscuity and violence. They start new healthy and peaceful lives. ${ }^{24}$

Religious motivation is really important in Romas' transformation. The film reveals the enormous civilization difference between the settlements in Spisz where living conditions are tragic and unemployment reaches 100 percent and those in cosmopolitan Sheffield where the happy migrants from Slovakia have landed.

Sequences in England were shot only during three days; however, it was possible to show not only this precipice but also the way it has been overcome. Key here is the statement of one of the protagonists. He proudly states that he has gained trust in his workplace. His behavior in front of the camera, the mimic of his face clearly attest to the fact that an opinion of an honest and reliable man is so valuable to him that he will not allow anybody to take it away from him. This is a value he never counted on. His career proves that in civilized conditions Roma can change their most established features and habits, the ones normally attributed to Roma. Because they are used to doing occasional jobs, they have not been used to systematicity, planning and thinking about tomorrow. However, when the stake is respect from Sheffield citizens, they conclude their efforts are worth it. The positive message of the film consists in the fact that the changes for the better have been shown, the changes that took place in a relatively short time.

\section{Avoidance of conflict}

Avoidance of conflict is a strategy seen in the films about "excluded people," especially when the cause of this exclusion is poverty. The unemployed, homeless and orphaned children, for instance, are covered by programs that get them out of poverty and humiliation for a short and spectacular time.

24 [Press Release] “Televizní premiéra filmu Romský král” (2009): 20 Aug. 2016, http:// romove.radio.cz/cz/clanek/22327. 
The unemployed play international matches for instance and children have their dreams come true. For a short time they live with success or they are condemned to their fate in the film. The film Koza (A Goat, 2015) made by Ostrochovský includes many elements from reality. The main hero plays himself when he takes part in a story made up by the screenwriters. ${ }^{25}$

Peter Baláž is the eight-time winner master of boxing in Slovakia who represented his country at the Olympic Games in Atlanta in 1996. Today he lives in a modest apartment, he gets half of the disability pension and he supplements his income with gathering scrap metal and delivering it to the scrap yard. The additional sources of income are ring boxing matches more or less once a month because he is not strong enough to perform more often than that. In the film, he is shown participating in an intense international boxing tourney in order to earn money because his life partner is pregnant and would like to abort the baby while he would like to save it. Anyway, he faces a challenge of proving that he is responsible for the family. The abortion dilemma has been probably created by film screenwriters but the director's discussion of it is questionable as not really compatible with reality. Roma woman, Peter's partner who lives in quite tolerable conditions, tries to abort the second child? The reasons for such a decision have not been shown in a credible way as Tomáš Hučko offers. ${ }^{26}$ In his opinion, dilemmas and paradoxes of the main hero situation required the presentation of a realistic social background. However, all the details and social specificities have been discarded as they did not contribute to the plot development while the colorful details and the social environment characteristics are particularly valuable in the case of this particular story. Baláž fights at local boxing matches somewhere in Austria or Germany. Unfortunately, the director has not revealed the realities of similar boxing matches, the reaction of the public, neither did the director show the relations between spectators and the gradually weakening boxer, in other words, the minimalist aesthetics prevented the development of the topic or exposed its specific dynamics. The minimalism of means of presentation, the lack of emotion, coldness and restraint, sophisticated shots and the preference for contemplation led to an almost manneristic effect that resulted in the indifference of the spectator who is left to admire the perfection of the minimalist construction.

The admiration for the construction of the film far from minimalism is profound in the reception of the film The Queen of Silence by Agnieszka Zwiefka.

25 Tomáš Hučko, "Minimalizmus, ktorý aj v hrubej dokumentárnej vrstve osekal ozajstný život" [The minimalism that cuts down real life even in the rough documentary], Dokofilm (2015): 9 Sep. 2016, http://dokofilm.sk/filmy/koza/.

26 Hučko, "Minimalizmus." 
The film is classified as documentary portraying illegal Roma inhabitants of the camp near Wroclaw in which they have lived for over twenty years. Despite long contact with her protagonists and despite her own feeling of exclusion experienced during her former stay in the United States of America, the director clearly colors the film plot, which she justifies in the following way:

These children are truly happy. When I observed them, I was under the impression that they are much happier than the Polish ones who live in clean houses in which there is always warm food on the table. Polish kids, however, do not express this joy and love for life which Roma children do (...) we did not want to make an objective film of the social intervention reportage type. This was supposed to be a film about Roma community from the point of view ten-year-old Denisa. This is why the fairy tale aspect was so important. ${ }^{27}$

The purpose of the director was to deliberately avoid the classical form of reportage that she realized earlier: "I am no longer interested in the classical form of documentary when an interviewee sits and responds to your questions for twenty minutes. Everything is sad, nothing happens and everything is gray and dark (...) I am aware of the fact that this film is somewhere on the border between genres and is a kind of a genre hybrid. Alas, am I to make another sad film about Roma? Nobody would be able to endure it, nobody would be interested." 28

Showing the world from the position of a child and obvious inspirations from Bollywood cinema were criticized in press. "How come a deaf girl can dance to music? Well, it is pure guesswork. Denisa loves all the encasement of Bollywood films - colorful clothes, gadgets and sequins." ${ }^{29}$

Musical scenes, combining documentary with fiction film, a kind of genre hybrid drew critics' and spectators' attention to a greater degree than the film topic itself. It became an epitomization of a specific artiste's syndrome. In television practice in Central Europe, a solid reportage seems too banal, not in esteem and in its process of production is devoted too little time and money for its realization. On the other hand, a musical documentary has a chance to gain interest from co-producers interested in the international response to the film.

27 Katarzyna Nowakowska, "Agnieszka Zwiefka: Gdy oznajmiłam wrocławskim Romom, że chcę nakręcić o nich film, mówili o mnie "dili", co znaczy szalona," Gazeta. pl. (2016): 23 Aug. 2016, http://weekend.gazeta.pl/weekend/1,152121,17075984,Agni eszka_Zwiefka_Gdy_oznajmilam_wroclawskim_Romom_html.

28 Nowakowska, "Agnieszka Zwiefka." The film author adds in the cited interview that the comparison of her document with the films of Kusturica was the greatest honor to her.

29 Mateusz Madejski, "Królowa ciszy: Bollywoodzki dokument z Wrocławia" (2014): 2 Sep. 2016, http://www.serialowa.pl/87979/krolowa-ciszy-bollywoodzki-dokumentzwroclawia/. 


\section{Surrogate conflict}

Some documents may become questionable, especially the ones the plot of which is based on exceptional action, a mission probably planned for the film by the screenwriters. An example of such a film is Back Passing (Malá domov by Jaro Vojtek, 2008), which tells the story of David who wants to take part in an international football tourney in Serbia. A mixed football team is composed of Slovak and Roma boys. The trainer Roma Vlado Sendrei has gathered this team and even included boys from correction facilities. The spectator cheers on the young Roma boy who is about to be accepted for the team and hopes that everything goes well. Despite the fact that we may doubt the authenticity of some events, we observe with interest what has happened during the team's stay abroad. Has the mobile phone really been lost to justify shooting of a scene expecting its return? There is also another more important question to answer: has this trip changed anything in the lives of protagonists "rented out" from correction facilities for a moment?

An optimal project in the context of the earlier-mentioned documentary is the film Tititá (Tititá, dir. Tamás Almási, 2015). It tells a story of a boy coming from a Roma settlement who got a chance to participate in a musical workshop. The long and laborious process of education, exercises and rehearsals during which the protagonist realizes that he is not good enough to perform has been perfectly depicted. The protagonist lacks basic skills and cannot cover the distance between himself and other participants of the workshop. In an act of self-defense, he escapes into illness, bad moods, and he shuts himself in. When he leaves for a short stay to his family settlement, he sees it in a different light. It comes to him that he will never have the conditions there to practice guitar play. With his skills, he will only be able to play to dance at the local festivities.

Taking all the political correctness rules into consideration, we are talking here about establishing a space for an average Roma person who has talent, but not as much talent as he needs to be truly successful in the music world. If he started practicing guitar playing when he was a three-year-old child, who knows who he would be today. At present, he can teach music beginners at most, so the chance for success passes on to the next generation. The conflict exists but is not spectacular. In the presented scale, it cannot impact viewers' emotions, there is no great drama in the film or big wins, neither are tragedies particularly spectacular. The value of this documentary lies in prolonged observation - only then are acclimatization difficulties of the protagonist well seen as is the awareness of the loss more explicit. In Back Passing, we observe a single "success" of David, in Tititá, the causes of defeat of a nineteen-year-old Antal Kuru for whom it is too late to realize his dreams. He cannot have spectacular action without arduous process. 
In my chapter, I have discussed the films of the directors from Central Europe. The Western perspective is also valid as long as one does not assume one fixed position. In my opinion, Western directors do not go deep into the analysis of the causes of conflicts while practicing political correctness that does not bring them closer to truth. There is a gulf between political correctness and reality, to which no proper terms are adaptable. In the case of Roma topic, there is danger of romanticizing and poeticization, especially concerning the past. This poeticization is the merit of non-Roma creators because in Roma culture, the question of historical memory is highly questionable. Coloring of the nomadic past is also a creation of the cinema as we absorb (both creators and spectators) this enchanting vision. The problem arises when we project this vision at the present and the future. Then we show an ideal reality whereby the cultural "otherness" is realized surprisingly in accord with the requirements of the contemporary world. The wishful thinking despite appearances has this negative effect that it pushes Roma people to the margin as the bureaucratized civilization needs a colorful embellishment (talented Roma musicians, for instance) that does not surpass the arranged framework.

\section{Bibliography}

Balcerowicz, Piotr. "Czy istnieją konflikty etniczne i religijne?" ("Do Ethnic and Religious Conflicts Exist?") In: Zaawansowane zapobieganie konfliktom (Advanced Conflict Prevention), ed. Wojciech Kostecki. Warszawa: Katedra Stosunków Międzynarodowych, Szkoła Wyższa Psychologii Społecznej, 2011, pp. 29-62.

Czerkawski, Piotr. “To tylko wiatr - produkt cynicznie skalkulowany." 2012. http://film.dziennik.pl/recenzje/artykuly/412867,to-tylko-wiatr-recenzja.html (13 Jul. 2016)

Czerkawski, Piotr, "Publicystyka przebrana za sztukę - recenzja To tylko wiatr Benedeka Fliegaufa." 2012. http://cinemaenchante.blogspot.hu/2012/12/pub licystyka-przebrana-za-sztuke.html (13. Jul. 2016)

Felis, Paweł T. "Film “To tylko wiatr” o atakach na węgierskich Romów. Tańczymy na beczce prochu." 2012. http://wyborcza.pl/1,75410,13019686,Film To_tylko_wiatr_o_atakach_na_wegierskich_Romow_html (26 Sep. 2017)

Głowa, Jadwiga. Dokument filmowy epoki Havla. Kraków: Rabid, 2005.

Hučko, Tomáš. "Minimalizmus, ktorý aj v hrubej dokumentárnej vrstve osekal ozajstný život.” 2015. http://dokofilm.sk/filmy/koza/ (9 Sep. 2016) 
Kruk, Adam. “To tylko wiatr, Reż. Benedek Fliegauf.” 2012. http://www.dwu tygodnik.com/artykul/4158-to-tylko-wiatr-rez-benedek-fliegauf.html (11 Aug. 2016)

Madejski, Mateusz. “Królowa ciszy: Bollywoodzki dokument z Wrocławia.” 2014. http://www.serialowa.pl/87979/krolowa-ciszy-bollywoodzki-dokumentzwroclawia/ (2 Sep. 2016)

Nowakowska, Katarzyna. "Agnieszka Zwiefka: Gdy oznajmiłam wrocławskim Romom, że chcę nakręcić o nich film, mówili o mnie “dili”, co znaczy szalona.” http://weekend.gazeta.pl/weekend/1,152121,17075984,Agnieszka_Zwiefka_ Gdy_oznajmilam_wroclawskim_Romom_.html (23 Aug. 2016)

“Odchod Romu do Kanady." 2000. http://romove.radio.cz/cz/clanek/18731 (9 Jun. 2017)

"Rozhovor s Martinom Šulíkom a Markom Leščákom". http://www.ceskatelevize. cz/porady/10368608938-cigan/21151212083/5130-martin-sulik-a-mareklescak/ (20 Aug. 2016)

Strausz, Laszlo. "Producing prejudice: The rhetoric of discourses in and around current films on Roma-Hungarian interethnic relations." Romani Studies: Journal of the Gypsy Lore Society, Vol. 24, 2014, pp. 1-24.

“Televizní premiéra filmu Romský král." Press release 14 Apr. 2009. http://romove. radio.cz/cz/clanek/22327 (20 Aug. 2016) 


\title{
Iwona Grodź
}

\section{Stereotypes and attempts at challenging them in Papusza (2013) by Krzysztof Krauze and Joanna Kos-Krauze}

\begin{abstract}
The chapter discusses the matter of stereotypes, antagonisms and all kinds of intolerance towards ethnic minorities in Poland. The research material is the Romani minority in Krzysztof Krauze and Joanna Kos-Krauze's Papusza (2013). The analysis begins with the interest in social problems, or "conflicts and controversies - divisive for contemporary societies." The subject of the analysis is the Romani minority and the attitude of the Polish society towards it. Stereotypes which bring about negative emotions and prejudices are followed by clearly discriminatory behaviour. The end point shall be a diagnosis of the manner in which Polish cinema challenges mental stereotypes of ethnicity.
\end{abstract}

Keywords: Stereotypes, Romani minority, Krzysztof Krauze, film Papusza (2013).

In the forest I grew like a shrub of gold, born in a Gypsy tent, akin to a boletus. I love fire like my own heart. The winds lesser and greater cradled the little Gypsy and blew her far away into the world...

Papusza, Pieśń cygańska z Papuszy głowy ułożona [Gypsy song taken from Papusza’s Head]

"Can we understand other peoples' cultures in the way they understand them?" "Must this understanding be distorted as it is transferred through the prism of our understanding?" "The troubles that occur between genders are similar to those that affect communication between two different cultures?" "Why are some cultures and cultural forms more appreciated than others?" These are just several issues that may arise when analysing the topic of stereotypes and attempts at breaking them in the Polish cinema.

Krzysztof Krauze and Joanna Kos-Krauze's Papusza from $2013^{1}$ brings forth several perspectives into discussion in this context:

* Translation by Agnieszka Marciniak, Iwona Grodź.

1 See also two documents about the poet: Papusza, dir. M. Wójcik (1974) and The History of the Gypsy, dir. G. Kowalski (1991). 
a) Sociological - the main point of interest will be the relation between Poles and Romani minority as portrayed in the film. The most important topics include the forced settlements and "adjusting" the Roma to life in the Polish society; the problem of inequality (here: poverty) and subsequent conflicts or alienation; the stereotypical attitude to the Roma hidden even in the language - in the words such as the Gypsy or the Roma. The former (in Polish: Cygan), although most often used, raises a lot of negative associations, as it invokes an image of a liar and thief. The latter, although politically correct, is not so widely spread and is negated even by the Gypsies themselves. Edward Dębicki said about himself: "I am a Gypsy, and my grandfather was a Gypsy. I am no Roma! The word simply means a Gypsy in our language. For God's sake! We cannot escape our history! [...]." Further, Karol Gierliński, a poet and sculptor, believes that the word "Roma" is in Polish an artificial name created in the media ${ }^{2}$. My conclusion is as follows: a change in the nomenclature is significant when it proves that the way of thinking had changed. When it is only enforced by the correctness, it does not bring anything new. All the interested parties - including the bearers of a given name - know that ${ }^{3}$.

b) Feminist - the centre of attention will be the way in which women are presented and functioning in the Romani society, what roles are attributed to

2 See Angelika Kuźniak, Papusza (Wołowiec: Czarne, 2013), p. 190. See also Magdalena Machowska, Bronisława Wajs - Papusza. Między biografia a legenda [Bronisława Wajs Papusza. Between a biography and a legend] (Kraków: Nomos, 2011), p. 26. In the part devoted to Objaśnienie terminów Cygan, Rom [Explanation of Terminology Gypsy, Roma], Machowska explains that she uses the first form (in Polish: Cygan translator's note) since it appears in documents forming the basis for her work. Papusza called herself a Gypsy (Cyganka) as well. Moreover, the word Gypsy has a wider meaning than Roma. On the other hand, the aspect of political correctness is also important. Namely, as Machowska wrote: "In the view of the Roma the word Roma does not strip them of dignity and respect, since it creates a new context and gives a chance for dialogue in which the Roma's story about themselves will be shared from a partner's and not just subject's perspective. Thus, they gain a chance to build a new identity. Certainly, however, it diminishes the distance towards the Gypsy community. The improvement of their image must come through education and not through changing names, and such cognitive and educational aims are set out by this book and an academic paper on Gypsies."

3 The fundamental notions that are helpful in understanding this viewpoint on the story portrayed in the film will be: the power and surveillance, habitus, inequality, the concept of "the culture of poverty," theory of "the vicious circle of deficiency," appearance of people outside of social classes, topographies of culture and their cultural images (villages, towns, cities), nomadic cultures, community and alienation (expulsion). 
them in childhood, adolescence (quick marriages) and above all in marriage (listening to and serving the husband) and what changes are occurring ${ }^{4}$.

One of the first researchers into the history and culture of Polish Roma, aiming at changing its image and popularising knowledge, was Jerzy Ficowski ${ }^{5}$. Further, Lech Mróz and Ryszard Tomicki would write on the history of Roma as well. The former noted that "[a]mong ethnic groups living in Poland for centuries, the Romani constitute the most exotic and intriguing element, least known to their neighbours and folklore researchers. Their clans and families are communities closed to the outside world and cultivating their own traditional customs, they are governed by their own laws and communicate in a language known only to them and unwritten. They do not allow outsiders to learn the secrets of their existence"6. The author of The Polish Roma wrote in his Introduction that the "firmly established animosities" and feeling of foreignness or aversion towards the Gypsies all result from speculations. They are thought to be "demonic" due to occupying themselves with divination, "criminal" as they are suspected of thievery and "operetta-like" since they are thought to be romantic, to love nature and play. The aim of the book is, however, to change the image and perception of the Roma by telling their stories and replacing imagery with rationalism ${ }^{7}$.

4 An appropriate context here is the representation of femininity in the Roma culture as well as the paradoxes of female modesty, duplicity, visibility, beauty or death.

5 Jerzy Ficowski, Cyganie w Polsce. Dzieje i obyczaje [The Romani in Poland] (Warszawa: PIW, 1953).

6 Jerzy Ficowski, Cyganie, pp. 8-9.

7 See also Lech Mróz, Ryszard Tomicki, “Jak Cyganie świat zdobyli ... Kilka uwag, kilka pytań, kilka refleksji” [How the Roma conquered the world ... Some notes, questions and reflections], in: Antropolog wobec współczesności, eds. Anna Malewska-Szałygin, Magdalena Radkowska-Walkowicz (Warszawa: UW, 2010), pp. 293-317. The authors analyse how the Roma arrived not only in Europe, but also in Africa, Asia, America and even Australia. "In Europe, the Gypsies created clan and regional communities, as well as international ones. In the 1970s a new community layer was born, the intelligentsia of political leaders, social workers and artists. The Gypsies began to fight for their rights and dignity. Political correctness led to them being called Roma, even though they themselves did not accept such a name. The European Union allowed for the Gypsies to become fully fledged citizens of countries where they lived, with the idea of ex-territorial nation. The Gypsies began to discover Europe and history once again, by separating truth and legend. Source literature claims that "in the arising ethnic mythology, the origins of Gypsies are rooted in India and connected to the Kshatriya social class. But what really connects them is their ancient nomadic lifestyle." 
The uniqueness of Papusza consists in the fact that, as Ficowski wrote, "the Gypsy song exists as a work of nameless folk culture, but we have never known a conscious Gypsy author and praiser of camping tabors (settlements), someone whose name would be known and saved in the collective memory. Not for the five hundred years of Gypsy wandering through Poland". The oral tradition is evanescent, improvised and anonymous. It was not favourable towards permanent presence of Gypsy folk songs in people's memory9.

Papusza is the first Gypsy poet with firm presence in the public space. Angelika Kuźniak wrote that " $\mathrm{t}]$ he possibility of having her words written down stripped Papusza of her unrestrained freedom of vocal improvisation with accompanying music - which gave wings to imagination, her words and phrases. The limited ability to write was for Papusza to a certain extent an unwanted barrier, as it did not always lead to correct choice of words or appropriateness of means of expression. (...) Despite such difficulties (...) the poems are not only a precious document, but also a work of art - no longer nameless, yet still bearing the features of folk art and 'primitive' freshness"10.

Poetic and vocal improvisation was the characteristic form of Gypsy art. It was a folk recitation to music, covering subjects such as death, mourning, freedom and loss of freedom, and the nomadic lifestyle. Only a few folklorists managed to record the ephemeral works via taping of Gypsy songs or artistic shows ${ }^{11}$.

\section{The social issues in the film Papusza}

Researchers of social issues indicate six main areas of conflicts and compromises, or in other words, of relations laden with social tension: gender (subordination, feminist perspective, etc.), race (racism), nationality, religion, social class (poverty and contempt) and age (youth and old age).

8 Jerzy Ficowski, “Wstęp” [Introduction], in: Papusza, Lesie, ojcze mój (Warszawa: Nisza, 2013), p. 7.

9 See for example the new edition e-book Teodor Narbutt, Rys historyczny ludu cygańskiego [Gypsy People: A Historical Outline] (Warszawa: Imprint, 2010).

10 Jerzy Ficowski, “Wstęp," p. 9. Ficowski mentions Gypsy poets from other countries, but judges them to be professionals and not "naive poets" such as Papusza. They include Bari Karoly from Hungary and Rajko Burin from Yugoslavia.

11 In the margin, it must be added that the music for the film was composed by wellknown Polish composer Jan Kanty-Pawluśkiewicz (born 1942), who has no Roma roots. It is a clear signal that the directors wanted to emphasise the versatility of their film, in the sound layer of Papusza, to combine, not to divide. 
For years, the nomadic lifestyle was the most interesting characteristics of the Romani. It was considered the most intriguing. The reasons for beginning to wander and various motivations and consequences of it were thoroughly analysed. The history of the ethnic group ought to be the starting point.

Linguistic research has proven that the Romani language is similar to languages in the Indo-European group, which allowed for speculations that the Romani come from India ${ }^{12}$. However, the history is much more complicated and full of gaps, ambiguities and assumptions, as Lech Mróz and Ryszard Tomicki claim in the subchapter Exodus and expansion of their previously mentioned work. As regards Poland, the earliest traces of the Roma come from 1401 and the town log book of Kazimierz in Cracow, where a taxpayer Matiasz Cygan was mentioned ${ }^{13}$. Interestingly, the Roma were very familiar with biblical stories, despite their lack of education. Mróz and Tomicki also indicate that the Roma used safe conduct documents issued by popes and kings (including Sigismund I the Old).

Stereotypes concerning perception of Roma in Poland have been around for long; not often, however, do they become the content of artistic undertakings in the Gypsy community. Papusza was a person who not only saw the disdain towards her social and ethnic group, but was also able to talk about it. Hence, probably, her words that have become the motto to Angelika Kuźniak's study, Papusza: "I come not to you for your money, (...) I come to you so that you don't make a black night of a white day"14.

An important event was also the decision of the Ministry for Public Administration concerning "the settlement and activisation of the Gypsy population" of $1950^{15}$. Through a conference organised in Warsaw, Papusza and her husband were also involved in the action. In contrast to other Romas, the poet believed that such activities would contribute to their good. She tried to argue with others and convince them. In 1950, Papusza even wrote a poem on the topic, entitled Na dobrej drodze (Pre laćcho drom/On the right road) ${ }^{16}$.

12 Lech Mróz, Ryszard Tomicki, “Jak Cyganie świat zdobyli,” p. 295.

13 Lech Mróz, Ryszard Tomicki, “Jak Cyganie świat zdobyli,” p. 298.

14 Words of Papusza as quoted in Angelika Kuźniak, Papusza, p. 7.

15 Angelika Kuźniak, Papusza, p. 91.

16 Papusza, "Na dobrej drodze," in: Lesie, ojcze mój [Forest, My Father] (Warszawa: Nisza, 2013), pp. 46-47. 
Previously, as Papusza wrote, the Romas would be expelled to the forest "by other lords." There, "their hearts became like stone." That is why now they would be afraid of the change and miss the woods ${ }^{17}$.

Ficowski wrote that Papusza should not be considered a social didactic, even though she wrote some poems in favour of activisation of Gypsies ${ }^{18}$. These works are usually judged quite harshly. Moreover, the poet created them for specific financial benefits (allegedly, to be allotted housing).

In the Report on Aid and Activisation of the Gypsy People of 26 February 1951, we read that "[c]oncerning the settlement of Wajs's tabor of about 130 people, a conference with its representatives was held. After the five-person delegation learned more about the government's position, they expressed the willingness to settle the whole tabor in one of the towns near Wrocław. (...) Due to housing shortages and other unrealistic demands the group was not settled. According to other Roma, Wajs's group had not really wanted to settle, but just to see what was the position of central government towards the Roma people"19. There were many difficulties. It seems that they have not been overcome until today. The point was mainly to force the Roma to settle (via registration), undertake permanent jobs and send children to school - all in all, making them, in line with the popular slogan of the time, "fully-fledged citizens of the People's Republic of Poland."

Emancipation of the Roma brought about both positive and negative consequences. On the one hand, the group finally had a chance to become visible. On the other, new rules of living often ended in dramatic situations. Starting from 1964 (thirteen years after official announcements), the Roma were fully forbidden to lead a nomadic and migratory life. The elders believed that the prohibition was dangerous for their traditions and ethnic diversity. The process of assimilation and education, according to sceptical Romani, led to the disappearance of their language and culture. Papusza was a poet who predicted the change and the end. Ficowski calls her the "expression of common habits, attachments and yearnings which were the spiritus movens of her work" 20.

The aversion of the Roma towards Papusza came from their distrust in outsiders. By getting closer to someone from outside the community, the poet entered the path of treason. Hence, in the 1950s and onwards, she was prosecuted for her

17 Papusza, Lesie, ojcze, p. 30. In the poem entitled Na śladach ognisk grzyb wyrosty [Mushrooms have grown in old Gypsy bonfires] (Watry betkenca zabaryne), mushrooms, like old Gypsies or simply elderly people, die when uprooted.

18 Jerzy Ficowski, “Wstęp," p. 10.

19 Angelika Kuźniak, Papusza, pp. 95, 97, 128.

20 Jerzy Ficowski, “Wstęp," p. 11. 
friendship with Ficowski and other "Others." Disdain of the Roma contributed to her nervous disease, loneliness and unwillingness to continue writing. True, she was not fully expelled from the community due to her illness; in Gypsy circles such offenders were usually called famuło or infamis and simply disappeared due to magerdy or exclusion. Yet, close to the end of her life she wrote: "If I hadn't learned to read or write, maybe, me silly, I would have been happy"21. The poet could not have foreseen the opinions and reactions to her work. That is why in her case the old Gypsy proverb proved true: "Cut your tongue before your tongue cuts your head off." The question is, how did she start learning to read?

The future poet was born in 1909; some sources indicate 1908 or 1910. At that time, illiteracy was the norm among the Gypsies. Against the will of her parents and despite the anger of other Gypsies, she started to learn to read with a Jewish shopowner. Eagerness to learn and the approval (a compliment) from an elegant lady she met, made Papusza sure she wanted to continue. However, because of that she faced numerous challenges throughout her lifetime, and some Romani never accepted her education. When she died on 8 February 1987, the attitude of this ethnic group towards education was partly, although not radically, changed.

Understanding the mentality of the Roma is linked to learning more about their customs, perception and interpretation of the world. Only this allows for good practices within the so-called engaged culture. Romani dances, freedom and joy are just one side of the coin, the one shown to the world. Nowadays, it is associated with Cepelia and stereotypical presentation of cultural features of the group. One of Papusza's poems praising the dances is entitled Patrze tu, patrze tam (Dikchaw daj, dikchaw doj/I look here, I look there) of $1951^{22}$.

However, there is also the other side of the coin. It is symbolised by winter, which for ages has been the time of stopping and settling. In this season, the Roma would reminiscence about past travels, sing, chat and wait for the spring. They also felt most of the chill, poverty, hunger and alienation.

Settling down in one place was a necessity, in order to escape the poverty and disdain of the people. At the same time, it meant the loss of freedom, praised nostalgically in the memories of spring or summer wandering. Papusza wrote on the subject as well. We are also familiar with her biography. Before the war, she would wander mostly through Volhynia, Podolia and the Grodno area. After the war, she lived in Żagań, Gorzów Wielkopolski and Inowrocław. It is said that she

21 As quoted in Jerzy Ficowski, “Wstęp," p. 13.

22 Papusza, “Patrzę tu, patrzę tam," in: Papusza, Lesie, ojcze mój (Warszawa: Nisza), p. 48. 
dreamed about looking at trees, but the forest remained only a memory, similarly to rivers or green grass in May (cf. the poem In May) ${ }^{23}$.

\section{The feminist issues in the film Papusza}

In one of the interviews, Joanna Kos-Krauze stated that "[i]n Poland the attitude towards women is hypocritical. Yet, it is women who are the driving force behind economic development" ${ }^{\text {"24 }}$. Similar thinking is applied to female artists.

The status of women at the beginning of the twentieth century in Poland - and additionally, in a particular group - is a matter that may be raised when discussing the name of the main character. The secret of the unusual (illegible for Poles) name of the Gypsy poet is hidden in her mother's dreams and an exceptional ghost story.

The film reveals the former source. In the prologue, we see a pregnant woman looking dreamily at an elegantly dressed doll standing in a shop window. We arrive at the conclusion that the young Roma is fascinated not only by the doll, but also by the female world which it represents. The world is at the same time close and far away. It is close since it treats women mainly as beautiful decorations, but far away in the manner of showing or rather expressing this status of women. The bourgeoisie culture is connected with luxury and creation of at least the appearance of respect towards women - ladies. The Gypsy culture is quite open about reducing women to "toys," which are to be the source of entertainment, but also - paradoxically - mothers, housewives and simply physical workers. The double role is an additional burden on the shoulders of Gypsy women. Not all of them may enjoy the privilege of being only beautiful and rich.

Let us return to the ghost story: according to the legend, a ghost appears on the third night after a Gypsy child is born. It reveals what good and evil will come to the newborn; the same happened with Papusza. However, nobody ever wanted to reveal what had been forecast for the little girl. The secret has only been strengthened by the words which are also repeated in the film: "She will either bring us great pride, or great shame." At first, the girl was named Bronka, but she turned out to be so wonderful and beautiful that they began to call her "Precious." Finally, the girl received the nickname Papusza, which in the Romani language meant "doll."

23 Papusza, "Patrzę tu, patrzę tam."

24 Bożena Chodyniecka, "U nas faceci robili filmy tylko dla siebie" [Here, men would only make films for themselves], Dziennik Trybuna, Vol. 28-30 (2013), p. 16. 
In the Gypsy society, the family model is patriarchal, and the man “(...) may do whatever he thinks of to his wife"25. Hence the analysis of the feminist perspective and of female search for knowledge. Papusza knew the importance of education. Unfortunately, it was "evil" to be educated in her community, especially for a woman. The poet would say: "Without education, one has blind eyes. Mummy also did not know anything. I asked her to let me go to school. She didn't want to listen. So, I collected paper, sometimes pulled it out of garbage. And I painted with coal whatever I saw. Only not letters, because I didn't know them"26.

Young Papusza dreamed about learning to read, and that is why she quickly found an appropriate teacher. The Jewish shopowner received a chicken from the girl for each lesson. The mother did not like it, and she used to say: "The books are for nothing, the head gets poisoned with them. This is where stupidity comes from." Papusza's father hit her for studying, and other Roma are said to have spat on her and made fun of her ${ }^{27}$. The poet wrote about her dreams in $I$, the poor Gypsy, as she knew that Roma who do not describe their experiences will be forgotten. She, therefore, was writing in their name, in order to save the memory.

Finally, one should ask the question: "Is Papusza a feminist film?" The director has stated that it showed the helplessness of women in the system of oppression, which is similar to that experienced by ethnic minorities, including the Romani. Undoubtedly, it is the engaged cinema. Additionally, one should remember that relatively few films have been made on the subject of the Roma when deciding on the importance of Papusza. The topic was undertaken basically only by Emir Kusturica $^{28}$ and Tony Gatlif ${ }^{29}$, and in Poland by Dorota Kędzierzawska (on a margin of her feature film Diably, diabł ${ }^{30}$ ) and documentary filmmaker Władysław Ślesicki ${ }^{31}$. Hence, it is important to show that the Romani life is no fairy tale, no regional fair or traditional parade. In a metaphorical manner, the selection of black, white and a palette of grey for the film explains this reality. The Roma, just

25 Bożena Chodyniecka, "U nas faceci," p. 15.

26 Angelika Kuźniak, Papusza, p. 27.

27 Angelika Kuźniak, Papusza, p. 27.

28 Emir Kusturica - director, born in Sarajevo in 1954, his films include Dom za vešanje (1988), Underground (1995), Black cat, white cat (1998).

29 Tony Gatlif - director, born in Algiers in 1948, his films include Gadjo dilo (1997), Vengo (2000), Exils (2004), Transylvania (2006).

30 Dorota Kędzierzawska - Polish director, born in 1957.

31 Władysław Ślesicki (1927-2008) - Polish director of feature and documentary films which include Jedzie tabor (1955), Zanim opadna liście (1964). 
as in the film, still remain the "close strangers," similarly to women in oppressive systems, often limited by religion, politics or economy ${ }^{32}$.

\section{Conclusion}

Marian Golka noted that:

(...) art is not separate from the social life, but constitutes one of its elements or aspects. Of course, it is not the sublimation or the most important product of the social life, but also - it is not its margin. In its nature, art is social, just as societies are inherently cocreated by artworks, together with other cultural and natural influences. An artistic fact is a social fact; regardless of whether it is a purely social one. (...) Sociology is less useful for the examination of the work of art itself, more so for learning about its context. In art, we deal with a particular tangle of social values and means of expressing them, of content and form, of perception of the world and the manner in which the perception is articulated ${ }^{33}$.

Such attitude towards art ascribes it to the "engaged culture" area, which overcomes stereotypes and prevents conflicts. In line with that, the most important functions of artistic statements or performances are according to Golka:

a) "Modelling of social values" - this function consists of a number of minor functions: aesthetic, hedonist, therapeutic, expressive, communicative, magical, ideological, educational, cognitive and economic.

b) "Modelling of social ties" - this function consists in connecting people with similar experiences and values, in unification and ordering of the social structure. At the same time, it brings in differentiation and complicatedness, as it distinguishes between "Us" and "Them" ${ }^{4}$.

In the case of Papusza, almost all of these functions have been fulfilled. Film is a type of art directed at mass audiences. It may establish, sustain, model or explain both well-known and new values belonging to a different culture. It does that via

a) refined anaesthetisation and overly orderly manner of filming - Papusza is shot in black and white since the directors wanted to escape the artificial bling, cheap folklore and circus-like quality which is often associated with the Gypsy culture full of colourful dresses or gold. Even so, the artistic layer of the film is

32 Bożena Chodyniecka, "U nas faceci," p. 16. The issues mentioned here were also discussed during the Congress of Women or Women's Cinema Review, as mentioned by Joanna Kos-Krauze in the quoted interview.

33 Marian Golka, "Sztuka w socjologicznych ramach" [Art in the sociological framework], in: Socjologia sztuki, ed. Marian Golka (Warszawa: Difin, 2008), pp. 11-46.

34 Marian Golka, "Sztuka," pp. 200-227. 
refined due to precise framing and focus on lines and shapes, structures that determine the texture of scenography, and nuanced hues of grey. Ultimately, one may arrive at a paradoxical conclusion: the film is internally colourful with "hidden colours" within the black-and-white world. In order to see it, one needs to forget what is visible with the blind eye and delve deep into the reality.

b) the hedonist and therapeutic function of Papusza is brought about by joy experienced at certain (only few) moments in the film: when we see the Roma celebrating, playing, singing and dancing with joy at bonfires. Each time, the image is dusted over with internal and hidden sorrow, for instance, by the yearning of the little girl to learn, by reflection on poetry and writing, or contrariness in prison. The therapeutic qualities of Papusza consist mainly in separation from contemporary problems and reaching for the roots of the undertaken subjects. Understanding what is "the otherness" requires understanding its sources, since some perceive what is different as alien. Deeper insight into the image allows for recognition of one's own, often stereotypical, attitude.

c) the expressive function should present the position and emotions of the Krauze duo, senders of the artistic message. It consists of the cognitive and magical, as well as partly didactic, minor functions. The filmmakers bring the already non-existent world to life; hence, the magic of Papusza comes from the willingness to retrieve the time which has almost passed into oblivion. At the same time, they establish a separate imagery of that world ${ }^{35}$. All those undertakings are based on the willingness to learn more and spread the knowledge about the Roma culture and Papusza, the poet, and indirectly, also on the need to share the feelings accompanying the artists which have shaped the final film: nostalgia and melancholy, but also memory, hope and freedom.

d) the ideological function of Papusza is not related to "ideology" understood and defined in the outmoded political sense, but rather to the modern tendency to reinterpret various notions and assume certain perspectives, such as the feminist one. According to that statement, the film may be said to refer to a concrete way of thinking of the women question and their role in the society.

e) the economic aspect of the film made by the Krauze duo suggests the need to focus the researcher's attention on three stages: production, distribution and "consumption" of the film. At each stage, directors showed great understanding

35 Papusza's poetry performed similar functions. For her, the creative work was like a magical spell, a secret skill and love. This is visible in her Szarika-marika poem, which reads: “(...) fly, come here!/Oh, my song! Where are you today, my heart?” (Papusza, Lesie, ojcze mój, p. 33). 
of the mechanisms of the art market. They managed an uneasy feat: achieved financial success without resignation from their own recognisable artistic style. Papusza is a fully original and artistic film without the burden of necessity to draw huge audiences to cinemas.

Finally, the most important function of Papusza consists in modelling the social ties. It is difficult to state whether the task has been completed. Definitely, the film revealed positive contexts for thinking about the Romani culture: artistic creation, willingness to learn, war experience close to that of Poles. It allows the recipients to better understand the culture and realise that the contemporary problems stem from certain sources. However, will the connection between "us" and "them" (and thus elimination of the division) be ever fully established? It is difficult to judge that today.

\section{Bibliography}

Ficowski, Jerzy. Cyganie w Polsce. Dzieje i obyczaje [The Romani in Poland]. Warszawa: PIW, 1953.

Golka, Marian. Sztuka w socjologicznych ramach [Art in the sociological framework]. In: Marian Golka, Socjologia sztuki, . Warszawa: Difin, 2008.

Kuźniak, Angelika. Papusza. Wołowiec: Czarne, 2013.

Machowska, Magdalena. Bronisława Wajs - Papusza. Między biografiąa legenda [Bronistawa Wajs - Papusza. Between a Biography and a Legend]. Kraków: Nomos, 2011.

Okely, Judith. The Traveller Gypsies. Cambridge: Cambridge University Press, 1983.

Papusza. Lesie, ojcze mój [Forest, My Father].Warszawa: Nisza, 2013. 


\section{Part 4: Theory and Small Cinemas}





\title{
Krzysztof Loska \\ Instytut Sztuk Audiowizualnych, Uniwersytet Jagielloński, Poland \\ 13. Migrants and exiles in the films by Katarzyna Klimkiewicz
}

\begin{abstract}
A methodological starting point is transnationalism as understood by Will Higbee and Song Hwee Lim who claim that the concept does not only refer to coproduction or global distribution but also includes political, cultural and social factors that help promote understanding contemporary cinema and the world around us. This is the perspective I would like to assume when analyzing the films by Katarzyna Klimkiewicz who mainly focuses on ethnic minorities and their problems. Klimkiewicz presents the lives of political and economic refugees, raising the issues of multicultural society, racism and discrimination. I concentrate on Klimkiewicz's short film entitled Hanoi-Warszawa (2009) and her feature debut Flying Blind (2012), made in Great Britain. On the basis of these two examples, I would like to prove that contemporary cinema tackles "a migrant issue" in different ways: one refers to the poetics of a documentary and allows the "subaltern Others" speak, while the other makes use of the genre conventions.
\end{abstract}

Keywords: Transnational cinema, immigrants, orientalism, Vietnamese diaspora in Poland

It seems that the concept of transnationalism has become ubiquitous in contemporary film studies. The issues of border crossings, flows, and cultural hybridity are frequently raised by scientists; however, it seems that Polish films are rarely analyzed in this context. Polish researchers still seem to find penchant in using the category of national cinema, which was already worked over a long time ago, thanks to the theoretical and empirical findings of Andrew Higson or Matte Hjort. ${ }^{1}$ Nevertheless, a paradigm shift may be noticed with a recently published book Polish Cinema in a Transnational Context, in which the editors - Ewa Mazierska and Michael Goddard - convincingly justify the thesis that in recent years there has

1 See Andrew Higson, “The Limiting Imagination of National Cinema," in: Cinema and Nation, eds. M. Hjort and S. MacKenzie (London: Routledge, 2000), pp. 63-74. Mette Hjort, "On the Plurality of Cinematic Transnationalism," in: World Cinemas, Transnational Perspectives, eds. Nataša Ďurovičová and Kathleen Newman (London: Routledge, 2010), pp. 12-33. 
been a turn consisting in "transition from analyzing textual aspects of a film to considering it as part of the production and reception system.".

I do not intend to refer only to the two aforementioned dimensions of transnationalism. On the contrary, I would like to refer to the proposals made by Will Higbee and Song Hwee Lim, who stated that the concept of transnational does not only concern the issues of co-production and global distribution, but also takes into account political, cultural and social factors enabling a better understanding of today's cinema and the world around us. ${ }^{3}$ This is the perspective one should assume when analyzing diasporic films, whose authors focus on the problems of ethnic minorities and illustrate the consequences of demographic change, talking about the lives of political and economic refugees, or consistently raising the issues such as life in a multicultural society, racism or discrimination.

In anthropological reflection on migratory movements that reveals their impact on the ongoing cultural transformation and the emergence of new transnational ties, one can often notice the references to media images. This is particularly clear in Arjun Appadurai's concept, in which the functioning of culture is explained on the basis of the model that aims at revealing the interrelations of various scapes: ethnic, medial, technological, economic or ideological ones. ${ }^{4}$ The British anthropologist argues that there do not exist any clear barriers separating "us" from "them," and that a national identity has lost its past character based on cohesion and unity of experience. In return, it has gained a new characteristic: a hybrid and cosmopolitan in nature. Contemporary world is viewed by Appadurai in terms of exchange and interpenetration of economic, political and cultural aspects. ${ }^{5}$

All these factors are crucial for understanding the idea of transnational cinema, and I am going to focus on them in my analysis of two films made by Katarzyna Klimkiewicz: a short film Hanoi-Warszawa (2009), which received the Special

2 Ewa Mazierska, Michael Goddard, "Introduction: Polish Cinema beyond Polish Borders," in: Polish Cinema in a Transnational Context, eds. Ewa Mazierska and Michael Goddard (Rochester: University of Rochester Press, 2014), pp. 3-4.

3 See Will Higbee, Song Hwee Lim, "Concepts of Transnational Cinema: Towards a Critical Transnationalism in Film Studies," Transnational Cinemas, Vol. 1, No. 1 (2010), pp. 7-21.

4 See Arjun Appadurai, Modernity at Large: Cultural Dimensions of Globalization (Minneapolis: University of Minnesota Press, 1996), pp. 33-36.

5 One may find a similar approach in Edward W. Said's texts, when he writes that "all cultures are involved in one another, none is single and pure, all are hybrid, heterogeneous, extraordinarily differentiated, and monolithic." See Culture and Imperialism (New York, Vintage Books, 1994), p. XXV. 
Jury Award at the Gdynia Polish Film Festival for "inscribing Polish cinema in the broad emancipation processes," and her feature debut Flying Blind (2012), made in Great Britain. ${ }^{6}$ By choosing these two films, I also wish to emphasize Klimkiewicz's different approaches to the issue of immigration: the first one makes use of the poetics typical of a documentary, thanks to which it creates the impression of authenticity, whereas the second one follows the conventions of a melodrama, in which the themes of intercultural romance and forbidden love play a crucial role. The main difference between these approaches does not only lie in the aesthetic, but also in ideological choices, as it is connected with the construction of otherness and the adoption of a specific cognitive perspective. In Hanoi-Warszawa, the director lets the "subaltern speak" (to use Gayatri Chakravorty Spivak's phrase), ${ }^{7}$ whereas in Flying Blind, she identifies with the point of view of a white Englishwoman. What is more, Klimkiewicz also employs orientalist strategies, whereby the representatives of ethnic minorities are exoticized and, at the same time, presented in a stereotypical way as potential criminals, terrorists or passionate lovers. ${ }^{8}$

The problem of illegal immigration and racial discrimination rarely appears in Polish cinema, while the intercultural exchange generally boils down to the encounters with "the others" that have been dwelling the Polish mind for centuries and has always meant the Jews or the Roma. One exception may be Marcin Wrona's film Moja krew (My Blood, 2009), which tells the story of the Vietnamese diaspora, although it is presented from the point of view of a Polish boxer Igor (Eryk Lubos), who falls in love with an Asian girl. In the same year, Katarzyna Klimkiewicz made a documentary of a totally different character, free of any melodramatic elements. The film told the story of Mai Anh, a young Vietnamese woman, who illegally crossed the eastern border of Poland to reach Warsaw and find her boyfriend. The 30-minute film included a number of key themes typical

6 Having graduated from the Lodz Film School, Katarzyna Klimkiewicz (b. 1977) made a documentary Labirynt Krystiana Lupy (The Labirynth of Krystian Lupa, 2003) presenting the work of the eminent Polish theatre director. Her later projects clearly followed a transnational model of production: she made a short film in Berlin Wasserschlacht: The Great Border Battle (2007) about the residents of two neighboring districts in Berlin: Friedrichshain and Kreuzberg, followed by a feature film made in Israel Nic do stracenia (Nothing to Lose, 2009) - a story of two young Jews who roam the country.

7 See Gayatri Chakravorty Spivak, "Can the Subaltern Speak?," in: The Post-colonial Studies Reader, eds. Bill Ashcroft, Gareth Griffiths and Helen Tiffin (London and New York: Routledge, 1995), pp. 28-37.

8 I am using the term „orientalism“ in Edward W. Said's understanding. 
of European diasporic cinema, such as human trafficking, a sense of alienation, or complexity of relations between an ethnic majority and minority. ${ }^{9}$

From the beginning of the film, the director adopts the main character's perspective (Mai Anh), but at the same time keeps a distance, achieving this effect mainly due to the use of a foreign language throughout the film. The first sequence introduces the main themes: one of them concerns a group of Vietnamese people, working at the 10th Anniversary Stadium in Warsaw and trading things on one of the largest bazaars in our part of Europe. The second theme focuses on a group of illegal immigrants who silently endure humiliation, while crossing the "green border." In this way, Klimkiewicz draws our attention to the dark side of mobility and migration, namely, human trafficking, which since the beginning of the new century has become a symbol of transnational nature of the criminal activity. ${ }^{10}$ Mai Anh (Thu Ha Mai) who gets sexually abused by her traffickers, manages to escape and, with the help of a young Polish couple whom she accidentally meets on her way (Klaudia Barcik and Przemysław Modliszewski), she somehow gets in touch with her fiancé and reaches Warsaw.

In her short film, Klimkiewicz captured one of the most important features defining the perception of minorities by a dominant majority. An illegal immigrant is not treated as a guest or a citizen, but as someone of a lower social status. Alessandro Dal Lago, an outstanding Italian sociologist, uses the term non-person, describing a man deprived of any rights, someone that can be arrested without

9 A notion of the diasporic cinema is an ambiguous category that refers both to the concept of an accented cinema suggested by Hamid Naficy, An Accented Cinema: Exilic and Diasporic Filmmaking (Princeton: Princeton University Press, 2001), and to Will Higbee's theory of transvergence, "Beyond the (Trans)national: Toward a Cinema of Transvergence in Postcolonial and Diasporic Francophone Cinema(s)," Studies in French Cinema, Vol. 7, No. 2 (2007), pp. 79-91.

10 According to the UN definition: "Trafficking in persons shall mean the recruitment, transportation, transfer, harbouring or receipt of persons, by means of the threat or use of force or other forms of coercion, of abduction, of fraud, of deception, of the abuse of power or of a position of vulnerability or of the giving or receiving of payments or benefits to achieve the consent of a person having control over another person, for the purpose of exploitation. Exploitation shall include, at a minimum, the exploitation of the prostitution of others or other forms of sexual exploitation, forced labour or services, slavery or practices similar to slavery, servitude or the removal of organs" (Protocol to Prevent, Suppress and Punish Trafficking in Persons Especially Women and Children, supplementing the United Nations Convention against Transnational Organized Crime, Adopted and opened for signature, ratification and accession by General Assembly resolution 55/25 of 15 November 2000). 
a reason, searched and deported. ${ }^{11}$ Mai Anh is treated like an object, stripped of any dignity, and raped by a Polish driver (Michał Podsiadło) who smuggles people across the border. Her boyfriend, Thran (Le Thanh Hunh), is captured by the police together with a group of foreigners residing in the vicinity of the former 10th Anniversary Stadium. Both Hanoi-Warszawa and Flying Blind prove that an "illegal immigrant" does not only make a legal but also an anthropological category, because it denotes someone perceived as a threat. From such a point of view, it is the victim of persecution that should feel suspect and guilty. ${ }^{12}$

In one of the interviews, the director explained the reasons for her interest in the life of the Vietnamese diaspora in Poland: "I was wondering what it is like when someone becomes a "second-class" person. There was a time when the Poles who lived abroad were regarded as the "second-class" people. It turns out that in Poland, in our homeland, there are still foreigners who - due to our state policy cannot feel free or live the way they want. For me it was a new experience - to be on the other side, because before it was me who was "the other". Because of that I also experienced a bond of solidarity with those who feel this way in Poland."13

Poles are generally portrayed in the media as a nation of immigrants, for decades leaving their homeland, first for political, then for economic reasons. Katarzyna Klimkiewicz and Marcin Wrona have turned their attention to a new phenomenon, associated with the influx of foreigners from different parts of the world, who dream of a better life or flee persecution, and settle down in Poland. Within the past few years, the number of applications for permanent residence card in Poland has increased by half, and the statistics show that the Vietnamese make the second largest national minority that settle in our country (Ukrainians being the most numerous one).$^{14}$ Officially there live thirteen and a half thousand Vietnamese in Poland; however, according to the estimates that take into

11 See Alessandro Dal Lago, Non-Persons. The Exclusion of Migrants in a Global Society (Milano: IPOC Press, 2009), pp. 231-232.

12 When writing about refugees and migrants, Giorgio Agamben claims that "the separation between humanitarianism and politics that we are experiencing today is the extreme phase of the separation of the rights of man from the rights of the citizen." Giorgio Agamben, Homo Sacer. Sovereign Power and Bare Life (Stanford: Stanford University Press, 1998), p. 183.

13 Đàm Vân Anh, Katarzyna Klimkiewicz, "Do tej pory to ja byłam obca," Warszawa wielu kultur (2010), 15 August 2017, http://kontynent-warszawa.pl/content-6-felietony5929-do_tej_pory_to_ja_by\%C5\%82am_obca.htm.

14 According to the data of December 2013, 121,000 non-EU residents were the valid permanent residence cardholders in Poland. In the last five years, this figure has risen by 44,000 . Most migrants come from the countries of the former Soviet Union, but a 
account illegal immigration, there are three times as many altogether. The vast majority of them live in Masovian Voivodeship, mostly in suburban towns (in the municipalities of Raszyn and Lesznowola) and in the capital itself (in Wola and Ochota districts in the city center). Not many of them declare the intention to stay in Poland for good; usually they come only for a few years to earn reasonable money and then return to their families. ${ }^{15}$

In Moja krew and Hanoi-Warszawa, the audience have the rare opportunity to see the image of the Vietnamese diaspora in Poland..$^{16}$ Both films emphasize cultural and traditional differences between the Polish majority and the Vietnamese minority, whose members prefer to live in a close-knit group. In contrast to Katarzyna Klimkiewicz, Marcin Wrona does not avoid the temptation of using a (pseudo-)ethnographic perspective and presents a snapshot of daily life of the Vietnamese, the scenes of their leisure activities, even their prayers in a Buddhist temple. The action of Wrona's film is set at around the same time as Klimkiewicz's documentary, that is, soon after the authorities' decision to close down one of the biggest open-air markets at the 10th Anniversary Stadium, which resulted in the majority of the Vietnamese moving to the shopping market in Wólka Kosowska. However, the bazaar remained the most characteristic feature of their world, consisting of a myriad of tin stalls, on which they sell clothes, a number of small bars serving Asian cuisine, and narrow alleys intersecting the area. ${ }^{17}$

Moja krew presents the image of an integrated community living its own life, while Hanoi-Warszawa focuses on a phenomenon, which is rarely discussed in the media, namely, human trafficking in which organized criminal groups are involved, and migrants' slave labor. Due to the difficulties in obtaining visas and a high cost of travel, illegal immigrants are often forced to work off the debt they earlier incurred. The newcomers of Mai Anh's kind have limited knowledge of

significant number (11\%) includes the Vietnamese. See Konrad Pędziwiatr, "Imigranci w Polsce i wyzwania integracyjne," Studia BAS, No. 4 (40) (2014), pp. 137-138.

15 A history of the Vietnamese diaspora in Poland dates back to the late 1960s when a lot of young Vietnamese, who had fled from their war-stricken homeland, studied at Polish universities. The second wave of immigration came with political changes in Vietnam in the late 1980s.

16 In 2006, Anna Gajewska made a short documentary Warszawiacy (Varsovians), in which the Vietnamese tell about the reasons for which they had come to Poland and describe their life in exile.

17 A medium-length film Making of 'Hanoi-Warszawa' made by Marta Ambrosiewicz and Paweł Gliński for the Kino Polska TV channel brings a lot of interesting details on the work by Katarzyna Klimkiewicz. 
Poland, they do not speak the language, and therefore, they are totally dependent on their employers who ruthlessly exploit them. ${ }^{18}$ Some immigrants are hiding from the police and use false names, as does the Mai's fiancé, hoping that in this way they will avoid deportation. In 2012, the Polish government announced the abolition program for foreigners residing in the country without a valid residence card, and nearly fifteen hundred Vietnamese profited from it. ${ }^{19}$

One of the sources of inspiration for Hanoi-Warszawa was Klimkiewicz's meeting with Ton Van Anh, a Vietnamese political activist, who has been living in Poland for twenty years and who organizes assistance for refugees. It was she who introduced Katarzyna Klimkiewicz into the Vietnamese diaspora, helping as a translator and intermediary in their contacts. She also told her stories of numerous Vietnamese people trying to get into our country. "Many of these stories were shocking, in the beginning I could not believe her, and I thought she was exaggerating. I had not realized before how difficult the experiences of the Vietnamese were. It was hard for me to believe that nobody speaks loudly about these things. I began to double-check the stories Ton Van Anh had told me, for example, I spoke with people working for the La Strada Foundation and the border guards in Przemyśl. It turned out that the dramatic experiences of Vietnamese trying to cross the border illegally were true. The story we tell in Hanoi-Warszawa could happen in reality. I tried to make it as credible and realistic as possible. All the situations depicted in the film could occur in reality." ${ }^{20}$

The documentary has won many awards and honors, but it was the screening at the Short Film Festival in Bristol that made a turning point in Klimkiewicz's artistic career. Alison Sterling, an independent producer, working for Ignition Films company, was at the time preparing the production of a film Flying Blind based on the script written by Caroline Harrington and Naomi Wallace. A story of a romance between a middle-aged woman and a much younger Algerian immigrant seemed the good material for a feature debut for a Polish film director who had already shown interest in intercultural relations, although the poetics of

18 For human trafficking in contemporary cinema, see Krzysztof Loska, "Ciała na sprzedażmroczna strona globalizacji," Kwartalnik Filmowy, No. 83-84 (2013), pp. 306-316.

19 See Ignacy Jóźwiak, Anna Piłat, Justyna Segeš Frelak, Kinga Wysieńska and Mirosław Bieniecki, "Migracje społeczności z Azji i Bliskiego Wschodu na świecie i do Polski stan badań i opracowanie na temat wybranych krajów," in: Mała Azja w Polsce. Plany i strategie imigrantów $z$ Azji i Bliskiego Wschodu (Warsaw: Instytut Spraw Publicznych, 2013), p. 79.

20 Anh, Klimkiewicz, Do tej pory to ja bytam obca. 
melodrama and thriller somehow limited the author's ability to voice her artistically original creativity.

I am not going to write about the way the genre conventions are employed in the film - it is not particularly original in this regard - but I would like to place Flying Blind in a broader political and cultural context. First, one should take into account the burden of orientalist thinking, which is responsible for creating a set of collective ideas about other cultures and people; second, one should bear in mind a certain "Islamophobia" of British society, which resulted from a fear of religious fundamentalism; third, one should not forget the political context of the "war on terror" led by Western countries after the attacks on the World Trade Center on 11 September 2001.

The main character of the film is Frankie (Helen McCrory) who works in Bristol's aerospace industry and specializes in the construction of drones for the military. She also has a series of guest lectures for students of a technical university. Frankie is a strong and independent woman who efficiently supervises a team of other male professionals. She lives alone in a big house and devotes all the time to her career. From the beginning of the film, we can see that a matter of national security plays an important role both in her professional and personal life. To enter the guarded premises, she must use a special code, the tests she carries out on military devices are strictly confidential, and her projects are supervised by the intelligence services. Even her apartment resembles a fortress, the access to which is controlled by security cameras. The ethical issues relating to the nature of her research seem to be of lesser importance to her. When one of the students asks about her cooperation with the arms industry and scientists' indirect responsibility for the deaths of civilian victims of the bombings, Frankie replies that philosophical issues are not her concern: "Each plane can be used for military purposes. I am more interested in the beauty of a flight than in a plane's fighting ability."

Her whole life changes when she meets a 24-year-old Algerian, Kahil (Najib Oudghiri), who claims to be an engineering student, but in fact is an illegal immigrant in the United Kingdom. He has fled his homeland because of political persecution (the police records show that he spent several months in prison, where he was tortured). Klimkiewicz does not develop the Algerian subplot, the viewers can only guess that Kahil may have participated in anti-government protests organized at the turn of 2010 and 2011 by the opposition parties, which resulted in three demonstrators getting killed, many others injured and arrested. After a few months of the protests, the authorities agreed to introduce the changes in the Constitution, announced the lifting of the martial law and accepted the demands for democratic elections. 
The theme of an intercultural romance - typical of the diasporic cinema - is a ploy aimed to attract the cinema audiences who are usually uninterested in the problems of immigration or politics. This also explains why Klimkiewicz makes use of stereotypes concerning foreigners. ${ }^{21}$ Despite her critical ambitions, the plot seems to be heavy with stereotypical structures, especially in the first half of the film, when she introduces the theme of sexual infatuation and refers to the Orientalist fantasies about Arabs as potential lovers or criminals. Orientalism is not only a political tool, but also a system of knowledge, which serves to justify an imperialist vision of the world and to guarantee its control over the subjugated ones. On the one hand, Klimkiewicz confirms stereotypical opinions about the Orient as being full of contradictions - fascinating but torn with internal conflicts on the other hand, however, she is trying to bring closer the two worlds through the characters' romance.

Nevertheless, the romantic love affair turns out to be less significant than the political background of the story, as the action of the film is set at the time of military conflicts in the Middle East, after the outbreak of Islamophobia accompanied by the process of radicalization among the Muslim community. These issues also appeared in other British films, such as Yasmin (2004) by Kenneth Glenaan or The Road to Guantanamo (2006) by Michael Winterbottom. It was the time when the Muslims were predominantly presented in the media as jihadists, members of the "fifth column," and the opponents of democracy or civil rights. Jonathan Birth, who analyzed the phenomenon of Islamophobia, defines it as "a kind of cultural racism (...) producing community of the suffering ones, the aim of which is to unify various ethnic communities by giving them Muslim identity."22

For centuries, the Orient was presented as a potential threat to European governance; it was something foreign and unknown, which required taming and ordering. At the same time, the Orient was perceived as the source of fascinating ideas, exotic scenery for the romantic visions of poets and writers, and the symbol of carnal temptations and unrestricted manifestations of sexuality. ${ }^{23}$ Katarzyna

21 A romance between the representatives of different ethnic groups is a popular theme in British cinema set in South-Asian diasporic communities: Sammy and Rosie Get Laid (1987, Stephen Frears), My Son the Fanatic (1997, Udayan Prasad), East is East (1999, Damien O'Donnell), Ae Fond Kiss... (2004, Ken Loach) and Nina's Heavenly Delights (2006, Pratibha Parmar).

22 Jonathan Birt, "Islamophobia in the Construction of British Muslim Identity Politics," in: Muslims in Britain. Race, Place and Identities, eds. Peter Hopkins and Richard Gale (Edinburg: Edinburgh University Press, 2009), p. 217.

23 See Edward W. Said, Orientalism (New York: Pantheon Books, 1978). 
Klimkiewicz elaborates on these seemingly contradictory dimensions when focusing on the emotional relationship of the protagonists. Their uncertainty and fear of betrayal are accompanied by strong sensual infatuation. It should be noted that the Orientalist fantasies always contain an element of value judgment, emphasizing the traits undesirable in Western societies, such as irritability, succumbing to passions, violent behavior and betrayal.

As if following these assumptions, Klimkiewicz presents a deliberately ambiguous image of Kahil. The viewer will never discover the real motives of his actions, because everything we know about him is filtered through Frankie's eyes. In the beginning, she succumbs to the temptation of an exotic romance; after some time, however, she starts to take on some suspicion. She feels a strong urge to discover the truth about the young man: is he simply her lover, a political refugee or a terrorist? Several clues seem to confirm her concerns - her first meeting with Kahil may not have been accidental, she could have been chosen as a target because of her line of work. One day she bumps into Kahil's ex-girlfriend in the street and takes this opportunity to learn some disturbing facts about his past. Moreover, she finds the photos and articles on radical Muslim groups in his computer and discovers hidden guns in his apartment. Kahil does not deny having radical views, and blames her for the consequences of the barbaric bombings in which many civilians were killed: "Do you know what they are doing and who your drones kill?" Yet, at the same time, he claims to reject all military actions. "People like you think they know everything but in fact you know nothing", he tells Frankie in one of the last scenes, just before the deportation, when he finds out that the police and secret services have been tracking him down from the very beginning.

Like the previously mentioned films by Kenneth Glenaan or Michael Winterbottom, Flying Blind shows the change that occurred in the cinema in the last twenty-five years, with the narrative of the Cold War being replaced with the fight against terrorism and the "clash of civilizations" as the main themes in new films. The term "war on terror," introduced by President George Bush in his speech after the attacks on the World Trade Center, "is often used to describe a special, historically conditioned form of political violence." ${ }^{24}$ It should be noted that this term implies actions, both conventional and unconventional, that strengthen stereotypical ideas about Islamic fundamentalism, in spreading of which the mass media and the cinema play a prominent role. ${ }^{25}$

24 Bruce Bennett, "Framing Terror: Cinema, Docudrama and the 'War on Terror," Studies in Documentary Film, Vol. 4, No. 3 (2010), p. 210.

25 See Bennett, "Framing Terror," p. 222. On complex relations between the cinema and military technologies, see Paul Virilio, War and Cinema: The Logistics of Perception 
On the other hand, Samuel Huntington's vision of the world, based on the concept of a radical disparity of civilizations (rather than cultures), whose members profess different values and, therefore, remain in dispute, has found strong support among conservatives seeking a scientific justification for a unifying perception of reality. ${ }^{26}$ In this way, the otherness is constructed by a chain of stereotypes, through which minority is seen as a potential threat and the source of all evil. According to Edward W. Said, this strategy of thinking is based on a "presumption of guilt on the part of a man of the Orient; what is more, his crime consists precisely in being the one." ${ }^{37}$

The construction of a collective identity requires emotional involvement, not reasoning or clear thinking, and this is exactly what happens to Frankie: as if against her will, she lets herself be guided by her feelings, misinterpretations and prejudices. Behind a romantic story mixed with a thriller, one can notice a political drama that concerns the influx of contemporary immigrants in Western European countries and growing hostility against Muslims. When considering the modern Islamophobia, one should start by asking "to what extent the discrimination and exclusion experienced by Muslims in Europe is driven by religious or cultural, ethnic, racial and class-related factors." 28

When explaining the nature of modern aversion to Muslims, Monika Babako shows some similarities to anti-Semitism. "The target of the attacks are those considered to be irreducibly 'foreign' or those who threaten the purity of European/ national identity, European/national social order, economic interests, political values and ways of life." ${ }^{29}$ In any case, the enemy is defined by a series of mutually exclusive features: as someone weak and at the same time dangerous, someone poor and boasting unlimited financial resources, or someone both barbarous and refined. The conclusion derives from a specific intellectual strategy, which aims to demonstrate the epistemological and ontological differences between East and West.

Katarzyna Klimkiewicz reveals how Islamic terrorists become "orientalized," when they are associated with stereotypical notions of ruthless, irrational and cruel people of the East, contrasted with rational and democracy-loving citizens

(New York: Verso, 1989). In the establishing sequence of his Four Lions (2010), Chris Morris mocks the way terrorists use the media.

26 See Samuel Huntington, The Clash of Civilizations and the Remaking of World Order (New York and London: Simon and Schuster, 1996).

27 Said, Orientalism, p. 77.

28 Monika Babako, "Islamofobia - między „krytyką religii“ a rasizmem kulturowym," Recykling Idei, No. 14 (2012/2013), p. 15.

29 Babako, "Islamofobia," pp. 21-22. 
of the West. To some extent, Klimkiewicz's film follows a scheme once described by Elizabeth Ezra and Terry Rowden, according to which the phenomenon of terrorism in the modern cinema boils down to constructing a negative image of an immigrant as a potential threat, at the same time, presenting foreign cultures as "exotic" (this may be more clearly seen in the Hollywood productions where white Americans save the world from the evil "colored" ones who want to destroy it). ${ }^{30}$

Homi K. Bhabha was one of the first researchers who drew attention to the fact that after the attacks on the World Trade Center, the modern forms of terrorism began to be viewed as a part of a broader phenomenon, namely, the aforementioned "clash of civilizations." The British anthropologist added, however, that such a reasoning contributes to the growth of aggression in political discourse, resulting in the birth of "psychosis leading to the persecution of the weak and the oppressed." ${ }^{31}$ The Clash of Civilizations implicitly justifies all sorts of actions taken by Western governments in order to eliminate the potential danger. But the opportunity to oppose the terrorist attacks may become possible only when "terrorism begins to be seen as an organized political action and not the result of cultural or civilizational difference." 32

In Flying Blind, Katarzyna Klimkiewicz managed to capture the impact of politics on the lives of ordinary people, and to draw attention to the consequences of unconscious assumptions being made about other cultures. The Polish director does not show any actual terrorist activities and evades clear explanations as to the nature of Kahil's motivations, leaving them for the viewers to guess. Instead of passing moral judgments or condemning anybody, she remains outside simply looking inside her characters' world. Her ability to inscribe the important political and social issues in the genre conventions prove to be one of the greatest values of both of her films, which touch the issues of illegal immigration, ethnic identity, intercultural conflict and the dangers brought on by the war on terror. Today these problems are considered both in local and global contexts, and therefore require taking a transnational perspective, which allows us to see the connections between seemingly distant areas.

30 Elizabeth Ezra and Terry Rowden, "General Introduction: What is Transnational Cinema?," in: Transnational Cinema: The Film Reader, eds. Elizabeth Ezra and Terry Rowden (London: Routledge, 2006), p. 12. The final part of the book is titled Tourists and Terrorists.

31 Homi K. Bhabha, “Terror and After...," in: Transnational Cinema: The Film Reader, eds. Elizabeth Ezra and Terry Rowden (London: Routledge, 2006), p. 197.

32 Bhabha, "Terror and After," p. 198. 


\section{Bibliography}

Agamben, Giorgio. Homo Sacer. Sovereign Power and Bare Life. Stanford: Stanford University Press, 1998.

Anh, Đàm Vân and Katarzyna Klimkiewicz. "Do tej pory to ja byłam obca." Warszawa wielu kultur. 2010. http://kontynent-warszawa.pl/content-6felietony-5929-do_tej_pory_to_ja_by\%C5\%82am_obca.htm (10 Sept. 2016).

Appadurai, Arjun. Modernity at Large: Cultural Dimensions of Globalization. Minneapolis: University of Minnesota Press, 1996.

Babako, Monika. "Islamofobia - między "krytyką religii" a rasizmem kulturowym." Recykling Idei, Vol. 14, 2012/2013. http://recyklingidei.pl/print/bobako-islam ofobia-miedzy-krytyka-religii-a-rasizmem-kulturowym (10 Sept. 2016).

Bennett, Bruce. "Framing Terror: Cinema, Docudrama and the 'War on Terror." Studies in Documentary Film, Vol. 4, No. 3, 2010, 209-225.

Bhabha, Homi K. “Terror and After...." In: Transnational Cinema: The Film Reader, eds. Elizabeth Ezra and Terry Rowden. London: Routledge, 2006, pp. 197-198.

Birt, Jonathan. "Islamophobia in the Construction of British Muslim Identity Politics." In: Muslims in Britain: Race, Place and Identities, eds. Peter Hopkins and Richard Gale. Edinburgh: Edinburgh University Press, 2009, pp. 210-227.

Dal Lago, Alessandro. Non-Persons. The Exclusion of Migrants in a Global Society. Milano: IPOC Press, 2009.

Ezra, Elizabeth and Terry Rowden. "General Introduction: What is Transnational Cinema?” In: Transnational Cinema: The Film Reader, eds. Elizabeth Ezra and Terry Rowden. London: Routledge, 2006, pp. 1-12.

Higbee, Will. "Beyond the (Trans)national: Toward a Cinema of Transvergence in Postcolonial and Diasporic Francophone Cinema(s)." Studies in French Cinema, Vol. 7, No. 2, 2007, pp. 79-91.

Higbee, Will and Song Hwee Lim. "Concepts of Transnational Cinema: Towards a Critical Transnationalism in Film Studies." Transnational Cinemas, Vol. 1, No. 1, 2010, pp. 7-21.

Higson, Andrew. "The Limiting Imagination of National Cinema." In: Cinema and Nation, eds. Mette Hjort and Scott MacKenzie. London: Routledge, 2000, pp. 63-74.

Hjort, Mette. "On the Plurality of Cinematic Transnationalism." In: World Cinemas, Transnational Perspectives, eds. Natasa Durovičová and Kathleen Newman. London: Routledge, 2010, pp. 12-33.

Huntington, Samuel. The Clash of Civilizations and the Remaking of World Order. New York and London: Simon and Schuster, 1996. 
Jóźwiak, Ignacy, Anna Piłat, Justyna Segeš Frelak, Kinga Wysieńska and Mirosław Bieniecki. "Migracje społeczności z Azji i Bliskiego Wschodu na świecie i do Polski - stan badań i opracowanie na temat wybranych krajów." In: Mała Azja $w$ Polsce. Plany i strategie imigrantów z Azji i Bliskiego Wschodu, eds. Anna Piłat, Justyna Segeš Frelak and Kinga Wysieńska. Warsaw: Instytut Spraw Publicznych, 2013.

Loska, Krzysztof. “Ciała na sprzedaż - mroczna strona globalizacji.” Kwartalnik Filmowy, No. 83-84, 2013, pp. 306-316.

Mazierska, Ewa and Michael Goddard. "Introduction: Polish Cinema beyond Polish Borders." In: Polish Cinema in a Transnational Context, eds. Ewa Mazierska and Michael Goddard. Rochester: University of Rochester Press, 2014, pp. 1-20.

Naficy, Hamid. An Accented Cinema: Exilic and Diasporic Filmmaking. Princeton: Princeton University Press, 2001.

Pędziwiatr, Konrad. "Imigranci w Polsce i wyzwania integracyjne." Studia BAS, Vol. 4, No. 40, 2014, 137-138.

Protocol to Prevent, Suppress and Punish Trafficking in Persons Especially Women and Children, supplementing the United Nations Convention against Transnational Organized Crime. Adopted and opened for signature, ratification and accession by General Assembly resolution 55/25 of 15 November 2000.

Said, Edward W. Orientalism. New York: Pantheon Books, 1978.

Said, Edward W. Culture and Imperialism. New York: Vintage Books, 1994.

Spivak, Gayatri Chakravorty. “Can Subaltern Speak?” In: The Post-colonial Studies Reader, eds. Bill Ashcroft, Gareth Griffiths and Helen Tiffin. London and New York: Routledge, 1995, pp. 28-37.

Virilio, Paul. War and Cinema: The Logistics of Perception. New York: Verso, 1989. 
Agnieszka Kiejziewicz

Instytut Sztuk Audiowizualnych, Uniwersytet Jagiellon'ski, Poland

\title{
14. From controversy to contemplation: The thematic areas of the new Japanese avant- garde and experimental film in comparison to the "old masters" of Japanese avant-garde
}

\begin{abstract}
After the year 2000, the rapid development of the visual experimental and avantgarde art in Japan can be noticed. The new generation of the creators, who considers themselves as the founders of "the new avant-garde movement," focuses on expanding the technological and thematic areas set by the independent artists from the 1970s and 1980s. Observing the unique works of the famous Collective Plus [+] and other recognizable filmmakers, the viewer can experience a wide range of themes, including the spiritual contemplation, ecological issues and problems with rapid urban development. However, among the works of the new generation of the avant-garde and experimental filmmakers, it is almost impossible to find the controversial subjects and controversies on the screen. Comparing the new experimental visual art to the topics and the ways of presentation used by the "old masters" of the Japanese avant-garde (such as Shuji Terayama, Takahiko Iimura or later Shinya Tsukamoto) it can be easily observed that the new generation avoids the subjects that might be considered to be controversial. Instead, they encourage the viewer to contemplate the beauty of the abstract, technologically advanced visions.

In this chapter, the author focuses on the comparison of the thematic areas of two generations of the Japanese independent artists, wondering why the new generation of the Japanese filmmakers avoids the controversial themes while stating that they follow the postulates of the old masters.
\end{abstract}

Keywords: Avant-garde, Japanese film, controversy, thematic areas, Takashi Makino, Kazuhiro Goshima, Shūji Terayama, experimental film, audiovisual experiment, Japan

\section{Introduction}

The avant-garde film on Japanese ground emerged from the successful combination of the aesthetics of the New Wave cinema (jap. nüberu bāgu), the body transgressions of the "pink films" (jap. pinku eiga) ${ }^{1}$ and the eventful atmosphere of the 1960s. It was the time, when the Treaty of Mutual Cooperation and Security

1 See: Jasper Sharp, Behind the Pink Curtain. The Complete History of Japanese Sex Cinema (Godalming: FAB Press, 2008). 
between the United States and Japan, known as ANPO, was signed by Japanese government on May 20, 1960. The ratification of the treaty led to the protests, uniting students, artists, workers and other groups within Japanese society ${ }^{2}$.

Writing about the first generation of the Japanese avant-garde artists, Isolde Standish mentions that: "A generational consciousness based on political opposition was intimately linked to the student movements of the 1950s and 1960s. Also, they shared experiences as Japan's first generation of post-war filmmakers who were artistically stifled by a monopolistic and hierarchal commercial studio system $[\ldots]^{\prime \prime}$. According to this observation, the artistic pursuits of the first avant-garde directors can be perceived as opposed to commercialism and classical Japanese cinema. The new counter-cinema also addressed a different audience: politically conscious and interested in novelty offered by perception-challenging visual forms ${ }^{4}$. Also, the visual aesthetics of surrealism, mostly known from the Western pictures of Buñuel and Cocteau ${ }^{5}$, inspired the Japanese avant-garde movement. Among the Japanese authors, working in the 1960s and 1970s, who had a significant influence on the shape of the further audiovisual experiments, there should be mentioned Shūji Terayama and Jūrō Kara ${ }^{6}$. They mainly focused on the theme of body transgressions, searching for new ways of establishing contact with the viewers and encouraging them to reconsider the social and political reality.

Between the 1970s and 1980s, besides the continuous development of the avant-garde forms, the experimental branch of audiovisual forms appeared on the Japanese ground. The most prominent artists of that time, Toshio Matsumoto and Takahiko Iimura, brought fresh insight into the world of a creative usage of the film techniques. At the other end of the scale should also be mentioned Ichiro Sueoka and Mako Idemitsu, female artists, who underlined the problems of the "second gender" in the Japanese society and undertook the polemics with the "male culture." The middle and late 1980s brought to life an innovative hybrid of the newest technologies and avant-garde aesthetics - "technological avant-garde."

2 Wesley M. Sasaki-Uemura, Organizing the Spontaneous: Citizens Protest in Postwar Japan (Honolulu: University of Hawaii Press, 2001), pp. 24-49.

3 Isolde Standish, Politics, Porn and Protest. Japanese Avant-Garde Cinema in the 1960s and 1970s (New York and London: Continuum, 2001), p. 1.

4 See: Standish, Politics, p. 1-10.

5 See: Mark Schilling, "Japanising the Dark Side: Surrealism in Japanese Film," in: The Unsilvered Screen: Surrealism on Film, eds. Graeme Harper and Rob Stone (London, New York: Wallflower Press, 2007), pp. 134-142.

6 Several studies and publications describe the films, performances and life of Shūji Terayama. See: Standish, Sorgenfrei. 
The representatives of that current revolved around technophobia and through the futuristic visions of the cyber, metal bodies, strived to depict threats and hopes of the computer era.

Japanese avant-garde cyberpunk as a film genre emerged from the aesthetics of the New Wave transgressions, Japanese and Western Science Fiction and the experiments of the previous independent authors. Filmmakers such as Tsukamoto or Izumiya tried to show on the screen the alternative visions of the future, in which the fusion of technology and humans' curiosity will bring to life a new kind of monster - superhuman. Among the best known independent "cyberpunks," Shinya Tsukamoto ${ }^{7}$, Sōgo Ishii ${ }^{8}$, Shōjin Fukui ${ }^{9}$ and Shigeru Izumiya ${ }^{10}$ should be mentioned. While the first one is widely known as the "father of the Japanese cyberpunk," Sōgo Ishii is recognized as the author of films such as Burst City (Bakuretsu toshi, 1982) and Crazy Thunder Road (Kuruizaki sandā rōdo, 1980). $\mathrm{He}$ is also considered to be the precursor of the avant-garde cyberpunk genre on Japanese ground. What is more, mentioned above Shozin Fukui directed cyberpunk films such as 964 Pinocchio (1991) and Rubber's Lover (1996). Another pre-cyberpunk director, Shigeru Izumiya, was the author of Death Powder (Desu pawuda, 1986), in which he presented the first android in Japanese cyberpunkindependent cinema. However, after the popularity boom of the multiplex cinemas in Japan in the $1990 \mathrm{~s}^{11}$, the interest in avant-garde and experimental forms of expression faded away, both among the artists and the publicists. Even though during that period Mako Idemitsu and Takahiko Iimura released some of their less-known works, the overall shape of the Japanese cinema was far from the experimental techniques and topics related to the interests of the avant-garde artists. In that case, the period between 1990 and 2000 can be perceived as a gap between old avant-garde forms and a new dynamic movement.

7 See: Tom Mes, Iron Man. The Cinema of Shinya Tsukamoto (Godalming: FAB Press, 2005). The author provides the complete analysis of Tsukamoto's early films and biographical facts that influenced his art.

8 See: Tom Mes and Jasper Sharp, The Midnight Eye Guide to New Japanese Film (Berkeley: Stone Bridge Press, 2005), pp. 67-69.

9 See: Mes, Sharp, The Midnight Eye, p. 226.

10 See: Graham Lewis, "Pinnochio 964, Death Powder and The Post - Human Condition," in: Japanese Horror Cinema, ed. Jay McRoy, (Edinburg: Edinburg University Press, 2005).

11 To observe the influence of the increasing number of multiplex cinemas on the number and popularity of imported, popular films, see: "Statistics of Film Industry in Japan," Motion Pictures Producers Association of Japan, Inc., 1 Jan. 2017, http://www.eiren.org/ statistics_e/. 
The rapid development of the visual experiment and avant-garde art in Japan after the year 2000 brings many questions on how are the objectives of the new movement, as well as how the young artists, relate their achievements to those presented by the previous generations. It should be underlined that the founders of "the new avant-garde movement" admit to being inspired by the works of other independent artists, but, at the same time, they try to expand the technological and thematic areas set by the golden age of Japanese avant-garde. In this chapter, I will focus on the thematic areas of the new movement to show the variety of themes they cover. Analyzing the works of a highly active group Collective Plus $[+]^{12}$, an independent group of young filmmakers set up by Takashi Makino, Rei Hayama and Shinkan Tamaki and other recognizable filmmakers, such as Kazuhiro Goshima ${ }^{13}$ and Tomonari Nishikawa ${ }^{14}$, I would like to consider the problem of discarding the controversial themes for the spiritual explorations.

It can be observed that the new generation of avant-garde and experimental filmmakers avoids the controversial subjects and even the metaphorical representations of the controversies on the screen. Comparing their visual art to the themes and the ways of presentation used by the "masters" of the Japanese avant-garde, it can be pointed out that the new generation avoids the body transgressions and the subjects that might be classified as controversial, improper or politically incorrect. Instead of trying to shock the viewer, young artists focus on the problems of urbanization, pay considerable attention to coexistence with nature, as well as to the threats and drawbacks of implementing new technologies into the everyday life. The new avant-garde filmmakers also strive to develop their understanding of the newest technological tools that allows them to express the figments of their imaginations adequately on the screen ${ }^{15}$. Here, the problem of the medium and artistic pursuits also becomes the issue presented in the films.

12 More about the group can be found in their publication: Plus Documents 2009-2013, ed. Takashi Makino (Indianapolis: Engine Books, 2014).

13 More about Kazuhiro Goshima (including the list of his films) can be found on his website: Kazuhiro Goshima, Kazuhiro Goshima, (2013): 17 Jan. 2017, http://www. goshiman.com/.

14 The examples of Tomonari Nishikawa's works can be found on his website: Tomonari Nishikawa, Tomonari Nishikawa, (2017): 10 Jan. 2017, http://www.tomonarinishikawa. $\mathrm{com} /$.

15 Agnieszka Kiejziewicz, “The technologies of experimental Japanese filmmakers in the digital era," Transmissions: The Journal of Film and Media Studies, Vol.1, No. 1 (2016), pp. 99-114. 
Considering the fact that the young artists at the same time focus on being politically correct and state that they follow (and even improve) the postulates of the "old masters" 16 , intangibly related to the controversial topics, I will compare the chosen thematic areas with the reasons for the paradigm shift among the young artists. Providing the examples of the films from different cinematic epochs, I will show that the new Japanese avant-garde follows only the visual aesthetics and techniques introduced by the "old masters," leaving behind their postulates.

\section{New generation, new objectives}

The artists working under the label of the new Japanese avant-garde are mostly the graduates of audiovisual studies, who not only pursue their dreams of the new audiovisual experience but also hold a formal education in their fields ${ }^{17}$. They continuously extend their knowledge of the available technologies, what became the identification point of the new generation of the filmmakers. In their postulates, the young filmmakers state that it is important to offer the viewer the best possible quality of the experience. The significant feature of the mentioned Japanese artists is their presence on the Internet and the attention they pay to maintain the close contact with fans. The filmmakers not only post about their newest achievements on their websites and social media profiles, allowing the viewers to comment on their art, but also care to be present at screenings and visit festivals. Thanks to the contact with fans they can respond quickly to the feedback and expectations, which means that their art is constantly a matter of alterations and changes. The young experimenters postulate that improving the form and searching for the perfect image of their projects is one of the most important goals of their generation. What is more, the Internet is eagerly being used by the artists to successfully promote their works to reach the potential donors. It is worth mentioning that the new generation of artists communicates with their fans through the Internet; for example, Takashi Makino and Shinkan Tamaki have their Facebook profiles open for commentaries.

It is not easy to bring together all the postulates of the new generation of avantgarde Japanese artists, as they did not openly publish their manifestos. Unlike

16 See: Takashi Makino, Rei Hayama, Shinkan Tamaki, "Mostra de Cinema Periferico," Youtube, (6 Jun. 2014): 17 Dec. 2016, https://www.youtube.com/watch?v=SUWJRVu77c.

17 For example, Kazuhiro Goshima graduated from Kyoto Institute of Technology. 
Shūji Terayama ${ }^{18}$, who in 1975 published his collected objectives or Iimura ${ }^{19}$, the young artists prefer to reveal their point of view little by little, publishing important thoughts on the websites or mentioning them during the interviews. However, one exception can be a booklet released by Collective Plus [ +$]$, in which the artists featured brief descriptions of their recent works, the interviews, impressions and commentaries ${ }^{20}$. Nevertheless, the representatives of the Collective Plus $[+]$ stated their aims during the 5th edition of the festival Mostra de Cinema Periférico in Spain ${ }^{21}$. They called themselves a "new avant-garde," considering their pictures as a continuation of the achievements of previous generations of Japanese experimental artists. They also mentioned that besides offering new experiences to the viewers, they want to show how the new technologies can be incorporated into the world of art. According to this, the artists hope for extending the widespread knowledge of the cinema-related technologies, which can be beneficial to the viewers in terms of film education. They declare that the main point of their activity is to rescue the Japanese cinema from "the mediocre plots of the popular movies." On the Collective's blog (part of Makino's website), the artists state that: "The main aim of + is to vitalize the art of the essential cinema, made regardless of any existing boundaries, in contrast to blockbusters. [...] + is no longer just a screening project. This is a movement by several different individuals such as filmmakers, musicians, artists and critics. This is a flexible community of those who resonant each other in the moment" ${ }^{\prime 22}$.

Analyzing the presented statements, it can be observed that the young generation perceives the role of the avant-garde movement through its educative purposes. The quality of the screening they want to offer should, according to them, fill out the gap between popular cinema and the need for a meaningful audiovisual experience. Following the working style of famous avant-garde directors, such as Terayama $^{23}$, some representatives of the new generation postulate that forming the groups and collectives is inevitable to obtain a free flow of ideas. Among the postulates and goals the young artists wish to carry out, there should be mentioned the idea of presenting an entirely different face of Japanese cinema abroad.

18 Terayama presented his postulates in the manifesto, see: Shuji Terayama, "Manifesto," The Drama Review, Vol.19, No. 4 (1975), pp. 84-85.

19 Iimura described his main objectives in his publication, see: Takahiko Iimura, The Collected Writings of Takahiko Iimura (Maryland: Wildside Press LLC, 2007).

20 See: Plus Documents, 2014.

21 Takashi Makino, Rei Hayama, Shinkan Tamaki, "Mostra de Cinema Periferico."

22 Takashi Makino, Makino Takashi, (2015): 15 Dec. 2016, http://makinotakashi.net/.

23 To read more about Terayama's working style, see: Standish or Sorgenfrei. 
The artists want to break the stereotypical view of Japanese cinema through the prism of jidai geki $i^{24}$ and $k a i j{ }^{25}$ films and bring attention to the unknown aesthetic currents. It should be underlined that every experimental artist also has his own postulates, mainly connected to the leading theme of his or her works. However, the mentioned goals, such as the promotion of art, creating the new quality of cinema and personal development, also reappear in the statements of the young artists.

Comparing the aims of the new experimental artists to the activities performed by the "old masters," it can be perceived that the actions designed to shock the society and create controversy during the 1960 s and later evolved into promotional mechanisms and strategies. For example, the meaning of the artistic collective has changed. The groups of the first Japanese avant-garde artists occupied the city space camping in huge, colorful tents in parks and invaded the streets in noisy processions ${ }^{26}$, trying to manifest their independence, distinctiveness and unity inside the collective. Nowadays, the young artists do not undertake such visible actions, limiting their appearance to screenings held by galleries, local cinemas and universities, therefore being invisible for the wider audience. Also, the contact with fans, obtained through the Internet and personal meetings, lacks the wild mood introduced by Terayama, who could even harass the viewer during the performance to make him "feel" the $\operatorname{art}^{27}$.

\section{Controversial themes of the "old masters"}

The Japanese avant-garde movement, concentrated on the antiestablishment manifestations, did not avoid highly controversial issues. The primary purpose of the artists working then was to shock the viewers, to make them reconsider the reality, cultural norms, the history and the political issues of that time.

Often the avant-garde artists created a caricature, grotesque and unreal picture of the Japanese society to underline the current problems that needed reconsideration. For example, the anti-utopian, terrifying and cruel world was presented

24 Jidai geki is a Japanese film and TV series genre of historical dramas, mostly set in Edo period (1603-1868) of Japanese history.

25 Kaiju eiga is a film (TV, books, manga and games) genre characterized by the appearance of the variety of monsters (for example Godzilla by Ishiro Honda).

26 To read more about Terayama's performance, see Stanca Scholz-Cionca, Japanese Theatre and the International Stage (Leiden and Boston: Brill, 2001), pp. 255-258.

27 Stanca Scholz-Cionca, Japanese Theatre. 
in Terayama's film Emperor Tomato Ketchup (Tomato Kecchappu Kōtei, 1971) ${ }^{28}$. Here, the director depicts the state ruled by the rebellious children, who hunt for the adults to imprison or even eliminate them ${ }^{29}$. The deepest controversy of the film lay in the presentation of the children's sexual intercourses with the enslaved adults, and that is why the picture was the object of Japanese and Western censorship ${ }^{30}$. However, explicit violence and atrocities are used by Terayama as the symbols of the dawn of the societal order in postwar Japan.

The critique of the changes in the Japanese society in the works of the avantgarde artists often appeared together with body transgressions. Here can be mentioned the films that show the metamorphosis of the body, stepping out the limits of the flesh (strength, power, abilities, adaptation) and that covers the topic of transgression from one form of the corporal state to another. Shinya Tsukamoto presented the horrifying fusion of the flesh and metal that resulted in creating the superior human being in his Tetsuo: The Iron Man (1989) ${ }^{31}$. The controversial transgression, obscure and shocking, can also be found in the films of other "cyberpunks," as mentioned, before Shōjin Fukui or Shigeru Izumiya. Moreover, the body, as well as sexuality themes, appeared in experimental, short productions. Here, the particular attention should be devoted to Love $(A i, 1962)$ by Takahiko Iimura. His incredibly sensual and intimate picture presents, in a huge close-up, the sexual intercourse of an undefined couple. The bodies appear on the screen as white smudges, intersected by the black shadows of the body contours, making it almost impossible to recognize the limbs at the first glimpse. Iimura's picture brings to mind the film of an American artist Barbara Hammer, who also presented the love act in the same aesthetics in her Dyketactics (1974) ${ }^{32}$. The theme of sexuality also came back as the narrations about the sexual minorities, such as in a famous Funeral Parade of Roses (Bara no sōretsu, 1969) by Toshio Matsumoto ${ }^{33}$.

Another important and controversial theme, regarding the traditional gender roles in Japanese society, was the case of femininity and social control. Except

28 Frank Jacob, "Emperor Tomato Ketchup: The Child as the Dictator of Mankind," in: The Child in Post-Apocaliptic Cinema, ed. by Debbie Olson (Lanham: Lexington Books, 2015), p. 161.

29 See: Frank, "Emperor Tomato Ketchup," p. 161.

30 After the reaction of the censorship bureau, Terayama' film was shortened from the 85 minutes of the original material to 28 minutes' version screened in Europe.

31 Mes, Iron Man, pp. 49-67.

32 Dykatactic. Barbara Hammer, USA, 1974.

33 Michael Raine, "Introduction to Matsumoto Toshio: A Theory of Avant-Garde Documentary," Cinema Journal, Vol. 51, No. 4 (2012), pp. 144-147. 
Yoko Ono ${ }^{34}$, widely recognized among the Western audience, it is also worth mentioning Mako Idemitsu ${ }^{35}$. In her works, Idemitsu focused on the meaning of the role of a mother in Japan (ex. series Great Mother, 1983-1984), the situation of the housebound housewives (ex. Kiyoko's Situation, 1989) and, what she calls, "social control" over the women's and girl's minds by providing them with constant examples of the ideal behavior, accepted by the society (Inner Man, 1972).

The artists of the first generation of the Japanese avant-garde did not restrain themselves only to the categories presented above. However, the controversy, critique of the norms, attempts to cross the boundaries of the traditional aesthetics were the important parts of their pictures, as well as the main points of their artistic programs. It can be summarized that the controversy defined the existence of the Japanese avant-garde, as the movement emerged on the wave of the critique of social norms.

\section{Thematic areas of the new avant-garde filmmakers}

The thematic areas of the new avant-garde filmmakers can be divided into two categories. The first one contains the works of the directors who are mainly interested in developing their technological skills to be able to create more advanced and visually astounding contemplation films. Their projects often revolve around abstract, quickly changing frames and surreal aesthetics, not introducing the theme directly. The visual art they present is often metaphysical and symbolic, covering topics such as the meaning of existence and human's place in the cosmic order.

One of the most notable artists, concentrated on the abstract ideas, is Takashi Makino $^{36}$, the founder and member of the Collective Plus [+]. Combining 3D techniques with the original usage of the Pulfrich effect ${ }^{37}$, he shows the visions of cosmos, generated by computer processing of the images. Among Makino's films depicting the whirling supernovas, the most popular (and most often screened)

34 More about the works and life of Yoko Ono can be found in the publication: Hans U. Obrist, Yoko Ono (New York: Distributed Art Pub Incorporated, 2009).

35 The complete list of Idemitu's films, together with short descriptions, can be found on artist's website: Mako Idemitsu, Mako Idemitsu - Media Artist, (2016): 15 Jan 2017, http://makoidemitsu.com/work-archive/?lang=en.

36 See: Takashi Makino, Makino Takashi.

37 Takashi Makino described how he used the Pulfrich effect in his film in the interview for Los Angeles Film Forum. See: “Takashi Makino: Entering a Noisy Cosmos", Los Angeles Film Forum: 30 Mar. 2016, http://www.lafilmforum.org/archive/fall-2014schedule/makino-takashi-entering-a-noisy-cosmos/. 
are Phantom Nebula (2014) and Still in Cosmos (2009). The illusion of depth he creates, based on the difference in timing of the signal, is recognized by the eyes of the audience ${ }^{38}$. As the artist states, he wants to encourage the viewers to open up for new experiences and search for an absolute through the contemplation of the abstract images ${ }^{39}$. To his account, Makino also has a film that resembles a visual diary. In 2012 (2013) Makino shows what he observed and felt during the year 2012, after the Fukushima disaster. As he indicated in the interview conducted by Julian Ross, in the film 2012 the artist wanted to show the atmosphere of the year, during which the fear of the radioactivity after the Fukushima disaster dominated the media discourse in $\operatorname{Japan}^{40}$. However, 2012 does not present the critique of the government or even the catastrophe as a political issue. The author concentrates on the mood and national grief, avoiding the controversy or direct comments on the situation. Makino felt that by preparing the film related to the catastrophe, he will have an opportunity to capture the spirit of the nation at that time ${ }^{41}$. Another artist, who focuses on showing abstract pictures of familiar, everyday objects and people, is Shinkan Tamaki ${ }^{42}$. The director uses the symbolism to undertake a game with the viewer's perception, what can be observed in his films Dying Moon (2005) or One Record on December (2007). However, the contemplation of the shapes and textures, unrecognizable for the first glimpse, does not offer the space for controversy, transgression or political critique.

The second thematic area appearing in the works of the new Japanese avantgarde and experimental artists is the role of nature in humans' lives and the peaceful coexistence of all living creatures. The directors also raise the issue of the people alienated in a modern metropolis, unable to find their way back to the joyful land of ecological utopia from the pre-industrial times. In this case, nature becomes the metaphor of the freedom, lost by the inhabitant of the sterile cities. The importance of the contact with nature became the primary interest of Rei Hayama $^{43}$, also the member of Collective Plus [+]. Her films became the reflections of what is significant for the author, as she spent her childhood living with

38 See: Kiejziewicz, “The technologies,” p. 105.

39 "Takashi Makino: Entering a Noisy Cosmos."

40 Julian Ross, “Interview: Takashi Makino," Filmcomment, Vol. 3, (Oct 2014): 15 Jan. 2016, http://www.filmcomment.com/blog/interview-takashi-makino/.

41 Ross.

42 See: Shinkan Tamaki, shinkantamaki.net, (2017): 18 Jan. 2017, http://shinkantamaki. net/about/.

43 Rei Hayama, Rei Hayama, 19 Jan. 2017, http://www.reihayama.net/. 
her parents in the forest hut ${ }^{44}$. Hayama recreates on the screen the memories of the innocent children's plays in the natural environment, which can be observed, for example, in A Child Goes Burying Dead Insects (2009). She also focuses on the beauty of nature itself and compares the industrial environment with the evergreen settings (ex. Emblem, 2012).

The problem of being lost in an urban environment again appears in the works of Kazuhiro Goshima ${ }^{45}$ and Tomonari Nishikawa ${ }^{46}$, who emphasize the overwhelming atmosphere of the detail-planned spaces of the metropolis. They also portray artificial environment as an organism powered by the infinite, mysterious energy. The cities in Goshima's and Nishikawa's films are accelerated by the shadows or the movements of the inhabitants. The uncanny atmosphere of the modern cities is connected to the discourse about the catastrophe of the humanity, caused by the excessive usage of the atomic power and rapid technological development. Goshima's empty and silent urban spaces bring to mind, deprived of the inhabitants, postapocalyptic areas (such as in Different Cities, 2006). The problem of nuclear power also appears in Tomonari Nishikawa's picture Sound of a Million Insects, Light of a Thousand Stars (2014). In this film, the author openly criticizes the Japanese government for stating that the terrain around the reactors was completely safe and encouraging the former inhabitants to come back to their premises. The controversy of Nishikawa's picture lies in the technology he adopted - the artist buried the film tape under the fallen leaves on the previously contaminated area and left it there for the nighttime. Later on, the author retrieved it with the help of the American technicians and processed (the contaminated) tape in the studio, showing the effects that the radioactive waste in the soil had on the material. Nishikawa describes the process of preparing Sound... on his website: "I buried a 100-foot $35 \mathrm{~mm}$ film negative film under fallen leaves alongside a country road, which was about 15 miles away from the Fukushima Daiichi Nuclear Power Station, for one night in June 2014. The film was exposed to the possible remaining of the radioactive materials" 47 .

As it can be observed on the presented examples of the best known new Japanese avant-garde films, it is hard to find many controversial themes among the works of the young generation of the artists. They mostly focus on the spiritual

44 Monica Delgado, Jose S. Hinojosa, “Interview: Rei Hayama," Desistfilm (8 Jul 2014): 11 Sept. 2016. http//:desistfilm.com/interview-rei-hayama/.

45 See: Kazuhiro Goshima, Kazuhiro Goshima.

46 See: Tomonari Nishikawa, Tomonari Nishikawa.

47 Tomonari Nishikawa, Tomonari Nishikawa. 
and contemplative mood, not forcing the viewer to change his perception, but gently encouraging him to reconsider the chosen problem. Moreover, the directors seem to be more interested in focusing on global issues and universal themes as urbanization, the opposition of nature versus industrialization and personal development. They also completely abandoned the discourse of the body transgressions, which was the most controversial theme of the first Japanese avant-garde film.

\section{Conclusion: Who needs controversy today?}

As Polish researcher Krystyna Wilkoszewska observes, the avant-garde can be perceived both as an anarchist movement aiming at overthrowing the existing artistic standards and as the formal experiment - the act of inventing new aesthetics ${ }^{48}$, different from the traditional art. According to the presented statement, it can be admitted that the new generation continues the postulates of the first Japanese avant-garde movement only if the new movement is perceived as the form of new aesthetics. However, taking into consideration all postulates of two generations of the filmmakers and comparing the most popular themes adopted by them, it has to be admitted that the young artists do not fully follow the path introduced by the "old masters."

Besides the noticeable rejection of the controversial themes by the new avantgarde, there are significant differences in understanding the contact with the audience. Also, the ways of distribution of the ideas and ready products (recordings, posters, results) has changed, resembling the strategies of the mainstream cinema. Moreover, it can also be noted that working inside the collectives differentiates from the practices of the "old masters." Nowadays, the groups focus on a collaborative collection of funds and focus mostly on economic aspects of this cooperation. However, as Takashi Makino admits, sharing ideas also plays a major role in the collective work.

Summing up, the young generation of the Japanese avant-garde directors continues the postulates of the "old masters" only on the ground of the aesthetic experiments with the "form." The controversy that played an important part in the art of the previous generation is no longer needed in the new independent, experimental films, as the objectives and themes have changed. The meditation and slow, thorough contemplation of the social problems became the most important and recurring theme of the new avant-garde. Instead of trying to alter

48 Wiek awangardy [The Age of Avant-Garde], ed. Liliana Bieszczad (Kraków: Universitas, 2006), p. 9. 
the viewer's point of view by shocking him, the artists offer the audience some relief, a peaceful rest from everyday noise and mainstream films that focus on the attraction, shock and transgressions.

\section{Bibliography}

Berghaus, Günter. Avant-garde Performance. New York: Palgrave Macmillan, 2005. Collado, Esperanza. “Takahiko Iimura in Interview." Experimental Conversations, Vol. 5, 2009/2010, http://www.experimentalconversations.com/article/ takahiko-iimura-in-interview/ (20 Nov. 2016).

Delgado, Monica and Hinojosa, Jose S. “Interview: Rei Hayama." Desistfilm, 8. Jul. 2014. http//:desistfilm.com/interview-rei-hayama/ (11 Sept. 2016).

Eckersall, Peter. Performativity and Event in 1960s Japan. City, Body, Memory. New York: Palgrave Macmillan, 2013.

Goshima, Kazuhiro. Kazuhiro Goshima. 2013. http://www.goshiman.com/ (17 Jan. 2017).

Hayama, Rei. Rei Hayama. http://www.reihayama.net/ (19 Jan. 2017).

Idemitsu, Mako. Mako Idemitsu - Media Artist. 2016. http://makoidemitsu.com/ work-archive/?lang=en (15 Jan. 2017).

Iimura, Takahiko. The Collected Writings of Takahiko Iimura. Maryland: Wildside Press LLC, 2007.

Ito, Takashi. "Biographical Essay." Takashi Ito. http://www.imageforum.co.jp/ito/ profile.html (15 Dec. 2016).

Jacob, Frank. "Emperor Tomato Ketchup: The Child as the Dictator of Mankind." In: The Child in Post-Apocaliptic Cinema, ed. Debbie Olson, Lanham: Lexington Books, 2015, pp. 153-169.

Kiejziewicz, Agnieszka. "The technologies of experimental Japanese filmmakers in the digital era." Transmissions: The Journal of Film and Media Studies, Vol. 1, No. 1, 2016, pp. 99-114.

Kluszczyński, Ryszard W. Awangarda. Rozważania teoretyczne. [Avant-garde. Theory] Łódź: Wydawnictwo Uniwersytetu Łódzkiego, 1997.

Lewis, Graham. "Pinnochio 964, Death Powder and the Post-Human Condition." In: Japanese Horror Cinema, ed. Jay McRoy, Edinburgh: Edinburgh University Press, 2005.

MacDonald, Scott. "An Interview with Taka Iimura." Journal of the University Film Association, Vol. 33, No. 4, 1981, pp. 21-44.

Makino, Takashi. Makino Takashi.2015, http://makinotakashi.net/. (15 Dec. 2016). 
Makino, Takashi. Hayama, Rei and Tamaki, Shinkan. "Mostra de Cinema Periferico." Youtube, 6. Jun. 2014, https://www.youtube.com/watch?v=SUWJRVu77c (17 Dec. 2016).

Mellen, Joan. Voices from the Japanese Cinema. New York: Liveright, 1975.

Morita, Norimasa. "Avant-Garde, Pastiche, and Media Crossing: Films of Terayama Shuji." Waseda Global Forum, Vol. 3, 2006, pp. 53-58.

Mes, Tom. Iron Man. The Cinema of Shinya Tsukamoto. Godalming: FAB Press, 2005.

Mes, Tom and Sharp, Jasper. The Midnight Eye Guide to New Japanese Film, Berkeley: Stone Bridge Press, 2005.

Munroe Hotes, Catherine. “Takashi Ito's Film Works.” Midnighteye. 2010. http:// www.midnighteye.com/reviews/takashi-itos-film-works/ (17 Dec 2016).

Nishikawa, Tomonari. Tomonari Nishikawa. 2017. http://www.tomonarinishikawa. com/ (10 Jan. 2017).

Obrist, Hans U. Yoko Ono. New York: Distributed Art Pub Incorporated, 2009.

Plus Documents 2009-2013, ed. Takashi Makino, Indianapolis: Engine Books, 2014.

Raine, Michael. "Introduction to Matsumoto Toshio: A Theory of Avant-Garde Documentary." Cinema Journal, Vol. 51, No. 4, 2012, pp. 144-147.

Rees, Al. History of Experimental Film and Video. London: British Film Institute, 1999.

Ridgely, Steven C. Japanese Counterculture. The Antiestablishment Art of Terayama Shuji. Minneapolis: University of Minnesota Press, 2010.

Ross, Julian. "Interview: Takashi Makino." Filmcomment, Vol. 3. 2014. http://www. filmcomment.com/blog/interview-takashi-makino/ (15 Jan. 2016).

Ross, Julian. "Projection as Performance: Intermediality in Japan's Expanded Cinema." In: Impure Cinema: Intermedial and Intercultural Approaches to Film, eds. Lucia Nagib and Anne Jerslev, London: I.B. Tauris, 2013, pp. 249-267.

Sas, Miryam. Experimental Arts in Postwar Japan: Moments of Encounter, Engagement, and Imagined Return. Cambridge: Harvard East Asia Monographs, 2011.

Sasaki-Uemura, Wesley M. Organizing the Spontaneous: Citizens Protest in Postwar Japan. Honolulu: University of Hawaii Press, 2001.

Schedelbauer, Sylvia. "Poetics of an Urban Darkness: Takashi Ito's Spectral Cinema." Language Constellations, Vol. 20. 2011. http://othercinema.com/ otherzine/archives/index.php?issueid=25\&article_id=121. (10 Dec. 2016). 
Schilling, Mark. “Japanising the Dark Side: Surrealism in Japanese Film." In: The Unsilvered Screen: Surrealism on Film, eds. Graeme Harper and Rob Stone, London: Wallflower Press, 2007, pp. 134-142.

Scholz-Cionca, Stanca. Japanese Theatre and the International Stage. Leiden: Brill, 2001.

Shaneen, Marianne. “Takashi Makino’s 2012.” BOMB - Artist in Conversation Magazine, Vol. 130, 2015, http://bombmagazine.org/article/2000042/takashimakino-s-em-2012-em (11 Dec. 2016).

Sharp, Jasper. Behind the Pink Curtain. The Complete History of Japanese Sex Cinema. Godalming: FAB Press, 2008.

Sorgenfrei, Carol F. Unspeakable Acts: The Avant-garde Theatre of Terayama Shuji and Postwar Japan. Honolulu: University of Hawaii Press, 2005.

Standish, Isolde. Politics, Porn and Protest. Japanese Avant-Garde Cinema in the 1960s and 1970s. New York: Continuum, 2001.

"Statistics of Film Industry in Japan." Motion Pictures Producers Association of Japan, Inc. http://www.eiren.org/statistics_e/. (11 Jan. 2017).

Tamaki, Shinkan. shinkantamaki.net. 2017. http://shinkantamaki.net/about/. (18 Jan. 2017).

Terayama, Shuji. "Manifesto." The Drama Review, Vol. 19, No. 4, 1975, pp. 84-85.

In: Wiek awangardy, [The Age of Avant-garde], ed. Liliana Bieszczad, Kraków: Universitas, 2006.

Vacheron, Joel, "Kazuhiro Goshima: After the Metabolic Cities." 12th Biennial of Moving Images in Geneva, JRP | Ringier, 2007, pp. 42-43. http://joelvach eron.net/wordpress/wp-content/uploads/2007/11/Goshima-12th-BIM2.pdf (10. Feb. 2018). 



\title{
Janina Falkowska
}

Western Arts and Humanities, Canada, and University

of Economics and Humanities in Bielsko-Biala, Poland

\section{Mockumentary cinema and its political might: Self-reflexivity and carnivalesque in the films of Michael Moore and Sacha Baron Cohen}

\begin{abstract}
The topic of this chapter is "mockumentary" cinema. Called by Timothy Corrigan "essay films," such documents "interpolate a subjective and investigative agency within the footage of media events from a variety of angles." Michael Moore and Sacha Baron Cohen make their films in the manner of mocku-documentary, each of them using their investigating personae to remake the news across "their own image and agency." Eventually, they create politically powerful boisterous carnivalesque films far exceeding the effect of a mere presentation of fact. I am especially interested in the ways these films cross genre boundaries and emerge as a separate small cinema with its own choice of means, among which the narrator seems to play the most effective part in producing a powerful emotional response to this kind of film.
\end{abstract}

Keywords: Mockumentary, carnivalesque, Michael Moore, Sacha Baron Cohen, essay film

Small cinema is usually described as cinema of small nations or produced in small countries. However, we have observed cinemas defined by particular characteristics or formats emerging in one country or one geographical location and then spreading over continents, imitated and emulated by others elsewhere. French New Wave and the Dogma Movement are obvious such examples in fiction cinemas, while in documentary cinema, it is mockumentary and self-reflexive cinema that merit similar attention.

In this chapter, I will concentrate on documentary cinema and its specific variety: mock-documentary film. Being a variation of documentary film, on the one hand, it embodies the genre's uniqueness in content and form but, on the other hand, it symbolizes the enigmatic nature of any other genre categories.

In essence, documentary is a nonfiction film that reenacts, comments on, or generally retells history. It is entirely factual, even though it may also state opinions about the facts it presents. Conversely, mock-documentary underscores the genre's origins in copying a preexisting form in an effort to construct a film form that the audience is assumed to be familiar with. A mock-documentary subverts 
or ridicules by imitation, applies critical distance, and incorporates documentary for entertainment's sake. However, a mock-documentary can also exert political criticism through sheer power of images and the antics of the commentator or narrator presented in it.

My attention to this type of documentary grew from a number of research interests I have harbored over the years: interest in categorization, film genres, and subversion of the aforementioned through disruptive practices of mockery and self-reflexive distance. Whenever a carefully designed category or rule organized the principles of genre in neatly defined boundaries, sheer imagination of the director, the outrageousness of major protagonists or narrators in the films uprooted the categories and created a highly welcome chaos in the vein of Mikhail Bakhtin's carnivalesque.

How to then treat these kinds of documentaries in which the personae of the commentators take over and go beyond just reporting on the true events? It is the persona that dominates the message, and not the events themselves. In this sense, such films could be treated as particularly obnoxious essay films in which the intrusive selves of the directors overpower the truth value of the presented events. In his book The Essay Film: From Montaigne, After Marker, Timothy Corrigan introduces a definition for the essay film as one revealing the following characteristics, among others: "If both verbal and visual expression can commonly suggest the articulation or projection of an interior self into an exterior world, essayistic expressivity describes (...) a subjection of that instrumental or expressive self to a public domain, often personified as a shifting and disembodied 'you."'1

In her article, "The Essay Film: Problems, Definitions, Textual Commitments," Laura Rascaroli notes several other factors that appropriate a film to be an essay film. After thorough research of many authors writing on the subject, she identifies the following aspects revealed by an essay film:

- disrespect for traditional boundaries

- self-reflectivity and self-reflexivity

- subjectivity and its foregrounding

- incorporation of the act of reasoning in the film

- transgressivity, digressivity, playfulness, contradictory and political nature

- a mode of personal reflection

- self-conscious style

- presence of words, in the form of a text, either spoken, subtitled or intertitled

1 Timothy Corrigan, The Essay Film: From Montaigne, After Marker (New York: Oxford University Press, 2011), p. 33. 
- strong presence of the enunciator in the "expository" mode, "in which we find a 'voice of God' commentary directed toward the viewer"

Michael Moore and Sacha Baron Cohen have made such films and have performed in them, respectively. Their films exceed expectations and are a source of constant delight but also introduce serious critique. One of the techniques that they effectively apply is the use of their own investigative personae to remake the data according to their own image and agency.

In the case of Michael Moore, it is his persona that generates resistance, spite (as expressed by many authors of critical articles about him), and adds to the explosive content of the film, which probably would not have been as fiercely debated and perceived as quasi-truthful if it were presented as more toned down in content and unmediated by an ill-tempered journalist. For instance, the presentation of events in Roger \& Me (1989), Fahrenheit 9/11 (2004), Sicko (2007), and Where to Invade Next (2015) was generally described as manipulative and not to be trusted.

Most authors refer to Moore's narrative persona as, either by appearing in the films or by narrating them off-screen, enriching the films' content with a particular mixture of pathos, pugnacity, and spite. His pseudo-documentaries become mockumentaries because they mimic the genre and turn it "upside down" to expose its authoritarian nature and questionable "truth value."

Corrigan states that Moore reaches the pinnacle of notoriety precisely because his subjective self gains the upper hand in the message he transmits. "Despite his often outlandish and cartoonish posturing - or, more accurately, because of those poses - Moore and his films effectively mimic and ironize the strategies of conventional news reportage as efforts, I would argue, to return the ideological risks of subjective thinking to the streets of public events."

Instead of realizing Moore's films potential for more insightful analysis of their ideological, historical, and social content, the authors of many publications written on "the case of Michael Moore" remain palpably offended by the content and Moore's unsubstantiated spite and accusations and react emphatically to the films.

The excerpts from the articles, written by Tony McKibbin, Christopher Hitchens, and Louise Spence, respectively, clearly illustrate the kind of affective reaction Moore elicits, resulting in an obvious discomfort that viewers experience when they watch Michael Moore's films. For instance, on Moore's Fahrenheit 9/11, Tony McKibbin states,

2 Laura Rascaroli, “The Essay Film: Problems, Definitions, Textual Commitments," Framework, Vol. 49, No. 2 (Fall 2008), pp. 24-38.

3 Corrigan, Essay Film, p. 173. 
Moore's documentary is not a film of political thought (à la Errol Morris' recent The Fog of War [2003]), but a film of insistent righteousness. B. Ruby Rich is absolutely right when she says in her Sight and Sound piece that "experience is more valued than evidence; appeals to emotion tend to succeed over the most perfectly crafted argument."

Moore is so hysterically insistent that he leaves skeptics feeling naive. On the one hand, you come away from the film believing any attempt at democracy in America is a waste of time and energy, and on the other, that George Bush's incompetence is completely responsible for a decline of the American empire. ${ }^{5}$ When Hitchens and others say that Moore wants it all ways, we merely have to suggest that he wants to mix genres in such a manner that he can offer some very intriguing footage, and seeks to win an argument that is never really logically expressed. ${ }^{6}$

Not surprisingly, the lack of logic and the presence of emotion in Moore's direct address to the audiences has been politically effective as it brought about an incredible debate in the Senate. Robert Brent Toplin reports,

Democratic Senator Barbara Boxer, evidently affected by the emotion-laden footage at the beginning of Fahrenheit 9/11 showing that no senator had been willing to support a challenge to the 2000 presidential election results, agreed to back such a challenge in 2005 . This action, dubbed Boxers Rebellion, drew Senators into nearly four hours of contentious debate. The nightly television programs of January 7 brought lively commentary on the matter and the politics of Michael Moore. ${ }^{7}$

An especially insightful article about Michael Moore's films has been written by Louise Spence ${ }^{8}$ who focuses on Moore's persona and the way it influences his films' reception. She specifically focuses on the following matters:

1. The role of authority and intellectual skills

2. Moore's reinforcement and reiteration of himself and only himself

3. Rejection of documentary skills - he is scruffy, tough, slouchy

4 Tony McKibbin, The Thickening Centre: Fahrenheit 9/11, Senses of Cinema, No. 33 (October 2004), accessed 10 June 2016, http://sensesofcinema. $\mathrm{com} /$ ?s=The+Thickening+Centre.

5 McKibbin, The Thickening Centre.

6 Christopher Hitchens, "Unfairenheit 9-11: The Lies of Michael Moore," Slate (21 June 2004), accessed 16 September 2004, http://www.slate.com/articles/news_and_ politics/fighting_words/2004/06/unfairenheit_911.html.

7 Robert Brent Toplin, "The Long Battle Over Fahrenheit 9/11: A Matter of Politics, Not Aesthetics," Film and History, Vol. 35, No. 2 (2005), p. 8.

8 Louise Spence (with Vinicius Navarro), "Working-Class Hero: Michael Moore’s Authorial Voice and Persona," The Journal of Popular Culture, Vol. 43, No. 2 (2010), pp. 368380 . 


\section{Romanticism and nostalgia}

5. Persona as evidence

Louise Spence is especially critical of Moore in the entire article, not changing her approach even upon reflection of the possibility that the Moore persona functions as a character in a romantic comedy in which the rhetoric of comedy moves toward a happy ending. In a pugnacious comedy, every move and trick serves as a proper act in the comedy including a carnivalesque intolerable behavior of the protagonist.

This article looks at Michael Moore's persona - the aggrieved, aggressive maverick, the know-it-all who knows nothing - to explore the idea of authorial voice and persona in nonfiction filmmaking. Michael Moore, the everyman, the ordinary guy in the gravystained tee shirt whose job it is to look after our interests, seems to be the authority that is no better than we are, but who has more guts. Smart, but appearing to be unschooled, his belligerent air of thwarted entitlement and his anti-intellectualism point to a contradictory set of values and viewpoints, paternalistic authority on the one hand and rugged delinquency on the other, that are sometimes hard to splice together. $(. . .)^{9}$

His rejection of the documentary label seems to be tied to his rejection of, and disrespect for, the dry authority of documentaries. Yet his persona feeds off the glow of the authority it condemns. Moore has a self-mocking tenor to his persona - setting up a double edged humor. He may be eccentric and weird, but never as eccentric or weird as the others he encounters. He gets a lot of laughs out of nursing his distrust of people in authority and with power, "stupid white men."

Almost all the authors of publications about Moore reject his persona as a legitimate author of a documentary film but rather present him as someone who is vulgar, furious, and not a good material for any presentation or performing skills.

In my opinion, however, what Michael Moore really does is work as a subversive clown who wants to challenge the system in place to persuade people to contemplate reality. In this sense, he fits into the idea of carnivalesque, a Bakhtinian idea of the temporary destruction of order in place during a carnival.

Consequently, Michael Moore as the documentary filmmaker is a king of fools or a holy fool so loved by figures of authority (like kings or princes) who could see in him a twisted rendering of their own personae. The members of the audience also recognized this. They understood the climate of constant rebellion in documenting reality, whereby the presented truth becomes the subject of the carnivalesque itself that defines the political life today.

9 Spence, "Working-Class Hero," p. 368.

10 Spence, "Working-Class Hero," p. 371. 
Disrespect for the figures of authority, disregard for the lawful processes, the blending of the public and the private expressed in social media such as Facebook, Instagram and Twitter by public and private figures alike, all these opinions treated as equally important, truthful, and wise have led to the outrageous carnivalization of society in which disorder rules, everybody and everything are questioned in both hilarious and demagogic ways.

This kind of carnivalization is also present in a well-known film directed by Larry Charles with Sacha Baron Cohen, a renowned British comedian. The film is a mockumentary following the misadventures of Borat, a Kazakh journalist who "leaves his native Kazakhstan to travel to America to make a documentary. As he zigzags across the nation, Borat meets real people in real situations with hysterical consequences. His backward behavior generates strong reactions around him exposing prejudices and hypocrisies in American culture. In some cases, Borat's interview subjects embrace his outrageous views on race and sex by agreeing with him, while others attempt to offer a patriotic lesson in Western values."11

In Borat, Sacha Baron functions as a "go between" among an uninitiated audience from Kazakhstan, the nation he represents, and American society he tries to explore and understand (and report about it). He engages interview techniques in an outrageous way challenging the interviewees' sense of dignity and wholeness. Pretending to be an uncivilized Kazakh, he hilariously questions the assumed political correctness in approaches to gender, politics, and media personae.

We are compelled to admit, however, that Borat is a mockumentary in a different sense compared to Michael Moore's films. Although it shows data gathering and interviews performed by the main character, the outrageous nature of questions and behaviors elicited by Borat creates a comedic effect not anticipated by the interviewees in the film nor its audiences.

On top of the difference between the types of documentary these films represent, we face a confusion related to the authorial persona in both films. Moore never denies that he is the author, the director, and the performer in the film. Conversely, Sacha Baron Cohen is only a performer in the film directed by Larry Charles, who plays the part of the naive and uneducated journalist from the far, far East somewhere in Asia.

A lot has been written about Borat. In fact, an entire edition of Slavic Review (Vol. 67, No. 1, Spring 2008) has been published about the film under the title "'Borat': Selves and Others." Authors discuss the film in the context of national

11 Rotten Tomatoes, "Borat Film Review," accessed 10 Oct 2016, https://www.rottento matoes.com. 
identity, "the other," mock-documentary and other areas. From my point of view and for my purposes, the most interesting analysis has been presented by Natalie Kononenko and Svitlana Kukharenko. Both authors, of Eastern European background, shed new light on the film. Kononenko and Kukharenko, in their article "Borat the Trickster: Folklore and the Media, Folklore in the Media," 12 present Borat as a quintessential trickster, a persona well known in the literature and art of Slavic nations.

Narcisz Fejes, on the other hand, treats Borat as a Dracula-like character who, on his way of discovery of customs and mores of America, tries to colonize the land and impose his atavistic and primitive values on the land of "the civilized." In his essay "Feared Intrusions," Fejes concludes his intricate and meticulous analysis with the declaration that Borat, in fact, exposed American quasi-values to a greater degree than he showed his lack of manners and understanding in a civilized world. As Fejes states,

Borat's ability to expose what hides behind the American characters' teaching fervor as well as a veneer of multiculturalism and liberalism can make the Western audience somewhat unsettled and feel prompted to prepare for Borat's - or, Sacha Baron Cohen's next trick and uncanny performance. ${ }^{13}$

In both cases, of Moore and Sacha Baron Cohen, we deal with explosive authorial personae, each of which are realized in a different way, and impose their own interpretation on the presented reality. While Moore is highly critical of the actors in his documentary dramas, Sacha Baron Cohen wants to amuse people in a sarcastic and abusive way. In both cases of authorial creativity, they disrupt order and subvert decency in a carnival's way presenting subjects as totally ridiculous.

In the introduction to Rabelais and His World, Bakhtin voices one of the most important statements that has defined his career as one of the most important theoreticians of the twentieth century:

As opposed to the official feast, one might say that carnival celebrated temporary liberation from the prevailing truth and from the established order; it marked the suspension of all hierarchical rank, privileges, norms, and prohibitions. Carnival was the true feast of time, the feast of becoming, change, and renewal. It was hostile to all that was immortalized and completed.

12 Natalie Kononenko and Svitlana Kukharenko, "Borat the Trickster: Folklore and the Media, Folklore in the Media," Slavic Review, Vol. 67, No. 1 (Spring 2008), pp. 8-18, accessed 09 September 2017, http://www.jstor.org/stable/27652761.

13 Narcisz Fejes, "Feared Intrusions: A Comparative Reading of Borat and Dracula," The Journal of Popular Culture, Vol. 44, No. 5 (2011), p. 1007. 
The suspension of all hierarchical precedence during carnival time was of particular significance. Rank was especially evident during official feasts; everyone was expected to appear in the full regalia of his calling, rank, and merits and to take the place corresponding to his position. It was a consecration of inequality. On the contrary, all were considered equal during carnival. Here, in the town square, a special form of free and familiar contact reigned among people who were usually divided by the barriers of caste, property, profession, and age. The hierarchical background and the extreme corporative and caste divisions of the medieval social order were exceptionally strong. Therefore, such free, familiar contacts were deeply felt and formed an essential element of the carnival spirit. People were, so to speak, reborn for new, purely human relations. ${ }^{14}$

We find here a characteristic logic, the peculiar logic of the "inside out," of the "turnabout," of a continual shifting from top to bottom, from front to rear, and of numerous parodies and travesties, humiliations, profanations, and comic crownings and uncrownings. A second life, a second world of folk culture is thus constructed: it is to a certain extent a parody of the extra carnival life, a "world inside out." ${ }^{15}$

Both Michael Moore and Sacha Baron Cohen respond to these characteristics. They uncrown figures of authority, and the arrogance of the United States (supposedly "the best country in the world"). They tear their subjects' self-assuredness to shreds by exposing their weaknesses and lack of logical argument. They turn into self-reflective fools pretending to know nothing but in fact performing their mockumentary personae to leave audiences shaken to the core.

\section{Bibliography}

Bakhtin, Mikhael. Rabelais and His World. Transl. Helene Iswolsky. Bloomington: Indiana University Press, 1984.

Corrigan, Timothy. The Essay Film: From Montaigne, After Marker. New York: Oxford University Press, 2011.

Fejes, Narcisz. "Feared Intrusions: A Comparative Reading of Borat and Dracula." The Journal of Popular Culture, Vol. 44, No. 5, 2011, pp. 992-1009.

Fleischmann, Aloys. "The Rhetorical Function of Comedy in Michael Moore's Fahrenheit 9/11." Mosaic, Vol. 40, No. 4, 2007, p. 69+. Academic OneFile http:// www.umanitoba.ca.proxy1.lib.uwo.ca/mosaic/ (Accessed 11 October 2017).

Porton, Richard. "Weapon of Mass Instruction: Michael Moore’s Fahrenheit 9/11." Cineaste, Vol. 29, No. 4, Fall 2004, pp. 3-7.

14 Mikhael Bakhtin, Rabelais and His World, transl. Helene Iswolsky (Bloomington: Indiana University Press, 1984), p. 10.

15 Bakhtin, Rabelais and His World, p. 11. 
Rascaroli, Laura. "The Essay Film: Problems, Definitions, Textual Commitments." Framework, Vol. 49, No. 2, Fall 2008, pp. 24-47.

Natalie Kononenko and Svitlana Kukharenko. Borat the Trickster: Folklore and the Media, Folklore in the Media in "Borat": Selves and Others. Slavic Review, Vol. 67, No. 1 Spring 2008. Published by: Association for Slavic, East European, and Eurasian Studies; Cambridge University Press., pp.8-18. http://www.jstor. org/stable/27652761 (Accessed 09 October 2017)

Spence, Louise (with Vinicius Navarro). "Working-Class Hero: Michael Moore's Authorial Voice and Persona." The Journal of Popular Culture, Vol. 43, No. 2, 2010, pp.368-380.

Toplin, Robert Brent. “The Long Battle Over Fahrenheit 9/11: A Matter of Politics, Not Aesthetics." Film and History, Vol. 35, No. 2, 2005, pp. 8-10. (Accessed 11 October 2017).

\section{Internet sources}

Hitchens, Christopher. "Unfairenheit 9-11: The Lies of Michael Moore," Slate, Vol. 21 June 2004. http://www.slate.com/articles/news_and_politics/fighting_ words/2004/06/unfairenheit_911.html (Accessed 16 September 2004)

McKibbin, Tony. “The Thickening Centre: Fahrenheit 9/11." Senses of Cinema, October 2004, No. 33. http://sensesofcinema.com/?s=The+Thickening+Centre (Accessed 10 June 2016)

Rotten Tomatoes (2006). "Borat Film Review." https://www.rottentomatoes.com (Accessed 10 October 2016) 



\section{Part 5: Aesthetics of New Small Films}





\title{
Phil Mann \\ University of St Andrews
}

\section{De-centered subversion: Hukkle and the challenging of revisionist historiography}

\begin{abstract}
This chapter explores how Hungarian filmmaker György Pálfi, in his debut feature film Hukkle (2002), challenges restorative nostalgia in post-communist Hungary. Through the film's penetrative and, at times, subterranean cinematography, Pálfi creates a visual metaphor inviting his audience to look beyond the surface of the film's ostensibly idyllic rural imagery to reveal a more disagreeable reality that lies beneath this façade. I argue that Hukkle's aesthetic constitution serves as a metaphor used to confront postcommunist nostalgia, suggesting a need to challenge the rose-tinted myths of collective memory and engage with the darker issues of the past that underlie the more palatable and socially agreeable renderings of history that have come to dominate contemporary historical discourse in Hungary.
\end{abstract}

Keywords: Hukkle, Pálfi, Hungary, post-communism, history, memory, political myths, restorative nostalgia

In his winning proposal for the design of Budapest's Memento Park (Szoborpark) ${ }^{1}$, Hungarian architect Ákos Eleőd stated that: "Every violent form of society formalises the need and the right to reanalyse, touch up and appropriate their own past in order to shine favourable light on the 'historical necessity' of their regime. Democracy is the only regime which is capable of looking back to its past, with all its mistakes and wrong turns, with its head up" ${ }^{2}$. Eleöd speaks of the potential for objective historical dialogue that democracy accorded Hungary following transition. Yet, despite the renewed possibility for unbiased public discourse, history in post-communist Hungary has been a highly divisive area of contemporary society, party to various political and social manipulations with political myths propagating over honest dialogue and genuine efforts to come to terms with the traumas of recent memory. The reasons for this are manifold; however, it is not my intention to address these matters here. Instead, my interests lie in the ways in which

1 Memento Park is an outdoor museum housing communist-era public sculptures and monuments. The museum is situated on the outskirts of the Hungarian capital.

2 Quoted in Ákos Réthly, In the Shadow of Stalin's Boots: Visitor's Guide to Memento Park (Budapest: Private Planet Books, 2010), p. 6. 
György Pálfi's debut feature Hukkle (2002) scrutinizes history, myth and collective memory in contemporary Hungary. In this chapter, I propose to examine how the film confronts revisionist historiography in post-communist Hungary, history built upon therapeutic values operating in response to the hardships of transition and the disillusionment of life under the new political and economic systems.

Since its release, Hukkle has perplexed many who have sought to categorize it. The film has been described as at once an ethnography, a nature documentary, a dark comedy and a detective thriller ${ }^{3}$. Told using minimal dialogue, amplified audio and probing cinematography, the film explores a remote Hungarian village which, at the outset, appears idyllic; cinematographer Gergely Pohárnok captures this seemingly bucolic environment in penetrative detail, capturing the unseen and unheeded lives of the flora and fauna that initially appear to live in symbiosis with the human village dwellers. However, as the film progresses we find that a series of ominous murders have been taking place. Among the collection of meticulously detailed rural imagery, it emerges that the womenfolk are systematically poisoning their spouses and kin. A local detective investigates, but despite closing in on the truth, he is ultimately unable to put a stop to the women's horrific deeds. At the film's conclusion, the only men that remain in the village are bachelors, and the final scene takes place at a wedding, suggesting that another victim has been ensnared.

Despite Hukkle's contemporary setting, the film is based upon actual historic events that took place during the 1920s in the Tiszazug region of the Great Hungarian Plains (Alföld). It was revealed that for over a decade women had been poisoning both babies and elderly men deemed to no longer have any practical worth to the community. As the police learned of what had transpired and the women went to trial, their misdeeds were stifled from the public sphere. The

3 Congruously, the film evokes comparisons to a wide variety of international films. Hukkle exhibits the intricately elaborate aesthetics of French filmmaker, Jean-Pierre Jeunet, as seen in films such as Delicatessen (Jeunet and Marc Caro, 1991) and Le Fabuleux Destin d'Amélie Poulain/Amélie (2001). The film's documentary approach and vignette style depiction of the daily lives of a small insular community is reminiscent of Ermanno Olmi's L'albero degli zoccoli/The Tree of the Wooden Clogs (1978). The emphasis placed upon the local flora and fauna recalls Claude Nuridsany and Marie Pérennau's documentary, Microcosmos: Le peuple de l'herbe/Microcosmos: The Grass People (1996). Hukkle also shares the ambiguous suggestion of murder akin to Michelangelo Antonioni's Blow-Up (1966) and even incorporates stylistic parallels to Dziga Vertov's Chelovek s kino-apparatom/Man with a Movie Camera (1929). 
courts treated the incidents as distinct, unconnected cases, and in many instances trials were delayed by years to downplay the enormity of the crimes ${ }^{4}$.

By rendering this suppressed historical episode cinematically, Hungarian film scholar György Kalmár suggests that Hukkle "fills the void left by the silences of official history." In concordance with Kalmár, I argue that Hukkle may indeed be examined through the discourse of counter memory. However, I would also suggest that the film simultaneously focuses upon surrogate historical memories. I argue that Hukkle examines the constructed nature of post-communist historical remembrance and does so by utilizing the discourse of intercultural cinema. Laura U. Marks in The Skin of the Film: Intercultural Cinema, Embodiment, and the Senses (2000) states that: "[a]s in many intercultural films and videos, the act of excavation performed by these works is primarily deconstructive, for it is necessary to dismantle the colonial histories that frame minority stories before those stories

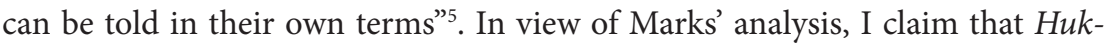
kle deconstructs therapeutic forms of historical memory, memory operating in response to post-communist fragmentation, renewed fears surrounding national death (nemzethalál) resulting from the rising prominence of global supranationalism and the continued search for an agreeable form of national identity following the collapse of communism.

Hukkle presents the act of deconstruction metaphorically, through the representation of the rural. From the outset, village life is presented as idyllic. However, over the course of the film, Pálfi destabilizes this romanticized image, slowly accentuating the dark secrets that lurk beneath the surface of the film's ostensibly bucolic pastoral setting. In doing so, I argue that Hukkle symbolically challenges common conceptions of national history in post-communist Hungary. By depicting an overly sentimentalized vision of rural life, Hukkle symbolically transforms the rural into a site of restorative nostalgia, to use Svetlama Boym's term.

Boym argues that restorative forms of nostalgia emphasize a return to origins,

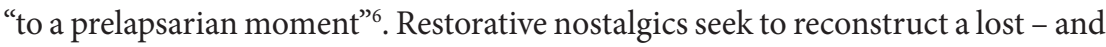
often mythicized - homeland and do so by glorifying restored and/or invented traditions. Boym claims that restorative nostalgia frequently lies at the heart of

4 See Bodó (2002) and Kalmár (2013) for further details.

5 Laura U. Marks, The Skin of the Film: Intercultural Cinema, Embodiment, and the Senses (Durham, North Carolina and London: Duke University Press, 2000), p. 25. While Hukkle does not necessarily focus upon a colonial history, the film's challenge to dominant forms of historical memory nevertheless draws parallels to the motivations of intercultural filmmakers.

6 Svetlana Boym, The Future of Nostalgia (New York: Basic Books, 2001), p. 49. 
nationalist discourse and this is no more evident than in the politics of Hungarian populist István Csurka. Csurka has "claim[ed] to fight for the preservation of the Hungarian soul against the soiling influence of Western symbols and values", drawing upon pre-communist populist/urban cleavages and resurrecting the discourse of the populist writers (népi írok) of the inter-war period. Indeed, Csurka has repeatedly positioned Hungary's urban centers as sites of anti-Hungarian cosmopolitanism, declaring the essence of the Hungarian soul to instead lie in the nation's rural heritage and the traditions of its peasantry. Consequently, postcommunist Hungary has witnessed a romantic revival of peasant culture and völkisch traditionalism ${ }^{8}$. I argue that Hukkle's Arcadian representation of rural Hungary draws on these contemporary trends, transforming the landscape into an evocative site of collective memory and nostalgia.

Indeed, the film's opening firmly establishes the countryside as a highly romanticized site of nostalgia. Following the surfacing of the snake that opens the film, the viewer is presented with an establishing shot of the village 9 . Quaint white cottages sporadically dot the lush green valley as the surrounding hills cast long shadows. We hear birds singing and dogs barking and, rather curiously, the echoed sound of a man hiccupping. The hiccupping man (Ferenc Bandi) is soon made known to us as he fills a jug with milk and takes a seat outside his house where he proceeds to watch the world go by. As his hiccups continue, the image cuts to a close-up shot of ants scurrying around the bench on which he sits, which creaks and tilts with every hiccup. A goose stretches its head through a fence to reach food; a cat yawns and stretches while idly grooming itself; a cricket leaps at the sound of the man's hiccups; a boy herds goats from his bicycle while another cyclist passes; the amplified audio accentuating the sound of rusty chains. A horse and cart rides by the hiccupping man, the coachman asleep at the helm; sheep nonchalantly graze in the field while a young shepherd sits under a tree with her dog and listens to her personal stereo. A ladybird lands on her chest and walks up the wire of her headphones as she basks in the sun. She gathers it in her hand and closely examines it as it crawls over her fingers. An elderly woman picks flowers, singing to herself under the observation of a rabbit and later a stalk. The stalk then takes flight and the image cuts to an aerial shot of the village and the surrounding

7 Vladimir Tismaneanu, Fantasies of Salvation: Democracy, Nationalism and the Myth in Post-Communist Europe (Princeton, New Jersey: Princeton University Press, 1998), p. 84.

8 See Hockenos (1993), Némedi (1995) and Kiss (2002) for more detailed insight into the romanticizing of the peasantry in Hungarian ideology.

9 Hukkle was shot in the village of Ozora, situated in the north of Tolna County. 
fields. Such idyllic rural imagery continues throughout the film and establishes a sense of Arcadia akin to that disseminated in Golden Age mythology.

Village life is presented as a natural and organic way of living, a place of simple virtues, tranquility and plenitude. The repeated shots of nature alongside those of the village dwellers suggest a harmonious relationship between man and beast. The film's emphasis on the local wildlife also bestows upon the film an Edenic quality. Animals have been recurrent symbols in the representation of the Garden of Eden as a means of suggesting both the abundance of the land bequeathed to man by God as well as a sense of harmony. This is evident in the work of artists such as Jan Brueghel whose The Garden of Eden with the Fall of Man (1613) foregrounds various animals, placing predator and prey side by side, as a vision of paradise. Pálfi's repeated emphasis on the local flora and fauna, likewise, presents a utopian vision of village life.

Thus, the opening sequences present an image of the rural congruous to that celebrated and elevated in revisionist histories and restorative myth; that of a Golden Age, an Eden. However, having established such a vision of rural life, Pálfi then proceeds to destabilize it. Destabilization is achieved through the discourse of intercultural counter cinema. Laura U. Marks suggests that minor cinema, that is, cinema wishing to both challenge and expand the limits of established and accepted historical discourse, must do so within the parameters of the prevailing discourse it wishes to challenge ${ }^{10}$. She asserts that "[d]iscourses are not only restrictive but enabling. While they limit what can be said, they also provide the only language in which to say it. In order to find expression, emerging thoughts and things must speak in the terms of the discourses that are established, though at the same time they break away from them"11.

Dominant cultural, political and historical discourses are often alluded to cinematically through dominant filmmaking practices, codes of representation built around classical narrative cinema. Peter Wollen in his 1972 essay Godard and Counter-Cinema states that this classical style can be categorized by narrative transitivity, whereby the narrative flows progressively; identification, either with a central character or characters; transparency of cinematic techniques; a single diegesis, that is to say, an individual world in which time and space follow logical, unbroken sequencing; closure and pleasure. Hukkle, in accordance with Marks, utilizes the established language of genre cinema. The film incorporates

10 Minor cinema incorporates diasporic, intercultural, colonized, postcolonial, neo-colo nial filmmakers as well as other marginalized groups/individuals striving to broaden the scope of established historical discourse.

11 Marks, The Skin of the Film, p. 28. 
traditional components from the thriller genre in which "[t]he viewers are motivated by narrative suspense to figure out why the murders occur and how the film will end"12. However, as David Martin-Jones suggests of minority cinema, Hukkle "takes a major cinematic voice and makes a minor use of it, making it stutter or stammer"13.

The process of making minor use of a major cinematic voice in Hukkle is achieved through the de-centering of narrative. The film's central mariticidal narrative is far from explicit and, throughout, narrative elements are shrouded under the surface of the traditional imagery of country life, described by Anikó Imre as "aesthetic distractions" ${ }^{14}$. Indeed, György Kalmár states: "[i]t takes time till one realizes that there is a narrative, or at least there can be a narrative, established among the various pictures of plants, animals, inanimate objects and people"15. Hukkle, while adhering to the logic of cause-and-effect narrative structuring, eschews narrative linearity. The digressive rural imagery utilized throughout the film serves to retard narrative progression and render narrative connectivity indistinct.

Furthermore, scenes of narrative significance blend seamlessly into the juxtaposing rural imagery in such a way that narrative development becomes unclear. The scene in which the midwife (Mrs. József Rácz) picks lilies provides a fitting example. This scene, removed from the narrative, appears to present a very romantic image of the countryside. The midwife sings to herself as she leisurely picks lilies; the sky is blue, birds sing, crickets chirp and bees buzz as the camera slowly roams around the field to reveal a passing stork, which then takes flight. Preceding this scene, we see time-lapsed shots of the lilies growing. Initially, the hastened growth of the lilies appears to provide further evidence in support of the theory that Hukkle presents village life as Edenic, in that the land appears as if to be yielding of itself. However, it is only in light of later scenes that the significance of the lilies is made apparent. In subsequent scenes, the midwife is seen decanting an ominous white liquid into small bottles and, later still, we observe her distributing them among the womenfolk on the production line of a clothing factory. Following this, we see several different women adding the mysterious liquid to

12 Anikó Imre, Identity Games: Globalization and the Transformation of Media Cultures in the New Europe (Cambridge, Massachusetts and London: MIT Press, 2009), p. 217.

13 David Martin-Jones, Deleuze, Cinema and National Identity: Narrative Time in National Contexts (Edinburgh: Edinburgh University Press, 2006), p. 36.

14 Imre, Identity Games, p. 203.

15 György Kalmár, "Body Memories, Body Cinema: The Politics of Multi-Sensual CounterMemory in György Pálfi's Hukkle," Jump Cut: A Review of Contemporary Media, Vol. 55 (2013), 13 May 2014, http://ejumpcut.org/archive/jc55.2013/kalmarHukkle/index.html. 
food, which is then served to their husbands who, shortly thereafter, die. Thus, despite Hukkle's lack of explicit narrative statements, it may be inferred that the poison used to systematically kill off the village's male population has its roots in the lilies picked by the midwife.

The film also de-centers narrative through characterization. Classical narrative cinema traditionally utilizes character motivations as a means of advancing the plot. Hukkle, alternatively, complicates such notions by lacking a central character who we follow in pursuit of their goals. The one character who may perhaps be identified as the film's central protagonist is the hiccupping man who features recurrently throughout the narrative and whose hiccups serve as the motivation for the film's title ${ }^{16}$. However, he is conspicuous in his lack of action and for the film's duration he sits and observes the world as it passes him by ${ }^{17}$. Additionally, Hukkle's more active characters, the women who poison their kin do so without emotion, show neither remorse nor concern of reprisal, their murderous deeds are carried out with the same nonchalance as their daily chores and tasks. Consequently, the audience is denied any real emotional engagement. Estrangement is furthered by the lack of dialogue, which restricts subjectivity and, as such, we learn nothing of the women's motivations.

Thus, while utilizing dominant genre conventions, Hukkle positions itself in opposition to the dominant language of cinematic narration that, as Theodor W. Adorno and Max Horkheimer suggest, "train[s] those exposed to it to identify film directly with reality" 18 . Adorno and Horkheimer argue that classical narrative cinema, cinema based around immersion and character identification, ultimately reduces the spectator to a state of passivity by nullifying individual imagination and spontaneity. Hukkle instead encourages active spectatorship; the film's complex narrative structure necessitates attentive participation on the part of the spectator who is encouraged to piece together its dislocated narrative strands into a cohesive whole ${ }^{19}$. Through the film's de-centered narrative configuration, Pálfi

16 Hukkle is an onomatopoeic word.

17 The man's hiccups serve as a means of connecting the film's divergent narrative strands, localizing them to a centralized focal point.

18 Theodor W. Adorno and Max Horkheimer, "The Culture Industry: Enlightenment as Mass Deception," Dialectic of Enlightenment: Philosophical Fragments, (Stanford, California: Stanford University Press, 2002), p. 100.

19 Pálfi himself declared that "the film is an experimental movie that respects the audience.... The film is a game too, and I think, if somebody likes to play, he or she will like my film too. This is not a weird film for me; it only uses a different storytelling system." Anthony Kaufman, "György Pálfi's "Hukkle," the Hungarian Hiccup Heard 
encourages his audience to attentively scrutinize the film's representation of rural Hungary to reveal the true horrors of the film's mariticidal narrative.

By utilizing a mode of representation that advocates critical spectatorship, Hukkle shares the political motivations of Bertolt Brecht's epic theater. In accordance with the Brechtian alienation effect, a theatrical concept that seeks to heighten its audience's perception of the constructed nature of social reality through the artificiality of the theater, Hukkle seeks to emphasize the devised nature of revisionist historiography within post-communist Hungary. Analogous to Brecht's notion of epic theater, Pálfi employs methods of distanciation via the film's disjointed narrative and refusal of affective character identification to induce a social and political response from its audience. In doing so, Hukkle encourages its audience to question more than just the rose-tinted representation of village life, the film guides the spectator toward wider social and political contemplation.

It is through Hukkle's formal arrangement that the audience is encouraged to question the idyllic representation of the rural that the film establishes from its outset. As György Kalmár rightly observes "[m]edium shots - which follow the heritage of Renaissance portrait-painting, framing the person's upper body, staging the human figure as central focus-point of artistic representation - are conspicuously rare in this film"20. Kalmár suggests that the film's deviation from traditional cinematic language positions Hukkle as a cinematic counter memory and, indeed, this is a valid argument. I would further this claim by suggesting that Hukkle's formal language provides the spectator with a perspective through which to scrutinize the ostensibly Edenic images presented. The film's magnified visual style, predominantly made up of close-up imagery and amplified audio, functions as symbolic device that foregrounds active cinematic engagement on the part of the audience. Through heightened cinematography and audio, Hukkle accentuates the seemingly banal, drawing attention to that which would otherwise go unheeded and in doing so directs the audience to consider the film's more intimate details ${ }^{21}$. The probing, close-up imagery provides a means of looking beyond the surface, a form of observation that transcends the superficially idyllic vision of village life to unveil its true nature.

Indeed, the film opens with a sequence literally taken from a perspective underneath the surface. Before we are introduced to the village, we are presented with an extreme close-up shot of a snake. The image does not focus upon its head but

Around the World," Indiewire (2003), 13 January 2016, http://www.indiewire.com/ article/gyrgy_plfis_hukkle_the_hungarian_hiccup_heard_around_the_world.

20 Kalmár, "Body Memories, Body Cinema."

21 Hukkle was the first Hungarian film to utilize a Dolby Digital Soundtrack. 
instead an indeterminate section of its body. The chiaroscuro lighting suggests that the image is taken below the surface as natural light flickers from above, drawing attention to the texture of the snake's scales. After a few seconds, the snake begins to unfurl, the amplified audio further emphasizing this motion. The image cuts to several similar close-up shots taken from indistinct sections of the snake's body. These shots serve to give priority to smaller details that would be lost through more traditional framing. Only then do we see the snake's head as it emerges from the rocks. It can be argued that the snake, like the serpent whose deception ultimately cast Adam and Eve from the Garden of Eden, serves to disrupt the illusionary Eden that the film will proceed to portray through the representation of the village. However, it is not the snake itself that holds significance but rather the way it is presented. Through the subterranean cinematography utilized in the depiction of the snake, Pálfi creates a visual metaphor in which audiences are encouraged to look beyond the surface of the film's ostensibly paradisiacal vision of village life to reveal the darker realities that these images conceal.

Penetrative perspectives and those taken from positions beneath the surface become a recurring motif throughout the film. It is from a shot in which the camera descends into the water as it follows a piece of bait cast by a fisherman that we are first made aware of the body that lies undetected in the river. Through penetrative motion, the camera breaches the soil to reveal a mole as it tunnels below the earth. We later see the accelerated germination of a lily seed which begins underground and then erupts through the earth to the surface. Yet, perhaps the most conspicuous of these sequences is the scene in which a fisherman returns home with his catch. His wife prepares the fish but only the husband eats. The camera tilts upward from a medium close-up shot of the fisherman's plate and slowly pans around the room, revealing the rest of the family watching the man as he dines. The camera proceeds to tilt downward, reframing the fisherman as he consumes a spoonful of food. During this motion, the shot transforms into an X-ray image of his skull as he chews and swallows. The camera follows the mouthful of swallowed food down his throat to his stomach when the image then transitions to an X-ray photograph on a hospital wall. The repeated use of subterranean and/or penetrative, permeative cinematography reiterates the visual metaphor established at the very beginning of the film, emphasizing the need to look beyond the superficial, surface details that shroud the more disagreeable secrets that the villagers possess. Akin to the political and social philosophy of Brecht's theater, Hukkle's visual metaphor holds wider social implications. By encouraging the audience to analyze the film's Arcadian rural imagery through probing cinematography, Pálfi suggests a need to look beyond the rose-tinted 
renderings of history prevalent in contemporary society in order to engage more openly with the harsher realities of the past.

In a similar fashion, many of the key scenes that implicate the womenfolk in the murder of their spouses are shrouded and obscured by elements of the miseen-scène or other rural imagery that requires the audience to, again, look beyond surface details. For example, we see a man taking his pig to a nearby farm for it to breed. As the pigs copulate, we see the man and another woman watching the animals mate, the man framed in close-up as he drinks a glass of pálinka. The shot cuts to a similar close-up of the woman, her head filling the right side of the frame. The handheld camera conspicuously shifts leftward to a position between the shoulders of both the man and woman and refocuses to capture movement behind a lime green fence. The image cuts to a closer shot that reveals the shadowy figure to be the midwife seen earlier picking lilies. Again, the shot is framed from behind the fence, the shaky, handheld imagery sporadically framed by the unfocused green rails of the fence. Here we see the woman decanting a mysterious chalky liquid into small bottles. What is noteworthy about this sequence is the way in which Pálfi encourages the audience to look beyond the surface detail. Here, we are presented a typical rural scene in which a man takes his pig to stud and the cinematography forces the audience to look beyond it, literally over the shoulders of the man and woman, to reveal vital narrative details that lurk behind the rural imagery, details that pose questions of the film's bucolic representation of rural life.

A further example can be found in the scene in which another elderly resident hosts a dinner for her family. Again, through detailed close-up imagery, the film depicts a traditional scene in which the woman plucks the feathers of a chicken, chops onions and prepares a roux with strudel flour. The scene's emphasis on the rich colors and textures of the food recalls Zoltán Huszárik's Szinbád/Sinbad (1971), a classic of Hungarian cinema and significantly a film about nostalgic reflection. The family enjoy their meal as a bottle of Tokaji wine is passed around the table; it is indeed an image that evokes traditional values centered on the family. The old woman does not join them at the dinner table and instead attends to her husband's meal that must be liquidized. She pours the contents of a plate into the food processor but before transferring the pureed food onto her husband's plate the image cuts to a shot taken away from the dinner table from a position outside of a window. The handheld camera shoots through a net curtain as we watch the woman reach into the cupboard through the yellow sunflower patterns of the curtain. The image cuts to a close-up of the cupboard, a zoomed shot taken from the same position outside of the window. The woman takes out a small bottle wrapped in newspaper, a bottle similar to those decanted by the midwife seen in 
an earlier sequence. She tips a capful of the liquid into the blender and returns to the table emptying the contents of the food processor onto her husband's plate. Again, the film presents a key narrative moment reticently, cloaking the scene behind elements of mise-en-scène that necessitate we look beyond the surface and behind the facade of traditional rural life.

Throughout Hukkle, Pálfi continuously undermines the illusion of Arcadia initially presented by encouraging his audience to look beyond the surface of the bucolic rural imagery through the film's probing and penetrative cinematography. In doing so, Pálfi seeks to challenge the dominant discourse of historical remembrance. By destabilizing the Arcadian representation of rural life, Hukkle seeks to contest prevalent post-communist historical mythologies built around restorative nostalgia, myths that serve as reactionary and therapeutic responses to what Vladimir Tismaneanu describes as "the sentiments of discontinuity, fragmentation, and overall confusion of the post-communist stage"22. Hukkle guides its audience toward the realities that underlie the dominant historical myths through its de-centered mariticidal narrative, suggesting that underneath the heavily idealized rendering of the past lies a more disturbing reality that needs to be addressed and reconciled.

\section{Bibliography}

Adorno, Theodor W. and Max Horkheimer. "The Culture Industry: Enlightenment as Mass Deception.” Dialectic of Enlightenment: Philosophical Fragments. Ed. Gunzelin Schmid Noerr. Trans. Edmund Jephcott, 1944. Stanford, California: Stanford University Press, 2002, pp. 94-136.

Bodó, Béla. “The Poisoning Women of Tiszazug." Journal of Family History, Vol. 27, No. 1, 2002, pp. 40-59.

Boym, Svetlana. The Future of Nostalgia. New York: Basic Books, 2001.

Hockenos, Paul. Free to Hate: The Rise of the Right in Post-Communist Eastern Europe. New York: Routledge, 1993.

Imre, Anikó. Identity Games: Globalization and the Transformation of Media Cultures in the New Europe. Cambridge, Massachusetts and London: MIT Press, 2009.

Kalmár, György. "Body Memories, Body Cinema: The Politics of Multi-Sensual Counter-Memory in György Pálfi's Hukkle." Jump Cut: A Review of Contemporary Media, Vol. 55, 2013. http://ejumpcut.org/archive/jc55.2013/kalmarHuk kle/index.html (13 May 2014).

22 Tismaneanu, Fantasies of Salvation, p. 6. 
Kaufman, Anthony. "György Pálfis "Hukkle," the Hungarian Hiccup Heard Around the World." Indiewire. 26 November 2003. http://www.indiewire.com/ article/gyrgy_plfis_hukkle_the_hungarian_hiccup_heard_around_the_world (13 January 2016).

Kiss, Csilla. "From Liberalism to Conservatism: The Federation of Young Democrats in Post-Communist Hungary." East European Politics and Societies, Vol. 16, No. 3, 2002, pp. 739-763.

Marks, Laura U. The Skin of the Film: Intercultural Cinema, Embodiment, and the Senses. Durham, North Carolina; London, England: Duke University Press, 2000.

Martin-Jones, David. Deleuze, Cinema and National Identity: Narrative Time in National Contexts. Edinburgh: Edinburgh University Press, 2006.

Némedi, Dénes. "Remarks on the Role of Peasants in the Hungarian Ideology." Journal of Popular Culture, Vol. 29, No. 2, 1995, pp. 67-75.

Réthly, Ákos, Ed. In the Shadow of Stalin's Boots: Visitor's Guide to Memento Park. Budapest: Private Planet Books, 2010.

Tismaneanu, Vladimir. Fantasies of Salvation: Democracy, Nationalism and the Myth in Post-Communist Europe. Princeton, New Jersey: Princeton University Press, 1998.

Wollen, Peter. "Godard and Counter Cinema: Vent d'Est." Afterimage, Vol. 4, 1972, pp. 6-17. 


\title{
Chris LaLonde
}

\section{SUNY Oswego \\ 17. "I don't know": Linking past and present, the personal and the nation, and movement in Sterlin Harjo's This May be the Last Time}

\begin{abstract}
A critical conflict for the Native Americans and First Nations people of North America, perhaps the critical conflict, has to do with past wrongs suffered that remain unaddressed. What is more, the trauma born of removal, of the boarding school/residential school era, of the relocation program and Termination Policy in the United States, of nothing less than attempted genocide on both sides of the border between the United States and Canada is exacerbated by the majority societies of the United States and Canada either remaining blind to these inconvenient truths or holding that past events are just that, past, and that natives need to get over what has happened. Native literary, visual, and performing artists counter this way of thinking with words, objects, and images that bring to light stories of loss, of resistance, and of recovery.

For the International Conference in Small Cinemas, I propose to discuss how in the documentary This May be the Last Time (2014) Muscogee Creek-Seminole filmmaker Sterlin Harjo brings together personal history, local history, the history of Removal, World War II, the Vietnam War, and congregational line singing in order to articulate connections between past and present and between song and loss in the name of what Gerald Vizenor terms survivance. Vizenor argues that survivance counters the narrative of tragic and passive victimry with and through stories that articulate an active presence. One should see This May be the Last Time's through line of movement as signaling just such an active presence, even as that movement, as is true of Harjo's other films, is connected to death and at least seeming absence. Although not precisely migration, the stories of movement help to link the personal to something larger - let us call it the historical and the cultural and thus to a critique of the nation, a recognition of connections, and a celebration of adaptability and community.
\end{abstract}

Keywords: Survivance, Removal, Muscogee hymns, Creek history and culture, technologies of communication or communication technologies

This May be the Last Time (2014), Muscogee Creek-Seminole filmmaker Sterlin Harjo's third of four feature-length films and sole documentary to date, opens with a series of aerial shots from an airplane crossing a forested riparian landscape as an off-screen voice recounts arriving at an Alaska village just prior to the funeral 
and interment of a young Athabaskan man. As the voice-over continues, the camera cuts to the speaker, Muscogee elder Jimmy Anderson, recalling how he had joined the native community in mourning their loss and asked those gathered at the spot where the man died if it would be okay for him to sing a hymn that his Oklahoma congregation turns to in times such as this one.

The initial sequence is telling, and not simply because it sounds a pan-tribal note of unity stretching from Oklahoma to Alaska, unity inflected, at least in this instance and in Jimmy's mind, with Christianity; the opening also puts before us what might be termed a problem. That is, how do you take what underpins the story the majority society has long told about indians, ${ }^{1}$ a story that is one of movement leading inexorably to disappearance and death, and reappropriate it in order to tell a life-affirming story of indigenous presence? Harjo's three fiction films work to bury the indian while showing the audience that natives are still here. In Four Sheets to the Wind, for instance, Frankie Smallhill's body is not in the coffin festooned with parodic indian icons created by a well-meaning family friend, his son Cufe having submerged the body in the pond as his father wished, and the closed coffin - containing a watermelon with a smiley face drawn on it as part of the weight added to make the ruse work - reveals that the stereotype is what is to be buried in and with the film and that the joke is on the audience if we were expecting a typical indian film.

What holds for the fiction films holds for the documentary as well, as This May be the Last Time tells the story of his grandfather's absence and of a style of singing found in Creek and Seminole Christian churches in Oklahoma. Rather than avoiding important past conflicts and with them the pain of loss, on the one hand, or what is for some the controversial question of change and its effect on natives today, on the other, Harjo addresses both as This May be the Last Time stitches

1 Those familiar with native/indigenous studies will recognize the lowercase italicized indian as White Earth Anishinaabe Gerald Vizenor's turn of phrase to describe the construction created and perpetuated by that society. Vizenor has for more than fifty years argued that the narratives offered by the dominant society, be it north or south of the 49th Parallel, would have natives be seen, and come to see themselves, as indians, the construction created and perpetuated in order to consign natives to the status of victim in a tragic story. Vizenor will have none of it, would ask us to have none of it, for victim and victimry are passive. Other stories, native stories, articulate an active presence and, in doing so, sound a striking and insistent note of resistance. Thus, to deploy one of Vizenor's key terms, these are native stories of survivance, stories that voice not simply survival but, as the suffix indicating condition and action signals, resistance, continuance, and endurance. Native stories, then, are "successive and natural estates [that are] an active repudiation of dominance, tragedy, and victimry" (Fugitive Poses 15). 
together personal history, local history, the history of the Removal of Southeastern Nations in the nineteenth- and twentieth-century wars, and congregational line singing in order to articulate connections between past and present and between song and loss - all in the name of survivance.

In March 1962, Pete Harjo's car is found wrecked in the Little River just north of Sasakwa, Oklahoma, having gone off the State Highway 56 bridge spanning the stream. There is no body. The search for Harjo runs for days, involving law enforcement, local divers, and Creek and Seminoles from Sasakwa and the surrounding area. The natives set up camp beside the river and from there go day after day looking for any sign of Pete. Born seventeen years after the accident, Sterlin Harjo grew up hearing the story of his grandfather's disappearance and the subsequent search "hundreds of times," and, in his words, "the thing that always stuck out to me about this story was the songs" the people sang as they searched the river and its banks. He recognized those songs, he tells us, because they were the ones he heard and sang in church.

The Muscogee hymns are a response to great, indeed in some ways cataclysmic change. Roughly a third through the film, just after having linked Pete's absence, his missing body, and the untold or missing story of Muscogee hymns and American music, Harjo is careful to sound a cautionary note about change, saying "For most things in Native communities, change isn't necessarily a good thing. It can represent loss. Loss of culture and loss of the way things used to be." However, This May be the Last Time shows us that the hymns are both connected to the past and rooted in native cultural practices and the worldview underpinning them. According to Muscogee poet and musician Joy Harjo, the hymns were influenced by the ceremonial songs of the people, just as the church grounds, pictured as often in the film as are church interiors, were influenced by the ceremonial grounds. Early in the film, Joy Harjo tells us that a song is the spirit of something and that it "appears when somebody needs it." Such was the case during Removal. Nelson Harjo imagines what the forced march was like, the People allowed to stop only when the soldiers' horses needed rest, sees in his imagination a native woman taken into the bushes by the soldiers, raped as her husband and the rest of the captives within earshot hear the rutting men, hear first her screams and then her sobs. From that, he says, song is born. Another interviewee says "our people pulled

2 Near the film's end, Jimmy Anderson will make an explicit return to this issue when he speaks of needing to respond to young natives who ask him about Christianity's role in the forced removal of their people. Jimmy can only resort to God's love and forgiveness with his reply, in effect not answering the crucial question. Harjos film provides the answer. 
a fast one on the missionaries" in particular, and the whites in general, when they adopted Christianity, because the "hymns are all about survival."

The Muscogee hymns are sung a cappella in what is known as congregational line singing. This lining-out style is found in the Highlands of Scotland, in white churches in Appalachia Kentucky, in African-American churches in Alabama, and in Muscogee Creek and Seminole churches in southeastern Oklahoma. In short, it is a striking example of transmission, adaptation, and hybridity. This May be the Last Time would have the audience learn about and understand what musicologist and Muscogee Creek church member Hugh Foley calls "a whole rich story of American music that had never been told." Joy Harjo links the heretofore missing story of the Muscogee hymns with the missing story of native people: "indigenous people have been written out of the story of America and the story of culture. It's like its been sitting there all along. It's right there in the face of American music and yet that story has been disappeared and left out."

"Sitting" is a curious and I think playful word here, for prior to Removal, Creek life featured movement as the loose confederacy of the nation necessitated that town leaders travel to meet as political need arose. Moreover, trails linking the eighty to ninety towns beside streams that make up the river systems of North Alabama and Georgia facilitated trade, enabled Creek to visit fellow clan members in distant towns, and allowed both individual Creek and whole families to move on paths through the oak-pine forest and along and across streams of the Piedmont region in search of wood, water, and game (Hudson, 2010: 12-14). In short, movement was a central feature of Creek life, personally, socially, economically, and spiritually. It is a central feature of Harjo's documentary as well. Indeed, the initial sequence of This May be the Last Time accentuates movement and perspective with its series of three aerial shots followed by a high long shot of what we take to be a river in Alaska. That river serves to link the opening with a river in Oklahoma and the story that follows.

In the film's lengthy opening, running some seven minutes and forty seconds from first image to the title shot, Harjo, narrating his film, articulates a specific native view on the Mississippi River - one that resonates with how the film would have us see the Little River in Oklahoma. Over a slow pan of the Mississippi, Harjo says "Thousands died along the way to Indian Territory. Countless people drowned in the Mississippi River." For the People, the Mississippi is not, then, the route to freedom that Twain offers readers some fifty years later in The Adventures of Huckleberry Finn, for, as Harjo says, "In our songs the people refer to the Mississippi River as the river of death." 
Immediately after the slow panning shot showing us the Mississippi as the narrative tells us how that river figures in Muscogee stories and song, Harjo's camera offers a shot of Natives on parade in dance regalia announcing their presence and celebrating their identity as the voice-over quietly, even matter-of-factly, proclaims "Through it all the people survived. We rebuilt our tribe in Oklahoma. Our ceremonial way of life came with us. Our traditional religion and songs. Today they are thriving." Shot accentuates narration, and vice-versa, both by the dance regalia and the multiple generations it contains: adults, children, and elders. The death march, in short, is visually and aurally countered, supplemented by an objective movement shot celebrating survivance.

With a four-second shot without any narration of a snake coiled on a gravely shore at very nearly the midpoint of the film, This May be the Last Time succinctly articulates its grounding in traditional Creek and Seminole culture and worldview critical to the People's survival past and present. Their stories tell of the tie-snake lurking in the waters they followed and crossed. If taboos were broken during a journey, the tie-snake could take one down to a watery death. Like the waters themselves, mind you, the tie-snake was not inherently malevolent, and there are stories where it comes to the aid of the people. A creature associated with the chaotic below world, the tie-snake is balanced by the Thunderers of the above world. In short, the shot of the snake asks us to be cognizant of another way of seeing and being in and with the world. In Donald Justice's words, "Southeastern tribal values descended from Mississippianism privilege complementarity over opposition" (p. 222) and humans in the middle world help to keep the balance both by recognizing and prizing complementarity and by taking care not to transgress taboos.

The shot resonates historically as well as culturally. The Muscogee Creek and other southeastern nations resisted the Dawes Act of 1867, desiring, rather, to continue to think of land and possession as they had before contact and Removal. The Curtis Act of 1898 abolished the court systems of the Creek, Choctaw, Cherokee, and Chickasaw and, critically, forced allotment onto the Creeks over their wishes and the continued refusal of many. For at least the first decade of the twentieth century, a group of Muscogee led by Crazy Snake resisted. The Snake Faction, as they were known, reinstituted traditional Muscogee government - an act of defiance against both the Federal Government and the various agreements and concessions made by tribal leaders at the turn of the century. Following an armed standoff in 1901, leaders of the Snake government were captured and pled guilty to seditious conspiracy. Although admonished to cease organizing by the Federal judge who sends them home, the Snakes persisted to meet in traditional town councils. Eight years later, another armed standoff weakened the Snake Faction. 
Immediately after the shot of the coiled snake, Harjo's camera offers the audience a shot of a bridge over the Little. Here and throughout the film, shots of bridges are used to accentuate movement and to make connections both within the individual strands of the film and between them. Indeed, this begins five minutes into the film when, after Jimmy Anderson concludes his story of singing in Alaska, a jump cut to a black screen then transitions to a time-lapse image of a bridge as it emerges from darkness into the light of day followed by a shot of drops making radiating circles on the river's surface ${ }^{3}$. Together, these early shots visually situate the documentary in relation to the story that it will show us, obviously, as sight is linked to site, while the time-lapse photography effectively, and again obviously, shows us that This May Be the Last Time is to be about time while accentuating the ability of the moving image to capture the passage of time and manipulate it in the service of story. Later, we see a shot of another bridge spanning a river as Harjo's narrative recounts the death march. We are offered day shots of a bridge seen from a moving vehicle, night shots through the windshield as it crosses a bridge over the Little. Two white men who were boys at the time of Pete Harjo's disappearance stand beside the river with a bridge in the immediate background as they recall the search for the body. We see shots of superstructures helping to hold up bridge decks.

When Harjo offers us with no narration an earlier shot of traffic on a road beneath a bridge as the transition between the narrative's articulation of the origins of the Muscogee hymns and where he grew up in Oklahoma on the border between the Muscogee Creek nation and the Seminole nation, the seemingly throwaway image makes clear what the Snakes fought for and what helps to ground the People. "Native land" is written on a pillar of the overpass. Their land supports the People and helps them to connect past and present, to join Western practices such as Christianity and church-going to Muscogee Creek and Seminole ways of knowing and being in the world. The church grounds are modeled on the ceremonial grounds after all, we are told. The film subtly emphasizes the centrality of land to the people and as a ground for their hymns and the appropriation of Christianity when relatively early on after Nelson Harjo tells us that an old Pastor told his congregation that with the hymns "we were waking up god," we see landscape shots at sunrise and dusk with English subtitles as a Muscogee hymn is being sung. Much later, the connection between land and spirituality,

3 Those radiating circles mark a connection between This May be the Last Time and both Four Sheets to the Wind and traditional Muscogee and Seminole worldviews (see below the passage on concentric circles and cyclical thinking in this chapter). 
and being, is made explicit by pastor Houston Tiger when he says that he turns first not to scripture as he contemplates his sermon, but to the land: "I get my knowledge out in the wilderness. I fast and pray." Only then is he ready to turn to the Bible. This, then, is why This May be the Last Time keeps the land before its audience from first to last.

To have the land before us, to have it on our mind, is to redirect our attention not to the heavens (recall the film's opening aerial sequence), not to the hereafter, but to the here and now and how it came to be as it is. For the Muscogee Creek and Seminoles, for the other nations of the Southeast United States, for so many other native nations, land and loss are linked, of course, and thus it is little wonder that This May be the Last Time has America on its mind throughout its course. Indeed, the film gives us an image of the American flag immediately after the first credits end. Shot directly below with the colors barely unfurled, the image initially gives the impression that the flag hangs upside down. Thus, we are asked to recognize an image of a nation in distress. An hour into the film, as Wotko speaks of his tour of duty in Vietnam and the bad things he and his fellow soldiers did there, we get a lap-dissolve sequence from combat to the American flag and back again. Wotko's story then makes clear why the nation is in distress as it links Vietnam and the history of his people. He talks of feeling sorry for the civilian residents of a village in which Viet Cong were suspected of being: "I just looked at those villages and they were handmade by all the villagers, just like back in the old days in Georgia and Alabama when our people were being moved and them villages being burned." What may seem the imprecision of Wotko's phrasing is anything but, as it conflates villages in twentieth-century Vietnam with native villages in nineteenth-century America. In short, the colonialist and imperialist drive, the desire to possess and control, is damning - to both the native and to the Settler Nation.

Harjo entitles his documentary with a portion of the title of his grandma Johnnie Mae's favorite hymn, "Espoketis Omes Kerreskos," or "This May be the Last Time, We Don't Know." Song and death are again explicitly linked, for Harjo says that they sang the hymn to her as she lay dying, Johnnie Mae tapping along with the rhythm of the song even though she "wasn't really conscious." Harjo recognized even as a boy that the song's rhythm was different from that of the other Muscogee hymns he knew, doubtless, he later learns, because of its roots in African-American slave spirituals. When the hymn is first sung in Muscogee is not recorded, Harjo tells us, but it has not changed since that time in the nineteenth century. Then and now, "Espoketis Omes Kerreskos" stresses group cohesion, one might even say community: "This may be the last time, we don't know" (emphasis 
added). Fitting hymn, then, this, as it is sung to his grandmother and, as the film is careful to tell and show us throughout its course, as the people gather together on the banks of the Little River day after day to search for Pete's body. It is only after a traditional healer and seer comes that the body is found.

Very near to the film's end, Harjo says "Anyone you talk to about these songs will say the same thing. They are dying out. There's going to be a day when they're gone." His film is a counter to that somber claim, however, as he continues, "but these songs echo throughout our community. They echo throughout our stories. And as long as we keep telling them, they will always be here. In death, in worship, in sadness, and in joy, encouraging us." Harjo's body of work to date subtly shows us that one location for living elements of Muscogee and Seminole material and symbolic cultural practices, another "here" if you will, are the products of recording and playback technologies, information and communication technologies (ICTs) more generally; photographs; and indeed film itself. His films highlight and call our attention to representation and technologies of communication. For example, a phonograph appears early on in Four Sheets to the Wind, a record continuing to turn after the stylus has run through the final groove; with that image, we get a striking reinforcement of the concentric circles we see radiating from Cufe's body as he stands in the pond after submerging his father's body, the circles, a visual reference to Muscogee and Seminole understanding of the world and of the cyclical thinking born of that understanding. ${ }^{4}$ From this point of view, the shot of the coiled snake in This May be the Last Time does not so much reinforce the image of something about to strike as it reinforces, fittingly, an image of concentricity.

The links between visual representations, still or moving; communication technologies; and culture are readily apparent in the opening sequence of Barking Water. The extreme close-up of Irene's eyes followed by a shot revealing that she is looking at photographs signals that we, like her, need to see and, in particular, need to pay attention to representations. As her dying ex-partner Frankie is wheelchaired out of his room and the hospital by an orderly helping Irene to free him, we get a shot framed to draw our eye to a hanging display of traditional southeastern native dress. This early signifier of what scholars label the Mississippian

4 The phonograph can be read as an afterimage, or better still a supplement, of the most famous phonograph in film featuring indians: Nanook of the North (1922). While in Flaherty's film the phonograph remains a mystery to Nanook, even as it reveals to its twentieth-century audience Nanook's innocence/ignorance concerning technology, in Harjo's film the phonograph signals both an awareness of technology and the role it can play in communicating contemporary natives and their culture(s), not the vanishing native of Nanook. 
Ideological Interaction Sphere (MIIS), that is to say "the cosmosocial matrix through which most of the contemporary tribal nations of Oklahoma are (and other Eastern Woodlands people) are linked," is telling, surely, and not simply to signify the shared worldview of the Muscogee Creek and Seminole within which the story is rooted. The shot also frames a question: how does one take culture and cultural practices from a fixed and frozen display so that they will resonate, so that they and the People may live. The sequence offers us an answer with a shot the camera stays with after the orderly rolls the wheelchair down the short passage and into Frankie's room. We see a young woman first standing, then pacing across the hall, and finally sitting down on floor with her back against the wall. She does not speak. She texts.

Here, then, just as early in Four Sheets to the Wind with the phonograph and later with photography and throughout This May be the Last Time via photographs, cassette recordings, and radio, Harjo highlights representation and the potential and power of technologies of communication. Indeed, This May be the Last Time makes clear it is not until Hugh Foley plays a recording he made of hymns he has been singing with other church members that he hears echoes of African-American spirituals and subsequently sets off on a journey through American music to learn more about the hymns and their origins. A National Public Radio (NPR) broadcast on congregational line singing with no mention of the Creek tradition is heard by a Muscogee woman: she contacts Foley, Foley sends a query about the program to Yale scholar Willie Ruff, Ruff calls Foley, and ultimately a second conference is held at Yale in order to include the previously "unknown" part of this singing tradition in America - what at the second conference Ruff terms "these songs of survival." In short, if recording and playback technologies can reveal what has heretofore been hidden, often in plain sight and sound, then the emphasis on them in the films tacitly reveal that for Sterlin Harjo the moving image will be the vehicle to animate culture and tradition while offering them to the audience.

Contra the narrative of death and dying offered by the dominant society, then, think the vanishing indian, think "the only good indian ...," think the "End of the Trail," Harjo gives his audience stories of death and dying as a part of the effort to bury the indian while showing them that natives, in this place the Muscogee and the Seminole people, are still here. We see and hear the hymns being sung, we see and hear young children speaking Muscogee, we are privy to Wotko telling us that he talks to his ancestors as he cares for the cemetery that is part of his

5 Donald Justice, "Notes Toward a Theory of Anomaly," GLQ, Vol. 16, No. 1-2 (2010), p. 217. 
church grounds, and that he knows that they are listening. Like them, we need to listen as the "amen" following the prayer and song at the film's end is immediately followed by mvto, a giving thanks in Muscogee, and then, after a black screen, a joke that accentuates once again recording and playback technologies: Wotko says, "we'll be signing them CDs next month" as the women who have been singing with him laugh. No laughing matter of course, this, as the pain of all the erasures, partial and total, of all the efforts of the majority society to do away with natives, is countered by the work done by Harjo and so many other Native visual, literary, and performing artists.

This May be the Last Time links the discovery of Pete Harjo's body and the discovery of the important position the Muscogee hymns have in the history of American music. Early on, Harjo tells us that the hymns are the same songs the "ancestors sang on the Trail of Tears." He has "wondered where they [the songs] came from," especially given that "they seem always to have been here." This May be the Last Time is, however, not so much about a search for origins as about the end of something: the end of the absence of Pete Harjo's body, of the absence of the Muscogee hymns in the history of American music, of the stereotypical figure of the indian trapped in and by the past. The People survive, they adapt, while remaining rooted in land and worldview. Wotko says he felt sorry for the Vietnamese "caught in the middle of it all," but Harjo's film reveals the middle ground need not be a trap. Just as a bridge serves as a middle ground between and connecting two points, traveling across it cognizant of the need for balance, for reciprocity, and respect for the land - fundamental elements of Creek worldview might well save us all. I don't know.

\section{Bibliography}

Deer, Sarah and Cecilia Knapp. "Muscogee Constitutional Jurisprudence: Vhakv Em Pvtakv" [The Carpet Under the Law]. Tulsa Law Review, Vol. 49, No.1, 2013, pp. 125-181.

Hudson, Angela. Creek Paths and Federal Roads: Indians, Settles, and the Making of the American South. Raleigh, NC: University of North Carolina Press, 2010.

Hurt, Douglas A. "Defining American Homelands: A Creek Nation Example, 1828-1907." Journal of Cultural Geography, Vol. 21, No. 1, 2004, pp. 19-43.

Justice, Donald. "Notes Toward a Theory of Anomaly." GLQ, Vol. 16, No. 1-2, 2010, pp. 207-242.

Vizenor, Gerald. Fugitive Poses. Lincoln, Neb.: University of Nebraska Press, 2000. 


\author{
Ilona Copik \\ University of Silesia
}

\title{
18. Post-industrial landscape in the "Silesian cinema": Between the aesthetic and cultural experience
}

\begin{abstract}
An issue discussed in this chapter concerns the movie landscape in terms of its two chosen functions: aesthetic and anthropological ones. The first function originates from the aesthetic tradition and results from the fact of objectification of the picture (image) as a subject of cognition and contemplation, entangled in the sight codes. It assumes stability and distance as a receptive experience. The second one - reading of a landscape according to the anthropological key - is based on the cultural experience that includes activities such as residing (in a place/territory), participation and engagement. It draws attention not to the view of plane itself, but rather to the space depth that can be associated with the issues of geographical environment, cultural representation, topography, and symbolism of a place and locality. In the reflection on this research, the main issue is not treating those functions as an opposition, but rather using the category of landscape to reveal the cultural practices in terms of complex network of relations between subject/environment/ agency, which characterise today's processes of mediation. The subjects of the analysis are the chosen contemporary feature films representing a certain phenomenon of Polish cinematography - "Silesian cinema." The main purpose of this research is an attempt to find answers to the following questions: how do the pictures produced by "small cinema" express the locality? To what extent do they preserve/overcome the visual conventions and cultural stereotypes? To what extent it is possible to capture in a movie the complex problems resulting from the dynamics of sociocultural transformation of a region - especially contradictory visions of relation to modernity/postmodernity, creation of new economical divisions and tensions between global/local?
\end{abstract}

Keywords: Post-industrial landscape, industrial ruins, regional cinema, cultural medium, aesthetic and cultural experience

Traditional "Silesian cinema", namely cinema of the 70 s and the 80 s, which is mostly associated by Polish audience with the names of film directors such as Kazimierz Kutz, Janusz Kidawa, Jan Kidawa-Błoński, Stanisław Jędryka, Zbigniew Chmielewski, regularly presented a manipulative portrayal of industrial landscape, in which a horizon is filled with industrial plants, foundries' chimneys and hoisting shafts as well as workers' settlements harmoniously adjoining them. Their spatial arrangement implies a specific type of social relations, recognised 
as characteristic one for the Upper Silesia culture. Films such as Salt of the Black Earth (1969), Pearl in the Crown (1971), The Beads of One Rosary (1979) directed by K. Kutz, The Sinful Life of Franciszek Bula (1980), Pretenders from Yesterday's Street (1986) directed by J. Kidawa, Closer and Closer (1982-1986) directed by Z. Chmielewski additionally developed a specific way of creating the connection between landscape and regional identity, in which an implementation of subculture is clearly visible. Such a subculture is formed by the occupational group of miners as a result of which the regional culture of Silesia is presented in those films visually as mostly associated with red little houses, gardens with dovecotes, and black slagheaps, and is mentally connected with rites and mining ethos - strengthened and founded in the nineteenth- and twentieth-century agrarian-industrial culture.

Films, which can be classified as belonging to the newest "Silesian cinema" - I think of pictures created in the course of the last two decades - are characterised by a different attitude to regional space, it is mainly a discourse taken up with stereotypically strengthened image of Silesian landscape that attracts the attention of spectators. Even if cinema evokes traditional iconography, it is usually done with the use of hyperbole strategy, sometimes satire, but most of all with the use of nostalgia, of which the foundation is the awareness of moving away from the former world. The landscape in the film clearly captures the transformation of physical landscape and thorough metamorphosis of local space. The audience can notice not only the presence of industrial structures still in operation and post-industrial waste, relics of the progressing processes of restructuring of heavy industry, but also the spread of the light construction industry - the effect of taking into account of urban elements in urban-industrial area of contemporary Upper Silesia. Those elements are characteristic for contemporary metropolitan cultures and are the result of opening for that type of economy, which is called soft industry ${ }^{1}$ by British researcher Tim Edensor. The landscape that became more dynamic in postmodern times is provoking simultaneously questions concerning new meaning of locality in the times of intensified civilisational transformations.

The visible sign of the intensity of contemporary economic and political transformations of the region, which entails a change of local culture, is using the post-industrial landscape by film directors. This type of landscape appears to be particularly interesting from the cultural point of view, because it concentrates on the most crucial problems of contemporary places and areas along with their

1 Tim Edensor, Industrial Ruins. Spaces, Aesthetics and Materiality (Oxford, New York: Berg, 2005), p. 6. 
chronic instability, transitoriness, hybridity as if through a lens. Thanks to that, this landscape can be also considered to be extremely strongly stimulating reflection on the condition of contemporary world and man's place in it. This particular potential of post-industrial relics was probably identified and dealt with most comprehensively and thoroughly by Tim Edensor. According to him: "hidden in ruins are forgotten forms of collectivity and solidarity, lost skills, ways of behaving and feeling, traces of arcane language, and neglected historical and contemporary forms of social enterprise." In the researcher's opinion, the post-industrial landscape has ontological and epistemological meaning. As the symbol of instability, transgression and blurring of borders, the landscape gives also unique possibilities for critical approach, including deconstruction of signs of ideology and authority through initiation of mode of looking in the space where conflicts and forces clash.

The post-industrial landscape is one of the favourite landscapes chosen by contemporary cinema, which is using it eagerly for aesthetic purposes, mainly as the setting in films belonging to the genre cinema. In this case industrial ruins are mostly treated in an abstract way and out of context, being simply a place of action emphasising terror and incredibility of a plot of given thriller or a horror film so that the camera's eye captures the landscape in a distanced and escapist way. The subject of my interest is the post-industrial landscape, which evokes cultural connotations apart from aesthetic ones and at the same time reveals the anthropological potential. It is connected with the fact that artists have overcome a distanced approach and have become engaged emotionally, and involved in some form of immersion in the observed space in order to identify and show nagging problems. In this case, the post-industrial landscape becomes not only a metonymy of the world fate but also a universal symbol of global change connected with the replacement of production model of goods with the paradigm based on consumption and economy of sign, which in the language of social theory was formulated as "post-industrial society,"3 but one of the most important symptoms of transformation at the local level, an identifier of the change of cultural specificity, which affected by processes of neglecting, abandoning, marginalisation of industrial heritage as well as being under the influence of the actions aiming at repeated retrieval, restoration and rejuvenation undergoes numerous transformations.

2 Edensor, Industrial Ruins, pp. 166-167.

3 See Daniel Bell, The Coming of a Post-Industrial Society (New York: Basic Books, 1974); Jean Baudrillard, Toward a Political Economy of the Sign (St. Louis: Telos Press, 1981). 


\section{(In)discreet charm of ruins}

Ruins are a kind of magnetic temptation, which best contribute to exciting the imagination just as a secret garden does. This is more or less the thesis that begins the book about post-industrial ruins by Tim Edensor. Disassembly of industrial buildings and decommissioning of the machinery from the technological usage make their semantics blurred and evolving. The author writes: "Since the original uses of ruined buildings has passed, there are limitless possibilities for encounters with the weird." The researcher tries to convince us that strangeness and the air of mystery of ruins are on the one hand sources of their charm and photogenic nature, and on the other hand, they stimulate a reflection of transcendental and transgressive nature, in which the review perspective and the direction of interpretation become emancipated and liberated from usual limitations. Elżbieta Dutka has similar observations - not only does the presence in the landscape of industrial structures, but also their relics make an impression of a "photogenic" space, at the same time they stimulate the reflection of universal nature, concerning the core meaning of existence, transitoriness of life and inevitability of death that result in the melancholy that marks the industrial as well as post-industrial landscape. ${ }^{5}$ Additionally, the post-industrial ruins reproduce the Vanitas Motif, clearly illustrating that everything in this world falls apart, passes and decays, and that reality is fragile and simultaneously difficult to understand in categories of logical whole, doomed to incomplete and fragmentary cognition.

According to Edensor, this trend of thinking about ruins as a place that is characterised by specific visual beauty is an indication of a succession of romantic aesthetics. The attractiveness of ruins was in this way connected with their origins (preferably medieval), sufficient condition (they must have been relatively well preserved), as well as adequate setting: colour of sky, topography of a land, type of climate and weather conditions. Thus, the conditions stated above were considered to be essential to find a landscape as worthy to contemplate it and evaluate according to traditional aesthetic categories: picturesqueness and loftiness. Ruins understood in this way were a part of an abstract space, out of environmental and corporal context, viewed by a subject distanced from an object of interest. In a more general sense, the issue of distance is a crucial characteristic of aesthetic experience, mentioned by Małgorzata Nitka, who refers to Edmund Burke: things (dangerous or scary) can be a source of pleasure; however, the

4 Edensor, Industrial Ruins, p. 4.

5 Elżbieta Dutka, "Melancholijne pejzaże Śląska" [Melancholic landscapes of Silesia], Białystok Literature Studies, Vol. 3 (2012), pp. 79-96. 
necessary condition for such kind of feeling is scrutinizing them from "a certain distance." ${ }^{\prime}$ The aesthetisation of post-industrial spaces seems to be in this context quite an obvious experiment. Densification of area created by accumulation of industrial infrastructure itself causes the landscape to appear to be exceptional. Its destruction dramatically strengthens this effect. The frameworks of factories, piles of debris, and remains stripped of context and deprived of their function meet demand to make an impression of being alien and detached, creating at the same time a universal space, which can be an intriguing field to all artistic activities. As a synthesis of transformations and transgressions, it turns out to be the adequate setting to play a variety of performances - from ancient tragedy to futuristic drama, especially it is considered to be an attractive film open-air used eagerly by action films or science fiction. Moreover, its characteristic is the surprising photogenic factor, as Susan Sontag aptly puts it: "Bleak factory buildings and billboard-cluttered avenues look as beautiful, through the camera's eye, as churches and pastoral landscapes."

The examples of fascination with industrial and post-industrial landscape can be noted also in films belonging to "Silesian cinema"; however, clearly in this very case, it is difficult to separate aesthetic experience from anthropological one. Silesian cinema as small cinema - the regional cinema is most of all a kind of embodied cultural practice, of which distinctive features are geographical, historical and social relations with a place determined by awareness of regional identity, engaging senses and emotions. Thus aesthetic experience is considered to be insufficient for one more reason mentioned by Edensor: "romantic themes are wholly unsuitable for accounting for the industrial ruins," ${ }^{\text {because it is a }}$ space of problematic nature, in which a complicated history and "varied forms of dense sociality occur." This is true in case of Silesian landscape, of which its photogenic nature almost each time evokes specific real problems. Therefore, if there is marked aesthetisation of landscape in Silesian cinema, it usually goes hand in hand with some form of penetration of a subject that looks into observed space, its intellectual or emotional engagement in the specificity of a place, its response to permeating the landscape economic, political and social issues.

6 Małgorzata Nitka, "Pokłady wyobraźni: poetyka przestrzeni industrialnej” [Layers of imagination: Poetics of industrial space], in: Przestrzeń w kulturze i literaturze [Space in Culture and Literature], ed. Ewa Borkowska (Katowice: Wydawnictwo Uniwersytetu Śląskiego, 2006), pp. 47-48.

7 Susan Sontag, On Photography (New York: Rosetta Books, 2005), p. 61.

8 Edensor, Industrial Ruins, p. 11.

9 Edensor, Industrial Ruins, p. 9. 


\section{Post-industrial landscape and its aesthetic function}

There are plenty of examples of exercising the aesthetic function of the landscape in the newest "Silesian cinema." Simultaneously they demonstrate a kind of intermediation of view on the locality, because the film frames often refer to previous film images that have already gained fixed cultural significance, but also they refer to poetics of literary images or paintings of Silesian intuitive artists (e.g. "Rudzka Group" or "Janowska Group"). The works of art of the latter ones are called in some studies as follows: "regional art," "Silesian art," namely "the art created in Silesia and referring to Silesia." ${ }^{10}$ It is a true regional phenomenon and its essential pillars are mining environments and activity of artistic groups created near hard-coal mines. ${ }^{11}$ On canvas of the painters of the naive, landscape consists of brick houses, green areas of adjoining gardens and black of nearby slagheaps, and is invariably shrouded in a glow of smoke floating in the air from factory chimneys. The themes discussed in this chapter along with the trend of capturing of the local folklore with the use of expressive colouring contribute to a particular type of depiction.

The film titled Public Outrage directed by Maciej Prykowski (2009) clearly relates to this poetics. Through artistic means used in the film plot, it was possible to create a fairy-tale, romantic local atmosphere. The video camera shows picturesque workers' housing estate called Fytel situated among green areas and fields using distant locations. Following the view, the camera's eye displays a subtle charm of a place providing a panorama on the surroundings visible from the tower once a large blast furnace (belonging to "Batory" Foundry in Chorzów), today's vantage point. On the screen, we can see former industrial areas, which gradually have started to grow over with weeds, transforming the terrain into a wild garden, drowning in fog the (post)industrial settlement, peripheral railway station, to which no trains run any more. Photographs taken by Paweł Dyllus emphasise a monumental loftiness of architecture of former foundry's buildings; they capture post-industrial emptiness, which is undoubtedly a counterpoint for a housing estate vibrant with workers' life. However, it is only the aesthetic experience, on which the expression of space ends in that movie; instead of cultural experience,

10 Marian Pokropek, "Śląska plastyka nieprofesjonalna - wyjątkowa kolekcja” [Silesian unprofessional artistic creativity - Unique collection], in: Twórcy intuicyjni z kolekcji Barwy Śląska [Intuitive Artists from the Collection Colours of Silesia], ed. Stanisław G. Trefoń (Ruda Śląska: Stowarzyszenie "Barwy Sląska," 2015), p. 15.

11 See Maria Fiderkiewicz, Ślascy pariasi pędzla i dtuta [Silesian Pariahs of Brush and Chisel] (Katowice: Muzeum Śląskie, 1994). 
there are elements of convention typical for comedy genre. Starting from the way of building narration and ending at drawing of a character, in the movie comes to the forefront as stated Jan F. Lewandowski: "all clownery with the use of not only the setting, but also customs and traditions and even a silesian dialect," ${ }^{12}$ making it one more example of a spontaneous film comedy full of ribald gags.

The next example of the landscape's aesthetisation in the "Silesian cinema" can be seen in a movie titled Hyena directed by Grzegorz Lewandowski (2006), also fitting a post-industrial genre convention - in this case in the form of a horror film. The poetics of space used in that movie is largely referring to the form of contemplation of industrial ruins, which was defined by Tim Edensor as "a sort of modern gothic"13 - product of "post-industrial nostalgia,"14 focusing on "dark urban nightscapes, abandoned parking lots, factories, warehouses, and other remnants of post-industrial culture."15 The ruins are in this case a foretaste to the expected complete degeneration, a kind of tourist attraction, which makes the subject of the description and aesthetic experience not only the processes of decay, decomposition, darkness, but also a communion with the unspoken, marginalised, repressed. The city is perceived as an area of catastrophe, more connected with - the collapse of modernistic structures of the world, undermining of the progression myth, vision of future extermination of civilization resulting in decadence and signs of macabre that contribute to "the topography of gloomy decay." ${ }^{16}$ Significant is the fact that in the movie Hyena the Upper Silesia is not really presented on the screen, neither its name, nor the scope of its topography. The setting, consisting of the left mining premises and industrial facilities along with its surrounding wildlife hideaways, marshes, and tangled paths, is not depicting the region or any other particular city. It is rather abstracted from the geographical context, a post-industrial settlement situated in an undefined space. Spectators may have an impression that the landscape is used here only as a purely aesthetic phenomenon (what is emphasised in the movie by sophisticated architectural layouts entangled by a play of light) and as an element of creating a mood of horror and incredibility.

12 Jan F. Lewandowski, Silesian Cinema (Katowice: Wydawnictwo “Śląsk," 2012), p. 138.

13 Edensor, Industrial Ruins, p. 13.

14 See Edensor, Industrial Ruins, p. 13.

15 See Edensor, Industrial Ruins, p. 13.

16 See Edensor, Industrial Ruins, p. 14. 


\section{Ruins as "a liminal moment"}

Although in the above-mentioned films the aesthetic experience clearly dominates and the setting seems to serve as a necessary background for film plots, it cannot be deemed that the post-industrial landscape is here a completely neutral location. On the contrary, its presence is significant, felt subconsciously to some extent; it symbolises harm, loss and unbalanced social relations. For example, Hyena directed by Grzegorz Lewandowski apart from conventional (aesthetic) connotations makes us think about a space in geographical-temporal categories, which gives rise to nostalgic associations, and thus we realise that a space of contemporary horror film - empty, inhuman and ominous - is a former place of active large workplace with thriving industrial infrastructure and social welfare facilities, vibrant with life and in full swing. In this sense, a ruin reminds us about the crisis that has recently occurred, a dual structure of a place has seen a daylight, a place in which there is a border between the former and the contemporary, which allows us to uncover the hidden layers of memory that show a picture entirely different from the present view. Similar suggestions can also be found in a film titled "Public Outrage," in film frames presenting frameworks of former foundry that make a spectator aware of a whole dimension of economic transformation that has been done.

According to Edensor, the presence of industrial ruins in the landscape is a sign of "a liminal moment," in which a particular place has found its location. That point of time symbolises a state of suspension stretching from abandonment of an area to its falling into total destruction or a discovery of a possibility of redevelopment of an area. In a particular moment, it is considered as a kind of unrealistic terra nullius - no man's land devoid of any distinctive aim of existence. As a post-industrial landscape, it embodies pivotal transitional state between "old" and "new" order, being a "blank area," ${ }^{17}$ which is created after definitive depletion of (natural) resources, at the time, when they have not yet been replaced by new ones. For that reason, it evokes depressive connotations and extreme reactions as a space of shock, loss and "a neglected land." 18

This essential state "in transition," characterised by exceptional emotional tension, has in Silesia its dynamics visible in the ways of using the landscape, both in film and in photography. Transition from "industrial" to "post-industrial" takes place along with political transformation and gets visible in the landscape from the beginning of the 90s. Then "a liminal moment" becomes a discourse about

17 Edensor, Industrial Ruins, p. 8.

18 Edensor, Industrial Ruins, p. 9. 
ecological destruction that results in accumulation in regional iconography of pictures referring to "black Silesia" stereotype - a land devastated by heavy industry, ruined by expansive human activities. ${ }^{19}$ Poetics of an image (and rhetoric of narration) from that period is based on a conviction that long-term, irrational usage of natural resources contributed to a complete destruction of the ecosystem in the Upper Silesia - area - which can no longer be the environment suitable for life of a human being, posing a real danger for today's and future generations. The destruction of industrial landscape at the verge of modern times is associated with disease and death, of which visible signs are degraded soil, civilisation diseases and genetic mutations. Documentaries made on the order of the Ministry of Environmental Protection, Natural Resources and Forestry such as My Region Silesia directed by Henryk Urbanek, Krzysztof Zygalski (1991) or The Fruits of the Black Soil directed by Mirosław Dembiński (1992) - like early photographies made by Michał Cała belonging to collection titled Silesia and Galicia (2013) - show this conflict between nature/culture, humanity/industry, tradition/progress captured in the landscape, in which an apocalyptic vision of destruction - complete devastation of landscape and living environment - ultimately wins.

In the course of ongoing processes of restructuring of heavy industry and closing of consecutive factories and plants, with the result that the most tedious effects of recent exploitation and contamination of environment are becoming less significant, the discourse of "black Silesia" is gradually losing importance. It is obscured by another shock narration adequate for "a liminal moment" - a story about a vanishing landscape. The consequence of political-economic transformation as well as rapid privatisation of state sector and seeking for new sources of profit is waste production, the element of the existing industrial resources treated now as worthless debris. Consecutive buildings, blast furnaces, steelworks, chimneys, hoisting shafts, industrial machines are abandoned or demolished and even the workplace workers' housing estates are subjected to similar practices. Andrzej Stasiuk reminds us by the suggestive style in his prose that: "These are houses, where people lived too long, in which they died. Big cars shall arrive to remove it and throw away. It sounds strange, but there is a need to remove and throw away houses and cities to make space for the next ones, which will be once removed and

19 As Elżbieta Dutka writes: "till today the industrial landscape of Silesia with mining shafts and chimneys, horizontally and diagonally levelled pipes and transmission lines, devastated surface of land, refuse heaps, slagheaps, earthfalls, miners' housing estates and chaotic urban infrastructure is still a kind of 'showcase,' a hallmark of this place. Despite tremendous diversity of the landscape in this region, it is still perceived by wider audience in strongly conventionalized way." Dutka, "Melancholijne pejzaże," p. 80. 
thrown away too." ${ }^{20}$ The state of the post-industrial landscape is shown as a film picture by Anna Stępczak-Patyk in her short film made in Master Film Academy of Andrzej Wajda titled The End of the Street (2005), in which local architecture as well as the identity of a place are dematerialised, in this way converting into a film picture.

\section{Post-industrial landscape as an area of conflict}

In the course of time and as a result of the growth of social awareness, the intensifying process of wasting technical monuments increases the activity of citizens' resistance visible in a growing number of foundations and associations aiming at the protection of industrial heritage. At the background, ruins and debris produced at a rapid pace can be distinguished; however, the architecture preserved in satisfactory condition is now demanding a rescue or at least a creation of a documentation concerning its existence in iconic form before its final dematerialisation. An important reason of attachment to post-industrial ruins is nostalgia intensified now by late fascination with the landscape from the childhood, which let one's heart be troubled by rapid passing away and transition into debris, and also a memory of not prosperous, but vital and operative past, contrasted with the contemporary emptiness and miserable condition. Additionally, a factor that stimulates the interest in a ruin is a fact perceived in public space, namely the lack of developed rational policy of management of industrial heritage by local self-government.

That artistic approach is a distinctive feature of activity of young generation of artists - photographers with a penchant for multimedia, including Marek Stańczyk. Since 2008, he has documented the twilight of Silesian industry, capturing with the camera's eye subsequent actions of decommissioning of mines and factories. In a series of authorial films titled Made in Silesia - Industrial Landscape (2011), he managed to capture demolition of such gigantic mining facilities as buildings of former KWK (coal mine) "Andaluzja" in Piekary Śląskie or KWK "New Wirek" in Ruda Śląska, thanks to which his films, as he said, constitute today: "sole 'eyewitness' - visible - liquidation processes and changes in silesian landscape." ${ }^{21}$ Similar approach to the landscape characterises Mark Locher called

20 Andrzej Stasiuk, "I tak to się wszystko kiedyś skończy” [It will all eventually come to an end], in: Czarno-biały Śląsk [Black and White Silesia], ed. Wojciech Wilczyk (Katowice: Galeria Zderzak, Górnośląskie Centrum Kultury, 2004), p. 5.

21 Andrzej Koniakowski, "Marek Stańczyk - a panoramic gaze" (accessed 3 January 2017) http://www.koniakowski.pl/2012-3.html. 
"a photographer of a lost landscape," the author of multimedia project titled $\mathrm{Hu}$ man and Machine (2015). Those interests are evidenced by titles of his subsequent series of works: Here Things Changed, Silence of Historical Places, The End of Mine, Silesia - Returns and Goodbyes. The falling chimneys and shafts, reinforced concrete structures, machines and railway tracks are the motifs continuously present in black-and-white photographs made by the artist. What is peculiar about them is that the facilities are captured in the camera's eye at the moment of their demolition as if at the moment of letting their dying breath.

The pictures of the artists mentioned above certainly reveal in many cases surprising, monumental beauty of industrial ruins; however - maybe foremost - they capture traces of turbulent history of industry constituting a material indicator of fragile cultural identity of the region. Stańczyk treats the ruins as monuments of transitory history, which brittle and die, due to negligence and affected by deliberate, but hasty destructions activities resulting from "lack of awareness of society about historical monument and their roots." ${ }^{22}$ Locher, in turn, on the question of what interests him in ruins, replied: "That is my protest. Look what you have done. What we are losing, because of your thoughtlessness. Sometimes I understand it, because those facilities are hard to adapt, too contaminated. But is there a need to demolish most of them?"23 In this regard, both artists treat the post-industrial landscape no longer as an object of contemplation, but as a form of participation. In order to discover information about poorly accessible places, they study maps, illustrations and old photographies, and exchange the experiences with enthusiasts like them on the Internet forums, so that they could later on penetrate particular elements of landscape in an emotional way and with the embodied approach and via the camera's eye capture them before they vanish from the surface of the earth.

Conflictuality of the landscape is most noticeable in documentaries, in which the Silesia as a whole is presented in a real and metaphorical sense as a ruin. This is the case for example in the film directed by Michael Majerski The Upper Silesia Here Is Where We Meet (2013). Intertwined into the documentary film frames by

22 Małgorzata Węgiel-Wnuk, "Marek Stańczyk shows photographies that document the fall of Sienkiewicz tower former KWK Andaluzja," Dziennik Zachodni [Western Daily] 23 May 2012, (accessed 1 January 2017) http://piekaryslaskie.naszemi asto.pl/artykul/marek-stanczyk-pokazuje-zdjecia-dokumentujace-upadekwiezy, 1414243,artgal,t,id,tm.html\#521f4162c6f04995,1,3,4.

23 Tomasz Malkowski, "Marek Locher: a photographer of the lost landscape" (accessed 3 January 2017).http://www.zmienmce.fora.pl/informacje-z-myslowic,13/mareklocher-fotograf-utraconego-krajobrazu,214.html 
Marek Stańczyk and more, the whole landscape presented on the screen, not only the one connected with factories showing mining shafts and towers falling apart, but also the urban landscape constituting a gloomy hallmark of post-industrial districts, becomes one big metonymy of the Upper Silesia problem. The key issue is, according to the director, the deep crisis of the place caused not only by the ruined material industrial heritage, but also by cultural devastation being the result of breaking the ties, which in the past were connecting local culture and German tradition. The controversies of post-industrial landscape are shown, in yet another way, through the lens of Adam Sikora. In the documentary titled Corpus Christi (2005) and in a feature film created jointly with Ingmar Villqist, titled Eve (2010), is presented "dying" of the region. Destruction of the architecture of mining workers' estate is here tantamount to the collapse of local culture and identity. In the course of undergoing political transformations along with closed mines and increasing unemployment, such cultural features as working-class ethos, local customs and traditions, and lifestyle are steadily irrevocably departing, in this way leading to their eradication.

\section{Conclusions}

The post-industrial landscape as a space of accumulated problems resulting from the necessary reconfiguration of world makes us think it over. Many researchers, for example Elizabeth Mahoney, recognise it as a symbol of contemporary places infused with "difference, fragmentation, pluralism." ${ }^{24}$ In this context, taking into account only the beauty of ruins (if we want to search for such kind of aesthetics in film frames) is equivalent to the downgrading the meaning, which in fact turns out to be far more complex. Maria Popczyk indicates the limitations of post-industrial landscape only to a form resulting from the aesthetic experience, providing the landscape with values of objects with neutralised meaning, which perceived for selfless reasons constitute only decorum, a kind of expressive background. ${ }^{25}$ However, the cultural experience demonstrates deeper reflections of artists and simultaneously it can become a specific reception strategy. In both cases the post-industrial landscape becomes a document of conflict, waste,

24 Elisabeth Mahoney, "The people in parentheses: Space under pressure in the postmodern city," in: The Cinematic City, ed. David B. Clarke (London: Routledge, 1997), p. 168.

25 Maria Popczyk, "Krajobraz jako obraz" [The landscape images], in: Krajobraz kulturowy [The Cultural Landscape], eds. Beata Frydryczak and Mieszko Ciesielski (Poznań: Wydawnictwo Poznańskiego Towarzystwa Przyjaciół Nauk, 2014), p. 58-59. 
exploitation. It reveals an existential dimension of a place, emotions and experience, which accompany its reception.

Finally, we can evoke views of William J. T. Mitchell, who advocates the change in thinking about the landscape, treating it not as a noun form, but a verb form ("from a noun to the verb"). ${ }^{26}$ In this way landscape is not understood as an object that we can see or a text to read, but as a process by means of which individual and social identities can be formed. ${ }^{27}$ According to the researcher, the landscape is not a kind of art, but it is "a cultural medium."28 "Landscape is a natural scene mediated by culture. It is both represented and presented space, both a signifier and a signified, both a frame and what a frame contains, both a real place and its simulacrum, both a package and the commodity inside the package."29 Such a view of post-industrial landscape captured in "Silesia cinema" becomes a space, of which penetration can provide us with interesting conclusions going beyond the issues concerning poetics of picture, styles and artistic conventions, which refer to life itself - transforming locality and identity of a place.

\section{Bibliography}

Baudrillard, Jean. Toward a Political Economy of the Sign. St. Louis: Telos Press, 1981.

Bell, Daniel. The Coming of a Post-Industrial Society. New York: Basic Books, 1974.

Dutka, Elżbieta. "Melancholijne pejzaże Śląska" [Melancholic landscapes of Silesia]. Białystok Literature Studies, Vol. 3, 2012, pp. 79-96.

Edensor, Tim. Industrial Ruins. Spaces, Aesthetics and Materiality. Oxford and New York: Berg, 2005.

Fiderkiewicz, Maria. Ślascy pariasi pędzla i dtuta [Silesian Pariahs of Brush and Chisel]. Katowice: Muzeum Śląskie, 1994.

Lewandowski, Jan F. Silesian Cinema. Katowice: Wydawnictwo “Śląsk”, 2012.

Mahoney, Elisabeth. "The people in parentheses: Space under pressure in the postmodern city." In: The Cinematic City, ed. David B. Clarke. London: Routledge, 1997, pp. 168-185.

Mitchell, William J. T, ed. Landscape and Power. Chicago: University of Chicago Press, 2002.

26 William J. T. Mitchell, "Introduction," in: Landscape and Power, ed. William J. T. Mitchell (Chicago: University of Chicago Press, 2002), p. 1.

27 Mitchell, "Introduction."

28 See Mitchell, "Introduction," p. 2.

29 Mitchell, "Landscape and Power," p. 5. 
Nitka, Małgorzata. "Pokłady wyobraźni: poetyka przestrzeni industrialnej" [Layers of imagination: Poetics of industrial space]. In: Przestrzeń w kulturze i literaturze [Space in Culture and Literature], ed. Ewa Borkowska. Katowice: Wydawnictwo Uniwersytetu Śląskiego, 2006, pp. 42-54.

Pokropek, Marian. "Śląska plastyka nieprofesjonalna - wyjątkowa kolekcja" [Silesian unprofessional artistic creativity - Unique collection]. In: Twórcy intuicyjni z kolekcji Barwy Ślaska [Intuitive Artists from the Collection Colours of Silesia], ed. Stanisław G. Trefoń. Ruda Śląska: Stowarzyszenie "Barwy Sląska," 2015, pp. 14-17.

Popczyk, Maria. "Krajobraz jako obraz" [The landscape images]. In: Krajobraz kulturowy [The Cultural Landscape], eds. Beata Frydryczak and Mieszko Ciesielski. Poznanń: Wydawnictwo Poznańskiego Towarzystwa Przyjaciół Nauk, 2014, pp. 55-64.

Sontag, Susan. On Photography. New York: Rosetta Books, 2005.

Stasiuk, Andrzej. "I tak to się wszystko kiedyś skończy" [It will all eventually come to an end]. In: Czarno-biały Slask [Black and White Silesia], ed. Wojciech Wilczyk. Katowice: Galeria Zderzak, Górnośląskie Centrum Kultury, 2004, p. 5-6.

\section{Online sources}

Węgiel-Wnuk, Małgorzata. "Marek Stańczyk shows photographies that document the fall of Sienkiewicz tower former KWK Andaluzja."Dziennik Zachodni [Western Daily] 23 May 2012. http://piekaryslaskie.naszemiasto.pl/artykul/marek-stanczyk-pokazuje-zdjecia-dokumentujace-upadekwiezy, 1414243, artgal,t,id,tm.html\#521f4162c6f04995,1,3,4 (Accessed 3 January 2017).

Malkowski, Tomasz. "Marek Locher: A photographer of the lost landscape." http:// www.zmienmce.fora.pl/informacje-z-myslowic, 13/marek-locher-fotografutraconego-krajobrazu,214.html (Accessed 3 January 2017).

Koniakowski, Andrzej. "Marek Stańczyk - a panoramic gaze." http://www.koniakowski.pl/2012-3.html (Accessed 3 January 2017). 


\title{
Marta Stańczyk \\ Instytut Sztuk Audiowizualnych \\ Uniwersytet Jagielloński, Poland \\ 19. Once upon a time there used to live a people... Neighborhooders and The Heritage as fairy tales about the Polish "excluded"
}

\begin{abstract}
Polish society still carries its wounds after years of communism and political system transformation as the introduction of capitalism brutally threw out all the people who were passive in their society and their own life under the Polish Peoples' Republic into the social margin. They were neglected not only in the social-political sphere but also in the cultural one. In Polish films, only their decay or glorification was shown, which increased the feeling of exclusion. This situation has been illustrated by the films Neighborhooders (2014, Grzegorz Królikiewicz) and The Heritage (2011, Andrzej Barański). Both film directors are looking for a new language of expression to portray the fate of a lower class they transcend the discourse of social engagement and instead of using the language of Cepeliada and folklore, they create stories bordering on fairy tales.
\end{abstract}

Keywords: Neighborhooders, The Heritage, Grzegorz Królikiewicz, Andrzej Barański, Andrzej Leder, lower class, exclusion, identity, film language, Polish cinema

Polish society still carries its wounds after many historical turbulences, many of which occurred only in the twentieth century: occupation by Nazi Germany during the Second World War, years of communism and the political system transformation, and the introduction of capitalism which brutally threw out into the social margin all the people who were passive in their society and their own life under the Polish Peoples' Republic (Polska Rzeczpospolita Ludowa - PRL). The data collected by the Central Statistical Office (Główny Urząd Statystyczny - GUS) shows that $12 \%$ of the Polish population in 2013-2014 were living below the national poverty threshold and 7\% were living in absolute poverty. The emasculation of a lower class in Poland is one of the main aftermaths of the twentieth century. Poverty and the lack of social and political meaning are not the only form of marginalization. The reluctance to discuss social discourse as class discourse together with a strong stratification of society caused that the lower class was rarely discussed, which additionally reinforced their exclusion. 
It was neglected not only in the social-political sphere but also in the cultural one. In Polish films, only its decay was shown which increased the feeling of exclusion. The Polish "excluded's" mise-en-scène depicts pathology with plenitude of vodka, crime and a downfall: a countryside is full of dangerous rednecks with axes (i.e. Wojciech Smarzowski's The Wedding/Wesele [2004] or The Dark House/ Dom zły [2009]) and panel buildings (simple and cheap tenement houses built for common people) are the synecdoche of lost hopes (i.e. Robert Gliński's Hi, Tereska/Cześć, Tereska [2001] or Tomasz Wasilewski’s United States of Love/Zjednoczone stany miłości [2016]). On the other hand, Polish contemporary cinema reveals a modernist tradition in which - before heavy post-war industrialization - villagers are glorified. The period known as Young Poland used to be enthralled by country folklore, people's simplicity and authenticity. One of the main representatives of this tradition is Jan Jakub Kolski (Johnnie the Aquarius/Jańcio Wodnik [1993] or History of Cinema in Popielawy/Historia kina w Popielawach [1998]). Each of these cinematic tendencies is clichéd and ahistorical, therefore apolitical and disregarding toward the identity of the lower class, but recent years have been showing a possible evolution. Marcin Wrona meditated on Polish memory in Demon (2015) and Agnieszka Smoczyńska explored Polish legends on political transformation's background in The Lure/Córki dancingu (2015). But Grzegorz Królikiewicz's Neighborhooders/Sąsiady (2014) and Andrzej Barański's The Heritage/Księstwo (2011) remain the most profound and diversified reflection on the Polish lower class and - what is more important - constitute a bold, maybe even blatant attempt to create a lower class mythology.

The first film narrative concentrates on the inhabitants in one of the tenement houses in Łódź, and the other film deals with the story of a young man who attempts to escape from a village to a city. Both film directors are looking for a new language of expression to portray the fate of the lower class - they transcend the discourse of social engagement and instead of using the language of Cepeliada and folklore, they create stories bordering on fairy tales. Królikiewicz and Barański formed the poetic language that includes the grotesque, mitologization of discourse, universalization of space and the use of anachronistic narrative formulas (sylves, fairy tales and ballads) in order to appreciate underprivileged groups.

\section{A poor Pole looks at the ghetto}

It is not possible to start the case studies of films mentioned above before their contextualization. As Marek Smolen pointed out, political transformation in Poland had many social effects - frustration, a sense of grievance and helplessness, social isolation, addictions, increased pathological conduct, delinquency, family 
dysfunctions, a division into Poland $\mathrm{A}$ and $\mathrm{B}$, and so on - which are derived from unemployment and impoverishment, above all. ${ }^{1}$ Although his study correctly elaborates on the side effects of the process of decommunization, democratization and transformation into market economy, it seems shortsighted and dismissive toward people's psyche, or rather disadvantaged cultural memory that has lost its social operativeness. As Jan Assmann wrote, memory constitutes community "just as the art of memory pertains to learning, so does the culture of recollection to planning and hope, i.e. to staking out social horizons of meaning and time". But what happens when this collective memory is blocked and superseded as in the case of the Polish lower class? And what causes this process? These are the questions which Andrzej Leder tried to answer in Dreamt Revolution.

In the beginning of his book Leder quotes Charles Taylor considering social imaginaries as the foundation of social meaning. But they are annihilated during periods of a downfall when we can observe the catastrophe of a symbolical field. ${ }^{3}$ Author's underlying thesis is that we are still living in Folwark (grange buildings) with its prevalent serfdom relations and worldview, which is caused by the fact that Polish modernization was mediated by German and Russian oppressors and therefore rejected. For Leder, the auto-destructiveness of the lower class and the cosmopolitanism of a middle class in Poland are not the heritage of occupation or transformation, but of serfdom and "dreamt revolution" from 1939 to 1956. The delegitimization of social order did not bring any alternative so the "excluded" fed themselves with perceived, ressentiment-based grievances. ${ }^{4}$ In 1939, Soviets and Nazi Germans invaded Poland - that disaster revealed hidden desires and started revolutionary operations. Polish society transformed but without subjective contribution.

Above all, a previous hierarchy was fractured after 1939 - a sense of humiliation was predominant but affected essentially pre-war elites and the middle class. The townsmen group's existence was problematic due to its members' ethnicity: there were mostly Jews. Their presence in pre-war Poland had already raised controversies and inspired a strong antisemitism even in official political statements. This public

1 See: Marek Smoleń, „Społeczne skutki procesów transformacji gospodarczej w wymiarze lokalnym," Nierówności społeczne a wzrost gospodarczy. Czesść II - Racjonalizacja i globalizacja, vol. 9 (2006), pp. 283-296.

2 Jan Assman, "Cultural Memory: Script, Recollection, and Political Identity in Early Civilizations," Historiography East and West, vol. 1, no. 2 (2003), p. 159.

3 See: Andrzej Leder, Prześniona rewolucja. Ćwiczenia z logiki historycznej (Warszawa: Wydawnictwo Krytyki Politycznej 2014), pp. 10-11.

4 See: Leder, Prześniona rewolucja, pp. 35-36. 
mood prepared a ground for Nazi German crimes toward Jewish nation in Poland these atrocities often provoked mixed feelings and even moved some Poles into a non-coerced participation in Holocaust (i.e. the massacre in Jedwabne). After 1945, Poles took Jewish place in society, creating new social stratification and ethnically Polish bourgeoisie on genocide. ${ }^{5}$ For Leder, this is the reason why contemporary middle class has problems with its identity and history - a morally dubious heritage caused the process of a psychological repression (understood in the frame of collective memory). The descendants of serfs capitalized opportunity for social and political advancement but denied it - the next generations were willingly (and artificially) creating their history on noble roots. No one could call them impostors because of the Polish landed gentry's extermination. Soviets encouraged peasants to rebel and take revenge on lords, which they did not only for materialistic motives, but also to save their personal integrity and reclaim their dignity after centuries of contempt. However, common people did not identify themselves with revolution and its goals, which came from within and therefore they opened to the defense mechanism of regression: "unstable and lacking any point of reference (connected with pre-war hierarchies) Polish imaginary retreated to simpler and more directly affectionate forms" 6 - i.e. miraculous religion. The lower class emphasizes the division between Good and Evil, hence their patriotism and national identity involve primitive "we-they" dialectics.

Dreamt Revolution is a historical elaboration on Polish memory, postmemory and mentality based on them - or maybe on their lack. "People cannot act as subjects and build any community because of their inability to recollect." The lower class has an indolent mentality, still living in a power relations created in Folwarks. The absence of social influence goes hand in hand with the lack of any responsibility. This social group lives in the present, reluctant to critical thinking, dialogue, or reaching a consensus. Hence years of Sovietization did not change Polish citizen into conformist homo sovieticus but only amplified residues resulting from serfdom. We can find critical examination of traditional class roles in Polish society in Witold Gombrowicz's Ferdydurke, elaborate discourse on this ambivalent heritage in In the Name of Jakub S., controversial spectacle by Pawel Demirski and Monika Strzępka ${ }^{8}$, and in mythopoetic films by Andrzej Barański

5 See: Leder, Prześniona rewolucja, p. 88.

6 Leder, Prześniona rewolucja, p. 152.

7 Leder, Prześniona rewolucja, p. 94.

8 See: Joanna Derkaczew, “W imię Jakuba S.' Nie wstydźcie się słomy z butów," Gazeta Wyborcza, 10.12.2011: 19 Feb. 2017 wyborcza.pl/1,75410,10791500,_W_imie_ Jakuba_S Nie_wstydzcie_sie_slomy_z_butow.html. 
and Grzegorz Królikiewicz. Both film directors use the notion of myth, fairy tale or legend in order to invent a new point of reference for rumination and for creating new identity. As Jacques Le Goff noticed, previously submissive societies should make an effort to define themselves through rediscovery and acknowledgement of their past, because memory "is an essential element of... individual or collective identity, the feverish and anxious quest for which is today one of the fundamental activities of individuals and societies."

\section{The Heritage and delusive social mobility}

Writing about Polish cinema, Natasza Korczarowska coined the concept of "private homelands" as a mythological frame of reference for individuals. It is a space based on myth and symbol, subjective reality structured by repetitions and which lasts in somehow constant order. Tadeusz Konwicki, Andrzej Kondratiuk, and Jan Jakub Kolski - to whom we may add Andrzej Jakimowski or Lech Majewski share convictions about memory's function: "Memory - emotional memory which is also the record of the most painful experiences - is the only way for restoring a sense of meaning and protecting from a nihilist urge." ${ }^{10}$ Królikiewicz and Barański are convinced of that but they depict the reverse of these worlds. In their universe the exact notion of a "homeland" is ambivalent, their characters are not connected with the world, but they exist as monads, the core of their identity is a sense of being excluded, not a national or local tradition. Both film directors try to explore this limbo and construct its mythology and memory.

In the first sequence of The Heritage, young main character, Zbyszek Pasternak, is building a mouse trap (it can be interpreted either as a reference to the Polish legend about king Popiel or as a metaphor of entrapment) when his drunk father comes back to the house and starts his monologue,

You have to remember that we descended from powerful prince of Vistulans who is described in Vita Cirilli. Do you understand? Unfortunately, our descendants had begun marrying subaltern women and now we, the eagles, have to live among the hens. I hope you will help our family to regain our eagle power. I must teach you how to fly. The thing you did today, you know - this mouse trap, was something extraordinary. I am sure it is a sign! You will be a great lord someday and I will guard a new dynasty. But first you have to get rid of your childhood.

9 Jacques Le Goff, History and Memory (New York: Columbia University Press, 1992), p. 98.

10 Natasza Korczarowska, Ojczyzny prywatne. Mitologia przestrzeni prywatności w filmach Tadeusza Konwickiego, Jana Jakuba Kolskiego, Andrzeja Kondratiuka (Kraków: Rabid, 2007), p. 17. 
After these words, father cuts his son's hair and destroys his old baby carriage initiating a rite of passage. This sequence shows in a grotesque way a misconception leading to megalomania and fake identity. Simultaneously, it is a synecdoche of striving for this identity and political meaning.

The central part of this fairy tale is painful in depicting consequences of this fake mythology. Zbyszek descends into a deep sense of humiliation and realizes his failure. He lives in Lublin where he studies law (he fails at exams and is expelled from the university), starves, works as a stockman, and commits petty crimes because he has lost a chance for a career in football after sports injury. When he comes back to his village, the local residents are very critical of his person as a highbrow and ungrateful "runaway" who has left his mother alone working in the fields as an agricultural laborer. Zbyszek is torn between village and city but belongs nowhere. The film includes loosely connected sequences from which his opportunism and copying father's auto-destructive patterns emerge. He is involved in a fight between two villages; an embarrassing sex intercourse; depressing work in a sawmill, whose owner employs mostly alcoholics; and in situations when he is a victim of constant jibes. Moreover, a sense of humiliation and being disadvantaged is a common feeling for all local people. It is especially emphasized in the sequence of village dogs being euthanized by town's people who are welleducated so they can dominate the discourse. One of the last scenes depicts a roadblock - villagers protest against their situation, lack of social meaning and poverty, but simultaneously they show the anomaly of a social cohesion: "You cannot ignore Polish peasants anymore. We do not give a fuck that other people also have problems. We must think only about ourselves". So they are - they pass delayed trucks when drivers give them some vodka, shut down the roadblock and run away with fruits picked up from a lorry. A rebellion ends and they return to their purgatory with an ad hoc trophy.

Although villagers are shown mostly as auto-destructive, grotesque, disorganized, unable of consistent action, and even ridiculous, Barański does not divest them of their dignity. The province in The Heritage is claustrophobic, unattractive and coarse, maybe even doomed. However, the film director looks at it in search of glimpses of hope and dignity. He has a compassion for this entrapment. In the last scene, father and son wander with poppy seeds for the monastery, but they lose them while climbing up the hill. Socio-political reality plunges the Polish province into a downfall, but in this metaphorical sequence Barański creates an elegy for the "excluded". 


\section{Neighborhooders and (a) film dialect(s)}

Królikiewicz's film compounds this sense of entrapment by means of an experimental film language. The damped, narrow apartments with poor wall units do not signify the provisional character of their lives - although film director depicts a rather deterministic vision, he connects it with the occurrence of small epiphanies and liberations. Action of the film takes place in Łódźs tenements called famuly. Their inhabitants are depicted in a complex way - they are often agonized and desperate by their exclusion, poverty and overwhelming violence, but these degraded human beings also degrade others. They are not able to communicate with the outside world and they are not self-conscious. Królikiewicz shows their routine - preparing for Christmas Eve, gossiping, quarrels, struggling for rudimentary supplies, and so on in ten episodes, which seem apocalyptic and poetic simultaneously. They isolate themselves from the outside world but the society is not eager to acknowledge their demotic component: as in the sequence with an honored doctor who liquidates hospital in order to stop "worshipping autochthons" and "feeding bloodsuckers". He responds to an older, compassionate professor protesting against the cruelty of this shutdown: "Everyone here is so ill that we have not got anyone to treat. Medicine is not a propaganda". Then he does not want to help a man with a heart attack, explaining that he is dirty and must sober up.

Królikiewicz is one of the most consistent and radical Polish film directors interested in the lower class and the process of exclusion. In his debut, Through and Through/Na wylot (1973) he depicted a young, poor, married couple that decides to kill an older couple in an act of social revenge and as a compensation for years of injustices. In another movie, The Case of Bronek Pekosinski/Przypadek Pekosińskiego (1993), his "man without qualities" is a metaphor of historical determinism influencing particularly the poorest. Królikiewicz is fascinated by simple men, "men from the cellar" - they are unattractive, unreasonable, and untalented, but he depicts their inner world: emotions, struggling and feelings. His characters are not only a matter and the set of socio-political determinants but also spiritual beings. In Neighborhooders, they get a narrative and a form appropriate to coin their mythology. As Krzysztof Świrek wrote in his review, "According to stereotyped thinking, Królikiewicz's characters do not do anything, exist in a void, practically do not live. They sit on window sill all day, quarrel ceaselessly without any reasonable cause, and stand next to their tenements perpetually. They only pretend to have any occupation. But in Neighborhooders their life unveils its own language: recurring motives, peculiar rituals and obsessions. It is complex to the extent of incomprehensiveness to the outsiders". ${ }^{11}$

11 Krzysztof Świrek, „Sąsiady“ (review), Kino, vol. 3, 2015, pp. 68-69. 
A film language, or rather a film dialect, created by Królikiewicz and Barański is engulfed in their idiosyncrasies, but there are many common elements: a high level of mythologization, the use of grotesque, an emphasis on individual-society relations, a time deformation, a space universalization, segmented structures, repetitions and anachronistic narrative formulas. The Heritage combines three language registers: local dialect, which is predominant in Zbyszek's village, literary language absorbed by the character, and chivalric stylization, which can be called an artificial language of Zbyszek's aspirations. This heterogeneity is transferred to film form in a holistic way. The Heritage resembles rural drawn-out story in its dramaturgy: the plot develops from one anecdote to another as neighbors pass rumors next to fences; form creates a distance due to Jacek Petrycki's black-and-white photography but it is "ornamented" by tawdry music and mannerism typical for amateur theaters - and in the folk art's simplicity. Neighborhooders are more avant-garde, subversive and mythopoetic. Królikiewicz replaces cinema of social commitment with its interventional tone with surrealism, anti-aesthetic, onirism, grotesque, and hyperbolic imaginary. The film lacks coherence - poetic dialogues are interrupted by sporadic introspections, Marek Dyjak's drank-through voice is juxtaposed with Pergolesi's Salve Regina, a celebrity body-builder plays a priest; plants on wife's and husband's graves - as on Tristan's and Iseult's - intertwine with each other, the sardonic irony mingles with lyricism, beautiful ghosts accompany hideous "moral authorities", and two tenements approach each other closing the exit to the outside world where only Lewis Carroll's white rabbit can force his way through.

The Heritage and Neighborhooders create new folk archetypes. They are interested in the lower class but not in its potential pathologies, apathy or passivity. Królikiewicz and Barański re-enact the exact notion of "a people" and create an alternative form for it. Both films tell stories about social conflicts and the reality of the "excluded" in a way close to magic realism's imaginary. Either in the provinces (Barański) or in the city (Królikiewicz) - although a people's psyche still can be marginalized - it gains a possibility of ingraining itself and creating its own identity through storytelling.

\section{Bibliography}

Assmann, Jan. "Cultural Memory: Script, Recollection, and Political Identity in Early Civilizations." Historiography East and West, Vol. 1, No. 2, 2003, pp. 154-177.

Derkaczew, Joanna. “W imię Jakuba S.' Nie wstydźcie się słomy z butów." Gazeta Wyborcza, 10.12.2011,No.287,p.12.http://wyborcza.pl/1,75410,10791500,_W_ imie_Jakuba_S__Nie_wstydzcie_sie_slomy_z_butow.html (19 Feb. 2017). 
Korczarowska, Natasza. Ojczyzny prywatne. Mitologia przestrzeni prywatności w filmach Tadeusza Konwickiego, Jana Jakuba Kolskiego, Andrzeja Kondratiuka. Kraków: Rabid, 2007.

Le Goff, Jacques. History and Memory. New York: Columbia University Press, 1992.

Leder, Andrzej. Prześniona rewolucja. Ćwiczenia z logiki historycznej. Warszawa: Wydawnictwo Krytyki Politycznej, 2014.

Smoleń, Marek. "Społeczne skutki procesów transformacji gospodarczej w wymiarze lokalnym." Nierówności społeczne a wzrost gospodarczy. Część II Racjonalizacja i globalizacja, Vol. 9, 2006, pp. 283-296.

Świrek, Krzysztof. “Sąsiady” (review). Kino, Vol. 3, 2015, pp. 68-69. 
